\title{
Der Zauberberg in philosophical, psychological, and sociological contexts: an intertextual reading of Thomas Mann
}

by

Jessica Anne Macauley

\begin{abstract}
A thesis
submitted to the Victoria University of Wellington in fulfilment of the requirements for the degree of Doctor of Philosophy
\end{abstract}

Victoria University of Wellington 2015 


\begin{abstract}
Life, death, disease and Eros are themes of universal relevance that have been addressed in works of science, philosophy, literature and art throughout recorded human history. In the early $20^{\text {th }}$ century, the unprecedented scale of human extermination during World War I necessitated the adaptation of old ideas to a new reality. This is manifest in the work of the German author Thomas Mann, whose developing ideas on life, death, disease and Eros are clearly apparent in his novel Der Zauberberg (1913-1924).

Der Zauberberg is set at a Swiss tuberculosis sanatorium in the years leading up to World War I. The main protagonist, Hans Castorp, arrives at the sanatorium as a visitor and is subsequently diagnosed with tuberculosis. During his sanatorium stay, Castorp comes into contact with three pedagogic figures: Ludovico Settembrini, Leo Naphta and Mynheer Peeperkorn. These men represent various attitudes towards life, death, disease and Eros. The humanist Settembrini, for example, affirms life but is repulsed by Eros, disease and death; the Jesuit ascetic Naphta glorifies erotic suffering and death while denying life, and the coffee magnate Peeperkorn celebrates life and Eros - yet to a pathological extent. My thesis follows the dialogic clash between the views of these pedagogues, as well as their influence on Hans Castorp, and is divided into sections that relate these views to their sociological implications. After examining the nature of death, life and disease within the novel, I relate these to the novel's portrayal of society. I follow this with an investigation of the connection between death, life, disease and Eros, and conclude by examining these themes within their sociological context in Der Zauberberg.

The conceptions of life, death, disease and Eros in Der Zauberberg are largely borrowed, following Thomas Mann's creative technique of "Montage", which allowed him to incorporate themes, concepts, paraphrased passages and quotations from other thinkers into his own work. These borrowed ideas create a complexity of textual relationships that corresponds to the theory of intertextuality; accordingly, my thesis examines Thomas Mann's novel from an intertextual angle. Although Der Zauberberg has been the subject of intensive, source-critical study, the newer field of intertextual theory has largely been ignored, notable exceptions being the analyses of Thomas Mann's works by Barbara Beßlich, Claudia Gremler, Michael Maar and Franziska Schößler. These scholars have
\end{abstract}


narrowed the original, prohibitively wide scope of intertextual theory to enable intertextual analysis of individual texts. Following their example, I limit my definition of the intertext to philosophy, sociology and psychology, specifically to the works of the philosopher-poet Novalis (Friedrich von Hardenberg), of the philosophers and sociologists Arthur Schopenhauer and Friedrich Nietzsche, and of the psychologist and sociologist Sigmund Freud. My analysis of Der Zauberberg identifies connections to the intertexts within the novel, and examines how clearly these are presented and what form they take. Most importantly, I investigate the heuristic impact of the novel's intertextuality, that is, how the intertextual relationships in Der Zauberberg influence the reader's interpretation of both the nature of life, death, disease and Eros, and their effect on culture in the novel. 


\section{Acknowledgements}

I would like to express my gratitude to my primary and secondary supervisors, Dr Monica Tempian and Dr Margaret Sutherland. Thanks also to Buddenbrook Haus in Lübeck, for

granting me access to their library, as well as to Anya Maule, Maria Polaczuk, and Jörg Kluge. Finally, a big thank you to my children Mia and Phoebe, throughout whose entire lives I have been, if not writing, then thinking about my thesis. 


\section{Table of contents}

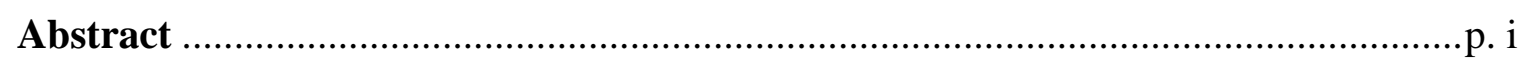

Acknowledgements …................................................................................. p. iii

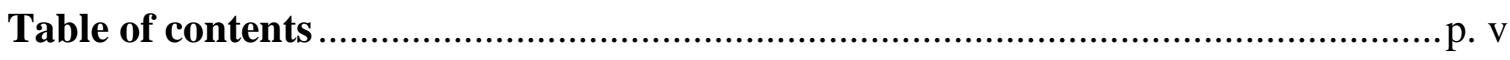

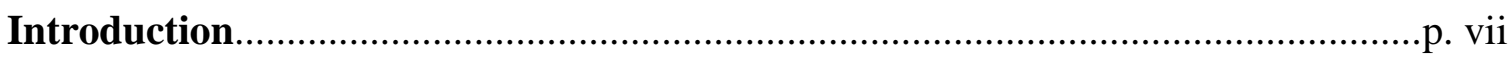

\section{Chapter 1: Design and intention}

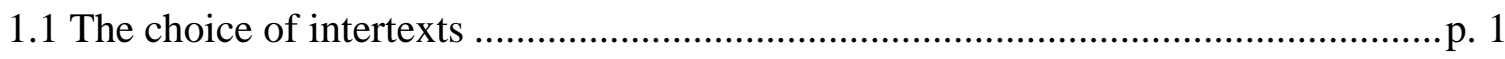

1.2 Der Zauberberg and the work of Novalis, Schopenhauer, Nietzsche and Freud: the position of this study in relation to existing source-critical scholarship ....................... 6

1.3 Models of intertextuality: text and intertext .............................................. 11

1.4 Author, reader, text: the origin of meaning production ..................................p. 16

\section{Chapter 2: Death and life on the mountain}

2.1 The social repression of death ................................................................ 21

2.2 Views of death: Christian versus atheist....................................................p. 29

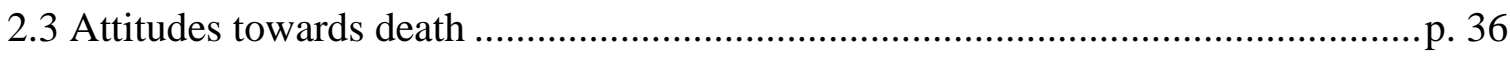

2.4 The affirmation of death and the devaluation of life ........................................ 41

2.5 The glorification of death as release …....................................................... p. 49

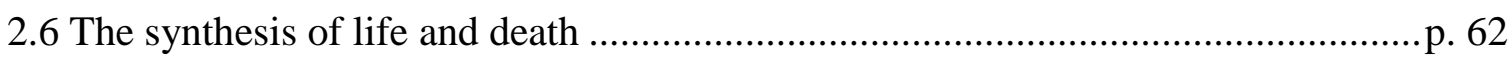

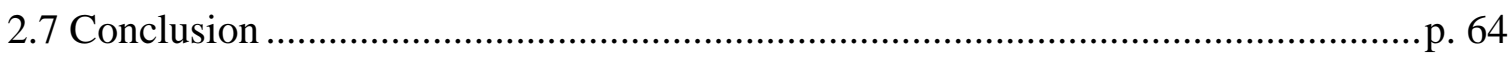

\section{Chapter 3: Disease and life}

3.1 The nature of life: receptivity to stimuli ...................................................... 67

3.2 Stimuli, determinism and heredity .......................................................... 73

3.3 Health, disease and the organism............................................................... 80

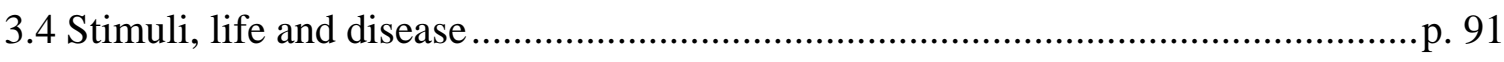

3.5 The interrelation of life, mind and disease ...................................................p. 98 


\section{Chapter 4: Disease and culture}

4.1 The environmental causes of disease ........................................................p. 107

4.2 Lethargy and boredom ................................................................... 108

4.3 Boredom, time and entertainment........................................................p. 114

4.4 Entertainment and intoxication............................................................p. 119

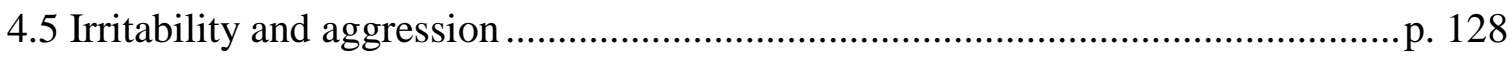

4.6 The combination of lethargy and irritability ............................................... 135

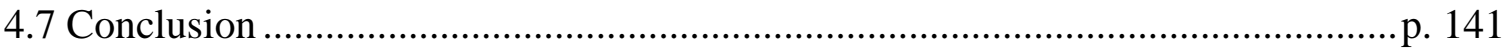

\section{Chapter 5: Life, Eros, death and disease}

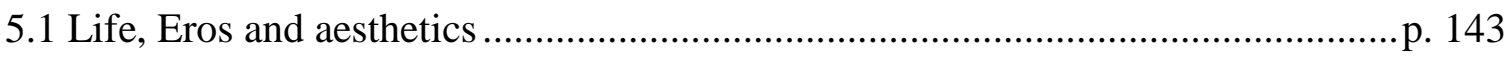

5.2 The nature of Eros: stimuli and the body.................................................. 154

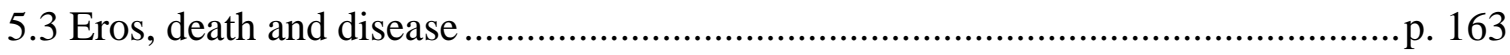

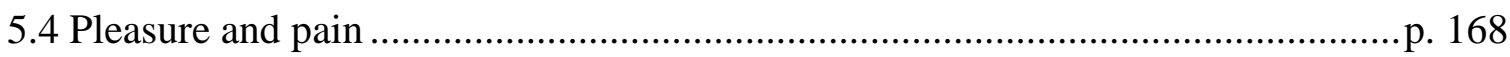

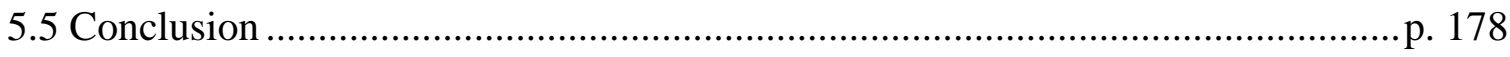

\section{Chapter 6: Culture, Eros, death and disease}

6.1 Culture versus nature: morality, Eros and disease ......................................p. 181

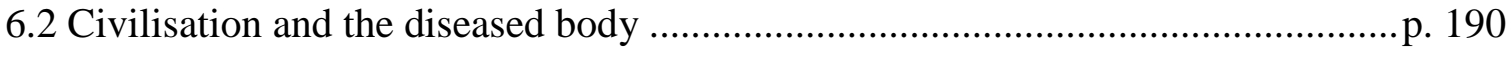

6.3 Erotic freedom, decadence and gender ...................................................... 196

6.4 The power of immoral lust and disease over moral life ...................................p. 204

6.5 Synthesis or mediation? Eros, disease and humanity ..................................... 211

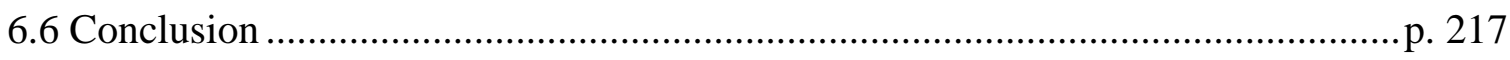

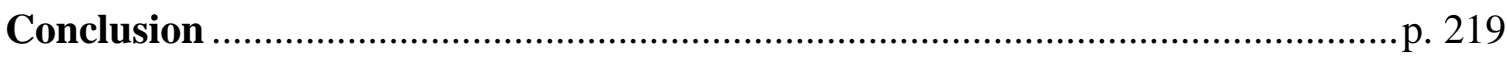

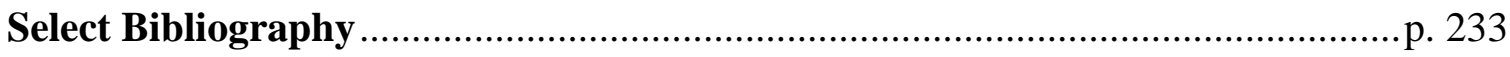




\section{Introduction}

Thomas Mann was one of the most influential German novelists of the $20^{\text {th }}$ century. ${ }^{1}$ Born in Lübeck on 6 June 1875, Mann grew up in an atypical household marked by a contrast between the upper-middle-class German milieu of his merchant father and the ideals of his artistic Brazilian-German mother. ${ }^{2}$ This distinction was reflected throughout Thomas Mann's literary career as a tension between the desire to be accepted by the public (" $[\mathrm{m}] \mathrm{ich}$ verlangt auch nach den Dummen") ${ }^{3}$ and a sense of artistic exclusiveness. ${ }^{4}$ Mann's aloofness from his social milieu arguably contributed to his developing critical interest in culture during the first quarter of the $20^{\text {th }}$ century. ${ }^{5}$ This sociological interest was inextricably linked to Mann's reading of philosophy and psychology, and these three disciplines together profoundly influenced Mann's world view, which changed following the experience of World War I from conservative support of the monarchy of Wilhelm II,

\footnotetext{
${ }^{1}$ C. Heinze. Identität und Geschichte in Autobiographischen Lebensrekonstruktionen. Jüdische und nichtjüdische Vergangenheitsbearbeitungen in Ost- und Westdeustschland. Wiesbaden: Verlag für Sozialwissenschaften, 2009, pp. 516-17; Adolf Muschg and Mario Simmel quoted in H. Koopmann. "Thomas Mann”, in H. Steinecke (ed.). Deutsche Dichter des 20. Jahrhunderts. Berlin: Erich Schmidt Verlag, 1994, pp. 135-57, here, p. 135; H. Koopmann. "Vorwort", in H. Koopmann (ed.). Thomas Mann Handbuch. Frankfurt am Main: S. Fischer Verlag, 2005, pp. XIII-XV, here, p. XIII; M. Reich-Ranicki. Thomas Mann und die Seinen. Stuttgart: Deutsche Verlags-Anstalt, 1988, pp. 11-20.

2 Mann. "Lebensabriß" (1930), in P. Mendelssohn (ed.). Thomas Mann. Gesammelte Werke, vol. XI. Frankfurt am Main: S. Fischer Verlag, 1984, pp. 99-100. Thomas Mann's father himself embodied this contrast: "[Ein] Geschäftsmann, praktisch, aber mit Neigung zur Kunst" (Mann 21, p. 58). Thomas Mann describes this combination in the Betrachtungen eines Unpolitischen (in reference to Nietzsche) as a "doppelte Optik" (Mann 13.1, p. 119). Such references in this thesis to Mann 1-38 concern the edition of Thomas Mann's complete works edited by H. Detering, E. Heftrich, H. Kurzke, T. J. Reed, T. Sprecher, H. R. Vaget and R. Wimmer. Thomas Mann. Große Kommentierte Frankfurter Ausgabe. Werke - BriefeTagebücher. Frankfurt am Main: S. Fischer Verlag, 2002. This edition is to date incomplete; works by Thomas Mann not included within the existing volumes are referenced in this thesis using older editions of Thomas Mann's work. These include: P. Mendelssohn (ed.). Thomas Mann. Gesammelte Werke, vol. XI, op. cit.; E. Mann (ed.). Thomas Mann Briefe, vols. I-III. Frankfurt am Main: S. Fischer Verlag, 1978, and Hans Bürgin (ed.). Thomas Mann. Schriften und Reden zur Literatur, Kunst und Philosophie, vol. 2. Frankfurt am Main: S. Fischer Verlag, 1968.

${ }^{3}$ Letter to Hermann Hesse of 1 April 1910, in Mann 21, p. 448.

${ }^{4}$ Hermann Kurzke argues that Thomas Mann's perception of difference followed his semi-aristocratic status and financial independence (H. Kurzke. Thomas Mann: Epoche - Werk - Wirkung. München: C. H. Beck, 1997, p. 28).

${ }^{5}$ Ibid., p. 27; Mann 13.1, p. 14.
} 
glorification of war and of social hierarchies, to a focus on humanity, peace, democracy and the individual. ${ }^{6}$

Thomas Mann's changing sociological, philosophical and psychological views are evident in his novel Der Zauberberg, which he began in 1913 and finally published in November 1924. Initial work on the novel was interrupted by the outbreak of World War I, when Mann turned his attention to the Betrachtungen eines Unpolitischen (1915-1918). As he explained in a letter of 25 March 1917: "Die Betrachtungen muß ich nur deshalb schreiben, weil infolge des Krieges der Roman [Der Zauberberg] sonst intellektuell unerträglich überlastet worden wäre". ${ }^{7}$ Mann resumed work on Der Zauberberg in 1919, ${ }^{8}$ interrupting the novel a further three times to compose the essays "Goethe und Tolstoi" (1921) and "Okkulte Erlebnisse" (1923), as well as the speech "Von deutscher Republik" (1922). ${ }^{9}$ These satellite works of non-fiction reflect the development of Thomas Mann's ideas: the Betrachtungen show Mann's support for Wilhelm II and of war, whereas "Goethe und Tolstoi" and "Von deutscher Republik" reflect Mann's later endorsement of democracy and affirmation of life. ${ }^{10}$ The entire trajectory of these ideas, however, is best demonstrated by Der Zauberberg: following its 11-year genesis from 1913 to 1924, the novel presents the reader with a unique spectrum of sociological, philosophical and psychological thought.

Der Zauberberg is set at a tuberculosis sanatorium high in the Swiss Alps, and portrays a social microcosm clearly intended to reflect pre-World War I European society (the novel concludes with the outbreak of war). The principal character, Hans Castorp, travels from Hamburg to the sanatorium as a visitor; however, he joins the ranks of the diseased when he is diagnosed with tuberculosis soon after his arrival. During his seven-

\footnotetext{
${ }^{6}$ Mann 15.1, pp. 514-59; see also H. Koopmann. "Die Lehren des Zauberbergs", in T. Sprecher (ed.). Das Zauberberg Symposium. Thomas-Mann-Studien, vol. 11. Frankfurt am Main: Vittorio Klostermann Verlag, 1995, pp. 59-80, here, p. 73.

${ }^{7}$ Mann 22, p. 180. Also quoted in H. Wysling. "Der Zauberberg”, in H. Koopmann (ed.). Thomas Mann Handbuch, op. cit., pp. 397-422, here, p. 398. See also Mann. "Einführung in den Zauberberg”, in H. Bürgin (ed.). Thomas Mann. Schriften und Reden zur Literatur, Kunst und Philosophie, vol. 2, op. cit., pp. 326-37, here, p. 331.

${ }^{8}$ H. Wysling. "Der Zauberberg”, op. cit., p. 398.

${ }^{9}$ On 10 June 1923, Thomas Mann wrote to Ernst Bertram, announcing: "Ich habe das verschleppte RomanUntier [Der Zauberberg] [...] wieder aufgenommen” (Mann 22, p. 485).

${ }^{10}$ Mann later described these small works as "geistige Schößlinge und Ableger des großen laufenden Romans [Der Zauberberg]" (Mann. "Einführung in den Zauberberg”, op. cit., p. 332).
} 
year residence at the sanatorium, Castorp is exposed to a wide range of ideas as he is brought into contact with three pedagogic figures: the life-affirming democrat and humanist Ludovico Settembrini; the communist Jesuit affirmer of death and suffering, Leo Naphta, and the heathen "priest" of life and Eros Mynheer Peeperkorn. The views espoused by Settembrini, Naphta and Peeperkorn reflect a preoccupation in Der Zauberberg with the themes of life, death, disease and Eros. Castorp's engagement with these themes positions the novel within the tradition of the Goethean Bildungsroman (novel of education), in which a fictional character is confronted with situations precipitous of intellectual and/or spiritual development. ${ }^{11}$

Der Zauberberg has given rise to an enormous quantity of scholarship beginning during Thomas Mann's lifetime and continuing until the present day. As renowned Thomas Mann scholar Helmut Koopmann noted in 1995: “[E]ine gewaltige Interpretationsindustrie hat sich seit 70 Jahren über den Zauberberg hergemacht". ${ }^{12}$ This wealth of scholarship is a solid base upon which to construct the present thesis. In particular, I was fortunate to be able to access the collection of secondary literature held at the Thomas Mann literary museum and research centre Buddenbrook House in Lübeck, Germany. Here, two dissertations by Sven Jordan and Karl Smikalla, available neither through general public libraries, university libraries, nor online, proved invaluable to my research, as did the register of Thomas Mann's complete letters edited by Hans Bürgin, Hans Otto Mayer and Yvonne Schmidlin ${ }^{13}$ (the original letters are situated in diverse archives in Germany and Switzerland).

Existing scholarship on Thomas Mann's work has primarily taken a source-critical approach. Source criticism focuses on the author's influence by other works, and the text

\footnotetext{
11 H. Koopmann. "Philosophischer Roman oder romanhafte Philosophie? Zu Thomas Manns lebensphilosophischer Orientierung in den zwanziger Jahren”, in R. Wolff (ed.). Aufsätze zum Zauberberg. Bonn: Bouvier Verlag, 1988, pp. 61-88, here, p. 66. Thomas Mann's cultural criticism also links him to novels of the Weimar Republic, for example Erich Kästner's Fabian and Alfred Döblin's Berlin Alexanderplatz (H. Lehnert. "Thomas Mann und die Literatur seiner Zeit", in H. Koopmann (ed.). Thomas Mann Handbuch, op. cit., pp. 137-163, here, p. 154).

${ }^{12}$ H. Koopmann. "Schlußwort”, in T. Sprecher (ed.). Das Zauberberg Symposium, op. cit., pp. 265-68, here p. 265.

${ }^{13}$ H. Bürgin, H. O. Mayer and Y. Schmidlin (eds.). Die Briefe Thomas Manns. Regesten und Register, vols. I-V. Frankfurt am Main: S. Fischer Verlag, 1977-1987. The Erika Mann edition of Thomas Mann's letters and the letters published in the Thomas Mann. Große Kommentierte Frankfurter Ausgabe are not complete.
} 
is analysed as a closed unit of finite meaning encoded by the author. In contrast, the newer field of intertextuality moves away from this traditional view of author and text by focusing on the relationships between texts and on the reader's role in their recognition. As the literary theorist Graham Allen states: "The act of reading [...] plunges us into a network of textual relations". ${ }^{14}$ Although simple textual relations are also the subject of source-critical study, they are viewed in the context of the author's assimilation and reproduction of ideas. Intertextual analysis, in contrast, acknowledges more complex dialogue between texts that can be independent of the author.

This intertextual dialogue is particularly apparent in the novel, which the Russian literary theorist Mikhail Bakhtin regards as fundamentally different from the other literary genres due to its nature as a "higher unity" of individual voices. ${ }^{15}$ The consequent polylogicality of the novel is further linked to an internal centrifugal force that dialogises discourses, ${ }^{16}$ as well as to the novel's nature as a dynamic, indeterminate form constantly adapting itself to reflect contemporary reality. ${ }^{17}$

Der Zauberberg is a superb example of the inherent intertextuality of such a novel. Although Thomas Mann's use of his material is unique, he borrowed many of the ideas on life, death, disease and Eros in Der Zauberberg from his extensive reading of philosophy, psychology and sociology. Mann wove these ideas into his own work using a compositional "Montage-Technique": 18 “[Ein] Aufmontieren von faktischen, historischen, persönlichen, ja literarischen Gegebenheiten". ${ }^{19}$ This technique was also used to compose Der

\footnotetext{
${ }^{14}$ G. Allen. Intertextuality: the New Critical Idiom. London: Routledge, 2000, p. 1.

${ }^{15}$ M. M. Bakhtin. "Discourse in the Novel", in M. Holquist (transl. and ed.). The Dialogic Imagination. Four Essays by M. M. Bakhtin. Austin: University of Texas Press, 1981, pp. 259-422, here, p. 263.

${ }^{16}$ Ibid., p. 273.

${ }^{17}$ M. M. Bakhtin. "Epic and Novel”, in M. Holquist (transl and ed.). The Dialogic Imagination. Four Essays by M. M. Bakhtin, op. cit., pp. 3-40, here, pp. 3-7.

${ }^{18}$ Letter to Theodor Adorno of 30 December 1945, quoted in E. Heftrich. "Vom höheren Abschreiben", in E. Heftrich and H. Koopmann (eds.). Thomas Mann und Seine Quellen. Festschrift für Hans Wysling. Frankfurt am Main: Vittorio Klostermann Verlag, 1991, pp. 1-20, here, pp. 18-19. Also quoted in H. Koopmann. "Doktor Faustus", in H. Koopmann (ed.). Thomas Mann Handbuch, op. cit., pp. 445-97, here, p. 481.

${ }^{19}$ P. Mendelssohn (ed.). Thomas Mann. Gesammelte Werke, vol. XI, p. 165; also quoted in H. Koopmann. "Doktor Faustus", op. cit., p. 480.
} 
Zauberberg, which Thomas Mann referred to in 1939 as a "Riesenteppich". ${ }^{20}$ The intentional inclusion of ideas from other works into Der Zauberberg is merely the tip of the iceberg. As Mann wrote in 1944: “[O]ne could be influenced in this [psychoanalytical] sphere without any direct contact with Freud's work because for a long time the air had been filled with the thoughts and results of the psychoanalytic school". ${ }^{21}$ This statement implies that Mann's work, including Der Zauberberg, may contain unintentional links to Freudian psychoanalysis. The plethora of textual relationships produced both intentionally and unintentionally promises to make Der Zauberberg a particularly rewarding subject of intertextual analysis. ${ }^{22}$

At the present time, only a handful of intertextual analyses of Der Zauberberg has been undertaken, notable examples being by Michael Maar (1997), Barbara Beßlich (2002), and Claudia Gremler (2003). ${ }^{23}$ Maar has researched the intertextual connections between Der Zauberberg and the work of Hans Christian Andersen, and links the characters of Der Zauberberg to those of Andersen's fairy tales. Beßlich examines the intertextual relations between Der Zauberberg and Oswald Spengler's Untergang des Abendlandes (1918), and investigates how the novel relates to Spengler's concept of Endzeit (final stage). Within her study of Thomas Mann's oeuvre in relation to the works of the Danish author Hermann Bang, Gremler's analysis of Der Zauberberg focuses on the theme of homosexuality and its links to the portrayal of women and the artist.

Beßlich's and Gremler's analyses reflect the prevalence of the themes of death, disease and Eros in Der Zauberberg. My thesis builds on the work of these two scholars by

\footnotetext{
${ }^{20}$ Here, Thomas Mann quotes Heine: "Seines Liedes Riesenteppich - zweimalhunderttausend Verse” (Mann. "Einführung in den Zauberberg", op. cit., p. 332).

${ }^{21}$ Mann. Letter (in English) to Frederick J. Hoffman of 27 January 1944, quoted in H. Wysling (ed.). Thomas Mann. Selbstkommentare: Der Zauberberg. Frankfurt am Main: S. Fischer Verlag, 1993, p. 142; also quoted in F. J. Beharriell. "Never without Freud: Freud's Influence on Mann", in K. Hughes (ed.). Thomas Mann in Context. Worchester, Mass.: Clark University Press, 1978, pp. 1-15, here, p. 5.

${ }^{22}$ Claudia Gremler argues that intertextual analysis differs from a source-critical approach following the interest of intertextual theorists in the intentional or unintentional nature of intertextual connections (G. Gremler. Fern im dänischen Norden ein Bruder: Thomas Mann und Hermann Bang, eine literarische Spurensuche. Göttingen: Vandenhoeck \& Ruprecht Verlag, 2003, p. 18).

${ }^{23}$ M. Maar. Geister und Kunst: Neuigkeiten aus dem Zauberberg. Frankfurt am Main: S. Fischer Verlag, 1997; B. Beßlich. Faszination des Verfalls: Thomas Mann und Oswald Spengler. Berlin: Akademie Verlag, 2002; C. Gremler, op. cit.
} 
similarly examining the portrayal of life, death, disease and Eros in the novel using intertextual theory. Yet my chosen intertexts are unique: the present study breaks new ground by investigating the themes of life, death, disease and Eros in relation to the works of the philosopher-poet Friedrich von Hardenberg (Novalis), of the philosophers Arthur Schopenhauer and Friedrich Nietzsche, and of the psychologist Sigmund Freud. The influence of these thinkers on Der Zauberberg has been documented by source-critical study, yet their combined significance has principally been ignored. In addition, the relation of these thinkers (individually or in combination) to Der Zauberberg has not yet been the subject of intertextual analysis. This lack is addressed by the present study, which is the first to investigate these four thinkers together in the context of Der Zauberberg, and the first to apply intertextual analysis to the task.

Of particular interest for my thesis is the heuristic use of intertextuality, i.e. the significance of textual relations for the meaning of a text. This heuristic function closely follows Thomas Mann's own understanding of meaning as the product of relationships. Reflecting on his novella Der Tod in Venedig (1912) in 1930, Mann concluded: "Ich liebe dies Wort: Beziehung. Mit seinem Begriff fällt mir der des Bedeutenden, so relativ er immer auch zu verstehen sei, durchaus zusammen. Das Bedeutende, das ist nichts weiter als das Beziehungsreiche". ${ }^{24}$ My analysis of Der Zauberberg pays homage to Mann's presumably both intratextual and intertextual idea by demonstrating that the intertextual dialogue within the novel contributes to the sum of its meaning. I aim to show that recognition of intertextual connections between Der Zauberberg and the work of Novalis, Schopenhauer, Nietzsche and Freud enrich the reader's understanding of life, death, disease and Eros as they are presented in the novel.

The analysis of life, death, disease and Eros in Der Zauberberg is a complex undertaking that invites initial division into smaller units. I therefore plan to first investigate the nature of death and its relation to life. I then compare the nature of life to that of disease, before investigating links between life, disease and death. I subsequently analyse the theme of Eros in the novel, and examine its relationship first to life, and then to death and disease.

\footnotetext{
${ }^{24}$ P. Mendelssohn (ed.). Thomas Mann. Gesammelte Werke, vol. XI, op. cit., pp. 123-24; also quoted in M. Dierks. "Traumzeit und Verdichtung. Der Einfluß der Psychoanalyse auf Thomas Manns Erzählweise", in E. Heftrich and H. Koopmann (eds.). Thomas Mann und Seine Quellen, op. cit., pp. 111-37, here, p. 118.
} 
I anticipate finding strong concordant and dialogic relations between these themes, following Thomas Mann's interest in the principles of antithesis and synthesis. ${ }^{25}$ Woven into the discussion of life, death, disease and Eros outlined above will be an investigation of their impact on the pre-World War I society presented in the novel.

I anticipate that the portrayal of life, death, disease and Eros in Der Zauberberg will reflect the philosophical, psychological and sociological angles of the intertexts. Although Novalis, Schopenhauer and Nietzsche are primarily regarded as philosophers, Thomas Mann recognised that their work is also highly psychological. In the Betrachtungen eines Unpolitischen, for example, Mann refers to Nietzsche as "der unvergleichlich größte und erfahrenste Psychologe der Dekadenz". ${ }^{26}$ In the essay "Schopenhauer" (1938), Mann draws a parallel between Schopenhauer's Wille (Will), Nietzsche's Dionysus (an artistic drive) and Freud's Es (id), ${ }^{27}$ and in the essay "Die Stellung Freuds in der modernen Geistesgeschichte" (1929), he discusses the work of Novalis, Schopenhauer and Nietzsche in the context of Freudian psychoanalysis. ${ }^{28}$ Conversely, Mann recognised Freud's additional interests in philosophy, sociology and anthropology, ${ }^{29}$ as well as Novalis's, Schopenhauer's and Nietzsche's preoccupation with culture. ${ }^{30}$

The work of Novalis, Schopenhauer, Nietzsche and Freud represents a progression of philosophical, psychological and sociological thought from the late $18^{\text {th }}$ to the early $20^{\text {th }}$ century. Thomas Mann himself links the two eras, believing to see Romantic roots in the

\footnotetext{
${ }^{25}$ See H. Kurzke, op. cit., p. 91.

${ }^{26}$ Mann 13.1, p. 87.

${ }^{27}$ P. Mendelssohn (ed.). Thomas Mann. Gesammelte Werke in Einzelbänden. Leiden und Größe der Meister. Frankfurt am Main: S. Fischer Verlag, p. 714. See also H. Wysling. "Schopenhauer-Leser Thomas Mann", in Schopenhauer Jahrbuch, vol. 64. Würzburg: Königshausen \& Neumann, 1983, pp. 61-79, here, p. 62.

${ }^{28}$ P. Mendelssohn (ed.). Thomas Mann. Gesammelte Werke in Einzelbänden. Leiden und Größe der Meister, op. cit., pp. 879-904.

${ }^{29}$ This is apparent in Mann’s essay “Die Stellung Freuds in der modernen Geistesgeschichte":

[Die Aufsätze von Totem und Tabu überschreiten] die medizinische Sphäre weit ins allgemein Geisteswissenschaftliche hinaus [...] und [reißen] vor dem der Frage des Menschen nachhängenden Leser ungeheure Perspektiven seelischer Vergangenheit, Urwelttiefen moralischer, gesellschaftlicher, mythisch-religiöser Früh- und Vorgeschichte der Menschheit erhellend auf[]. (Mann. "Die Stellung Freuds in der modernen Geistesgeschichte", in Die psychoanalytische Bewegung, vol. 1. Wien: Internationaler Psychoanalytischer Verlag, 1929, pp. 3-32, here, p. 3).
}

${ }^{30}$ Mann 15.1, pp. 514-59; Mann 19.1, p. 358. 
$20^{\text {th }}$ century. Not only does he regard Novalis as representative of German Romanticism, ${ }^{31}$ and Schopenhauer's pessimistic metaphysics as conforming with the Romantic affirmation of death, but Mann also regards Nietzsche as "ein[en] späte[n] Sohn der Romantik" following the latter's conception of disease. ${ }^{32}$ It is also interesting to note that Mann traces Freud's $20^{\text {th }}$-century psychology to a Romantic interest in the unconscious. ${ }^{33}$ This view of Freud as a $20^{\text {th }}$-century reflection of $19^{\text {th }}$-century thought mirrors Thomas Mann's own position as a $20^{\text {th }}$-century writer primarily influenced by works of Romanticism. ${ }^{34}$ Yet Mann also finds inspiration for the $20^{\text {th }}$ century in the late $18^{\text {th }}$ and middle $19^{\text {th }}$ century, arguing in the speech "Von deutscher Republik" for the creation of a Third Reich of religious humanism using the example of, among others, Novalis and Nietzsche. ${ }^{35}$ Inspired by this "in Beziehung setzen" 36 of past and present, my thesis investigates the concordant and/or conflicting intersection of these thinkers' ideas, and to what extent these impact on the portrayal of life, death, disease and Eros in Der Zauberberg. I expect to find a certain tension between ideas from the late $18^{\text {th }}$ century, the $19^{\text {th }}$ century and the early $20^{\text {th }}$ century, and am interested in how Thomas Mann combines these within the pre-World War I context of the novel.

Another topic of investigation in my thesis is the variety of belief systems represented within the novel. Thomas Mann's mother was a Roman Catholic, and Mann himself was raised as a Lutheran according to the tradition of his father's family. However, Mann later states in the section "Vom Glauben" from Betrachtungen eines Unpolitischen: "Nein, ich besitze keine [Religion]." 37 The relation of this atheism to Mann's religious upbringing is a fascinating subject of investigation for the present study, and I anticipate

\footnotetext{
${ }^{31}$ Mann 15.1, pp. 514-59.

32 Ibid., p. 790; see also ibid., pp. 788-93.

${ }^{33}$ P. Mendelssohn (ed.). Thomas Mann. Gesammelte Werke in Einzelbänden. Leiden und Größe der Meister, op. cit., p. 884.

${ }^{34}$ In the Betrachtungen eines Unpolitischen, Mann claims: "Ich bin, im geistig Wesentlichen, ein rechtes Kind des Jahrhunderts, in das die ersten 25 Jahre meines Lebens fallen: des neunzehnten.” (Mann 13.1, p. 24)

35 Mann 15.1, p. 549; see also H. Wysling. "Der Zauberberg”, op. cit., p. 399.

${ }^{36}$ Mann 15.1, p. 537.

${ }^{37}$ Mann 13.1, p. 583.
} 
that these differing beliefs will be significant to the portrayal of life, death, disease and Eros in Der Zauberberg.

In chapter one, I justify my choice of thinkers, establishing which of their works Thomas Mann read before or during the inception of Der Zauberberg, as well as which works are pertinent to the present focus on life, death, disease and Eros. I then position my thesis within the context of existing source-critical scholarship. I also define my use of intertextual theory, looking at models of intertextuality and at existing intertextual criticism of Thomas Mann's work in order to design a methodology specific to this study. Chapter one concludes with an outline of this methodology, which combines specific elements of the typologies of Manfred Pfister and Peter Stocker in an intertextual model that acknowledges the importance of both author/text and reader for the creation of meaning.

The body of the thesis is structured according to an initial interest in the themes of life, death, and disease (chapters 2 and 3) and their subsequent relation to culture (chapter 4). This is followed by an examination of Eros, life, death and disease (chapter 5) which leads to a concluding investigation of these themes in the context of the culture portrayed in the novel (chapter 6). Thus, in chapter two, I apply the intertextual methodology designed in chapter one to an investigation of death and its relation to life. I then examine the role of culture and religion in early $20^{\text {th }}$-century attitudes towards death. In addition, this chapter includes an analysis of Hans Castorp's visionary balance between life and death in the chapter section "Schnee", and places this in the context of the Last Judgement.

Chapter three begins by focusing on the nature of life, before examining the relation of life to disease and to death. The portrayal of life's inception in the chapter section "Forschungen" is then explored, along with related links between the concepts of Mind, God and disease and their impact on human nature.

Chapter four analyses the portrayal of disease and culture in the novel, specifically with regard to the symptoms of lethargy and tension prevalent in the chapter sections "Der große Stumpfsinn" and "Die große Gereiztheit". These symptoms and their chronology are then examined in the context of the pre-World War I society of sanatorium Berghof.

Chapter five expands on the findings of chapter three by exploring the interrelation of life, disease, Eros and death. These themes are also examined in relation to concepts of 
femininity, masculinity and the homosexual aesthetic, and the discussion of the nature of God from chapter three is continued in the context of both Eros and disease.

Chapter six examines the implications of death, disease and Eros for culture, beginning with an exploration of Eros and morality. This is expanded in a discussion of language and vision and their relation to culture and barbarity, and is followed by an investigation of lasciviousness and decadence. Finally, the role of disease and Eros in the decadent dissolution of morality is explored together with the nature of humanity as it is portrayed in the novel. 


\section{Chapter 1 Design and intention}

\subsection{The choice of intertexts}

The range of intertexts investigated in this study is partly justified by Thomas Mann's correspondence from 1937 with the American literary critic Joseph Angell. Thomas Mann was notoriously reluctant to divulge his literary influences, ${ }^{38}$ and when Angell wrote to enquire which authors had influenced Mann while working on Der Zauberberg, Mann claimed to have forgotten not only what he had read but even the ideas he had adopted:

Nachdem sie ihren Dienst erfüllt haben, in eine Arbeit eingegangen und darin aufgegangen und verarbeitet sind, kommen sie mir bald aus dem Sinn, ja auch aus den Augen und es ist fast, als ob ich von ihnen nicht mehr wissen wollte und das Gedächtnis daran verdrängte. ${ }^{39}$

Nevertheless, Mann admits in the same letter that he was influenced in general by the work of Novalis, Schopenhauer and Nietzsche. The significance of these three thinkers is confirmed by further letters and early notebooks that document Mann's exposure to their work as a young man, ${ }^{40}$ and Thomas Mann scholars have demonstrated that ideas from the

\footnotetext{
${ }^{38}$ See Mann. "Zur Physiologie des dichterischen Schaffens" (1928), in P. Mendelssohn (ed.). Thomas Mann. Gesammelte Werke, vol. XI, op. cit., pp. 777-80; see also S. Cerf. "Georg Brandes' View of Novalis: A Current within Thomas Mann's Der Zauberberg”, in Colloquia Germanica, vol. 14. Tübingen: A. Francke Verlag, 1981, pp. 114-29, here, p. 127. The researcher's task is also hampered by a lack of relevant material: Mann's Zauberberg notes were destroyed in World War II (S. Cerf, op. cit., p. 116; see also Mann. Letter to Monika Mann of 21 December 1950, quoted in H. Wysling (ed.). Thomas Mann. Selbstkommentare: Der Zauberberg, op. cit., p. 163). Mann also burnt his diaries in 1896, 1944 and 1945, with the result that, although diaries from 1933 on survive, there are none before 1918 and only a few from the period September 1918 to December 1921 (I. and W. Jens. "Die Tagebücher", in H. Koopmann (ed.). Thomas Mann Handbuch, op. cit., pp. 721-41, here, p. 721).
}

${ }^{39}$ Mann. Letter of 11 May 1937, in E. Mann (ed.). Thomas Mann Briefe 1937-1947, vol. II. Frankfurt am Main: S. Fischer Verlag, 1978, pp. 22-25, here, pp. 23-24.

${ }^{40}$ The young Thomas Mann mentions Georg Brandes' Die romantische Schule in Deutschland in a notebook from 1894/5 (H. Wysling and Y. Schmidlin (eds.). Thomas Mann. Notizbücher 1-6, vol. 1. Frankfurt am Main: S. Fischer Verlag, 1991, p. 39). However, this reference is to Brandes' chapter on Romantic politicians, and it is uncertain whether Mann also read the chapters on Novalis at this time. Thomas Mann's first epistolary reference to Novalis is a letter to Philipp Witkop of 10 October 1903 (H. Bürgin, H. O. Mayer and Y. Schmidlin (eds.). Die Briefe Thomas Manns. Regesten und Register, vol. I 1889-1933, op. cit., pp. 53-54), and subsequent letters to Witkop of 14 August 1907 (ibid., p. 88) and to Paul Steegemann of 18 August 1920 (E. Mann (ed.). Thomas Mann Briefe 1889-1936, vol. I, op. cit., pp. 181-82). Thomas Mann first refers to Schopenhauer in a notebook of 1894/5 (H. Wysling and Y. Schmidlin (eds.). Thomas Mann. Notizbücher 16, vol. 1, op. cit., p. 28). Herbert Lehnert believes that Mann was probably introduced to Nietzsche in 1894 
work of Novalis, Schopenhauer and Nietzsche permeate much of Mann's oeuvre. ${ }^{41}$ My inclusion of Freud in this study is justified by Thomas Mann's discussion of Schopenhauer, Nietzsche and Freud in the essay "Schopenhauer", and by his study of Novalis, Schopenhauer and Nietzsche and Freud in the essay "Die Stellung Freuds in der modernen Geistesgeschichte".

Determining which texts from the oeuvre of Novalis, Schopenhauer, Nietzsche and Freud to analyse within the thesis was dependent on two factors: which texts included a discussion of the themes of life, death, disease and Eros, and which texts Thomas Mann actually read. In a letter to Paul Steegemann of 18 August 1920, for example, Mann discusses Novalis's "Hymnen an die Nacht" (1797), ${ }^{42}$ the primary subject of which is the erotic union between the individual and God. These are also the themes of Novalis's “Geistliche Lieder" (1802). In addition, Mann used underlining to highlight a connection between death, disease and Eros in his copy of Novalis's "Fragmente" (1798-1800). ${ }^{43}$ This underlining is concordant with Mann's reading of secondary literature, notably Georg Brandes' chapters on Novalis from Die romantische Schule in Deutschland (1900). ${ }^{44}$ Mann's note "Zbg" in several places among the exclamation marks and underlined passages in his copy of Die romantische Schule establishes the direct influence of Brandes'

by his brother, Heinrich (H. Lehnert, op. cit., p. 143). Thomas Mann first mentions Nietzsche in a notebook of 1894/95 (H. Wysling and Y. Schmidlin (eds.). Thomas Mann. Notizbücher 1-6, vol. 1, op. cit., p. 33), and in a letter to Otto Grautoff of 13 November 1894 (Mann 21, p. 35). Another early letter of May 1895 also refers to Nietzsche (H. Bürgin, H. O. Mayer and Y. Schmidlin (eds.). Die Briefe Thomas Manns. Regesten und Register, vol. I 1889-1933, op. cit., p. 524).

${ }^{41}$ Novalis takes a central role in Mann's speech "Von deutscher Republik" (Mann 15.1, pp. 514-59). Nietzsche's importance is confirmed in Betrachtungen eines Unpolitischen (Mann 13.1, pp. 81-82, 87), as well as in Mann's essay on Nietzsche, "Nietzsches Philosophie im Lichte unserer Erfahrung" (Mann 19.1, pp. 185-226). Mann's interest in Schopenhauer is clear from the essay "Schopenhauer" (P. Mendelssohn (ed.). Thomas Mann. Gesammelte Werke in Einzelbänden. Leiden und Größe der Meister, op. cit., pp. 664716). See also P. Pütz. "Thomas Mann und Nietzsche”, in Peter Pütz (ed.). Thomas Mann und die Tradition. Frankfurt am Main: Athenäum Verlag, 1971, pp. 226-249, here, p. 225; T. J. Reed. "Thomas Mann und die literarische Tradition”, in Helmut Koopmann (ed.). Thomas Mann Handbuch, op. cit., pp. 95-136, here, p. 99.

${ }^{42}$ E. Mann (ed.). Thomas Mann Briefe 1889-1936, vol. I, op. cit., pp. 181-82.

${ }^{43}$ S. Cerf, op. cit., p. 117.

${ }^{44}$ G. Brandes. Hauptströmungen der Literatur des neunzehnten Jahrhunderts: Die romantische Schule, vol. 2: Die romantische Schule in Deutschland. Berlin: Reiss Verlag, 1924, pp. 229-303. 
conception of Novalis on the composition of Der Zauberberg, ${ }^{45}$ and Thomas Mann's view of Novalis as the German Romantic per se witnessed in the speech "Von deutscher Republik" also appears to have been influenced by Brandes, who presents Novalis as a key figure in the Romantic break away from Enlightenment thought. ${ }^{46}$ Another text worthy of consideration is Novalis's incomplete novel, Heinrich von Ofterdingen, which Brandes analyses in Die romantische Schule, and which similarly contains the themes of death and love.

Reminiscing in 1952, Thomas Mann described his initial contact with Schopenhauer (Die Welt als Wille und Vorstellung [1819]) as “das stärkste Lese-Erlebnis meiner Jugend". ${ }^{47}$ The potential significance of Schopenhauer's philosophy for the portrayal of life, death, disease and Eros in Der Zauberberg is clear from Schopenhauer's separation of existence into Wille (Will) and Welt als Vorstellung (world as representation), and his parallel devaluation of life as a state of infinite suffering perpetuated by procreation. ${ }^{48}$

Thomas Mann's early study of Nietzsche's work began in 1894, and by 1917 he had read most of Nietzsche's published work. ${ }^{49}$ The themes of life, death, disease and Eros are present in Nietzsche's critique of decadence (Jenseits von Gut und Böse [1886], Zur

\footnotetext{
45 B. Schader. Schwindsucht - Zur Darstellung einer tödlichen Krankheit in der deutschen Literatur vom poetischen Realismus bis zur Moderne. Frankfurt am Main: Peter Lang Verlag, 1987, p. 143; H. Eichner. "Thomas Mann und die deutsche Romantik", in W. Paulsen (ed.). Das Nachleben der Romantik in der modernen deutschen Literatur. Heidelberg: 1969, pp. 152-73, here, p. 153.

${ }^{46}$ G. Brandes, op. cit., pp. 244-25; see also S. Cerf, op. cit., p. 119.

${ }^{47}$ Mann. Letter to Ferdinand Lion of 13 March 1952, in E. Mann (ed.). Thomas Mann Briefe 1948-1955 u. Nachlese, vol. III, op. cit., p. 248. See also H. Koopmann. "Thomas Mann und Schopenhauer", in P. Pütz (ed.). Thomas Mann und die Tradition, op. cit., pp. 180-200, here, p. 184.

48 This fundamentally negative view of life allegedly contributed to Thomas Mann's own pessimistic "seelische[r] Grundstimmung" (Mann 13.1, p. 87).

49 Thomas Mann's first notebook from 1894/95 documents an intense interest in Nietzsche's work. The last third of this notebook contains the Russian literary theorist numerous Nietzsche aphorisms, mostly from Jenseits von Gut und Böse, with one from Der Fall Wagner. On page 68 of this notebook is a list of Nietzsche's work that Thomas Mann planned to buy. However, the books in his library (in which the date of purchase is noted) indicate that he did not acquire all of them at once: Der Fall Wagner was acquired in 1895, Morgenröte and Die fröhliche Wissenschaft in 1896, Die Geburt der Tragödie aus dem Geiste der Musik and the Unzeitgemäße Betrachtungen in 1899, the first volume of Menschliches, Allzumenschliches in 1900 and the second volume in 1906 (editor's note in H. Wysling and Y. Schmidlin (eds.). Thomas Mann. Notizbücher 1-6, vol. 1, op. cit., p. 50). A letter of 18 August 1920 also indicates that Mann read Ecce Homo (E. Mann (ed.). Thomas Mann Briefe 1889-1936, vol. I, op. cit., pp. 181-82).
} 
Genealogie der Moral [1887], Der Fall Wagner [1888], Nietzsche contra Wagner [1889], Ecce Homo [1889]), ${ }^{50}$ in his psychological theory of inner drives (Morgenröte [1881], Die Geburt der Tragödie aus dem Geiste der Musik [1872]); in his antithesis of life and morality (Die Geburt der Tragödie aus dem Geiste der Musik, Menschliches, Allzumenschliches [1878], Ecce Homo), as well as in his views on nature and art (Die fröhliche Wissenschaft [1882]), and on women (Menschliches, Allzumenschliches, Die fröhliche Wissenschaft; Jenseits von Gut und Böse, Also sprach Zarathustra [1886]). Mann was also influenced by Ernst Bertram's discussion of Nietzsche's affirmation of life in its totality (including disease) in Nietzsche. Versuch einer Mythologie (1918); ${ }^{51}$ Mann's letter to Bertram of 21 September 1918 indicates that Bertram's book contributed to a shift in Mann's philosophy away from Schopenhauerian pessimism, a shift that was also influenced by the experience of World War I. ${ }^{52}$

Thomas Mann's knowledge of the views of life, death, disease and Eros in the work of Novalis, Schopenhauer and Nietzsche is clear; the significance of Freud's theories for Mann's writing, on the other hand, has been the subject of scholarly debate. This is due to the similarities between Freud's theories and those of Schopenhauer and Nietzsche, ${ }^{53}$ as well as to the scarcity of written evidence: Thomas Mann mentions Freud a mere three times in his notes and diaries, discussing “Zeitgemäßes über Krieg und Tod” (1915) in 1916; "J4 "Jenseits des Lustprinzips" (1920) in 1921, ${ }^{55}$ and Freud's Gesammelte Schriften in 1925 (Mann studied Freud intensively at this time for use in his tetralogy Joseph und seine

\footnotetext{
${ }^{50}$ Mann 13.1, pp. 81-82, 87.

${ }^{51}$ H. Wysling. “Der Zauberberg”, op. cit., p. 399. Mann read Bertram’s work in 1918 shortly before resuming work on Der Zauberberg (Mann 22, pp. 249-53).

52 Mann 22, pp. 249-53; see also Mann 13.1, p. 93.

${ }^{53}$ One example of these similarities is the concept of unconscious motivation present in the work of all three thinkers (F. J. Beharriell, op. cit., p. 8; see also Nietzsche KSA 3, p. 113). References in this thesis to Nietzsche KSA 1-15 concern the following edition: G. Colli and M. Montinari (eds.). Friedrich Nietzsche. Kritische Studienausgabe. München: Deutscher Taschenbuch Verlag, 1999.

${ }^{54}$ H. Wysling and Y. Schmidlin (eds.). Thomas Mann. Notizbücher 7-14, vol. 2. Frankfurt am Main: S. Fischer Verlag, 1991, pp. 46-47. Also referred to in H. Wysling. "Thomas Manns Rezeption der Psychoanalyse", in B. Bennett (ed.). Probleme der Moderne. Studien zur deutschen Literatur von Nietzsche bis Brecht. Festschrift für Walter Sokel. Tübingen: Max Niemeyer Verlag, 1983, pp. 201-22, here, p. 201.

${ }^{55}$ Mann. Diary entry of 24 May 1921 quoted in M. Dierks. "Thomas Mann und die Tiefenpsychologie", in H. Koopmann (ed.). Thomas Mann Handbuch, op. cit., pp. 284-300, here, pp. 292-93; see also H. Wysling. "Thomas Manns Rezeption der Psychoanalyse", op. cit., p. 207.
} 
Brüder) ${ }^{56}$ Academic disagreement has also been fuelled by Thomas Mann's contradictory statements. In 1925, for example, Mann claimed that Freud's theories had influenced his novella Der Tod in Venedig (1912), ${ }^{57}$ yet in 1950, Mann denied having read any Freud before 1925. ${ }^{58}$ Early scholarship (with the exception of F. J. Beharriell [1978]) followed Mann's later statement; ${ }^{59}$ however, Manfred Dierks (1991) has validated Mann's claim from 1925 by establishing the influence of Freud's depth-psychology on Der Tod in Venedig: this dates Mann's first reading of Freud at $1911 .{ }^{60}$ The presence of Freud's concept of the Wiederkehr des Verdrängten (the return of the repressed) in Der Tod in Venedig suggests that Mann's first contact with Freud may have been Der Wahn und die Träume in W. Jensens 'Gradiva' (1907). ${ }^{61}$ This essay is particularly interesting for the present study because it contains many key psychoanalytical ideas that potentially informed Mann's conception of life, death, disease and Eros. These include the Wiederkehr des Verdrängten and the symbolic use of ancient civilisation, ${ }^{62}$ the concept of unconscious motivation, the psychoanalytical-cathartic method, the connection between the artist and

\footnotetext{
${ }^{56}$ M. Dierks. "Thomas Mann und die Tiefenpsychologie", op. cit., p. 286; B. Urban. "Einleitung", in Sigmund Freud. Der Wahn und die Träume in W. Jensens 'Gradiva'. Frankfurt am Main: S. Fischer Verlag, 2003, pp. 7-44, here, p. 43; F. J. Beharriell, op. cit., p. 3.

${ }^{57}$ Mann. Interview with the Italian newspaper Turin Stampa, quoted in H. Sauereßig. "Die Tuberkulose als Paradigma des Lebensgefühls", in Med Welt, vol. 33, no. 12. Stuttgart: F. K. Schattauer Verlag, 1982, pp. 428-34, here, p. 431. Also quoted in M. Dierks. "Thomas Mann und die Tiefenpsychologie", op. cit., p. 284, and in F. J. Beharriell, op. cit., p. 2.

${ }^{58}$ See Mann's letter to Donald Hirschbach of 16 December 1950, in H. Bürgin, H. O. Mayer and Y. Schmidlin (eds.). Die Briefe Thomas Manns. Regesten und Register 1944-1950, vol. III, op. cit., p. 792.

${ }^{59}$ See Hans Mayer, Herbert Lehnert and Manfred Dierks, referred to in M. Dierks. Studien zu Mythos und Psychologie bei Thomas Mann: an seinem Nachlass orientierte Untersuchungen zum 'Tod in Venedig', zum 'Zauberberg' und zur 'Joseph'-Tetralogie. Bern: A. Francke Verlag, 1972, pp. 127-29. Dierks (1972), for example, at first ascribed the psychological insights in Thomas Mann's early work exclusively to the work of Schopenhauer and Nietzsche (ibid., pp. 127-35).

${ }^{60}$ M. Dierks. "Traumzeit und Verdichtung. Der Einfluß der Psychoanalyse auf Thomas Manns Erzählweise”, op. cit., p. 111; M. Dierks. "Doktor Krokowski und die Seinen. Psychoanalyse und Parapsychologie in Thomas Manns Zauberberg", in T. Sprecher (ed.). Das Zauberberg Symposium, op. cit., pp. 173-96, here, p. 189; M. Dierks. "Thomas Mann und die Tiefenpsychologie", op. cit., p. 284. Also compare M. Dierks. "Thomas Mann und die Tiefenpsychologie", op. cit., p. 292 with M. Dierks. Studien zu Mythos und Psychologie bei Thomas Mann, op. cit., pp. 127, 129.

${ }^{61}$ B. Urban, op. cit., p. 43; M. Dierks. “Thomas Mann und die Tiefenpsychologie”, op. cit., p. 285.

${ }^{62}$ B. Urban, op. cit., pp. 16, 31-35; M. Dierks. "Thomas Mann und die Tiefenpsychologie”, op. cit., p. 285.
} 
neurosis, the interpretation of dreams, and the sexual theory. ${ }^{63}$ In addition, critics agree that Mann must have read Freud's Drei Abhandlungen zur Sexualtheorie (1905) before or during work on Der Zauberberg, ${ }^{64}$ and it seems likely that Mann was also familiar with Freud's essay “Die 'kulturelle' Sexualmoral und die moderne Nervosität” (1908). These essays on sexuality are particularly pertinent to the present study, as are Freud's essays on the meaning of life and death, "Zeitgemäßes über Krieg und Tod" and "Jenseits des Lustprinzips" (see above).

\subsection{Der Zauberberg and the work of Novalis, Schopenhauer, Nietzsche and Freud: the position of this study in relation to existing source-critical scholarship}

Der Zauberberg has attracted an enormous quantity of source-critical scholarship beginning during Thomas Mann's lifetime and continuing until the present day. ${ }^{65}$ Several monographs have been dedicated to the influence of Schopenhauer's philosophy on Thomas Mann's work, for example Werner Frizen's Zaubertrank der Metaphysik. Quellenkritische Überlegungen im Umkreis der Schopenhauer-Rezeption Thomas Manns (1980), ${ }^{66}$ Børge Kristiansen's Thomas Manns Zauberberg und Schopenhauers Metaphysik (1986), ${ }^{67}$ and Edo Reents' Zu Thomas Manns Schopenhauer-Rezeption (1998). ${ }^{68}$ Erkme

\footnotetext{
${ }^{63}$ In Der Wahn und die Träume in W. Jensens 'Gradiva', Freud notes that the hero Norbert acts "ohne selbst von dem Antrieb in seinem Innern zu wissen" (Freud VII, p. 41). References to Freud I-XVI in this thesis concern the following edition: A. Freud, E. Bibring, W. Hoffer, E. Kris and O. Isakower (eds.). Sigmund Freud. Gesammelte Werke, vols. I-XVIII. Frankfurt am Main: S. Fischer Verlag, 2008.

${ }^{64}$ H. Wysling. "Thomas Manns Rezeption der Psychoanalyse”, op. cit., p. 203; M. Dierks. "Thomas Mann und die Tiefenpsychologie”, op. cit., p. 292; F. J. Beharriell, op. cit., p. 3; B. Schader, op. cit., p. 188 ; B. Urban, op. cit., p. 43. With the exception of Bernd Urban, these scholars all follow Jean Finck's analysis of the Zauberberg chapter section "Analyse" and Freud's Drei Abhandlungen zur Sexualtheorie (J. Finck. Thomas Mann und die Psychoanalyse. Paris: Société d'Edition 'Les Belles Lettres', 1973).

${ }^{65}$ H. Koopmann. "Schlußwort”, in T. Sprecher (ed.). Das Zauberberg Symposium, op. cit., pp. 265-68, here, p. 265.

${ }^{66}$ W. Frizen. Zaubertrank der Metaphysik. Quellenkritische Überlegungen im Umkreis der SchopenhauerRezeption Thomas Manns. Frankfurt am Main: Peter Lang Verlag, 1980.
}

67 B. Kristiansen. Thomas Manns Zauberberg und Schopenhauers Metaphysik. Bonn: Bouvier, 1986. Kristiansen's original work appeared in 1978 under the title Unform - Form - Überform. Thomas Manns Zauberberg und Schopenhauers Metaphysik. Eine Studie zu den Beziehungen zwischen Thomas Manns Roman Der Zauberberg und Schopenhauers Metaphysik. (Kopenhagen: Akademisk Forlag, 1978).

68 E. Reents. Zu Thomas Manns Schopenhauer-Rezeption. E. Heftrich and H. Kurzke (eds.). Studien zur Literatur- und Kulturgeschichte, vol. 12. Würzburg: Königshausen und Neumann, 1998. 
Joseph's monograph Nietzsche im 'Zauberberg' $(1996)^{69}$ is joined by smaller essays and book chapters on the influence of Nietzsche's work on Der Zauberberg, including Peter Pütz's two essays "Thomas Mann und Nietzsche" $(1971)^{70}$ and "Krankheit als Stimulans des Lebens. Nietzsche auf dem Zauberberg” (1995); ${ }^{71}$ Jill A. Kowalik's “"Sympathy with Death': Hans Castorp's Nietzschean Resentment" (1985), ${ }^{72}$ and Michael Hinz's Verfallsanalyse und Utopie. Nietzsche-Rezeption in Thomas Manns 'Zauberberg' und in Robert Musils 'Der Mann ohne Eigenschaften' (2000). ${ }^{73}$ Studies of Freud's influence on Der Zauberberg are included in Cecil A. Noble's Krankheit, Verbrechen und künstlerisches Schaffen bei Thomas Mann (1970), ${ }^{74}$ in Jean Finck's Thomas Mann und die Psychoanalyse (1973), ${ }^{75}$ and in Manfred Dierks' two essays “Traumzeit und Verdichtung. Der Einfluß der Psychoanalyse auf Thomas Manns Erzählweise" $(1991)^{76}$ and "Doktor Krokowski und die Seinen. Psychoanalyse und Parapsychologie in Thomas Manns Zauberberg" (1995). ${ }^{77}$ A source-critical investigation of Novalis's work in the context of Der Zauberberg has been undertaken by Käte Hamburger in Thomas Mann und die Romantik. Eine problemgeschichtliche Studie (1932), ${ }^{78}$ and by Steven Cerf in "Georg Brandes' View of

69 E. Joseph. Nietzsche im 'Zauberberg'. Thomas-Mann-Studien, vol. 14. Frankfurt am Main: Vittorio Klostermann Verlag, 1996.

${ }^{70}$ P. Pütz. "Thomas Mann und Nietzsche”, op. cit.

${ }^{71}$ P. Pütz. "Krankheit als Stimulans des Lebens. Nietzsche auf dem Zauberberg”, op. cit.

72 J. A. Kowalik. "'Sympathy with Death': Hans Castorp's Nietzschean Resentment", in The German Quarterly. Hoboken, New Jersey: Wiley-Blackwell, 1985, pp. 27-48.

${ }^{73}$ M. Hinz. Verfallsanalyse und Utopie. Nietzsche-Rezeption in Thomas Manns 'Zauberberg' und in Robert Musils 'Der Mann ohne Eigenschaften'. Beiträge zur Robert-Musil-Forschung und zur neueren österreichischen Literatur, vol. 13. St. Ingbert: Röhrig Universitätsverlag, 2000. Franziska Schößler's intertextual study of Nietzsche's work and Thomas Mann's “Königliche Hoheit" will be discussed in the following subchapter.

74 C. A. Noble. Krankheit, Verbrechen und künstlerisches Schaffen bei Thomas Mann. Europäische Hochschulschriften. Bern: Verlag Herbert Lang \& Cie AG, 1970.

75 J. Finck, op. cit.

${ }^{76}$ M. Dierks. "Traumzeit und Verdichtung. Der Einfluß der Psychoanalyse auf Thomas Manns Erzählweise”, op. cit.

77 M. Dierks. "Doktor Krokowski und die Seinen. Psychoanalyse und Parapsychologie in Thomas Manns Zauberberg", op. cit.

${ }^{78}$ K. Hamburger. Thomas Mann und die Romantik. Eine problemgeschichtliche Studie. H. Hecht (ed.). Neue Forschung. Arbeiten zur Geistesgeschichte der Germanischen und Romanischen Völker, vol. 15. Berlin: Junker \& Dünnhaupt Verlag, 1932. 
Novalis: A Current within Thomas Mann's 'Der Zauberberg'” (1981). ${ }^{79}$ Mention of the influence of Novalis's work on Der Zauberberg can also be found in Hermann Weigand's book The Magic Mountain. A Study of Thomas Mann's Novel Der Zauberberg (1965), ${ }^{80}$ and in Hans Eichner's essay “Thomas Mann und die deutsche Romantik” (1969). ${ }^{81}$

The focus on a single influence outlined above is paradoxically justified by the sheer quantity of textual relationships in Thomas Mann's work: if the discussion of one author's influence provides enough material for an entire book, why investigate more? However, there are good reasons to undertake a broader study. Scholars can be limited by the narrowness of their focus and end up arguing for the primacy of their chosen influence, for example in the disagreement between Børge Kristiansen and Terence J. Reed over the relative importance of Schopenhauer and Nietzsche for Thomas Mann's work. ${ }^{82}$ Furthermore, as Erkme Joseph has noted, a single-influence approach excludes the possibility of an overarching perspective. ${ }^{83}$ The broader scope of the present study, while excluding a single argumentative position, will enable a more complex interpretation of Der Zauberberg.

Of particular interest for this thesis are therefore source-critical essays that address more than one influence on Thomas Mann's work, for example Manfred Dierks' Studien zu Mythos und Psychologie bei Thomas Mann: an seinem Nachlass orientierte Untersuchungen zum 'Tod in Venedig', zum 'Zauberberg' und zur 'Joseph'-Tetralogie (1972) ${ }^{84}$ Helmut Koopmann's “Philosophischer Roman oder romanhafte Philosophie? Zu Thomas Manns lebensphilosophischer Orientierung in den zwanziger Jahren" (1988), ${ }^{85}$

\footnotetext{
${ }^{79}$ S. Cerf, op. cit.

${ }^{80}$ H. Weigand. The Magic Mountain. A Study of Thomas Mann's Novel Der Zauberberg. Chapel Hill, North Carolina: The University of North Carolina Press, 1965.

${ }^{81}$ H. Eichner, op. cit.

${ }^{82}$ B. Kristiansen. "Thomas Mann und die Philosophie", op. cit., p. 276; T. J. Reed, op. cit., p. 101. Thomas Mann himself found it "schwer [...] auseinanderzuhalten, was er dem einzelnen [Schopenhauer und Nietzsche] verdankt” (Mann 13.1, p. 87).

${ }^{83}$ E. Joseph, op. cit., p. 3.

84 M. Dierks. Studien zu Mythos und Psychologie bei Thomas Mann: an seinem Nachlass orientierte Untersuchungen zum 'Tod in Venedig', zum 'Zauberberg' und zur 'Joseph'-Tetralogie, op. cit.

85 H. Koopmann. "Philosophischer Roman oder romanhafte Philosophie? $\mathrm{Zu}$ Thomas Manns lebensphilosophischer Orientierung in den zwanziger Jahren”, op. cit.
} 
Hans Wysling's “Der Zauberberg - als Zauberberg” (1995), ${ }^{86}$ and T.J. Reed's “Thomas Mann und die literarische Tradition" (2001). ${ }^{87}$ These works investigate how Thomas Mann blends and reinterprets the ideas of Schopenhauer and Nietzsche within Der Zauberberg. Dierks, for example, interprets Castorp's snow vision in Der Zauberberg as "Schopenhauers Doppelperspektiv" translated into Nietzsche's polarity of Apollo and Dionysus, i.e. as the realisation of Schopenhauer's philosophy as myth via Nietzsche. ${ }^{88}$ Helmut Koopmann observes the affirmation of Schopenhauer's Romantic concept of death and the confrontation of Novalis's and Nietzsche's Romantic ideas on disease. ${ }^{89}$ Wysling believes that Der Zauberberg combines the ideas of Schopenhauer and Nietzsche in a mix of "Pessimismus und Zukunftsglaube", 90 and Reed suggests that the compromise between political opposites (Nationalism and Republicanism) within Der Zauberberg represents the amalgamation of Schopenhauer's affirmation of death and Nietzsche's affirmation of life. ${ }^{91}$

Source-critical studies of three of the thinkers examined in this thesis in connection with Der Zauberberg include Karl Smikalla's Die Stellung Thomas Manns zur Romantik (1953). ${ }^{92}$ Smikalla discusses the work of Novalis, Schopenhauer and Nietzsche in relation to Thomas Mann's oeuvre. Examining the Romantic concept of Sympathie mit dem Tode (sympathy with death), he concludes that Der Zauberberg marks a break from this Romantic tradition with the help of Nietzsche's philosophy. Sven Jordan similarly includes Novalis and Nietzsche in a discussion of Schopenhauer and Der Zauberberg. In Das Organische zwischen Naturwissenschaft und Mystizismus. Thomas Manns 'Zauberberg' aus der Perspektive des Kapitels 'Forschungen' betrachtet (1993), ${ }^{93}$ Jordan finds that this

\footnotetext{
${ }^{86}$ H. Wysling. "Der Zauberberg - als Zauberberg”, in T. Sprecher (ed.). Das Zauberberg Symposium, op. cit., pp. 43-58.

87 T. J. Reed, op. cit.

${ }^{88}$ M. Dierks. Studien zu Mythos und Psychologie bei Thomas Mann, op. cit., pp. 124-26.

89 H. Koopmann. "Philosophischer Roman oder romanhafte Philosophie? Zu Thomas Manns Lebensphilosophischer Orientierung in den zwanziger Jahren”, op. cit., pp. 79-80.

${ }^{90}$ H. Wysling. “Der Zauberberg - als Zauberberg”, op. cit., p. 55.

91 T. J. Reed, op. cit., p. 116.

92 K. Smikalla. Die Stellung Thomas Manns zur Romantik. Würzburg: Dissertation Julius-MaximiliansUniversität, 1953.

93 S. Jordan. Das Organische zwischen Naturwissenschaft und Mystizismus. Thomas Manns 'Zauberberg' aus der Perspektive des Kapitels 'Forschungen' betrachtet. Berlin: Wissenschaftliche Hausarbeit zur Ersten (Wissenschaftlichen) Staatsprüfung für das Amt des Studienrats, 1993. Georg Wenzel's investigation of 
chapter section modifies Schopenhauer's metaphysics to include Novalis's erotic mysticism and Nietzsche's concept of Dionysian intoxication. The significance of ideas and concepts proposed by Nietzsche, Schopenhauer and Freud in Thomas Mann's work is explored by Manfred Dierks in his book chapter "Thomas Manns Verhältnis zur Psychoanalyse" (1972), ${ }^{94}$ as well as by Hans Wysling in the essay "Thomas Manns Rezeption der Psychoanalyse" (1983). ${ }^{95}$ Dierks concludes that the work of Schopenhauer and Nietzsche forms the philosophical base of Der Zauberberg, followed by Freud (and Goethe), ${ }^{96}$ and that the novel utilises Freud's ideas in order to modernise those of Schopenhauer and Nietzsche. ${ }^{97}$ Wysling also notes the similarities between the drive theories of Schopenhauer, Nietzsche and Freud, ${ }^{98}$ observing in passing that both Hans Castorp (from Der Zauberberg) and Felix Krull's biological studies reflect a combination of Schopenhauer's metaphysics and Freud's psychology. ${ }^{99}$ In addition, Wysling mentions the connection between Novalis, Schopenhauer, Nietzsche and Freud in Mann's essay “Die Stellung Freuds in der modernen Geistesgeschichte". ${ }^{100}$ Dierks goes into more detail, claiming that Thomas Mann's reception of Novalis and Nietzsche led to his description of Freudian psychoanalysis in this essay as "Naturwissenschaft gewordene Romantik"; 101 furthermore, Dierks notes the assimilation of Novalis's ideas within the representation of Schopenhauer's Will in Der Zauberberg. ${ }^{102}$

\footnotetext{
Thomas Mann's general work in the context of Novalis also includes the discussion of Schopenhauer and Freud, yet he separates these influences into pairs, investigating first Novalis and Schopenhauer, and then Novalis and Freud. By so doing he neglects the overarching relationship between them (G. Wenzel. Novalis in den Anschauungen von Ricarda Huch, Thomas Mann und Hermann Hesse. Texte aus dem Novalis-Schloß, vol. 2. Schloß Oberwiederstedt: Janos Stekovics, 1997).

${ }^{94}$ M. Dierks. Studien zu Mythos und Psychologie bei Thomas Mann, op. cit., pp. 127-68.

${ }^{95}$ H. Wysling. "Thomas Manns Rezeption der Psychoanalyse”, op. cit.

${ }^{96}$ M. Dierks. Studien zu Mythos und Psychologie bei Thomas Mann, op. cit., pp. 128-29.

${ }^{97}$ Ibid., p. 137.

${ }^{98}$ H. Wysling. “Thomas Manns Rezeption der Psychoanalyse”, op. cit., pp. 208-09.

${ }^{99}$ Ibid., p. 210.

${ }^{100}$ Ibid., p. 209.

${ }^{101}$ M. Dierks. Studien zu Mythos und Psychologie bei Thomas Mann, op. cit., p. 147.

${ }^{102}$ Ibid., p. 146.
} 
Dierks' and Wysling's studies mentioned above are the only source-critical texts identified that examine the interrelation of all four thinkers in Mann's work. This obvious lack is addressed by the present study, which is the first to examine this particular constellation in depth, and the first to investigate it in the context of Der Zauberberg. The use of intertextual theory in the analysis of Der Zauberberg and its relation to the work of Novalis, Schopenhauer, Nietzsche and Freud is also unique to the present thesis: this configuration has been wholly ignored by intertextual scholarship to date.

\subsection{Models of intertextuality: text and intertext}

Intertextuality can be defined simply as the way in which a text's meaning is shaped by its relation to other texts. The French literary scholar, semiotician and psychoanalyst Julia Kristeva coined the term in 1967, describing the text in her essay "The Bounded Text" as "a permutation of texts, an intertextuality: in the space of a given text, several utterances, taken from other texts, intersect and neutralize one another". ${ }^{103}$ Yet Kristeva's concept of intertextuality is indebted to other thinkers, particularly to the Russian literary theorist and sociologist Mikhail Bakhtin, who defines language as monologic or dialogic (containing single or multiple meanings). ${ }^{104}$ In Bakhtin's view, the novel is a literary form in which dialogic language flourishes; ${ }^{105}$ this contrasts the static monologic language of the other genres. ${ }^{106}$ Kristeva's concept of intertextuality as a dialogue between texts applies the intratextual idea proposed by Bakhtin that the dialogic novel is characterised by an "internal polemic with the other" ${ }^{\prime 107}$ to the consideration of intertextual relationships. ${ }^{108}$

\footnotetext{
103 J. Kristeva. "The Bounded Text", in Desire in Language. New York: Columbia University Press, 1980, pp. 36-63, here, p. 36.

${ }^{104}$ G. Allen, op. cit., p. 10. Another important influence on Kristeva was the French linguist and semiotician Ferdinand de Saussure, who argues that meaning is produced by the relation of signifier to other signifiers (words to each other) rather than signifier to signified (words to their objects); intertextual theory shifts this linguistic web to a textual level (ibid.).

${ }^{105}$ M. M. Bakhtin. "Discourse in the Novel”, op. cit., p. 261.

${ }^{106}$ M. M. Bakhtin. "Epic and Novel”, op. cit., p. 49.

${ }^{107}$ M. M. Bakhtin. Problems of Dostoyevsky's Poetics. C. Emerson (transl. and ed.). Minneapolis: University of Minnesota Press, 1999, p. 228. Also quoted in G. Allen, op. cit., p. 25, and in M. Pfister. "Konzepte der Intertextualität", in U. Broich and M. Pfister (eds.). Intertextualität. Formen, Funktionen, anglistische Fallstudien. Tübingen: Max Niemeyer Verlag, 1985, pp. 1-30, here, p. 2.

108 This is not wholly intentional: in her essay on Bakhtin "Word, Dialogue, and Novel", Kristeva misinterprets Bakhtin's intratextual dialogism as intertextual, "an absorption of and [...] reply to another text"
} 
Kristeva also expands Bakhtin's concept of dialogism as specific to the novel to make all texts intertextual. ${ }^{109}$ This broad definition of the intertextual text has been adopted by poststructuralists including Roland Barthes, who defines the text as "a tissue of quotations drawn from the innumerable centres of culture"; ${ }^{110}$ similarly, Charles Grivel uses the term "texte général" to describe the sum of all texts plus their codes and meaning systems inscribed, however faintly, within every text. ${ }^{111}$ However, this poststructuralist definition of the intertext has largely remained theoretical due to the difficulty of applying it to analysis, ${ }^{112}$ and many literary theorists and analysts have instead chosen to work with a limited number of literary and non-literary intertexts. ${ }^{113}$ In her essay "Markierte Zitate und Kultur als Intertext: Varianten der Intertextualität in Thomas Manns Roman Königliche Hoheit", ${ }^{114}$ for example, Franziska Schößler conducts two complimentary analyses that use broad and narrow definitions of intertextuality. Although she follows Barthes' and Grivel's poststructuralist premise that the text is "[eine] Permutation der kulturellen Landschaft", 115 Schößler's first analysis actually focuses on only a few cultural intertexts: Max Weber's Die Protestantische Ethik und der Geist des Kapitalismus (1905) and Friedrich Nietzsche's critique of asceticism. ${ }^{116}$ The present study will similarly investigate intertextual links to a

(J. Kristeva. "Word, Dialogue, and Novel", in Desire in Language, op. cit., pp. 64-91, here, p. 69. See also P. Stocker. Theorie der intertextuellen Lektüre: Modelle und Fallstudien. München: Ferdinand Schöningh Verlag, 1998, p. 19; M. Pfister, op. cit., pp. 4-5; H. Herwig. "Literaturwissenschaftliche Intertextualitätsforschung im Spannungsfeld konkurrierender Intertextualitätsbegriffe", in R. Posner (ed.). Zeitschrift für Semiotik, vol. 24. Tübingen: Stauffenburg Verlag, 2002, pp. 163-76, here, p. 166.

${ }^{109}$ H. Herwig, op. cit., p. 166; M. Pfister, op. cit., p. 6.

${ }^{110}$ R. Barthes. "The Death of the Author", in S. Heath (transl. and ed.). Image-Music-Text. New York: Hill and Wang, 1977, pp. 142-48, here, p. 146.

${ }^{111}$ M. Pfister, op. cit., p. 13; H. Herwig, op. cit., p. 167. Jacques Derrida and Michel Foucault also follow this open poststructuralist model of the text (H. Herwig, op. cit., p. 167), which is closely related to Bakhtin's following claim: "The living utterance [...] cannot fail to brush up against thousands of living dialogic threads, woven by socio-ideological consciousness around the given object of an utterance" (M. M. Bakhtin. "Discourse in the Novel", op. cit., p. 276; see also ibid., p. 293.

${ }^{112}$ M. Pfister, op. cit., p. 9; P. Stocker, op. cit., p. 26; C. Gremler, op. cit., p. 17.

${ }^{113}$ M. Pfister, op. cit., p. 14; G. Allen, op. cit., pp. 58, 148-49.

${ }^{114}$ F. Schößler. "Markierte Zitate und Kultur als Intertext: Varianten der Intertextualität in Thomas Manns Roman Königliche Hoheit", in R. Posner (ed.). Zeitschrift für Semiotik, vol. 24, op. cit., pp. 199-212.

${ }^{115}$ Ibid., p. 199.

${ }^{116}$ Schößler's broad intertextual reading establishes a connection between literature and sociology which clearly follows Bakhtin (see "Discourse in the Novel", op. cit.) although she does not acknowledge this. 
limited range of social, philosophical and psychological intertexts in the form of selected works by Novalis, Schopenhauer, Nietzsche and Freud.

Schößler's second analysis investigates connections between the primary text and Andrew Carnegie's collection of essays on economic success The Empire of Business (1902). Here, Schößler uses a narrower definition of the intertext she attributes to the intertextual theory of Gérard Genette, ${ }^{117}$ whose definition of the intertext is limited to literature and genre types, ${ }^{118}$ and who was the first literary theorist to design a mediating taxonomy of intertextuality. ${ }^{119}$ In this taxonomy, Genette divides intertextuality (which he himself terms transtextuality) into five sub-groups: Intertextuality (quotation and plagiarism of, as well as allusion to, other texts), architextuality (reference to genres or literary conventions), metatextuality (thematic reference), paratextuality (titles, prefaces, notes, reviews) and hypertextuality (reference to a text significant to the primary text). ${ }^{120}$ Genette's taxonomy has also been applied to the intertextual analysis of Thomas Mann's work by Michael Maar, who introduces Geister und Kunst: Neuigkeiten aus dem Zauberberg by referring to Der Zauberberg as "[ein] alexandrinisch geschichtetete[s] oder hypertextuelle[s] Werk[]". ${ }^{121}$

Genette defines a hypertext as a literary text that impacts on the meaning of the primary text. ${ }^{122}$ This heuristic use of intertextual theory to analyse single literary texts is essentially structuralist, and contrasts the poststructuralist view of the intertextual text as an explosion of meaning. ${ }^{123}$ Yet Genette's understanding of meaning occupies a middle

\footnotetext{
117 F. Schößler, op. cit., pp. 199-200. Schößler's other influences are Ulrich Broich and Manfred Pfister (Pfister is discussed below).

118 G. Allen, op. cit., pp. 140-41; M. Pfister, op. cit., pp. 13, 17-18; P. Stocker, op. cit., pp. 27-28. Laurent Jenny, Harald Bloom, Wolfgang Preisendanz, Klaus. W. Hempfer, Rolf Kloepfer and Peter Stocker are literary scholars who similarly limit the intertexts to literature and genre types (G. Allen, op. cit., pp. 140-41; M. Pfister, op. cit., pp. 13, 17-18; P. Stocker, op. cit., pp. 27-28), and Harald Bloom narrows the definition of the intertext further to poetics (M. Pfister, op. cit., p. 14).

${ }^{119}$ G. Genette. Palimpsests: Literature in the second degree. Nebraska: University of Nebraska Press, 1997 (originally published 1982).

${ }^{120}$ H. Herwig, op. cit., p. 168; M. Pfister, op. cit., p. 17; G. Allen, op. cit., pp. 97-115.

${ }^{121}$ M. Maar, op. cit., p. 14. Maar acknowledges in a footnote that this term hypertextual originates from Genette's taxonomy (ibid.).

${ }^{122}$ G. Allen, op. cit., p. 108.

123 Ibid., p. 66.
} 
ground: unlike the attempt of many structuralists to attach a definitive meaning to the primary text, ${ }^{124}$ Genette labels his system "open structuralism” in acknowledgement of the fluid and relational nature of meaning. ${ }^{125}$ Genette's conception of meaning can be traced to Bakhtin's dialogism and the related concepts of heteroglossia (multiple voices within one word, i.e. the character voice, within which the voice of the author or narrator who directs him/her is embedded) and double-voiced discourse (language that conveys two intentions, e.g. of character and author). ${ }^{126}$ According to Bakhtin, meaning is created by the dialogue between word and "other" and is therefore relative, an "In-Beziehung-Setzen". ${ }^{127}$ The present study adopts Genette and Bakhtin's understanding of fluid meaning-production by investigating how the relationship between Der Zauberberg and the intertexts contributes to the novel's meaning.

The view of the primary text as the heuristic centre of the intertextual web is shared by the intertextual theorist Peter Stocker (1998), ${ }^{128}$ whose own intertextual typology is loosely based on that of Genette. ${ }^{129}$ According to Stocker, a text is intertextual if it quotes, thematises, or imitates another text or texts (described as palintextuality, metatextuality, and hypertextuality), or alternately if it demonstrates, thematises, or imitates a literary archetype (examples of demotextuality, thematextuality and similtextuality). ${ }^{130}$ Another taxonomy with a heuristic focus has been designed by Manfred Pfister (1985), ${ }^{131}$ whose

\footnotetext{
${ }^{124}$ P. Rusterholz. "Vom 'Werk' zu Intertextualität der Stoffe: Friedrich Dürrenmatts Wandlung”, in R. Posner (ed.). Zeitschrift für Semiotik, vol. 24, op. cit., pp. 295-305, here, p. 296; G. Allen, op. cit., pp. 4, 97.

125 G. Allen, op. cit., p. 100.

${ }^{126}$ M. Pfister, op. cit., p. 3; G. Allen, op. cit., p. 29.

${ }^{127}$ M. M. Bakhtin. "Zur Methodologie der Literaturwissenschaft”, in R. Grübel (ed.). Die Ästhetik des Wortes. Frankfurt: Suhrkamp Verlag, 1979, pp. 349-57, here, p. 352, quoted in P. Stocker, op. cit., p. 24; see also M. M. Bakhtin. "Epic and Novel", op. cit., p. 30. Kristeva similarly understands meaning to be the result of a dynamic interplay of texts, "an intersection of textual surfaces rather than a point (a fixed meaning)" (J. Kristeva. "Word, Dialogue, and Novel", op. cit., p. 65).

${ }^{128}$ P. Stocker, op. cit., p. 46.

${ }^{129}$ Ibid., p. 49.

${ }^{130}$ Ibid., pp. 50-68. Stocker's typology mediates between the broad post-structuralist and narrow structuralist definitions of the text (H. Herwig, op. cit., p. 171). Peter Rusterholz consequently praises Stocker's model: "Die bisher beste Darstellung des Forschungsstandes und einen überzeugenden Versuch, bisherige Ansätze soweit wie möglich in eine Globaltheorie zu integrieren und in praktischen Fallanalysen anzuwenden, hat Peter Stocker vorgelegt." (P. Rusterholz, op. cit., p. 297)
}

${ }^{131}$ M. Pfister, op. cit. 
intertextual criteria function uniquely as scales of intertextual intensity. Thus, Pfister's criterion of referentiality describes how strongly the text uses the intertext thematically. His criterion of communicativity addresses how clearly the text indicates the presence of the intertext, as well as how aware the author and/or the reader are of the intertextual relation. Autoreflexivity addresses to what degree the text "self-consciously" refers to its own intertextuality. ${ }^{132}$ Structurality denotes to what extent the text's structure follows that of the intertext, selectivity refers to how strongly the text stresses specificities of the intertext, and dialogicity denotes how strongly the intertext's original and new contexts clash on a semantic and ideological level. ${ }^{133}$ This last criterion of dialogicity is indebted to Bakhtin's concept of novelistic dialogism ${ }^{134}$ and its transference by Kristeva to an intertextual plane. ${ }^{135}$ However, Pfister's criteria is also an original contribution to scholarship, since by incorporating intertextual dialogism into his typology he facilitates the application of Kristeva's theoretical idea in practical literary analysis. In Faszination des Verfalls: Thomas Mann und Oswald Spengler, Barbara Beßlich examines structural concurrences between Der Zauberberg and Oswald Spengler's Der Untergang des Abendlandes according to Pfister's criterion of structurality. She concludes that both texts belong to the genre of the intellectual novel, and also blend fiction with scientific discourse. ${ }^{136}$ In addition, Beßlich uses Pfister's criterion of selectivity to investigate how strongly the primary text stresses individual elements from Der Untergang des Abendlandes, finding that the pre-World War I society represented in the novel strongly reflects the characteristics of Spengler's Endzeit. ${ }^{137}$

The typologies of Stocker and Pfister and their heuristic focus are an ideal basis for the present study. The literary theorist Henriette Herwig considers Stocker's and Pfister's typologies to be compatible; ${ }^{138}$ the present thesis realises her idea by adopting a selection

\footnotetext{
${ }^{132}$ Autoreflexivity is a particular characteristic of postmodern and some modern literature.

${ }^{133}$ M. Pfister, op. cit., pp. 26-30.

${ }^{134}$ M. M. Bakhtin. "Discourse in the Novel”, op. cit., p. 275.

135 J. Kristeva. "Word, Dialogue, and Novel”, in Desire in Language, op. cit., pp. 64-91, here, p. 69.

${ }^{136}$ B. Beßlich, op. cit., p. 54.

137 Ibid, pp. 57-58.

${ }^{138}$ H. Herwig, op. cit., p. 171.
} 
of criteria from both. Omitting Stocker's criteria that relate to genre, I focus on the textual criteria of metatextuality, where the text reflects themes from the intertext, and palintextuality, where the text quotes the intertext. To these I add Pfister's criteria of referentiality, communicativity, selectivity and dialogicity. Particularly interesting for this thesis is Pfister's dialogicity, which measures the heuristic tension between the primary text and the intertexts. ${ }^{139}$ This concept is reworked by the theorist Linda Hutcheon, who argues in A Theory of Parody that, whereas quotations confirm the intertext's meaning, irony and parody "mark difference". ${ }^{140}$ Hutcheon's idea concurs with Claudia Gremler's concept of the "Affirmation vs. Destruktion" of the intertext's original meaning within the primary text. ${ }^{141}$ I apply these ideas within my analysis, and also investigate the dialogic effect of trans-contextualisation; this aligns my concept of intertextual meaning with that of Stocker, who views intertextuality as a process in which primary text and intertext inadvertently "miteinander 'in Dialog' treten". ${ }^{142}$ In addition, my study concurs further with Gremler's definition of intertextuality by examining the dialogue not only between primary text and intertext, but also between the intertexts. ${ }^{143}$

\subsection{Author, reader, text: the origin of meaning production}

The traditional view of the author as the origin of meaning is challenged by poststructuralists. In his essay "The Death of the Author", Barthes demonstrates that the multiplicity of discourses (ways of speaking or writing) in Balzac's novella Sarrasine transcends the author's intention. ${ }^{144}$ Similarly, Harold Bloom argues in The Anxiety of Influence that is it impossible for an author to intend an intertextual connection because

\footnotetext{
139 Beßlich also investigates Der Zauberberg using Pfister's criterion of dialogicity (B. Beßlich, op. cit., p. 55).

${ }^{140}$ L. Hutcheon. A Theory of Parody. The Teachings of Twentieth-Century Art Forms. New York: Methuen, 1985 , p. 64.

${ }^{141}$ C. Gremler, op. cit., p. 24.

${ }^{142}$ P. Stocker, op. cit., p. 99.

${ }^{143}$ C. Gremler, op. cit., pp. 24-25.

${ }^{144}$ R. Barthes, op. cit.; see also G. Allen, op. cit., pp. 12-13.
} 
writing simply repeats works and ideas engrained in culture. ${ }^{145}$ This de-emphasis of the author is accompanied by an accentuation of the text; ${ }^{146}$ thus, Michael Riffaterre considers the text to be "self-sufficient", steering its own interpretation by alerting the reader to the presence of the intertexts. ${ }^{147}$ The independence of the text from the author renders the author's intention to incorporate an intertextual relation irrelevant, ${ }^{148}$ and unintended intertextual parallels become a valid subject of intertextual analysis. Herwig consequently argues for the acknowledgement of intertextual connections that allude to "[einem] unbewusste[n] Bestandteil des kulturellen Wissens des Verfassers und seiner Prägung durch die Diskursformation seiner Zeit". ${ }^{149}$ This argument is upheld in the context of Thomas Mann's work by Mann himself, who claimed in 1944 to have assimilated some of Freud's ideas indirectly. ${ }^{150}$

Postcolonialist and feminist literary theorists object to the poststructuralist emphasis on the text, arguing instead for the reinstatement of the author at the centre of meaning-production. Nancy K. Miller puts the case for the author thus:

[W] hen a theory of the text called 'hyphology' [hyphology = spider's web, Miller's name for intertextuality] chooses the spider's web over the spider; and the concept of textuality called the 'writerly' chooses the threads of lace over the lacemaker [...] the subject is self-consciously erased by a model of text production which acts to foreclose the question of agency itself. ${ }^{151}$

\footnotetext{
${ }^{145}$ G. Allen, op. cit., pp. 137-39. Michael Riffaterre similarly works from the premise that a text's meaning is a transformation of social discourse (the "sociolect") (ibid., p. 119).

146 J. Kristeva. “The Bounded Text”, op. cit., p. 36; H. Herwig, op. cit., p. 167; M. Pfister, op. cit., p. 8; G. Allen, op. cit., p. 28.

147 M. Riffaterre. "Compulsory reader response: the intertextual drive”, in M. Worton and J. Still (eds.). Intertextuality: Theories and Practices. Manchester: Manchester University Press, 1990, pp. 56-78, here, pp. 58, 61; G. Allen, op. cit., p. 130.

${ }^{148}$ M. Pfister, op. cit., p. 22.

${ }^{149}$ H. Herwig, op. cit., p. 169.

${ }^{150}$ See the introduction, p. xi. H. Wysling (ed.). Thomas Mann. Selbstkommentare: Der Zauberberg, op. cit., p. 142; F. J. Beharriell, op. cit., p. 5.

${ }^{151}$ N. K. Miller. Subject to Change: reading feminist writing. New York: Columbia University Press, 1988, p. 80, quoted in G. Allen, op. cit., p. 156.
} 
Structuralists similarly value the "agent" of the author-subject, and consequently place greater emphasis on intended intertextual references. ${ }^{152}$ However, this emphasis on authorintention is criticised as restrictive by Herwig and Stocker, who regard both intended and unintended intertextual connections as valid. ${ }^{153}$ The present thesis attempts to amalgamate these contrasting views. I primarily investigate intertexts written prior to the publication of Der Zauberberg, an angle which assumes the importance of the author's working knowledge of the intertext, if not intentional insertion of intertextual references. The present study thereby loosely follows the structuralist concepts of "pre-text" (intertext) and "post-text" (primary text). ${ }^{154}$ However, I also investigate unintended intertextual parallels, following my conviction that these also contribute to the primary text's meaning.

Intertextual "marking" is another bone of contention among literary theorists. Pfister's criterion of communicativity measures how clearly the presence of the intertext is indicated by the text. This marking may or may not reflect the author's intention. In an example of intentional marking, Beßlich concludes (using Pfister's communicativity) that intertextual parallels in Der Zauberberg are often signalled by irony, a form of doublevoiced discourse that incorporates the author's voice. ${ }^{155}$ However, whereas Stocker considers marking to be a prerequisite for intertextuality, ${ }^{156}$ Schößler argues that it is not essential. ${ }^{157}$ Once again, I assume a mediating stance, focusing on clearly marked intertextual relations in my study of Der Zauberberg, but acknowledging unmarked connections where they arise.

Stocker's emphasis on marking follows his belief that the text is at the centre of meaning production. Yet this emphasis on the text differs from the post-structuralist view

\footnotetext{
152 M. Pfister, op. cit., pp. 22-23; H. Herwig, op. cit., p. 169. This preference for intentionally placed intertextual references is illustrated by Gremler (C. Gremler, op. cit., p. 19).

${ }^{153}$ H. Herwig, pp. 169, 170-71; P. Stocker, op. cit., p. 9.

${ }^{154}$ This contrasts the poststructuralist concept of the intertext as part of a web of meaning independent of the era in which the primary text was written (see M. Pfister, op. cit., p. 13).

${ }^{155}$ B. Beßlich, op. cit., p. 108; see also M. M. Bakhtin. "From the Prehistory of Novelistic Discourse", in M. Holquist (ed.), C. Emerson and M. Holquist (transl.). The Dialogic Imagination. Four Essays by M. M. Bakhtin, op. cit., pp. 41-83, here, p. 76.

${ }^{156}$ P. Stocker, op. cit., pp. 102, 105. Gremler similarly concedes that marking may or may not be present (C. Gremler, op. cit., pp. 19).

${ }^{157}$ F. Schößler, op. cit., p. 200.
} 
discussed earlier because the presence of the author is acknowledged, albeit within the text. ${ }^{158}$ This concept of the author as a product of writing is illustrated by Stocker's analysis of Thomas Mann's Die vertauschten Köpfe, ${ }^{159}$ in which the narrator's (author's) apparent external position is unmasked as an illusion. ${ }^{160}$

According to his view of the text as primary, Stocker is convinced that the reader should only interpret marked intertextual connections. ${ }^{161}$ This restriction of the reader's role is challenged by Hutcheon, who regards intertextual forms other than parody as "mode[s] of perception", ${ }^{162}$ i.e. determined equally by the reader as by the text; ${ }^{163}$ similarly, Herwig calls for a synthesis of author-based, text-based and reader-based meaningproduction. ${ }^{164}$ The present study concurs with the views of these last theorists by approaching the analysis of Der Zauberberg from both author/text and reader perspectives.

Stocker divides the process of intertextual recognition into three phases: disintegration, digression, and reintegration. The first phase (disintegration), denotes the process by which the reader becomes aware of an intertextual connection. ${ }^{165}$ This textual "Kohärenz-Störung" is brought about primarily by the double-voicedness of the intertextual text, ${ }^{166}$ and corresponds to Hutcheon's description of irony as a strategy of discourse that "allows the decoder to interpret and evaluate". ${ }^{167}$ The second phase of Stocker's process of reader-interpretation (digression) describes the reader's journey away from the primary text to the specific intertext, and the final phase (reintegration) denotes

\footnotetext{
${ }^{158}$ P. Stocker, op. cit., p. 42. Hutcheon and Rusterholz similarly treat the author as a function within the text (L. Hutcheon, op. cit., p. 86; P. Rusterholz, op. cit., pp. 296-97).

${ }^{159}$ P. Stocker, op. cit., pp. 175-91.

${ }^{160}$ Ibid., pp. 179, 181.

${ }^{161}$ P. Stocker, op. cit., p. 9; P. Rusterholz, op. cit., p. 297. Quoting Director Behrens' exposition on the advantages of anatomical knowledge when depicting the human body, Maar argues that Thomas Mann invites the reader to analyse his work (M. Maar, op. cit., pp. 13-14); however, the somewhat arbitrary mass of intertextual associations in Maar's study negates Stocker's emphasis on intertextual marking.

${ }^{162}$ L. Hutcheon, op. cit., pp. 37-38, 87.

${ }^{163}$ Ibid., p. 24.

${ }^{164}$ H. Herwig, op. cit., p. 170.

${ }^{165}$ P. Stocker, op. cit., p. 104.

${ }^{166}$ Ibid., p. 13.

${ }^{167}$ L. Hutcheon, op. cit., p. 31.
} 
the reader's re-evaluation of the primary text in the context of the intertext. ${ }^{168}$ I plan to use Stocker's process of interpretation in the present study. My analysis is consequently divided into three steps: An exploration of Der Zauberberg and any intertextual marking present will be followed by a discussion of the relevant intertext and the investigation of its heuristic implications for the novel.

${ }^{168}$ P. Stocker, op. cit., p. 104. 


\section{Chapter 2. Death and life on the mountain}

\subsection{The social repression of death}

Thomas Mann's Der Zauberberg is set at a tuberculosis sanatorium in Davos, Switzerland. The plot plays out during the seven years prior to World War I (1907-1914), at a time before the development of vaccines and antibiotics effective against tuberculosis. This was the era in which sanatorium treatment was based on an open-air "rest cure", and in which tuberculosis patients were often subjected to a "pneumothorax" procedure, an operation that entailed partially incapacitating the diseased patients' lung in order to promote healing. The success rate of these treatments was not high: records from a British sanatorium show that $44 \%$ of patients admitted between 1907 and 1914 died, despite the fact that the institution was well-equipped, and the terminally ill were refused admission. ${ }^{169}$ These grim statistics are reflected in Der Zauberberg by the deaths of numerous characters during the course of the novel. The alpine sanatorium Berghof is thus a place of death, and is contrasted within the novel with the "Flachland" $(588)^{170}$ of general Europe "drunten im Leben" (91).

The hero, Hans Castorp, travels to sanatorium Berghof from his German home town of Hamburg to visit his cousin, Joachim Ziemßen, who has been diagnosed with tuberculosis. Joachim meets Castorp at the train station, ${ }^{171}$ and casually mentions during their walk to the sanatorium that in winter, deceased patients from a sanatorium situated higher up the mountain are transported down to the local cemetery in bobsleds. Castorp reacts to this information with hilarity, and laughs until the tears run down his cheeks when Joachim continues by confiding that the assistant doctor, Dr Krokowski, psychoanalyses the patients. Castorp's semi-hysteria is in both cases a reaction of shock to the phenomenon of death. The initially hidden motivic connection between psychoanalysis and death is

${ }^{169}$ O. R. McCarthy. "The Key to the Sanatorium”, in Journal of the Royal Society of Medicine, vol. 94, no. 8. London: Sage Publications, 2001, pp. 413-17.

${ }^{170}$ Page numbers in brackets within the text refer to the following edition of Der Zauberberg: H. Detering, E. Heftrich, H. Kurzke, T. J. Reed, T. Sprecher, H. R. Vaget and R. Wimmer (eds.). Thomas Mann. Große Kommentierte Frankfurter Ausgabe. Werke - Briefe - Tagebücher, op. cit., vol. 5.1.

171 Although most characters in Der Zauberberg are referred to by their surname (e.g. Castorp, Settembrini and Naphta), Joachim Ziemßen is often referred to by his first name. My thesis reflects this idiosyncrasy. 
revealed in the chapter section "Freiheit" by a fellow patient, Ludovico Settembrini, who tells Castorp that psychoanalysis is "verwandt dem Grabe und seiner anrüchigen Anatomie" (338). ${ }^{172}$ Castorp's hysterical reaction to death continues after his arrival at the sanatorium when Joachim tells him that his room's previous occupant, an American woman, died only two days previously (23). On hearing this news, Castorp embarks on a disjointed monologue that repeats elements of what Joachim has just told him, while significantly omitting any references to death. Ignoring the contagion of tuberculosis, Castorp focuses on the sterilisation of the room with formalin; ignoring the grief of the American's betrothed, he chatters on about the man's shaving habits; finally shaking himself free of the topic by following an association with cigars, Castorp comes to a halt after passing on greetings to Joachim from acquaintances in Hamburg (23-24). His entire monologue seems to be an attempt to distract himself from the thought of death by focusing on trivialities.

Joachim subsequently retires to his own room to dress for dinner, after which the two cousins walk together in the direction of the sanatorium restaurant. On the way, Castorp is stopped in his tracks by the sound of coughing:

Es war Husten, offenbar, - eines Mannes Husten; aber ein Husten, der keinem anderen ähnelte, den Hans Castorp jemals gehört hatte, ja, mit dem verglichen jeder andere ihm bekannte Husten eine prächtige und gesunde Lebensäußerung gewesen war, - ein Husten ganz ohne Lust und Liebe, der nicht in richtigen Stößen geschah, sondern nur wie ein schauerlich kraftloses Wühlen im Brei organischer Auflösung klang. (25)

To Castorp, this sound is "gar kein lebendiger Husten" (25), i.e., it belongs to the realm of death, and his shock is evident from his repeated observation that "man förmlich dabei in den [Mann] hineinsehe" (25). Later that night, Castorp dreams that the same cough is emanating from the chest of Joachim, whom he sees, pale as a corpse and curiously disjointed, riding a bobsled down the mountain (33). Castorp reiterates his daytime

\footnotetext{
${ }^{172}$ Castorp reiterates Settembrini's idea in the chapter section "Vom Gottesstaat und von übler Erlösung" when he muses "über das doppelte Wesen der Analyse und wie weit sie der Tat und dem Fortschritte förderlich sei, wie weit dem Grabe verwandt und seiner anrüchigen Anatomie" (589). This link between psychoanalysis and death is explained by the nature of unconsciousness as distinct from consciousness (and from the latter's association with life).
} 
reactions to death in this dream, shedding bitter tears at the sight of Joachim that soon turn to laughter in a repetition of his hysteria while awake (33).

An explanation for Castorp's reaction of shock and hysteria on his arrival at the sanatorium is provided by the portrayal of Castorp's childhood in the chapter section "Von der Taufschale und vom Großvater in zwiefacher Gestalt”. It seems that Castorp was sheltered from the deaths of others as much as possible. Although his mother, father, and grandfather all died before he turned eight, he is only present at the death of his mother, who died suddenly from an embolism (34). Castorp is also shielded from the final illnesses of his father and grandfather, and is aware of his grandfather's dying "nur mittelbar, durch die beklommene Atmosphäre des Hauses, die roten Augen des alten Fiete, [und] das Anund Wegfahren der Doktoren" (45). This concealment of death and dying is also practised at sanatorium Berghof. As Joachim explains to Castorp, sanatorium protocol aims to screen the death of others as much as possible from the remaining patients:

[E]s geht im strengsten Geheimnis vor sich, wenn einer stirbt, aus Rücksicht auf die Patienten und namentlich auch auf die Damen, die sonst leicht Zufälle bekämen. Wenn neben dir jemand stirbt, das merkst du gar nicht. Und der Sarg wird in aller Frühe gebracht, wenn du noch schläfst, und abgeholt wird der Betreffende auch nur zu solchen Zeiten, zum Beispiel während des Essens. (83)

The sanatorium's strategy towards death is reflected in the patients' own "System der Verheimlichung, [...] [ein] Nichts-wissen-, Nichts-sehen-und-hören-Wollen” (442). This attitude leads to strong disapproval of anyone who brings attention to the subject of death. In the chapter section "Nr. 34", for example, Joachim criticises the deceased American's betrothed for having cried in the corridor as she lay dying (23). Similarly, Frau Stöhr is outraged when Castorp tries to start a conversation about the Austrian "Herrenreiter" (the owner of the dreadful cough) soon after the latter's demise:

Was ihm [Castorp] einfalle, von so etwas anzufangen, hatte sie [Frau Stöhr] gefragt, und was er denn eigentlich für eine Kinderstube genossen. Die Ordnung des Hauses schütze sie, die Patientenschaft, sorgfältig davor, von solchen Geschichten berührt zu werden, und da komme nun so ein Grünschnabel und rede ganz laut davon, noch dazu beim Braten und dazu wieder in Gegenwart des Dr. Blumenkohl, den es täglich ereilen könne. (442) 
This aversion to the subject of death both at the sanatorium and in Castorp's childhood is an intertextual "signal" that suggests the following intertext: Sigmund Freud's “Zeitgemäßes über Krieg und Tod”. In this essay, Freud discusses the repression of death in modern culture:

Wenn man uns anhörte, so waren wir natürlich bereit zu vertreten, daß der Tod der notwendige Ausgang alles Lebens sei, daß jeder von uns der Natur einen Tod schulde und vorbereitet sein müsse, die Schuld zu bezahlen, kurz, daß der Tod natürlich sei, unableugbar und unvermeidlich. In Wirklichkeit pflegten wir uns aber zu benehmen, als ob es anders wäre. Wir haben die unverkennbare Tendenz gezeigt, den Tod beiseite zu schieben, ihn aus dem Leben zu eliminieren. ${ }^{173}$

The metatextual connection (in the language of Stocker) between this passage and Der Zauberberg is highly selective and referential (in the language of Pfister). Knowledge of Freud's text alters the reader's interpretation of the novel and enriches its meaning by suggesting that the concealment of death in Hamburg and at sanatorium Berghof, and Hans Castorp's reactions of shock and hysteria, illustrate a tendency to avoid the subject of death in early $20^{\text {th }}$-century European culture.

The repression of the theme of death in Der Zauberberg can be linked to anxiety caused by the atheist concept of death as a mere absence of life. ${ }^{174}$ This view of death is presented in the chapter section "Forschungen", in which Castorp's biology textbook teaches him that death is "die logische Verneinung des Lebens" (416). Castorp's reading clearly relates metatextually to the work of Nietzsche and Freud. Nietzsche, for example, claims: "[D]er Tod [ist] nichts anderes als bloße Abwesenheit des Lebens", ${ }^{175}$ an idea that anticipates Freud's description of death in "Zeitgemäßes über Krieg und Tod” as "[die] Aufhebung des Lebens". ${ }^{176}$

In the chapter section "Als Soldat und brav", the concept of death as the absence of life is developed by the narrator, who describes death as something essentially "other":

\footnotetext{
${ }^{173}$ Freud X, p. 341.

174 The fear of death and its relation to atheism is discussed in depth in subchapter 2.3 (see pp. 36-41).

${ }^{175}$ Nietzsche KSA 8, p. 161.

${ }^{176}$ Freud X, p. 348.
} 
Tatsächlich ist unser Sterben mehr eine Angelegenheit der Weiterlebenden als unserer selbst; denn ob wir es nun zu zitieren wissen oder nicht, so hat das Wort des witzigen Weisen jedenfalls volle seelische Gültigkeit, daß, solange wir sind, der Tod nicht ist, und daß, wenn der Tod ist, wir nicht sind; daß also zwischen uns und dem Tode gar keine reale Beziehung besteht und er ein Ding ist, das uns überhaupt nichts $[\ldots]$ angeht $[\ldots]$. (801)

The wise man referred to in this passage is Arthur Schopenhauer, who quotes and paraphrases the ancient Greek Epicurus in the second volume of Die Welt als Wille und Vorstellung: “[D]er Tod geht uns nichts an [...]. [W]ann wir sind, [ist] der Tod nicht [...], und wann der Tod ist, [sind] wir nicht". ${ }^{177}$ Thomas Mann's introduction of the narrator's palintextual reference (in the language of Stocker) as “das Wort des witzigen Weisen”, indicates not only his intention to quote Schopenhauer, but also his wish for the reader to identify the intertext. This makes the passage quoted above strongly communicative (in the language of Pfister).

Further relation to Schopenhauer's work in Der Zauberberg appears a few pages after the narrator's comments quoted above, when the sanatorium director, Director Behrens, also refers to death as something "other" in a conversation with Joachim's mother:

Wir kommen aus dem Dunkel und gehen ins Dunkel, dazwischen liegen Erlebnisse, aber Anfang und Ende, Geburt und Tod, werden von uns nicht erlebt, sie haben keinen subjektiven Charakter, sie fallen als Vorgänge ganz ins Gebiet des Objektiven, so ist es damit. (809)

Behrens' words correspond referentially and selectively to the following passage from Die Welt als Wille und Vorstellung: “[D]ie Zeit, da ich nicht sein werde, wird objektiv kommen, aber subjektiv kann sie nie kommen". ${ }^{178}$ However, the otherness of death in Der Zauberberg also relates to the work of Nietzsche and Freud. In the first volume of

${ }^{177}$ Schopenhauer II, p. 597. References within this thesis to Schopenhauer I-V concern the following edition: W. Frhr. von Löhneysen (ed.). Arthur Schopenhauer. Sämtliche Werke, vols. I-V. Stuttgart/Frankfurt am Main: Suhrkamp Verlag, 1986.

178 Schopenhauer II, p. 622. Behrens' statement also relates to Schopenhauer's description of birth and death delineating life from the unknown (ibid., pp. 540-42, 626; see also Nietzsche KSA 8, p. 161). In Der Zauberberg, the shared identity of birth and death is humorously portrayed in Castorp's treatment of dying patients as if they were birthday boys and girls in the chapter section "Totentanz" $(455-56,460)$. 
Menschliches, Allzumenschliches, Nietzsche describes the metaphysical world as "ein uns unzugängliches, unbegreifliches Anderssein; [..] ein Ding mit negativen Eigenschaften". ${ }^{179}$ In the essay "Zeitgemäßes über Krieg und Tod", Freud similarly presents death as "unvorstellbar", given that an attempt to visualise death inevitably turns the subject into a witness of the event, as if death were happening to someone else. ${ }^{180}$

The otherness of death leads Schopenhauer to conclude: "[D]er Tod [ist] ein Mysterium". ${ }^{181}$ Yet this statement is subtly different to the concept of death as other (see above), which is rooted in the atheist view of death as the absence of life. Instead, Schopenhauer's conclusion relates to the Christian concept of death as a holy mystery. ${ }^{182}$ This view of death is reflected in Novalis's claim, from "Das allgemeine Brouillon" (1798/99), that the deceased person is "ein in abs[oluten] Geheimnißzustand erhobener Mensch". ${ }^{183}$ In Der Zauberberg, the mysterious nature of death is challenged by rational, scientific thought. In the chapter section "Operationes spirituales", for example, Settembrini declares that death is "eine eindeutige, vernünftige, physiologisch notwendige [...] Erscheinung" (690). The theme of death's transparency is also associated in the novel with Dr Krokowski's psychoanalysis, which is described as “[eine] Durchleuchtung des Unbewußten" (198). Parallels between the unconscious mind (examined by psychoanalysis) and death are drawn in Der Zauberberg when Settembrini dubs Krokowski "Minos" (90) (one of the judges of the dead in Hades). In addition, the doctor's

\footnotetext{
${ }^{179}$ Nietzsche KSA 2, p. 29.

${ }^{180}$ Freud X, p. 314. Freud's idea is indebted to Schopenhauer's following description of the inability of the subject to perceive itself: "[M]ein eigenes Wesen [ist] das Erkannte [...]: den sofern es in mein erkennendes Bewußtsein fällt, ist es schon ein Reflex meines Wesens, ein von diesem selbst Verschiedenes" (Schopenhauer II, p. 632).

${ }^{181}$ Schopenhauer II, p. 631.

182 Thus, Randall W. Gibson begins the abstract of his doctoral dissertation in theology with the following statement: "Death is not a problem to be solved. Rather, death is a mystery." (R. W. Gibson. The Mystery of Death: Toward a Pacifist Ethic. Cambridge: ProQuest UMI Dissertations Publishing, 2008, p. vi). For further comparisons of Schopenhauer's ideas with Christian dogma, see 2.3, pp. 37, 39-40; 2.4, pp. 41-42, 47.

${ }^{183}$ Novalis 3, p. 290; also quoted in K. Hamburger, op. cit., p. 45. The unknowableness of death is also reflected in "[den] unendliche[n] Geheimnisse[n]" depicted by Novalis in his second "Hymne an die Nacht" (Novalis 1, p. 135; see also ibid., p. 143). The references to Novalis 1-4 in this thesis concern the following edition: P. Kluckhohn and R. Samuel (eds.). Novalis Schriften. Die Werke Friedrich von Hardenbergs, vols. 1-5. Stuttgart: W. Kohlhammer, 1983. Novalis was writing before the standardisation of German spelling; any inconsistencies of spelling within this thesis (for example both "Krankheit" and "Kranckheit") are faithful reproductions of the original.
} 
"phosphoreszierende[] Blässe", "gelbliche[] Zähne", and "die dunkle Glut seiner Augen" (30) suggest the appearance of a corpse. ${ }^{184}$

Psychoanalysis and its relation to the scrutiny of death's mystery is criticised in the novel as immoral. This is clear from Joachim's following declaration: “[D]ann und wann erzähl' ich ihm [Krokowski] einen Traum, damit er was zu zergliedern hat" (32). Further compounding the immorality of psychoanalysis, Krokowski is described as a "Rattenfänger" (199), ${ }^{185}$ who not only has a devilishly forked beard (30) but is also introduced to the reader with the following devilish (English) pun: "Dr. Krokowski saß im Hellen" (30). The use of religious metaphor in conjunction with the criticism of psychoanalysis calls to mind the text Jenseits von Gut und Böse, in which Nietzsche declares the existence of "heilige[n] Erlebnisse[n] [...], vor denen [man] die Schuhe auszuziehn und die unsaubre Hand fernzuhalten hat". ${ }^{186}$ "Modern" intellectuals, Nietzsche continues, completely lack appropriate reverence: "[Es wirkt] vielleicht nichts so ekelerregend als ihr Mangel an Scham, ihre bequeme Frechheit des Auges und der Hand, mit der von ihnen an Alles gerührt, geleckt, getastet wird". ${ }^{187}$ Although this text is related in Der Zauberberg to a theme contrary to Nietzsche's view of death as the simple absence of life (discussed above), the outrage at modern dissection expressed by Nietzsche is completely concordant with Anton Karlowitsch Ferge's horror, related in the chapter section "Totentanz", at feeling a surgical instrument (held by Director Behrens) touching the inside of his body:

\footnotetext{
${ }^{184}$ In addition, Krokowski's clinical room is a gloomy chamber (205) reached by descending "zwei Stufen von der Höhe des Flurganges hina[b]" (204).

${ }^{185}$ The negative portrayal of psychoanalysis in Der Zauberberg reflects Thomas Mann's personal reaction to Freud's psychoanalytic theory. A notebook entry from 1916 in response to Freud's essay "Zeitgemäßes über Krieg und Tod" reads: "Freud fortschrittlich-zersetzend; wie alle Psychologie. Die Kunst wird unmöglich, wenn sie durchschaut ist. Er wirkt für den Geist" (H. Wysling and Y. Schmidlin (eds.). Thomas Mann. Notizbücher 7-14, vol. 2, op. cit., p. 269). In 1925, Thomas Mann also used the analogy of the X-ray to describe psychoanalysis negatively: "Wird doch der Künstler von Freuds Ideen wie von einem Bündel XStrahlen durchleuchtet, und das bis zur Verletzung des Geheimnisses seiner Schöpfertat." (Mann. Interview from May 1925 with the Turin Stampa, quoted in H. Wysling. "Thomas Manns Rezeption der Psychoanalyse", op. cit., p. 206, and in H. Sauereßig, op. cit., p. 431).

${ }^{186}$ Nietzsche KSA 5, p. 218.

${ }^{187}$ Ibid.
} 
Das Rippenfell, meine Herren, das soll nicht berührt werden, das darf und will nicht berührt werden, das ist tabu, das ist mit Fleisch zugedeckt, isoliert und unnahbar, ein für allemal. Und nun hatte er [Behrens] es bloßgelegt und tastete es ab. Meine Herren, da wurde mir übel. (470) ${ }^{188}$

The immoral scientific probing of the body described in this passage is aligned with the theme of death in the chapter section "“Mein Gott, ich sehe!"”, in which Hans Castorp is shaken by the sight of Joachim's skeleton and heart projected onto the x-ray screen:

Heftig bewegt von dem, was er sah, oder eigentlich davon, daß er es sah, fühlte er sein Gemüt von geheimen Zweifeln gestachelt, ob es rechte Dinge seien, mit denen dies zugehe, Zweifeln an der Erlaubtheit seines Schauens im schütternden, knisternenden Dunkel [...]. (332)

The $\mathrm{x}$-ray shows bones without flesh, and is thus a visual parable for death. By criticising the attempt of science to probe into the mystery of death, this passage infers that death should remain a mystery. The x-ray of Hans Castorp's own hand at the end of the chapter section is as such something "[d]as [...] eigentlich dem Menschen zu sehen nicht bestimmt ist" (333).

Yet why should the mystery of death be defended? The discussion in the previous paragraphs suggests that the negative portrayal of scientific analysis in Der Zauberberg is a tacit criticism of atheism and its conception of death as the absence of life. Considering Thomas Mann's own dislike of organised religion, ${ }^{189}$ this apparent rejection of atheism in favour of a Christian conception of death in the novel illustrates a clash between authorial and narrative viewpoints. ${ }^{190}$ Nevertheless, a degree of double-voiced discourse, where the authorial view is imbedded within the character view, or in this case, within the narrative, ${ }^{191}$ allows the dominance of the Christian concept of death in the passages examined above to

\footnotetext{
${ }^{188}$ Ferge's experience also borrows Nietzsche's use of religious metaphor when he compares his operation to being in hell (471).

189 See W. Frizen. "Thomas Mann und das Christentum” in H. Koopmann (ed.). Thomas Mann Handbuch, op. cit., pp. 307-26, here, p. 307; Mann 13.1, pp. 582-83.

${ }^{190}$ See M. M. Bakhtin. Problems of Dostoyevski's Poetics, op. cit., pp. 47-75; see also M. M. Bakhtin. "Discourse in the Novel", op. cit., p. 287.

${ }^{191}$ See M. M. Bakhtin. "Discourse in the Novel", op. cit., p. 324.
} 
be understood in terms of Mann's influence by Romantic philosophy. The following section will investigate the (Romantic) Christian and atheist interpretations of death in more detail.

\subsection{Views of death: Christian versus atheist}

The nature of death has been a subject of debate for millennia. In recent history, the emergence of the physical and biological sciences during the period of the Enlightenment allowed the domination of mediaeval church dogma to be called into question, opening the way for new approaches to deism as well as for agnosticism and atheism. ${ }^{192}$ However, a backlash against Enlightenment thought during the Romantic period saw the widespread reinstatement of conservative forms of Christianity. ${ }^{193}$ The consequent clash between (Classical) atheism and (Romantic) Christianity is explored in Der Zauberberg in debates between the humanist Ludovico Settembrini and the Jesuit Leo Naphta. ${ }^{194}$

On an excursion from sanatorium Berghof to the neighbouring alpine village, Hans Castorp and Joachim come across their acquaintance Settembrini deep in conversation with a stranger. Introduced as Leo Naphta, this small Jesuit "[von] ätzender Häßlichkeit” (5623 ) is ideologically opposed to Settembrini's Classical worldview, and as the men continue their walk towards the village, Settembrini inadvertently triggers a debate about the concepts of Nature and Mind when he praises the alpine spring weather for "[seine] Klarheit, Trockenheit, Heiterkeit und herbe Anmut" (564). Naphta accuses Settembrini of artificially imposing Classical ideals (in this case, Mind) onto nature, whereupon Settembrini retorts that nature is "selber Geist" (565). Settembrini's statement suggests a monist belief in an animating force within nature itself, and thus corresponds referentially to Schopenhauer's concept of the Wille (Will), a force for life present in all living things that substitutes the concepts of both soul and God. ${ }^{195}$ Settembrini's unification of Nature

\footnotetext{
192 P. Watson. The German Genius. London: Simon \& Schuster UK Ltd, 2011, pp. 65-88.

193 A. E. McGrath. Christian Theology: An Introduction. Chichester: Wiley-Blackwell, 2011, pp. 67-70.

194 As an example of the conservative religious movement within the $19^{\text {th }}$ century, Róisín Healy notes the revival of the Jesuit Order (Naphta's Order) (R. Healy. The Jesuit Spectre in Imperial Germany. T. Brady and R. Chickering (eds.). Studies in Central European Histories. Boston: Brill Academic Publishers, inc., 2003, p. 51).

195 Thus, Schopenhauer writes: "Bei mir ist das Ewige und Unzerstörbare im Menschen [...] der Wille" (Schopenhauer III, pp. 339-40).
} 
and Mind also concurs with Nietzsche's view of the mind as a form of metabolism (i.e. as a biological function) in Ecce Homo, ${ }^{196}$ as well as with Schopenhauer's description in Die Welt als Wille und Vorstellung of the intellect as "[eine] Funktion des cerebralen Nervensystems". ${ }^{197}$ These texts arguably inform Freud's view of consciousness as a function of the brain in "Jenseits des Lustprinzips". ${ }^{198}$ The intertextual relationship between these scientific texts discussed above and Der Zauberberg influences the reader's interpretation of the novel by suggesting that Settembrini's ideological opposition to Naphta is based on an atheist rejection of Christianity.

Indeed, Naphta's own division between Nature and Mind reflects a Christian separation of world and God, body and immortal soul. ${ }^{199}$ Thomas Mann traces this belief system to Novalis in the speech "Von deutscher Republik" ("[c]hristlicher Weise reißt er Gott und Natur auseinander"), ${ }^{200}$ and it is therefore arguable that Mann modelled Naphta's views on those of the philosopher poet. ${ }^{201}$ The reader's recognition of an intertextual link between Naphta's views and Novalis's work leads him or her to interpret Naphta's position as fundamentally Romantic, and the opposition between Naphta's Christian dualism and Settembrini's atheistic monism is consequently clarified as a clash between Romantic and Classical ideologies. ${ }^{202}$

Naphta's Romantic, Christian conception of the world is dialogically opposed to Nietzsche's rejection of the Christian opposition of body and soul in Die Geburt der

\footnotetext{
${ }^{196}$ Nietzsche KSA 6, p. 282.

197 Schopenhauer II, p. 639.

198 Freud XIII, p. 23.

199 This duality of body and soul is illustrated in Der Zauberberg by the impression young Castorp has of his dead grandfather: "[W]as da lag, war also nicht der Großvater selbst, sondern eine Hülle, die [...] nicht aus Wachs bestand, sondern aus ihrem eigenen Stoff; nur aus Stoff' (47). Castorp's impression stresses the essential separateness of the soul from the body by implying the former's absence in death.

${ }^{200}$ Mann 15.1, p. 545.

${ }^{201}$ In fact, Novalis is concerned with reconciling these opposites, as will be discussed in subchapter 6.5 (see pp. 210-17).

${ }^{202}$ Käte Hamburger sums up the Classical and Romantic conceptions of death as follows: "Der Tod ist für die Klassik ein dem Leben immanentes Phänomen, durch das die Form des Lebens sich in sich vollendet. Aber für die Romantik ist der Tod das transzendierende Prinzip des Lebens, durch das es über sich selbst hinaus in ein unendlich-ewiges verwandelt wird.” (K. Hamburger, op. cit., pp. 51-52)
} 
Tragödie, ${ }^{203}$ which he also expresses in Also sprach Zarathustra: "'Leib bin ich und Seele' - so redet das Kind. Und warum sollte man nicht wie die Kinder reden? Aber der Erwachte, der Wissende sagt: Leib bin ich ganz und gar, und nichts ausserdem; und Seele ist nur ein Wort für ein Etwas am Leibe." ${ }^{204}$ Similarly negating the duality of soul and body (Mind and Nature), Settembrini's relation of these to life and death leads to his conviction that death is "Bedingung und Zubehör des Lebens" (620), the afterlife consequently absorbed "ins Diesseits" (602; see also 304). This concept of death as a phenomenon within life is developed in the chapter section "Humaniora", in which Director Behrens observes: "Tja, Leben ist Sterben, da gibt es nicht viel zu beschönigen" (404). Behrens' observation has been traced by Erkme Joseph to the following fragment by Nietzsche: "[D]as, was wir 'Leib' nennen [...] [ist] etwas Wachsendes, Kämpfendes, Sich-Vermehrendes und WiederAbsterbendes [...], und unser Leben [ist] wie jegliches Leben zugleich ein fortwährendes Sterben". ${ }^{205}$

However, Behrens' statement is more intertextually complex than Joseph's study indicates, since Nietzsche's fragment quoted above merely echoes Schopenhauer's belief that life is "ein fortdauernd gehemmtes Sterben". ${ }^{206}$ Furthermore, Behrens' relation of life to death also affirms the view of life and death as relative concepts expressed in the following aphorism from Nietzsche's Die fröhliche Wissenschaft: "Hüten wir uns zu sagen, dass Tod dem Leben entgegengesetzt sei. Das Lebende ist nur eine Art des Todten, und

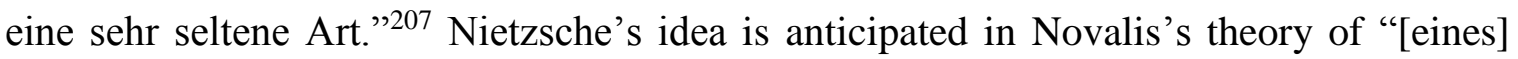
Leiter[s] des Lebens", ${ }^{208}$ according to which even inorganic material contains the essence of life ("Erregung"), ${ }^{209}$ simply below the level of human perception. ${ }^{210}$ Similarly,

\footnotetext{
${ }^{203}$ Nietzsche KSA 1, p. 139.

${ }^{204}$ Nietzsche KSA 4, p. 39.

${ }^{205}$ Nietzsche KSA 11, p. 577; also quoted in E. Joseph, op. cit., p. 116.

${ }^{206}$ Schopenhauer I, p. 427.

${ }^{207}$ Nietzsche KSA 3, p. 468.

${ }^{208}$ Novalis 2, p. 556. G. Brandes also refers to Novalis's view of life and death as relative concepts (G. Brandes, op. cit., p. 236).

${ }^{209}$ Novalis 2, p. 556.

${ }^{210}$ Thomas Mann refers to Novalis's perception of the "Organisch-Animalisch" on a molecular level in the speech "Von deutscher Republik" (Mann 15.1, p. 551).
} 
Schopenhauer believes that the Will to live is present even in inorganic matter, an idea he illustrates with the image of planets and "[deren] Streben vorwärts in den unendlichen Raum". ${ }^{211}$ Yet despite the intertextual link of Novalis's and Schopenhauer's texts to Behrens' statement quoted above, their supposition of a relationship between inorganic and organic material dialogically opposes the following passage in Der Zauberberg from the chapter section "Forschungen": "[Z]wischen Leben und unbelebter Natur [...] klaffte ein Abgrund, den die Forschung vergebens zu überbrücken strebte" (417). Instead, this passage corresponds referentially to the view espoused by both Schopenhauer and Nietzsche of life on earth as an arbitrary exception to the inorganic universe. ${ }^{212}$

The concept of death within life espoused by Settembrini and Director Behrens appears to dialogically oppose the Romantic view of death as rejuvenating, i.e. of life within death. The metaphorical equivalence of death and sleep in the German word "entschlafen" illustrates this Romantic idea, for example in Novalis's following note: "Schlaf analogon des Todes". ${ }^{213}$ Moreover, Novalis portrays death as rejuvenating in his fourth "Hymne an die Nacht" (“[i]ch fühle des Todes / Verjüngende Flut"). ${ }^{214}$ The entire constellation of sleep, death and rejuvenation is addressed by Schopenhauer in the following passage from Die Welt als Wille und Vorstellung: "Was für das Individuum der Schlaf, das ist für den Willen als Ding an sich der Tod [...]. [Der Wille] tritt durch diesen Todesschlaf erfrischt und mit einem andern Intellekt ausgestattet als ein neues Wesen wieder auf'. ${ }^{215}$ Ironic parallels to these texts can be found in Der Zauberberg in the chapter section "Fragwürdigstes", in which the spirit medium Elly Brand is placed by Dr Krokowski in a state of hypnotic sleep equated with death (1020). From this state, she "gives birth" (1026, 1029) to a vision of the deceased Joachim (1032). The fact that these scenes are portrayed negatively suggests that the primary text also rejects the Romantic view of death as rejuvenating; and indeed, this Romantic concept is clearly negated in the chapter section

\footnotetext{
${ }^{211}$ Schopenhauer I, p. 220.

212 Schopenhauer II, p. 382 (I owe the identification of this parallel to the work of S. Jordan, op. cit., p. 54); Nietzsche KSA 3, p. 468.

${ }^{213}$ Novalis 2, p. 622; see also Novalis 1, pp. 133-35.

${ }^{214}$ Novalis 1, p. 139.

${ }^{215}$ Schopenhauer II, p. 609.
} 
"Totentanz", in which Castorp's condolences while visiting the body of the Herrenreiter are contradicted by his perceptions: “'Er scheint zu schlafen', sagte er aus Menschlichkeit, obgleich große Unterschiede vorhanden waren." (444) This passage presents a conflict between the Romantic conception of death as revitalising and the biological finality of death, ${ }^{216}$ which in turn indicates a conflict between the Romantic view of death as rejuvenating and the atheist concept of death as final.

The conflict between atheist and Romantic concepts of death is clarified further in the novel as a clash between atheism and Christianity. Naphta's concept of death, for example, echoes the Romantic concept of death as rejuvenating by being transformational, the point at which "Erde und Himmel, Sinnliches und Übersinnliches sich berühren" (578). This link between Romanticism and Christianity is underscored by the interrelation of both in Novalis's portrayal of the soul's transcendence in death from his "Geistliche Lieder". 217 The Christian view of death as transformational is also explored in Der Zauberberg in the chapter section "Von der Taufschale und vom Großvater in zwiefacher Gestalt". Here, the young Castorp has the impression that his grandfather's portrait anticipates the elder Castorp's transformation in death, “[wenn seine] Interimsanpassung [...] feierlich überhoben [wird] und [er] in seine eigentliche und angemessene Gestalt endgültig ein[]kehrt" (45). Although this passage superficially suggests Schopenhauer's concept of death's dissolution of the individual Will into the primal Will, ${ }^{218}$ a closer examination reveals that the word "Gestalt" contradicts the Will's essential formlessness, and is in fact a textual signal that, coupled with the "form" of the grandfather in his portrait, indicates Novalis's following concept of the soul: "[D]enn ich nenne Seele [...] das individuelle Princip". ${ }^{219}$ Castorp's childhood impression consequently appears incompatible with

\footnotetext{
${ }^{216}$ Freud X, p. 348.

${ }^{217}$ Novalis 1, pp. 159-77.

218 Schopenhauer I, p. 392; see also Schopenhauer II, p. 637.

${ }^{219}$ Novalis 2, p. 551. According to Novalis, the human being is made up of body, soul and spirit. Whereas the spirit is metaphysical, the soul is part of the body: "Die Seele ist die Monas, deren Äußerungen mannichfaltige Monaden sind - der Sinn, sit Venia Verbis, der die übrigen Sinne durch Centralpuncte activirt und vereinigt. Der Geist dirigirt diesen monadischen Sinn - Activirt und punctirt beliebig die Urmonas." (ibid., p. 582)
} 
Schopenhauer's philosophy, in which the self is mortal, an aberration ("Irrtum") that death fortunately brings to an end. ${ }^{220}$

Paradoxically, considering the fundamentally oppositional nature of the atheist and Christian conceptions of death, Settembrini affirms the Romantic, Christian view of death as transformational by believing death to be part of a cycle of renewal: "Der Tod ist ehrwürdig als Wiege des Lebens, als Mutterschoß der Erneuerung” (304). This circular conception of death and life casts doubt on Settembrini's atheism when interpreted according to Freud's opinion that a belief in reincarnation undermines the (atheist) concept of death's finality. ${ }^{221}$ Yet Nietzsche claims the opposite, stating that linear time is dependent on the religious concept of eternity, now defunct after the demise of God;222 i.e. that circular time is a product of atheism. Indeed, Settembrini's convictions concur metatextually with the circular concepts of death and life proposed by Nietzsche and Schopenhauer (both atheists). In Die Welt als Wille und Vorstellung, for example, Schopenhauer describes death's release of the individual into the primal unity of the Will (“das Princip des Lebens"), ${ }^{223}$ from which a new individual is subsequently formed. Death is therefore merely a stage in the process of reincarnation. ${ }^{224}$ Similarly, Nietzsche proposes a concept of eternal recurrence, which he clarifies as follows in Ecce Homo: "Die Lehre von der 'ewigen Wiederkunft', das heisst vom unbedingten und unendlich wiederholten Kreislauf aller Dinge". 225 These texts are clearly related to the Christian concept of death as transformational, albeit assimilating the concept of the afterlife into life. The link between reincarnation and Christian dogma is also clear from the following passage from "Freiberger naturwissenschaftliche Studien" (1798/99), in which Novalis muses: "Sollte es

\footnotetext{
${ }^{220}$ Schopenhauer II, p. 628.

${ }^{221}$ Freud X, p. 348.

${ }^{222}$ L. Saariluoma. Nietzsche als Roman: Über die Sinnkonstituierung in Thomas Manns 'Doktor Faustus'. Tübingen: Max Niemeyer Verlag, 1996, p. 65. In further correspondence to Nietzsche's idea, Settembrini describes time in the chapter section "Vom Gottesstaat und von übler Erlösung" as "eine allgemein göttliche Einrichtung" (607).

${ }^{223}$ Schopenhauer II, p. 634.

${ }^{224}$ Ibid., pp. 642-47. Schopenhauer discusses reincarnation extensively in chapter 41 of the second volume of Die Welt als Wille und Vorstellung (ibid., pp. 589-651).

${ }^{225}$ Nietzsche KSA 6, p. 313.
} 
nicht auch drüben [im Himmel] einen Tod geben - dessen Resultat irrdische Geburt wäre."226

The chapter section "Schnee" in Der Zauberberg further blurs the distinction between Christianity and atheism by amalgamating the concepts of circular temporality, reincarnation and Christian transformation also present in the work of Novalis, Schopenhauer and Nietzsche. After losing his way in the snow and walking around in circles that are associated with both death and reincarnation by the pun inherent in the word "Umkommen" (735), Castorp has another circular experience - from life to death and back to life again. First, he loses consciousness (unconsciousness is a state approximate to death), and while unconscious he has a vision of perfection. Then, he has a vision of death that is so shocking he regains consciousness. ${ }^{227}$ A connection between this circular temporality and the Christian concept of transformation is made in the chapter section "Noch jemand". Here, in response to Settembrini's mention of "[des] unendlich gedachte[n] Fortschritt[s] der Menschheit" (577), Castorp objects that science has proven motion to be circular. However, Settembrini claims that his concept of progress follows the circular idea that mankind, although presently corrupt, was originally perfect and with effort can re-attain this perfection. Naphta then quickly points out that Rousseau (from whom this idea allegedly came) adopted this schema from Christian dogma, according to which the original innocence destroyed by Adam's sin can be reclaimed in death (578). ${ }^{228}$ This amalgamation of Christian metaphysics and Enlightenment social theory relates selectively to "Das allgemeine Brouillon", in which Novalis sets the perfection of heaven on earth by proposing "ein Princip der Vervollkommnung in der Menschheit"229 that promises an eventual return to the Golden Age: "Die Bibel fängt herrlich mit der Paradiese [...] an und schließt mit dem ewigen Reiche [Naphta's dogma] [...]. Jedes Menschen

\footnotetext{
${ }^{226}$ Novalis 3, p. 62; see also ibid., p. 663. Similarly, Novalis writes: "Alles Leben ist ein ununterbrochener Strom - Leben kommt nur von Leben" (Novalis 2, p. 575). In Heinrich von Ofterdingen, Mathilde shares the identity of die blaue Blume, of Edda, of "d[er] Morgenländerin" and of Cyane (Novalis 1, p. 368); Novalis subsequently ruminates in a fragment on "[dem]selbe[n] Individuum in Variationen" (Novalis 2, p. 562).

227 Time is portrayed in Der Zauberberg as circular on numerous occasions, for example when Castorp describes eternity as "nicht 'geradeaus, geradeaus', sondern 'Karussell, Karussell”' (560).

${ }^{228}$ Castorp's experience of losing his way in the snow can be seen as an ironic reference to the fall of man.

${ }^{229}$ Novalis 2, p. 291.
} 
Geschichte soll eine Bibel seyn [the social vision of Settembrini]". 230 With this text, Novalis once again blurs the distinction between Romantic Christianity and Classical atheism, thereby weakening the ideological opposition of Settembrini to Naphta. Furthermore, this blend of belief systems/philosophical systems highlights how even apparently opposing ideologies are actually part of the continuum of intellectual history.

\subsection{Attitudes towards death}

Atheist and Christian conceptions of death also inform attitudes towards dying in Der Zauberberg. In the chapter section "Ewigkeitssuppe und plötzliche Klarheit”, for example, Castorp reacts to his diagnosis with tuberculosis with a combination of fear and triumph:

Bald erschütterte, wie er so dalag, ein tolles, tief aufsteigendes Triumphgelächter von innen her seine Brust, und sein Herz stockte und schmerzte von einer nie gekannten, ausschweifenden Freude und Hoffnung; bald wieder erblaßte er vor Schrecken und Bangen, und es waren die Schläge des Gewissens selbst, mit denen sein Herz in raschem, fliegendem Takt gegen die Rippen pochte. (280) $)^{231}$

Castorp's mixed feelings towards his possible death reflect both the atheist view of death as the end of life and the Romantic (Christian) belief in an afterlife, and thus illustrate Castorp's position caught between the ideologies of Settembrini and Naphta. In addition, the description of Castorp's anxiety in terms of "Schläge des Gewissens" concurs highly referentially with Freud's conviction that the fear of death "[ist] meist aus Schuldbewußtsein hervorgegangen". 232

Yet challenging the view that atheism fosters a fear of death, Settembrini himself claims that death is "weder ein Schrecknis noch ein Mysterium, [...] [sondern] eine eindeutige, vernünftige, physiologisch notwendige und begrüßenswerte Erscheinung” (690). ${ }^{233}$ This bold statement relates metatextually to Nietzsche's following argument: "Ist

\footnotetext{
${ }^{230}$ Novalis 3, p. 321.

231 This ambivalent reaction is anticipated by Castorp's first fever of $37.6^{\circ}$ Celsius, when he alternately smiles to himself and takes deep, anxious breaths (260).

${ }^{232}$ Freud X, p. 351.

${ }^{233}$ See also 2.1, p. 26.
} 
der Tod nichts andres als bloße Abwesenheit des Lebens, so würden wir uns um ihn gar nicht zu kümmern haben; wie wir ja zu dem Nichtsein vor der Geburt stehen. Die Empfindungen des Lebens verbreiten einen Trug über das, was nicht mehr Leben ist.",234 Nietzsche's attitude is shared by Schopenhauer, who believes that the fear of death originates in the individual Will's mistaken belief that it is part of the world of representation and can therefore be destroyed. ${ }^{235}$ However, Schopenhauer's concept of the immortal Will resembles the Christian concept of the soul, albeit absorbed into nature, ${ }^{236}$ and his disdain for those who fear death can consequently be interpreted as a tacit criticism of atheism: "In der Tat sind es auch nur die kleinen, beschränkten Köpfe, welche ganz ernstlich den Tod als ihre Vernichtung fürchten."237 This criticism is applicable to Settembrini, whose confident claim quoted above is negated by his own fear of death (372, 583 ), in an example of authentic character inconsistency that sharply contrasts the "monologic utterance" of philosophy and its goal of a unity of thought. ${ }^{238}$

Intertextual analysis of the primary text reveals that Settembrini's fear is also the product of animal instinct. Nietzsche considers the fear of death to be natural, ${ }^{239}$ and Schopenhauer similarly declares: "Alles, was geboren wird, bringt sie [die Todesangst] schon mit auf die Welt". ${ }^{240}$ This animal fear is illustrated further in Der Zauberberg by the sanatorium patient Barbara Hujus, who reacts with abject terror at the arrival of a priest sent to administer her the last rites. Hujus screams at the sight of this priest, "ein Schreien ohne Pause und Ansatz, aus weit offenem Munde" (85). She then hides herself under the blanket: “[M]an sah nichts als eine formlose Masse darin, die bettelte und grauenhaft protestierte und mit den Beinen strampelte" (86). Hujus' flailing legs physically interpret the following passage from Schopenhauer's Die Welt als Wille und Vorstellung: “[Der

\footnotetext{
${ }^{234}$ Nietzsche KSA 8, p. 161.

235 Schopenhauer II, pp. 637-38; see also Schopenhauer I, p. 392.

${ }^{236}$ See 2.2, pp. 29-30.

237 Schopenhauer II, p. 607.

${ }^{238}$ M. M. Bakhtin. "Discourse in the Novel”, op. cit., pp. 270-71. This is particularly the case with Schopenhauer's philosophy, which is centred on the two concepts of "Wille" and "Vorstellung".

${ }^{239}$ Nietzsche KSA 1, p. 91.

${ }^{240}$ Schopenhauer II, p. 593.
} 
Wille] sträubt sich sein ganzes Wesen mit aller Gewalt [...] gegen [den Tod]". ${ }^{241}$ Physical resistance to death is also portrayed in the chapter section "Totentanz", in which the Herrenreiter endeavours to avoid death by climbing out of bed. After Director Behrens points out the futility of this action, the Herrenreiter lies down again and dies (442). However, this apparently easy capitulation is undermined by Castorp's later impression: "Die Augen [des Toten] waren auf eine gewisse unnatürlich feste Weise geschlossen, zugedrückt, mußte Hans Castorp denken, nicht zugemacht” (443).

Behrens' blunt treatment of the Herrenreiter is reflected in his directive to another terminally ill patient: "Stellen Sie sich gefälligst nicht so an!” (87) Similarly, Joachim considers it "eine unverzeihliche Schlappheit" (86-87) if a (male) patient makes a fuss about dying. Behrens' and Joachim's attitudes relate to a further passage from Die Welt als Wille und Vorstellung, in which Schopenhauer notes the superiority of composure in the face of death to resistance:

Wann [...] der Mensch dem Tode mutig und gelassen entgegengeht; so wird dies als groß und edel geehrt [...]. Imgleichen verachten wir den, [...] [der] dem Leben unbedingt anhängt, gegen den herannahenden Tod sich aufs äußerste sträubt und ihn verzweifelnd empfängt $[\ldots]^{242}$

Two characters in Der Zauberberg exhibit Schopenhauer's ideal resignation: Karen Karstedt and Joachim Ziemßen. In the chapter section "Totentanz", Castorp and Joachim accompany the terminally-ill Karen on a walk to the local cemetery. This poignant trip reaches a climax of intensity when the three friends inadvertently come to a halt before a space between the graves ("ein flaches Plätzchen von Menschenlänge, eben und unbelegt" [487]). Karen's resignation to her death is indicated by both her compliance with Castorp's suggestion that they visit the cemetery and her calm reaction to this space. She merely gazes at what might be her future grave, "und lächelt[] geziert mit gespitzten Lippen, wobei sie rasch mit den Augen blinzelt[]" (488).

\footnotetext{
${ }^{241}$ Ibid., p. 597; see also Schopenhauer I, p. 391.

${ }^{242}$ Schopenhauer II, p. 594.
} 
Joachim shows similar composure, approaching death "mit klarem Bewußtsein [und] in Harmonie und Zufriedenheit mit sich selber" (807). As well as to Schopenhauer's text quoted above, Joachim's attitude recalls Nietzsche's following description of the demise of Socrates in Die Geburt der Tragödie: "[M]it völliger Klarheit und ohne den natürlichen Schauder vor dem Tod [...] ging [er] in den Tod, mit jener Ruhe, mit der er nach Plato's Schilderung als der letzte der Zecher im frühen Tagesgrauen das Symposion verlässt, um einen neuen Tag zu beginnen". ${ }^{243}$ However, Nietzsche's text mocks Socrates for choosing death over prison in order to immortalise himself and his ideas. This negative evaluation of composure contrasts the sympathetic and poignant description of Joachim, and it seems that Joachim's attitude towards death borrows only the imagery of Nietzsche's text while communicating Schopenhauer's praise of composure. The affirmation of Schopenhauer's text in Der Zauberberg is underscored by the contrast between the serious and poignant portrayals of Karen and Joachim and the ironic pathos of the struggles of Barbara Hujus and the Herrenreiter. These variations in narrative tone shape the reader's response in complete accord with Schopenhauer's ideal.

The fear of death is violently negated by the suicides of Mynheer Peeperkorn and Leo Naphta in the chapter sections "Mynheer Peeperkorn (Schluß)" and "Die große Gereiztheit". Peeperkorn chooses death by poison (945), and Naphta shoots himself in the head after Settembrini sabotages a duel between them by discharging his pistol into the air (1069-70). The reasons for Peeperkorn's and Naphta's suicides are markedly different: Peeperkorn's decision to die follows his symbolic failure at life (his impotence), which is simultaneously a failure to fulfil "[seine] religiöse Funktion" (913). Peeperkorn's God is thus life itself, and his suicide can be interpreted as a form of self-damnation (if life is God/heaven, death must be hell). Naphta, on the other hand, believes in the Christian God and in the promise of an afterlife. His suicide is explained by Novalis's following claim that the fear of death is an illusion:

Die Selbstauflösung des Triebes - diese Selbstverbrennung der Illusion - des illusorischen Problems ist eben das Wollüstige der Befriedigung des Triebes. Was

\footnotetext{
${ }^{243}$ Nietzsche KSA 1, p. 91.
} 
ist das Leben anders. Die Verzweiflung, die Todesfurcht ist gerade eine der interessantesten Täuschungen dieser Art. ${ }^{244}$

Novalis's text explains Naphta's lack of fear as consequent to his belief in the immortal soul. The connection between fearlessness and a belief in immortality can also be found in texts by Schopenhauer and Freud, who both consider the latter to be innate to human beings. ${ }^{245}$ However, whereas Schopenhauer affirms this belief, Freud views it merely as a psychological mechanism.

Freud's psychological interpretation of fearlessness is explored further in the final pages of Der Zauberberg, which show Hans Castorp among three thousand soldiers on the front lines of World War I. According to the narrator, one third of these young men will die before they achieve the goal of recapturing a hill lost to the enemy two days previously, yet faced with the possibility of death, the soldiers' fear is outweighed by determination (1081-82). This subordination of terror is explained by Freud's "Massenpyschologie und Ich-Analyse" (1921), an essay that offers a psychological reinterpretation of Gustave Le Bon's Pyschologie der Massen (1895; first German edition 1908). In “Massenpyschologie und Ich-Analyse", Freud argues that a hypnotic state of fearlessness is produced in war by the bonds between soldiers and army superiors. ${ }^{246}$ Moreover, Freud's text explains Castorp's lack of compassion as he treads a fallen soldier's hand into the mud with his hobnailed boots on his way "hindurch" (1082-84). Interpreted according to Freud's work, both Castorp's lack of fear and his indifference towards others have been caused by his immersion in the human mass, which suppresses the intellect and consequently enables the primitive, egoistic drives to dominate. ${ }^{247}$

The lack of fear in the battle scene at the conclusion of Der Zauberberg also indicates the domination of death over life, according to the idea that fear is a lifepreserving response to danger. This idea is confirmed by the symbolism of mud in this

\footnotetext{
${ }^{244}$ Novalis 2, p. 562.

${ }^{245}$ Schopenhauer II, p. 622; Freud X, pp. 346, 351.

${ }^{246}$ Freud XIII, pp. 104-05. This state can dissolve into abject terror if the bonds between soldier and general are broken (ibid.).

${ }^{247}$ Ibid., pp. 79, 80.
} 
battle scene, which reflects the human mass of soldiers and is also used in Der Zauberberg to represent death. ${ }^{248}$ The following section will investigate death's dominance further in the context of atheism and Christianity, together with their influence on Hans Castorp.

\subsection{The affirmation of death and the devaluation of life}

The Christian concepts of an afterlife and of heaven lead to the celebration of death and to a subsequent devaluation of life. This is the view adopted from Medieval Catholic dogma by Novalis, ${ }^{249}$ who in the following fragments declares: "Annihilation des Jetzigen Apotheose der Zukunft, dieser eigentlichen bessern Welt, dies ist der Kern der Geheiße des Xstentums"; 250 "Leben ist der Anfang des Todes. Das Leben ist um des Todes willen". ${ }^{251}$ Novalis's Christian glorification of death is embodied in Der Zauberberg by Naphta, who is convinced that salvation is "transzendent" (578), i.e. possible only in heaven. A member of the Jesuit Order, Naphta converted to Christianity from Judaism in his youth. Analysis of Schopenhauer's Die Welt als Wille und Vorstellung reveals that this conversion was a deliberate choice to embrace death: Schopenhauer denounces Judaism's optimism as "ein[en] Grundirrtum der aller Wahrheit den Weg vertritt", ${ }^{252}$ while praising Christianity as “de[n] alten, wahren, und erhabenen Glauben der Menschheit". ${ }^{253}$ Naphta's particular selection of Catholicism also reflects Schopenhauer's views, following the latter's rejection of Protestantism as a waste product of Catholicism that fails to retain the Christian-ascetic ethic. $^{254}$ These excerpts from Die Welt als Wille und Vorstellung indicate an essential similarity between Catholicism and Schopenhauer's philosophy. ${ }^{255}$ Indeed, Schopenhauer

\footnotetext{
${ }^{248}$ Thus, in the chapter section "Nr. 34", Castorp imagines the Herrenreiter's decaying insides: "[A]lles ein Matsch und Schlamm..." (25)

${ }^{249}$ J. Neubauer. Bifocal vision: Novalis' philosophy of nature and disease. Chapel Hill: University of North Carolina Press, 1971, p. 60.

${ }^{250}$ Novalis 3, p. 469; also quoted (with slight variation) by Thomas Mann in "Von deutscher Republik" (Mann 15.1, p. 542).

${ }^{251}$ Novalis 2, p. 417.

${ }^{252}$ Schopenhauer II, p. 803.

${ }^{253}$ Ibid., p. 800.

${ }^{254}$ Ibid., p. 802.

${ }^{255}$ Ibid., p. 611.
} 
himself links his pessimistic world view to the Christian conception of the world as a "valle lacrimarum" (a vale of tears). ${ }^{256}$

Naphta is further associated in Der Zauberberg with the Middle Ages. The Jesuit Order, for example, was established in the $16^{\text {th }}$ century, ${ }^{257}$ Naphta's furniture is baroque (591-92), his Pietà is Gothic (592), and he is a Latin teacher by profession $(567,617)$. An explanation for the mediaeval motif can be found in the work of Nietzsche, who uses the figure of the ascetic priest to criticise the Christian ascetic ideal. ${ }^{258}$ This ascetic priest figure was arguably developed from Schopenhauer's following description of monasticism in Die Welt als Wille und Vorstellung: “[D]as Mönchstum [ist eine] methodische und, zu gegenseitiger Ermutigung gemeinsam betriebene Verneinung des Willens [zum Leben]". 259 Naphta's embodiment of the ascetic priest is compounded by his attempt to convince Castorp of his life-negating world view (see 593-611). This agenda corresponds referentially to Nietzsche's claim that the ascetic priest desires to dominate and manipulate his flock. ${ }^{260}$ Asceticism in Der Zauberberg peaks in Naphta's suicide, an act that selectively recalls Nietzsche's note in Jenseits von Gut und Böse of the ascetic's desire to be "Herr

256 Ibid., p. 806.

${ }^{257}$ R. Healy, op. cit., p. 176.

${ }^{258}$ Nietzsche KSA 6, p. 353; see also ibid., p. 359.

${ }^{259}$ Schopenhauer II, p. 802. When Castorp is diagnosed with tuberculosis, Settembrini remarks ironically: "Wie ein frommer Bruder. Man kann sagen, Ihr Noviziat ist beendet, Sie haben Profess getan. Meine feierliche Gratulation." (296) The reader's knowledge of Schopenhauer's and Nietzsche's texts discussed above leads to his or her interpretation of Castorp's initiation from visitor to patient as symbolic of his new affiliation with death.

${ }^{260}$ Mynheer Peeperkorn, Director Behrens, and Dr Krokowski are also ascetic priest figures who wield power over the patients at the sanatorium. Peeperkorn is a "Dirigent" (831) who conducts an orchestra of admiring patients; Director Behrens holds a position of medical authority, yet he fails to cure a single patient during Castorp's stay, and encourages both Castorp and Joachim to remain at the sanatorium. Behrens' role as an ascetic priest is humorously illustrated in the chapter section "Fülle des Wohllauts". Here, the patients "b[e]ten flehentlich" (966) that Behrens play them music on the gramophone. Dr Krokowski's identity as an ascetic priest is clear from his uniform, which resembles a monk's habit (73), complete with woollen socks and sandals (194), and from his posture while lecturing, which is reminiscent of Jesus on the cross (198). Furthermore, the narrator describes Krokowski "preaching" with a biblical reference to Jeremia 6, 16: "Kommet her zu mir, sagte er [Krokowski] mit anderen Worten, die ihr mühselig und beladen seid!" (198) Erkme Joseph also discusses the presence of the ascetic priest figure in Der Zauberberg (E. Joseph, op. cit., pp. 66, 101-03, 162, 170). 
[...] über das Leben selbst". ${ }^{261}$ The reader's knowledge of this text leads him or her to conclude that Naphta aims to conquer life by destroying his own.

Naphta's ascetic devaluation of life is challenged in Der Zauberberg by Settembrini, who warns Castorp that the separation of death from life makes death "zur eigenen, dem Leben entgegengesetzten Macht, zum widersacherischen Prinzip" (620). This warning reiterates an earlier argument of Settembrini's from the chapter section "Ewigkeitssuppe und plötzliche Klarheit":

Der Tod ist ehrwürdig als Wiege des Lebens, als Mutterschoß der Erneuerung. Vom Leben getrennt gesehen, wird er zum Gespenst, zur Fratze - und zu etwas noch Schlimmerem. Denn der Tod als selbständige geistige Macht ist eine höchst liederliche Macht, deren lasterhafte Anziehungskraft zweifellos sehr stark ist, aber mit der zu sympathisieren ebenso unzweifelhaft die greulichste Verirrung des Menschengeistes bedeutet. (304-05) 262

Settembrini's fear that the religious isolation of death will damage Castorp's relationship to life (301-02) is confirmed by Castorp himself, who claims: "Wir haben ein Lied in unserem Volksliederbuch, worin es heißt: 'Ich bin der Welt abhanden gekommen'. So steht es mit mir." (898-99 $)^{263}$ Here, Castorp refers to a musical arrangement of Friedrich Rückert's poem by Gustav Mahler. Intertexts by Freud and Nietzsche suggest that the intense dissatisfaction with life expressed in this Lied is linked to Christianity. In the essay "Zeitgemäßes über Krieg und Tod", for example, Freud argues that the religious emphasis on the afterlife has dangerous consequences for life: "[D]ie Religionen [brachten es] zustande, diese Nachexistenz für die wertvollere, vollgültige auszugeben und das durch den Tod abgeschlossene Leben zu einer bloßen Vorbereitung herabzudrücken". ${ }^{264}$ In Der Antichrist (1889), Nietzsche similarly links religion to the devaluation of life: "Wenn man das Schwergewicht des Lebens nicht in's Leben, sondern in's 'Jenseits' verlegt - in's

\footnotetext{
${ }^{261}$ Nietzsche KSA 5, p. 363.

${ }^{262}$ Thomas Mann expresses this idea in the speech "Von deutscher Republik": "Und ist [es] nicht lasterhafte Romantik [...], wenn der Tod als selbständige geistige Macht dem Leben entgegengestellt wird, statt heiligend-geheiligt darin aufgenommen zu werden" (Mann 15.1, pp. 557-58).

${ }^{263}$ The world's symbolic representation of life is clear from the second stanza of this song: "Denn wirklich bin ich gestorben der Welt".

${ }^{264}$ Freud X, p. 348.
} 
Nichts -, so hat man dem Leben überhaupt das Schwergewicht genommen." ${ }^{265}$ Nietzsche consequently refers to Christianity as "[eine] Religion gewordne Verneinung des Willens zum Leben", ${ }^{266}$ and to God as "[den] Gegensatz-Begriff zum Leben". ${ }^{267}$ These texts by Freud and Nietzsche also suggest that Settembrini's attack of death-affirmation is really an attack of the asceticism within Christianity.

Although Castorp only confesses in chapter seven that he has become lost to the world (see above), his affirmation of death is evident throughout the novel. This "Sympathie mit dem Tode"268 can be seen in Castorp's reception of Settembrini's and Naphta's ideas, for example in his genuine enthusiasm at meeting Naphta: "So ein Umgang [mit Naphta] erweitert ja den Horizont in ganz unverhofftem Grade und gibt Einblick in eine Welt, von deren Existenz man keine blasse Ahnung hatte. Ein richtiger Jesuit!” (618) In contrast, Castorp's polite agreement with Settembrini's affirmation of life in the chapter sections "Ewigkeitssuppe und plötzliche Klarheit" and "Noch jemand" is only superficial (293-307, 584), and when Castorp jokes that he would be tempted to cheat when recording his daily temperature if it meant having the pleasure of Settembrini's company for longer (306-07), this joke contains a nugget of truth that affirms death: in the chapter section "Das Thermometer", Castorp's desire to be ill leads him to misinterpret the mercury level in his thermometer (261). Furthermore, while listening to one of Settembrini's pedagogic monologues, Castorp fixes absentmindedly on the latter's use of the word "Heimat" to describe the sanatorium (302-03; see also 135). Castorp's dreamy repetition of this word is devoid of Settembrini's original irony, and shows his attraction to the concept of death as a "homeland". This passage thus selectively recalls Novalis's following metaphoric equation of heaven and home: "Wo gehn wir den hin? Immer nach Hause", ${ }^{269}$

\footnotetext{
265 Nietzsche KSA 6, p. 217.

${ }^{266}$ Nietzsche KSA 6, p. 359. The Christian afterlife is consequently “ein Jenseits, erfunden, um das Diesseits besser zu verleumden, im Grunde ein Verlangen ins Nichts, ans Ende, ins Ausruhen” (Nietzsche KSA 1, p. 18).

${ }^{267}$ Nietzsche KSA 6, p. 373. In Die Geburt der Tragödie, Nietzsche opposes Jesus with the life-affirming Dionysus ("de[r] Antichrist”) (Nietzsche KSA 1, p. 19).

268 Thomas Mann uses the term "Sympathie mit dem Tode" in Betrachtungen eines Unpolitischen (Mann 13.1, p. 44), and mentions Castorp's own sympathy with death in a letter to Paul Amman of 25 March 1917 (Mann 22, p. 180).

${ }^{269}$ Novalis 1, p. 325.
} 
Castorp's positive attitude towards death can be traced to "eine[r] Grundstimmung des Gemütes" (304) established in his childhood. ${ }^{270}$ In the chapter section "Ewigkeitssuppe und plötzliche Klarheit”, for example, Castorp confesses:

Ein gewisser Ernst und eine gewisse Abneigung gegen robustes und lautes Wesen lag immer in meiner Natur, - wir sprachen noch neulich davon, und daß ich manchmal fast Lust gehabt hätte, geistlich zu werden, aus Interesse für traurige und erbauliche Dinge, - so ein schwarzes Tuch, weißt du, mit einem silbernen Kreuz darauf oder R.I.P. ... Requiescat in pace ... das ist eigentlich das schönste Wort und mir viel sympatischer als 'Hoch soll er leben' [...]. (282-83)

Castorp's tendency to affirm death is also revealed when he leans his head on one side while listening to Settembrini and Naphta discuss war (i.e. death) in the chapter section "Noch jemand" (576). The motivic connection of this posture to death is apparent from its many repetitions in the novel (see $38,333,443,487,576,593)$. In the chapter section "Von der Taufschale und vom Großvater in zwiefacher Gestalt”, for example, Castorp listens "seitwärts geneigten Kopfes" (38) while his grandfather reads out the names on the family baptismal bowl, an intonation of "Ur-Ur-Ur-Ur" (38) symbolic of death:

[Der junge Castorp] meinte modrig-kühle Luft, die Luft der Katharinenkirche oder der Michaeliskrypte zu atmen bei diesem Laut, den Anhauch von Orten zu spüren, an denen man, den Hut in der Hand, in eine gewisse, ehrerbietig vorwärts wiegende Gangart ohne Benutzung der Stiefelabsätze verfällt; abgeschiedene, gefriedete Stille solcher hallender Orte glaubte er zu hören [...]. (39) ${ }^{271}$

The references to religion in the two passages quoted above stress the Christian fundament to Castorp's sympathy with death. Furthermore, the link of Castorp's character and family history to Christian pessimism gives a sociological slant to Settembrini's earlier warning about the Romantic, Christian view of death, and suggests that the text of Der Zauberberg questions the loyalty of $20^{\text {th }}$-century German society to its Romantic, Christian past.

\footnotetext{
270 This reflects Thomas Mann's own reception of Schopenhauerian pessimism in his youth (Mann 13.1, p. 87 ; see also 1.1, p. 3 [footnote 48]).

271 The motif of tiptoeing in this passage is associated in Der Zauberberg with death (see 443, 457, 469), as is the posture of leaning forward slightly and the act of taking off one's hat (85).
} 
Castorp's glorification of death leads him to defy the secrecy at the sanatorium by paying visits to terminally-ill patients confined to their rooms. These visits appear serendipitous; however, their descriptions as educative "Unternehmungen" (460, 483) reveal that Castorp is actually motivated by personal curiosity. Castorp's interest in the dying conforms to the Christian conception of death as mysterious and venerable. ${ }^{272}$ Accordingly, he sends each patient flowers (the dying are like birthday boys and girls [460]), he tiptoes in their presence $(457,469)$, and his voice when speaking to them is “gedämpft und bewegt, mit zärtlicher Ehrerbietung" (457). Yet Castorp's conception of death as worthy and serious is challenged by the failure of these terminally-ill patients to take death seriously. The Mexican Lauro declares his intention to die a hero, whereupon "er [...] sich das Hemd auf[riß], um den Streichen des Todes die gelbe Brust zu bieten" (469). Frau Zimmermann's lips are blue from lack of oxygen, yet she finds her predicament hilarious and laughs throughout Castorp's visit (463-66). The businessman Fritz Rotbein is in the process of weighing up whether a life-prolonging operation would be worth the money (461). Leila Gerngroß, Lady von Mallinckrodt and the 16-year-old boy Teddy appear indifferent to their terminally ill state. ${ }^{273}$ Leila is delighted to have visitors, Lady von Mallinckrodt flirts coquettishly with Castorp (473-75), and Teddy makes it clear, "daß er vom Leben nichts anderes mehr, als eben immer nur dies, erwarte" (473). Castorp is taken aback by the attitudes of these patients towards death: he is annoyed by Frau Gerngroß's mistaken delight that he has come to flirt with her dying daughter $(459,468)$, and disapproves both of Frau Zimmermann's incessant giggling $(466,468)$ and of Herr Rotbein's calculating attitude (468). Castorp's subsequent decision to take the terminallyill Karen Karstedt on a walk to the local cemetery ${ }^{274}$ reflects his conviction that a stroll among the graves is "moralisch passend[]" (485), and is an attempt to impose his own affirmation of death on others.

Castorp's sympathy with death is also clear in the chapter section "Neckerei, Viatikum. Unterbrochene Heiterkeit", in which he protests against Behrens' rough

\footnotetext{
${ }^{272}$ See 2.1, p. 26.

${ }^{273}$ However, a certain reluctance to die is inferred by Leila's surname "Gerngroß", which translates as a "wish to be grown-up".

${ }^{274}$ See 2.3 , p. 38.
} 
treatment of the terminally ill: "[E]in Sterbender ist [...] sozusagen heilig, sollte ich meinen!" $(87)^{275}$ This respectful attitude towards the dying illustrates the Christian "Reverenz vor dem Elend" (678) that is adopted by Schopenhauer in the following excerpt from Die Welt als Wille und Vorstellung: "[J]eder Todesfall stellt sich gewissermaßen als eine Art Apotheose oder Heiligsprechung dar; daher wir den Leichnam auch des unbedeutendesten Menschen nicht ohne Ehrfurcht betrachten". ${ }^{276}$ Yet Castorp's reverence for suffering is parodied in the chapter section "Vom Gottesstaat und von übler Erlösung", in which Naphta claims to find the late $12^{\text {th }}$ century tract De miseria humanae conditionis “aüßerst witzig[]" (594). This delight in suffering is also evident from Naphta's Gothic Pietà:

[D]ie Gottesmutter in der Haube, mit zusammengezogenen Brauen und jammernd schief geöffnetem Munde, den Schmerzensmann auf ihrem Schoß, eine im Größenverhältnis primitiv verfehlte Figur mit kraß herausgearbeiteter Anatomie, die jedoch von Unwissenheit zeugte, das hängende Haupt von Dornen starrend, Gesicht und Glieder mit Blut befleckt und berieselt, dicke Trauben geronnenen Blutes an der Seitenwunde und den Nägelmalen der Hände und Füße. (592)

The Pietà's celebration of pain metatextually parallels Schopenhauer's praise of suffering in Die Welt als Wille und Vorstellung. Here, Schopenhauer concludes that pain is not only “das Panakeion [Allheilmittel] unsers Jammers", ${ }^{277}$ but also life's "reinigende Lauge". 278

The Christian/Schopenhauerian affirmation of pain is rejected by Settembrini, who deliberately seats himself with his back turned to Naphta's Pietà (596). Moreover, Settembrini counteracts Schopenhauer's praise of the choice to embrace suffering as holy ${ }^{279}$ by using religious metaphor in a mocking way to describe the masochism of Anton Ferge (“"nachgerade trage er [seinen Leiden] wie einen Heiligenschein um den Kopf” [680]). ${ }^{280}$

\footnotetext{
275 This idea is reiterated in the chapter section "Totentanz": "[E]inem Sterbenden gebühre jeder Respekt und Ehrenaufwand, darauf besteht Hans Castorp" (442).

276 Schopenhauer II, p. 817.

277 Ibid., p. 820.

278 Ibid., p. 821.

${ }^{279}$ Ibid., p. 819.

${ }^{280}$ Masochism will be discussed in more detail in subchapter 5.4 (see pp. 170-78).
} 
Settembrini's opposition to the ascetic affirmation of pain is reflected in his life's work, a contribution to an encyclopaedia (Soziologie der Leiden) that aims, "das menschliche Leiden durch zweckvolle soziale Arbeit zu bekämpfen und am Ende völlig auszumerzen" (373). This rejection of suffering dialogically opposes Nietzsche's concept of amor fati: "[E]in Jasagen ohne Vorbehalt, zum Leiden selbst, zur Schuld selbst, zu allem Fragwürdigen und Fremden des Daseins selbst". ${ }^{281}$ Yet Nietzsche's acceptance of life in its totality also contrasts the negation of life inherent in Naphta's glorification of suffering. The intertextual role of Nietzsche's concept of amor fati is revealed by the tone of the primary text: while Settembrini's complete confidence that human suffering can be eradicated appears ridiculous, Naphta's gruesome Pietà is repugnant. The position of Nietzsche's text between these critical portrayals tacitly affirms amor fati as an ideal alternative.

The criticism of asceticism continues in Der Zauberberg in the depiction of ascetic violence. This is championed by Naphta, who declares in the chapter section "Vom Gottesstaat und von übler Erlösung": "Gotteseifer kann selbstverständlich nicht pazifistisch sein" (606). Naphta consequently applauds the mediaeval ascetic monks who killed in the name of God (676; see also 570), and praises the Spanish Inquisition for purifying the world "von schlechten Bürgern" (598). For Naphta, religious violence serves a political agenda, and he predicts a communist uprising that will use "Terror[]" (607) to enforce principles of asceticism and domination "im Zeichen des Kreuzes" (609). Naphta's role as an ascetic priest prepared to lead his disciples to war/death in the name of God links him metatextually to the essay "Massenpyschologie und Ich-Analyse", in which Freud describes the control of "künstliche[r] Massen" by the powerful father-figures of Christ and the army General. ${ }^{282}$

Although Naphta's anarchic communism promises to destroy social hierarchies (604), his goal of "eine[r] Diktatur des Proletariats" (608) reconciles communism with structures of power. This reflects his Christian belief in a hierarchy of church and state (605; see also 597), a "weltüberwindende[r] Kosmopolitismus der Kirche" (579) that corresponds metatextually to Novalis's following hierarchy of heaven and world: "Die

\footnotetext{
${ }^{281}$ Nietzsche KSA 6, p. 311; see also ibid., pp. 297, 363; Nietzsche KSA 1, p. 12.

${ }^{282}$ Freud XIII, p. 102. See also 2.3, p. 40.
} 
Menschheit ist gleichsam der höhere Sinn unsers Planeten - das Auge, was er gen Himmel hebt - der Nerv, der dieses Glied mit der obern Welt verknüpft." ${ }^{283}$ Novalis's text reveals the affirmation of death in Naphta's political ideal by emphasising the superiority of God (death) over the world. Furthermore, the criticism of Naphta's asceticism in Der Zauberberg is linked to contemporary politics via his ideal of communism, which at the end of the $19^{\text {th }}$ century was commonly regarded as a threat to culture. ${ }^{284}$ The interrelation of Naphta's communist and religious ideals implies that Romantic, Christian deathaffirmation has similarly negative social implications.

\subsection{The glorification of death as release}

Naphta's blend of Romanticism, Christianity and communism discussed in the previous subchapter is opposed by Settembrini, who defends democracy and the freedom of the individual $(566,610)$. These values are joined by an affirmation of action, and Settembrini introduces Castorp and Joachim to Naphta in the chapter section "Noch jemand" by stating their professions, and by ascribing to both an eagerness to return to the world of work (567). ${ }^{285}$ An association of this activity with Settembrini's affirmation of life is enabled by the reader's knowledge of Ecce Homo, in which Nietzsche presents the Kunsttrieb (artistic instinct) Dionysus not only as "höchste That" 286 and as "Werden", ${ }^{287}$ but also as "das Jasagen zum Leben [...]; der Wille zum Leben". ${ }^{288}$ In contrast to Settembrini's affirmation

\footnotetext{
${ }^{283}$ Novalis 2, p. 562. Thomas Mann quotes this passage in "Von deutscher Republik" (Mann 15.1, p. 548).

${ }^{284}$ P. R. Hofstätter. “Einführung”, in G. Le Bon's Psychologie der Massen. Stuttgart: Kröner Verlag, 1982, p. XXI. Thus, religious hierarchy is related in Der Zauberberg to social hierarchy. Castorp's conservative grandfather is "auf aristokratische Einengung des gesellschaftlichen Kreises [...] hartnäckig bedacht" (41), an elitism reminiscent of Nietzsche's "vornehmer Mensch" in Jenseits von Gut und Böse, an ideal figure that combines an "Instinkt für den Rang" with an "Instinkt der Ehrfurcht" (Nietzsche KSA 5, p. 217). The grandfather's conservatism in Der Zauberberg also recalls Novalis's description of the king as an "erhobener Mensch" (Novalis 2, p. 489) comparable to "d[er] Sonne im Planetensystem" (ibid., p. 488). This fragment clearly relates social hierarchy to the cosmic hierarchy of God and world.

${ }^{285}$ In Betrachtungen eines Unpolitischen, Thomas Mann similarly claims: [D]ie Arbeit ist ein ethisches Lebenssymbol" (Mann 13.1, p. 116).

${ }^{286}$ Nietzsche KSA 6, p. 343.

${ }^{287}$ Ibid., p. 313. Dionysus consequently resembles the "Übermensch" in Nietzsche's Also sprach Zarathustra: "[D]ie seiende Seele, welche ins Werden, die habende, welche ins Wollen und Verlangen will -" (ibid., p. $344)$.

${ }^{288}$ Ibid., p. 312.
} 
of life and action, Naphta considers work to be of no value (608); instead, sloth is God's will, "da tätig sein zu wollen Gott beleidigen heiße, der allein handeln wolle" (569). However, when Settembrini contrasts Europe, characterised by "d[er] Tat und de[m] Fortschritt" (569), with the inactivity of the East (568), ${ }^{289}$ Naphta objects that the religious negation of action has an occidental heritage in Quietism (569). This claim relates to Novalis's belief that, for the intelligent person, the external world as well as his or her feelings "wird absolut, zum Fato". ${ }^{290}$ Naphta's viewpoint also recalls Schopenhauer's praise of Quietism as instrumental to the negation of the Will. ${ }^{291}$ These texts by Novalis and Schopenhauer underscore the glorification of death inherent in Naphta's ideas and lead to the reader's interpretation of Naphta's beloved "Ruhebett" (568) as synonymous with the grave.

Naphta mocks Settembrini's world of activity by calling it “[d]ie Mühle” (568), a highly communicative, selective word that reflects the following passage from Novalis's essay "Die Christenheit oder Europa” (1799):

[D]er Religions-Haß [...] machte die unendliche schöpferische Musik des Weltalls zum einförmigen Klappern einer ungeheuren Mühle, die vom Strom des Zufalls getrieben und auf ihm schwimmend, eine Mühle an sich, ohne Baumeister und Müller und eigentlich ein ächtes Perpetuum mobile, eine sich selbst mahlende Mühle sey. ${ }^{292}$

Naphta's allusion to this parody of the Enlightenment, mechanistic conception of the world clearly indicates a Romantic, Christian antipathy towards Settembrini's atheism; and indeed, Naphta's subsequent praise of inactivity (568) is revealed as inherently Romantic

\footnotetext{
${ }^{289}$ Novalis's Heinrich von Ofterdingen also contains an opposition of East and West (G. Brandes, op. cit., p. 280). Børge Kristiansen explores the thematic connections of East and West to the concept of death as "Unform" and "Überform" in Der Zauberberg (B. Kristiansen. Thomas Manns Zauberberg und Schopenhauers Metaphysik, op. cit.).

${ }^{290}$ Novalis 2, p. 607; see also ibid., pp. 597, 609. Georg Brandes also discusses Novalis's Quietism (G. Brandes, op. cit., p. 244).

${ }^{291}$ Schopenhauer I, p. 393; Schopenhauer II, pp. 780-785. Nietzsche's concept of amor fati discussed in 2.4 (see p. 48) can be seen as a life-affirming variation of Quietism.

${ }^{292}$ Novalis 3, p. 515; also quoted in G. Brandes, op. cit., pp. 247-48.
} 
by its association with Novalis's character Heinrich von Ofterdingen, whom Georg Brandes believes embodies Romantic "Sehnsucht [als] Unthätigkeit". 293

Naphta's affirmation of inactivity is reflected ironically in Hans Castorp's reluctance to work (92) and in his alleged unsuitability for action ("[r]echt gesund fühle ich mich eigentlich nur, wenn ich gar nichts tue -" [94]). Although Castorp agrees politely with Settembrini's positive description of northern Germans as "phlegmatisch und energisch" (300), his subsequent comments on his hometown and social milieu in the chapter section "Ewigkeitssuppe und plötzliche Klarheit" reveal a negative attitude towards activity:

Wer nicht die besten, teuersten Weine servieren läßt bei seinen Diners, zu dem geht man überhaupt nicht, und seine Töchter bleiben sitzen. So sind die Leute. Wie ich hier so liege und es von weitem sehe, kommt es mir kraß vor. Was brauchten Sie [Settembrini] für Ausdrücke, - phlegmatisch und? Und energisch! Gut, aber was heißt das? Das heißt hart, kalt. Und was heißt hart und kalt? Das heißt grausam. Es ist eine grausame Luft da unten, unerbittlich. Wenn man so liegt und es von weitem sieht, kann es einem davor grauen. (301)

This cruel world of activity contrasts the pleasant, passive existence at the sanatorium, ${ }^{294}$ and Castorp's clear preference for the latter confirms his sympathy with death.

Settembrini groups the principle of activity inherent to life together with the Enlightenment values of form (596) and individualism $(569,602)$. These values correspond to the principles embodied by Apollo, the second of Nietzsche's artistic drives. ${ }^{295}$ Apollonian form is also illustrated in Der Zauberberg in the chapter section "Forschungen", in which organisation is similarly presented as inherent to life (428-29). A further connection between organisation and culture is made in the chapter section "Schnee", when, after losing his way in the snow, ${ }^{296}$ Castorp has a vision of a group of people

${ }^{293}$ G. Brandes, op. cit., p. 303; see also ibid., pp. 265-303. Settembrini also associates action with the Enlightenment and inaction with the Middle Ages, describing Naphta's stance as "das Faulbett des Mönches" (569).

294 The passivity of life at the sanatorium is illustrated by the frequency of the meals (five per day), which indicates that the patients eat whether they are hungry or not.

${ }^{295}$ Nietzsche KSA 1, pp. 31, 39-40.

296 See 2.2, p. 35 . 
("Sonnenleute" [742]) whose behaviour is strikingly formal and stylised (740-43). This scene and its portrayal of social harmony parallels Novalis's belief that society, like life, is based on organisation. ${ }^{297}$

The harmony exhibited by the "Sonnenleute" is contrasted in the second half of Castorp's snow dream by his sight of two hags tearing apart a child (745). The subsequent association of death with the dissolution of form is reflected in the amorphism (596), denial of the self and of the personality, and obedience (603) characteristic of Naphta's communism. ${ }^{298}$ These passages recall Apollo's counterpart, Dionysus, who embodies the principle of dissolution. ${ }^{299}$ Yet Dionysus not only is a principle of destruction but also represents the chaos of life. Thus, while the hags' dismemberment of the child in Castorp's snow vision clearly corresponds to Nietzsche's description of Dionysus's death by "Zerstückelung", 300 their consumption of the child's flesh concurs with the Dionysian principle of renewal. The further association of the witches' feast ("Blutmahl” [746, 747]) with the symbolic, sacramental consumption of Christ's body ("Abendmahl") indicates that this concept of renewal is compatible with death, an idea that relates to Novalis's inversion of the sacrament, in which the soul dissolves "in das Innre des verbrausenden Leibes [Gottes]". ${ }^{301}$ In the first of his "Hymnen an die Nacht", Novalis similarly appeals to God: "[Z]ehre mit Geisterglut meinen Leib, daß ich luftig mit dir inniger mich mische". ${ }^{302}$ The juxtaposition of the intertextual correspondences within Der Zauberberg discussed above reveals interesting similarities between Nietzsche's concept of Dionysus and Romanticism.

Both the Dionysian principles of life chaos and dissolution are opposed in Der Zauberberg by the positive concept of life as "Haltung" (a life stance). Joachim, for example, resists the affirmation of death at the sanatorium, distrusts Naphta (582), and

\footnotetext{
${ }^{297}$ Novalis 2, p. 437. In addition, the beautiful natural surroundings in Castorp's vision are reminiscent of a scene from Novalis's Die Lehrlinge zu Sais (Novalis 1, p. 96).

298 Similarly, although Naphta is an intellectual who presents his arguments rationally, his arguments themselves express the chaos of death. As Settembrini declares: "Seine [Naphtas] Form ist Logik, aber sein Wesen ist Verwirrung." (614)

${ }^{299}$ Nietzsche KSA 1, pp. 72, 103.

${ }^{300}$ Ibid., p. 72.

${ }^{301}$ Novalis 3, p. 520.

${ }^{302}$ Novalis 1, p. 133; see also ibid., p. 136.
} 
desires to resume his martial duties in Germany (630-32). Joachim's stance expresses tension in selective correspondence to Novalis's description of the biological organism as "gespannt[]",303 and of life as "Krampf [sic]"304 and "eine erzwungne Oxydation".305 Similarly, Freud views life as "Spannung"306, and Schopenhauer notes the following: "[D]ie Unterhaltung des Lebensprozesses [...] [geht] nicht ohne Widerstand, folglich nicht ohne Anstrengung vor sich". ${ }^{307}$ This tension inherent to life culminates in Der Zauberberg in the strenuous effort of dying. Although the narrator poses the question in the chapter section "Von der Taufschale und vom Großvater in zwiefacher Gestalt" whether Castorp's dead grandfather is "siegreich oder überwunden" (44), the elaborate presentation of the body surrounded by flowers (46) clearly celebrates accomplishment. This concept of dying as an achievement relates metatextually to Freud's following observation in "Zeitgemäßes über Krieg und Tod": "Dem Verstorbenen [...] bringen wir ein besonderes Verhalten entgegen, fast wie eine Bewunderung für einen, der etwas sehr Schwieriges zustande gebracht hat." 308

The struggle of dying is resolved at the moment of death. This release of tension is illustrated by Joachim's passing in the chapter section "Als Soldat und brav":

Sein [Joachims] Auge brach, die unbewußte Anstrengung seiner Züge wich, die Mühsalsschwellung der Lippen schwand zusehends dahin, Verschönung zu frühmännlicher Jugendlichkeit breitete sich über unseres Joachims verstummtes Antlitz, und so war's geschehen. (811)

The message of this passage recalls the concept of death as release in the work of Novalis and Schopenhauer. In the first part of Heinrich von Ofterdingen (1802), for example, the

\footnotetext{
${ }^{303}$ Novalis 2, p. 553.

304 Ibid.

${ }^{305}$ Novalis 3, p. 687. Further connections to this fragment by Novalis can be found in Der Zauberberg in Director Behrens' claim that life is "Oxydation. [...] Sauerstoffbrand des Zelleneiweiß” (404). In addition, Thomas Mann quotes this fragment in both "Die Stellung Freuds in der modernen Geistesgeschichte" (P. Mendelssohn (ed.). Thomas Mann. Gesammelte Werke in Einzelbänden. Leiden und Größe der Meister, op. cit., p. 901) and "Von deutscher Republik" (Mann 15.1, p. 558).

${ }^{306}$ Freud XIII, pp. 40, 60, 69.

307 Schopenhauer II, p. 599.

${ }^{308}$ Freud X, p. 342.
} 
character Fabel sings: “In Lieb' und Frieden endigt sich der Streit [des Lebens], / Vorüber ging der lange Traum der Schmerzen". ${ }^{309}$ Similarly, Schopenhauer ruminates in Die Welt als Wille und Vorstellung: "[D]as gänzliche Aufhören des Lebensprozesses [...] [muß] eine wundersame Erleichterung sein [...]: vielleicht hat diese Anteil an dem Ausdruck süßer Zufriedenheit auf dem Gesichte der meisten Toten". ${ }^{310}$ These metatexts suggest that the release inherent to Joachim's death is positive.

With his passing, Joachim's life stance is destroyed, and his body soon begins "sich innerlich von der Form zu trennen und zu lösen" (814). This biological dissolution is explained in the chapter section "Humaniora" by Director Behrens, who observes that organic compounds "werden durch die Fäulnis in simplere Verbindungen zerlegt, in anorganische" (403). Behrens' statement, considered in conjunction with a passage from "Forschungen" that declares the impossibility of "elementare[n] Leben[s]" (429), corresponds selectively to Novalis's following claim: “[Der] Todt ist das Einfache, das Element". 311 The intertextual correspondence between Novalis's work and "Humaniora" continues when Behrens explains decay in terms of liquid: "Man fließt auseinander, sozusagen. Bedenken Sie all das Wasser!" (403) This statement relates selectively to Novalis's concept of "d[es] Urflüssige[en]"312 symbolic of eternity and reminiscent of Schopenhauer's Will.

The concept of death as release is also expressed in Der Zauberberg through music. In the chapter section "Fülle des Wohllauts", the arrival of a new gramophone is embraced by the sanatorium patients with enthusiasm. This gramophone is described as a coffin from within which the voice (soul) of a singer can be heard (974). ${ }^{313}$ The connection between music and death is anticipated by Settembrini, who warns in the chapter section "Politisch

\footnotetext{
${ }^{309}$ Novalis 1, p. 315.

310 Schopenhauer II, p. 599. This follows Schopenhauer's belief that death is “die schmerzliche Lösung des Knotens [vom Leben]" (ibid., pp. 648-49).

${ }^{311}$ Novalis 3, p. 60; see also K. Hamburger, op. cit., p. 57.

312 Novalis 1, p. 104; see also K. Hamburger, op. cit., p. 62.

313 The coffin motif is introduced in the chapter section "Er versucht sich in französischer Konversation". Here, Castorp enthuses to Joachim: "Siehst du nicht ganz gern einen Sarg? Ich sehe ganz gern mal einen. Ich finde, ein Sarg ist ein geradezu schönes Möbel, schon wenn er leer ist, aber wenn jemand darin liegt, dann ist es direkt feierlich in meinen Augen." (168)
} 
verdächtig!" that, uncoupled from literature, "Musik allein ist gefährlich" (174). Settembrini's implied preference for text recalls Die Geburt der Tragödie, in which Nietzsche claims that a domination of text over music is typical of the Alexandrian optimism that has produced the modern "theoretischer Mensch". ${ }^{114}$ Nietzsche's text establishes Settembrini's resemblance to the "Zivilisationsliterat" attacked by Thomas Mann in the Betrachtungen eines Unpolitischen, ${ }^{315}$ a theoretical critic who, in the language of Nietzsche, "im Grunde Bibliothekar und Corrector ist und an Bücherstaub und Druckfehlern elend erblindet". ${ }^{316}$ Settembrini's suspicion of absolute music also relates to Schopenhauer's belief that music is a direct expression of the Will, and that its effect is consequently "so viel mächtiger und eindringlicher, als die der anderen Künste: denn diese reden nur vom Schatten, sie aber vom Wesen". ${ }^{317}$ Nietzsche echoes this idea in Die Geburt der Tragödie, ${ }^{318}$ absorbing the characteristics of Schopenhauer's Will into his own irrational drive Dionysus by describing music as uniquely able to communicate "dionysisch[e] Erkenntnis" and "dionysisch[e] Allgemeinheit". ${ }^{319}$ However, whereas Schopenhauer inadvertently associates music with life (the Will), Nietzsche's Dionysus is both creative and destructive. ${ }^{320}$ Nietzsche's text is thus particularly important to the interpretation of Settembrini's distrust of music because it confirms the potential relation of absolute music to death.

Settembrini's opinion of music is further divided according to its form. His approval of rhythmic and symmetrically phrased music (typical of Classical music and therefore concordant with Settembrini's values) contrasts his description of "bad" music in the chapter section "Politisch verdächtig!":

\footnotetext{
${ }^{314}$ Nietzsche KSA 1, p. 119; see also ibid., p. 126.

${ }^{315}$ Mann 13.1, pp. 59-75.

${ }^{316}$ Nietzsche KSA 1, p. 120.

${ }^{317}$ Schopenhauer I, p. 359. Schopenhauer consequently disapproves of song, arguing that music and speech are like two different languages (ibid., p. 365).

${ }^{318}$ Nietzsche KSA 1, pp. 103-04, 138.

319 Ibid., p. 107.

320 See above, p. 52.
} 
[Die Musik] ist sittlich, sofern sie weckt. Aber wie, wenn sie das Gegenteil tut? Wenn sie betäubt, einschläfert, der Aktivität und dem Fortschritt entgegenarbeitet? Auch das kann die Musik, auch auf die Wirkung der Opiate versteht sie sich aus dem Grunde. Eine teuflische Wirkung, meine Herren! Das Opiat ist vom Teufel, denn es schafft Dumpfsinn, Beharrung, Untätigkeit, knechtischen Stillstand... Es ist etwas Bedenkliches um die Musik, meine Herren [...]. (175)

This passage relates communicatively and selectively to Nietzsche's critique of Wagner, whose music allegedly has the effect of an "Opiat". ${ }^{321}$ Nietzsche's text indicates that Romantic music in particular is associated with death, an insight confirmed by Castorp's own musical taste. In "Fülle des Wohllauts", for example, the sanatorium patients listen together to a range of music: Offenbach's Overture (966), a popular waltz (966), Mozart's The Marriage of Figaro (967), a folk song (968), Verdi's La Traviata, (968), a Romance by Rubenstein (968), dance music (968) and the Barcarole from Offenbach's Hoffmann's Tales (969). However, while alone, Castorp listens almost exclusively to Romantic music: Wagner's Tannhäuser (972), Puccini’s La Bohème (973), Verdi’s Aida (975), Bizet's Carmen (981), Gounod's Faust (984), and Schubert's Der Lindenbaum (985). ${ }^{322}$

Castorp's preference for Romantic vocal music undermines the link established previously between absolute music and death. This anomaly is explained by the primary text's relation to contrasting ideas within the work of Nietzsche. In the previous paragraphs, I linked music in Der Zauberberg to Nietzsche's discussion of both Dionysus (Die Geburt der Tragödie) and Wagner (Der Fall Wagner). By juxtaposing these two texts, the novel reveals their similarities: although Nietzsche himself contrasts Wagner's decadent music with the music of Dionysus, ${ }^{323}$ the Dionysian qualities of dissolution and expansion are concordant with Wagner's ambiguous tonality brought about by chromaticism, with his "unendliche[r] Melodie" (never-ending melody), and with the expansiveness of his works. In Der Zauberberg, this marriage between Dionysus and Wagner continues as the concept of music's special Dionysian power is transferred onto Romantic vocal music.

\footnotetext{
${ }^{321}$ Nietzsche KSA 6, p. 325.

322 Castorp also listens to Debussy's Prélude à l'après-midi d'un faune (979).

${ }^{323}$ Nietzsche KSA 6, p. 357.
} 
In Die fröhliche Wissenschaft, Nietzsche refers to Wagner as "de[n] berühmtesten der lebenden Schopenhauerianer", 324 and in Der Fall Wagner, he claims that Wagner "schmeichelt jedem nihilistischen Instinkte und verkleidet ihn in Musik". 325 This view of Wagnerian music as life negating is transferred in Der Zauberberg to Franz Schubert's Romantic setting of Der Lindenbaum, which Castorp is last heard singing to himself on the battlefield of World War I (1084). The choice of Der Lindenbaum to represent the affirmation of death in music reveals limitations to Thomas Mann's musical knowledge: ${ }^{326}$ the simplicity and symmetry of Schubert's musical setting is not typically Romantic, and might even win Settembrini's approval. Instead, Thomas Mann's choice of Der Lindenbaum is clearly based on the equation of death with peace communicated by Wilhelm Müller's lyrics:

Am Brunnen vor dem Tore / Da steht ein Lindenbaum; Ich träumt' in seinem Schatten / So manchen süßen Traum. Ich schnitt in seine Rinde / So manches liebe Wort; Es zog in Freud' und Leide / Zu ihm mich immer fort. Ich mußt auch heute wandern / Vorbei in tiefer Nacht, Da hab' ich noch im Dunkeln / Die Augen zugemacht. Und seine Zweige rauschten, / Als riefen sie mir zu: Komm her zu mir, Geselle, / Hier find'st du deine Ruh'! Die kalten Winde bliesen / Mir grad' ins Angesicht; Der Hut flog mir vom Kopfe, / Ich wendete mich nicht. Nun bin ich manche Stunde / Entfernt von jenem Ort, Und immer hör ich's rauschen: / Du fändest Ruhe dort! ${ }^{327}$

The death-affirming message of Der Lindenbaum closely resembles that of Novalis's sixth "Hymne an die Nacht":

\footnotetext{
${ }^{324}$ Nietzsche KSA 3, p. 455.

${ }^{325}$ Nietzsche KSA 6, p. 43.

326 Walter Windisch-Laube notes Thomas Mann's narrow musical taste and his overwhelmingly literary relationship to music (W. Windisch-Laube. "Thomas Mann und die Musik", in H. Koopmann (ed.). Thomas Mann Handbuch, op. cit., pp. 327-42, here, pp. 334-37).

327 Thomas Mann describes this song to Agnes Meyer in a letter of 12 January 1943 as "Symbol alles Liebenswert-Verführerischen, worin der heimliche Keim der Verderbnis lauert” (E. Mann (ed.). Thomas Mann Briefe 1937-1947, vol. II, op. cit., pp. 290-91).
} 
[...] / Gelobt sey uns die ewge Nacht, / Gelobt der ewge Schlummer.

Wohl hat der Tag uns warm gemacht, / Und welk der lange Kummer.

Die Lust der Fremde ging uns aus, / Zum Vater wollen wir nach Haus. / [...]. ${ }^{328}$

The intertextual connection of Der Lindenbaum to this "Hymne" underscores the Lied's representation of death in the novel. In addition, the concept of death's release as peace in Müller's poem metatextually parallels Schopenhauer's view of death as “die [...] Ruhe des seligen Nichts". ${ }^{329}$ However, this intertext gives a new angle to the interpretation of death as release in Der Zauberberg, since Schopenhauer believes the peace of death to be fleeting, immediately dispersed by the creation of a new, suffering individual. ${ }^{330}$

Novalis's "Hymne" quoted above suggests that the origin of life's tension is the soul's captivity within the living body. This message is also presented by Novalis in his first "Geistliches Lied": "Ein eisern Band hielt an der Erde / Die bebenden Gefangnen fest". ${ }^{331}$ Novalis's idea is reflected in Der Zauberberg in Naphta's claim that pedagogy should be a matter of "absolute[n] Befehl[s]" and of "eiserne[r] Bindung" (603). However, Naphta himself is described as "der Anwalt der Freiheit" (566), a description that concurs with the link between death and liberation made by Novalis and Schopenhauer. According to Novalis, death is a moment of deliverance, in which Jesus ("ein Befreyer") 332 releases the individual soul into heaven. ${ }^{333}$ Schopenhauer similarly portrays life as imprisonment (actions are determined) and death as temporary liberation. ${ }^{334}$ However, unlike Novalis, this liberation results from death's destruction of the self: "Das Sterben ist der Augenblick jener Befreiung von der Einseitigkeit einer Individualität". ${ }^{335}$ In the context of Novalis and Schopenhauer's texts, Castorp's following exclamation: "Auf den Bergen wohnt die

\footnotetext{
${ }^{328}$ Novalis 1, p. 153.

329 Schopenhauer II, p. 822.

${ }^{330}$ Schopenhauer I, p. 388.

${ }^{331}$ Novalis 1, p. 160.

332 Ibid.

333 Ibid., pp. 135, 147, 155.

${ }^{334}$ Schopenhauer II, p. 398.

335 Ibid., p. 650.
} 
Freiheit!" (582) becomes ambiguous. Does he mean liberation of the self or liberation from the self?

Analysis of Der Zauberberg suggests that the Schopenhauerian concept of liberation from the self dominates. This can be seen in the context of suffering: Naphta's tract De miseria humanae conditionis (594), ${ }^{336}$ for example, presents suffering as inherent to human existence. ${ }^{337}$ Similarly, Dr Krokowski claims in the chapter section "Analyse" that disease is symptomatic of the suffering self (196). ${ }^{338}$ This view of disease corresponds metatextually to the conviction of both Schopenhauer and Nietzsche that the source of pain is the state of individuation. ${ }^{339}$ The suffering self is embodied in Der Zauberberg by the "Persönlichkeit" (835) Mynheer Peeperkorn, the depth of whose pain leads to his description in the novel as "[ein] Schmerzensmann[]" (941). This biblical reference to Christ's burden of the sins of humanity is ironically linked to Peeperkorn's personal insufficiency (his impotence), which in turn reflects Schopenhauer's conviction that personal discontent is "d[er] bitterste[] aller Leiden". ${ }^{340}$ Although Peeperkorn's suicide eliminates the source of his suffering when interpreted according to Schopenhauer's philosophy, ${ }^{341}$ the temporary nature of this release (see above) leads Schopenhauer to counsel against suicide: "[N]ur mit falschem Scheine lockt [...] der finstere kühle Orkus als Hafen der Ruhe". ${ }^{342}$ Nevertheless, since Schopenhauer regards death as rejuvenating for the Will, ${ }^{343}$ Peeperkorn's suicide can be interpreted as his sacrifice of the self for the sake of his God of life.

\footnotetext{
${ }^{336}$ See 2.4, p. 47.

${ }^{337}$ Subsequent passages in Der Zauberberg gently poke fun at this idea: the copy of this tract that Naphta lends Castorp is "ein[] morsche[r] Pappband" (611) ironically suffering along with its content. Similarly, the death-affirming Naphta lives in luxury surrounded by silk plush cushions (592), whereas the life-affirming Settembrini's spartan attic rooms are furnished with a narrow bed, a lectern (i.e. he must stand) and hard chairs (612-13).

338 Krokowski's claim that "das Krankheitssymptom sei verkappte Liebesbetätigung” (196) implies, in agreement with Freud, that the patients' malaise is caused by psychological repression. This theme will be explored in more detail in subchapter 6.1 (see pp. 186-89).

${ }^{339}$ Schopenhauer I, p. 456; see also ibid., pp. 355-56, 422. Nietzsche KSA 1, p. 73; see also ibid., p. 72.

${ }^{340}$ Schopenhauer I, p. 422.

${ }^{341}$ Schopenhauer II, pp. 626-30.

${ }^{342}$ Schopenhauer I, p. 388.

${ }^{343}$ Schopenhauer II, p. 641. See 2.2, p. 32.
} 
The element of self-overcoming present in Peeperkorn's suicide closely parallels two texts by Novalis and Nietzsche. Novalis claims: "Der Act des sich selbst Überspringens ist überall der höchste - der Urpunct - die Genesis des Lebens. So ist die Flamme nichts, als ein solcher Act". ${ }^{344}$ Nietzsche develops this idea in Jenseits von Gut und Böse: "Alle grossen Dinge gehen durch sich selbst zu Grunde, durch einen Akt der Selbstaufhebung: so will es das Gesetz des Lebens, das Gesetz der nothwendigen 'Selbstüberwindung' im Wesen des Lebens". ${ }^{345}$ This positive interpretation of self-overcoming is reflected in the narrator's vision of hope in the chapter section "Der Donnerschlag": "Aber sein [des Todverherrlichen Lieds] bester Sohn [Castorp] mochte doch derjenige sein, der in seiner Überwindung sein Leben verzehrte und starb, auf den Lippen das neue Wort der Liebe, das er noch nicht zu sprechen wußte." (990) This passage anticipates the last scene of the novel, in which Castorp disappears from view on the battlefield of World War I, and in which the narrator's hope for Castorp is transferred onto the German people as a whole: "Wird auch aus diesem Weltfest des Todes [...] einmal die Liebe steigen?" (1085)

However, self-overcoming is also presented in Der Zauberberg as death-affirming. In the chapter section "Forschungen", Castorp's research on the nature of life teaches him that an organism can be receptive to disease, as well as provide bacteria with favourable conditions in which they thrive (431-32). Furthermore, the toxins produced by these bacteria can cause the organism to embrace its own demise: "[M]it wogendem Busen, sozusagen, taumelte [der Organismus] seiner Auflösung entgegen" (432). ${ }^{346}$ These highly referential passages clearly relate to Freud's concept of a Todestrieb (death drive) from the essay "Jenseits des Lustprinzips". ${ }^{347}$ Here, Freud argues that the fundamentally regressive nature of unconscious drives indicates that the goal of life is "ein Ausgangszustand [...], den das Lebende einmal verlassen hat, und zu dem es über alle Umwege der Entwicklung

\footnotetext{
${ }^{344}$ Novalis 2, p. 556.

${ }^{345}$ Nietzsche KSA 5, p. 410. Nietzsche pokes fun at his own idea in Ecce Homo: "Meine Humanität besteht nicht darin, mitzufühlen, wie der Mensch ist, sondern es auszuhalten, dass ich ihn mitfühle... Meine Humanität ist eine beständige Selbstüberwindung” (Nietzsche KSA 6, p. 276).

${ }^{346}$ The relationship between pleasure and the death drive will be discussed in depth in 5.4 (see pp. 176-78).

${ }^{347}$ Freud XIII, p. 53.
} 
zurückstrebt". ${ }^{348}$ Freud also theorises the existence of a life drive; however, this is weak, and merely ensures that the organism dies "auf seine Weise". ${ }^{349}$ Novalis anticipates Freud's idea that the goal of life is death in the following fragment from "Poëticismen" (1797): "Alle Befriedigung ist Selbstauflösung. Bedürfniß entsteht durch Entzweyung - fremden Einfluß - Verletzung. Es muß sich selbst wieder ausgleichen." ${ }^{350}$ The message in this fragment that death is a necessary release of tension is identical to Freud's description of the death drive striving to release the tension inherent in the living organism. ${ }^{351}$ A parallel observation to Freud's conclusion: "Das Ziel alles Lebens ist der Tod [sic]", ${ }^{352}$ can also be found in Novalis's following statement: "Der Trieb unsrer Elemente geht auf Desoxyd[ation]"353 (life is a process of oxidation). Similarly, Schopenhauer states: "Das Sterben ist [...] der eigentliche Zweck des Lebens anzusehn". ${ }^{354}$ Consideration of these intertexts discussed above and the clear portrayal of a death drive in the chapter section "Forschungen" leads the reader to the following conclusion: the "Weltfest des Todes" (1085) portrayed at the end of Der Zauberberg, and Castorp's implied death on the battlefield of World War I are, in a metaphorical equation of life and the novel, the goal towards which the narrative has led from the very beginning.

\footnotetext{
348 Ibid., p. 40.

${ }^{349}$ Ibid., p. 41; see also ibid., p. 43. In Der Zauberberg, this life drive is humorously reflected in "eine[r] besondere[n] Widerstandskraft des lebenden Protoplasmas" that prevents the stomach from digesting itself (427).

350 Novalis 2, p. 562. Thomas Mann acknowledges Novalis's argument in "Von deutscher Republik": “[Novalis] findet das Merkmal aller Krankheit, den Selbstzerstörungsinstinkt, im organischen Stoff” (Mann 15.1, p. 556).

${ }^{351}$ Freud XIII, pp. 60, 68; Freud refers to this death drive as a "Nirwanaprinzip" (ibid., p. 60).

352 Freud XIII, p. 40.

${ }^{353}$ Novalis 3, p. 687. This statement is followed by another: "Das Leben ist eine erzwungne Oxydation." (see earlier in this subchapter) In the speech "Von deutscher Republik", Thomas Mann uses Novalis's fragment to illustrate his concept of death (as Mann understands it) as "[der] Trieb unserer Elemente zur Freiheit, zur Unform und zum Chaos" (Mann 15.1, p. 558), and in the essay "Die Stellung Freuds in der modernen Geistesgeschichte", Mann uses this fragment again to illustrate the relationship between Freud's theory of the death drive and European Romanticism (P. Mendelssohn (ed.). Thomas Mann. Gesammelte Werke in Einzelbänden. Leiden und Größe der Meister, op. cit., p. 901).
}

${ }^{354}$ Schopenhauer II, p. 817; see also Schopenhauer I, p. 429. 


\subsection{The synthesis of life and death}

In the previous subchapter, I demonstrated that the glorification of death in Der Zauberberg outweighs the affirmation of life. This imbalance is addressed in the chapter section "Schnee", in which Castorp wakes from a vision on the mountain concluding that death should not outweigh life:

Ich will dem Tode Treue halten in meinem Herzen, doch mich hell erinnern, daß Treue zum Tode und Gewesenen nur Bosheit und finstere Wollust und Menschenfeindschaft ist, bestimmt sie unser Denken und Regieren. Der Mensch soll um der Güte und Liebe willen dem Tode keine Herrschaft einräumen über seine Gedanken. $(748)^{355}$

Castorp's vision functions similarly to the fairy-tale inserted into the narrative of Novalis's Heinrich von Ofterdingen, which Brandes refers to as "den Schlüssel zum Ganzen". 356 Indeed, Castorp's mediating conclusion on the relative value of life and death is frequently regarded as the essential message of Der Zauberberg. ${ }^{357}$ The present study has shown that the antithesis of life and death is linked to an opposition of Nature and Mind. ${ }^{358}$ Yet according to Novalis, this synthesis of Nature and Mind is synonymous with God, i.e. with death itself:

Willkühr und Zufall sind die Elemente der Harmonie. Willkührliche und zufällige Welt. In beyden Zuständen dasselbe Verhältniß.

Wunder Welt und Naturwelt.

Geisterreich und wirckliche Welt.

Freyer Wechsel dieser beyden Zustände. Willkühr und Zufall Eins. Wunder und

\footnotetext{
355 This concept of synthesis is reiterated by Thomas Mann in the speech "Von deutscher Republik": "Das Interesse für Tod und Krankheit, für das Pathologische, den Verfall ist nur eine Art von Ausdruck für das Interesse am Leben, am Menschen, wie die humanistische Fakultät der Medizin beweist; wer sich für das Organische, das Leben, interessiert, der interessiert sich namentlich für den Tod.” (Mann 15.1, pp. 557-58; see also Der Zauberberg, p. 404)

${ }^{356}$ G. Brandes, op. cit., p. 276.

357 See H. Koopmann. "Die Lehren des Zauberbergs", op. cit., p. 63; H. Wysling. “Der Zauberberg - als Zauberberg", op. cit., pp. 55-57; J. Bade. "The Magic Mountain of Weimar Politics: the Impact of the Assassination of Walther Rathenau on Thomas Mann's Der Zauberberg." In Monatshefte für deutschsprachige Literatur und Kultur, vol. 106, no. 1, 2014, pp. 37-53, here, p. 49.
}

358 See 2.2, p. 31. 
gesetzmäßige Wirckung. Natur und Geist $=$ Gott. ${ }^{359}$

The divine goal in Novalis's synthesis is reflected in Der Zauberberg in Naphta's prediction of a communist uprising "zum Heile der Welt und zur Gewinnung des Erlösungsziels, der staats- und klassenlosen Gotteskindschaft” (609). ${ }^{360}$ Naphta's revolution implicitly transfers mankind's salvation from the afterlife to life. A worldly "Gottesstaat[]" (578) suggests death's conquest of life and its usurpation of life's realm (the world). This is clear from the emphasis on asceticism and domination in Naphta's following statement: "Aber der Dualismus von Gut und Böse, von Jenseits und Diesseits, Geist und Macht muß, wenn das Reich kommen soll, vorübergehend aufgehoben werden in einem Prinzip, das Askese und Herrschaft vereinigt." (607) The Christian basis of Naphta's synthesis can be seen in the reference in Der Zauberberg to The Last Judgement and the Second Coming (961), concepts which Novalis defines as follows: "Der jüngste Tag ist die Synthesis des jetzigen Lebens und (des Lebens nach dem Tode) des Todes."361 This synthesis is part of Novalis's vision of a romanticised world in which "dem Gemeinen ein[] hohe[r] Sinn [gegeben wird]". ${ }^{362}$ Accordingly, in Heinrich von Ofterdingen, the mysterious Astralis recites:

Es bricht die neue Welt herein / und verdunkelt den hellsten Sonnenschein [,] / Man sieht nun aus bemooßten Trümmern / Eine wunderseltsame Zukunft schimmern, / Und was vordem alltäglich war / Scheint jetzo fremd und wunderbar. [...] / Der Liebe Reich ist aufgethan / Die Fabel fängt zu spinnen an. [...] / Wehmuth und Wollust, Tod und Leben / Sind hier in innigster Sympathie - [... . ${ }^{363}$

The metatextual parallel between Novalis's and Naphta's syntheses suggests the infiltration of death into life. Indeed, the reference to "[dem] schrecklichen Jüngsten Tag" (961) in Der Zauberberg appears as a premonition of war and catastrophe, which is realised at the conclusion of the novel in the battle scene of World War I. The relation of this scene to

\footnotetext{
${ }^{359}$ Novalis 2, p. 548.

${ }^{360}$ This contradicts Naphta's previous assertion that salvation is only possible in heaven (578; see 2.4, p. 41).

${ }^{361}$ Novalis 2, p. 562.

${ }^{362}$ Ibid., p. 545.

${ }^{363}$ Novalis 1, pp. 318-19; also quoted in G. Brandes, op. cit., pp. 240-41.
} 
Novalis's text leads to the reader's understanding that in Der Zauberberg, death ultimately conquers life. This interpretation challenges the argument presented by several Mann scholars that Der Zauberberg reflects a development in Mann's philosophy and political ideology away from Schopenhauerian pessimism and the monarchy and towards lifeaffirming humanism and democracy. ${ }^{364}$ Although this development is clear from accompanying smaller works such as the speech "Von deutscher Republik" and the essay "Goethe und Tolstoi", the present thesis shows that in Der Zauberberg, the shift in Mann's ideology fails to be fully realised.

\subsection{Conclusion}

In this chapter, I have demonstrated that the reader's understanding of Der Zauberberg is illuminated by knowledge of texts by Novalis, Schopenhauer, Nietzsche and Freud. Parallels to the work of these thinkers within the novel explain the denial of death at the sanatorium as consequent to society, and indicate that the Christian concept of death as a mystery must be defended against irreverent, (atheist) scientific examination.

Antithetical Christian and atheist views of death are represented in Der Zauberberg by the characters of Naphta and Settembrini. Their views are based on conflicting concepts of Nature/the body and Mind/the soul discussed in texts by Novalis, Schopenhauer, Nietzsche and Freud. Yet intertextual correspondence between these thinkers and the primary text also illuminates the interrelation of Christianity and atheism via the circular concepts of time and reincarnation.

The attitudes of characters in Der Zauberberg towards dying are also informed by Christian and atheist views of death. The fear of death is explained by analysis of the intertexts to be an animal instinct negated by belief in heaven or in reincarnation. The Christian emphasis on the afterlife and consequent affirmation of death is questioned, as is

\footnotetext{
${ }^{364}$ See H. Mayer, p. 93; J. Bade. "The Magic Mountain of Weimar Politics: the Impact of the Assassination of Walther Rathenau on Thomas Mann's Der Zauberberg", op. cit., p. 49. My thesis thus affirms Helmut Koopmann's view of Der Zauberberg as an essentially Romantic novel that contains some life-affirming Classical ideas (H. Koopman. "Die Lehren des Zauberbergs", op. cit., p. 78).
} 
the ascetic fundament to Christianity, which appears as a destructive force with the potential to destroy society.

Christian and atheist interpretations of life and death are shown in Der Zauberberg to correspond to principles of tension and release. The related concept of self-overcoming explored in texts by Novalis, Schopenhauer and Nietzsche leads to the recognition of a death drive in the primary text, the presence of which underscores the affirmation of death within the novel.

The dominant affirmation of death in Der Zauberberg is tempered by the synthesis of death and life in Castorp's vision from the chapter section "Schnee". However, this is undermined by the death-affirmation of Naphta's vision of heaven on earth, as well as by the outbreak of war at the conclusion of the novel. These two scenes closely relate to Novalis's belief in the Christian Final Judgment and Second Coming, and, together with the predominance of death-affirmation within the rest of the novel, confirm that Der Zauberberg, while expounding on the dangers of death, never escapes from its spell. 


\section{Chapter 3. Disease and life}

\subsection{The nature of life: receptivity to stimuli}

The previous chapter examined the relation of life to death in Der Zauberberg, focusing on the nature of death as well as exploring death's meaning for life. Primarily investigating the sections "Humaniora", "Forschungen" and "Totentanz" that conclude chapter five of the novel, the present chapter of the thesis balances the equation by focusing on life itself. In "Forschungen", Hans Castorp poses the question "[w] as war das Leben?" (416), to which he concludes: "Niemand wußte es." (417) The present chapter looks at how this negative conclusion is subverted by the intertextuality of the primary text, and examines intertextual connections to the work of Novalis, Schopenhauer, Nietzsche and Freud that reveal positive answers to Castorp's existential question.

In the chapter section "Humaniora", Director Behrens approaches Castorp in the garden smoking a cigar, and, seeing a cigar in Castorp's own hand, he starts up a conversation about the pleasures and dangers of tobacco. However, Castorp soon interrupts the director by changing the subject to art: "Sie malen doch manchmal, Herr Hofrat" (386). Fuelling this polite interest is Castorp's burning desire to see the portrait of Madame Chauchat that Director Behrens has allegedly painted. Castorp's plan succeeds: flattered by the interest in his work, Behrens invites the cousins into his apartment to view his paintings. Castorp catches sight of Chauchat's portrait almost immediately, and with feigned surprise - “[d]a ist doch ein bekanntes Gesicht?" (389) - he initiates a discussion of the painting, during which he removes the portrait from the wall on the pretence of admiring it in a different light. Although the portrait displays many amateur flaws, Behrens has succeeded in depicting the skin of Chauchat's bosom with extraordinary vividness (and attention to detail) (392-93). Her décolletage becomes the focus of a conversation that introduces the themes of the skin and its characteristics; over coffee, the portrait leaning against his knee, Castorp asks Behrens to explain skin from a biological perspective, and Behrens obliges:

$\mathrm{Na}$, von der Haut? Was soll ich Ihnen denn von Ihrem Sinnesblatt erzählen. Das ist Ihr Außenhirn, verstehen Sie, - ontogenetisch ganz desselben Ursprungs wie der Apparat für die sogenannten höheren Sinnesorgane da oben in Ihrem Schädel: das zentrale Nervensystem, müssen Sie wissen, ist bloß eine leichte Umbildung der 
äußeren Hautschicht, und bei den niederen Tieren, da gibts den Unterschied zwischen zentral und peripher überhaupt noch nicht, die riechen und schmecken mit der Haut, müssen Sie sich vorstellen, die haben überhaupt bloß Hautsinnlichkeit [...]. Dagegen bei so hoch differenzierten Lebewesen, wie Sie und ich, da beschränkt sich der Ehrgeiz der Haut auf die Kitzlichkeit, da ist sie bloß noch Schutz- und Meldeorgan, aber höllisch auf dem Posten gegen alles, was dem Körper zu nahe treten will, - sie streckt ja sogar noch Tasteapparate über sich hinaus, die Haare nämlich, die Körperhärchen, die bloß aus verhornten Hautzellen bestehen und eine Annäherung schon spüren lassen, bevor die Haut selbst noch berührt ist. (399)

Roughly summarised, this passage describes the skin's sensitivity to the stimulation of touch. However, the significance of this sensitivity is only revealed by intertextual analysis, which indicates that Behrens' description of the skin corresponds selectively to the essay "Jenseits des Lustprinzips". Here, Freud discusses the relationship of the living organism to stimuli by inviting his reader to imagine life in its simplest form - a primitive "Bläschen reizbarer Substanz". ${ }^{365}$ The surface of this little bubble absorbs and deflects external stimuli, and it is thus clearly the prototype for the skin and its characteristic sensitivity in "Humaniora". This intertextual relationship is especially clear if the reader is aware of the following selective metatextual parallels within Behrens' monologue. Behrens' description of the skin's genetic similarity to the central nervous system, for example, corresponds to Freud's note that both the central nervous system and the brain develop from the embryological "Ektoderm". ${ }^{366}$ The ability of simple organisms to smell and taste with their epidermis relates to the fact that the surface of Freud's bubble is its single sensory organ, ${ }^{367}$ and Behrens' comparison of these organisms with human beings parallels Freud's relation of his simple bubble to more complicated organisms within which the stimuli-absorbing surface has developed into senses. ${ }^{368}$ Lastly, Behrens' portrayal of human skin as "[ein] Schutz- und Meldeorgan" reflects the function of the surface of Freud's bubble to regulate

\footnotetext{
365 Freud XIII, p. 25.

${ }^{366}$ Ibid. This fact is also noted by Nietzsche in a fragment from 1883 (Nietzsche KSA 10, p. 404).

${ }^{367}$ Freud XIII, p. 25.

${ }^{368}$ Ibid., p. 27. Castorp similarly learns of the human body in the chapter section "Forschungen": "[Das] Ich [sei] eine Lebenseinheit von hoher Ordnung [...], bei weitem nicht mehr von der Art jener einfachsten Wesen, die mit ihrer ganzen Körperoberfläche atmeten, sich ernährten und sogar dachten" (420).
} 
the amount of stimuli that penetrates the organism. ${ }^{369}$ These metatextual connections to Freud's essay "Jenseits des Lustprinzips" are of particular importance for the reader's interpretation of skin in "Humaniora" because they indicate a relationship between sensitivity and life. Freud uses his little bubble to illustrate the fact that all living organisms are receptive to stimuli; ${ }^{370}$ the little bubble thus embodies life's basic characteristics. The intertextual link of Freud's bubble to the portrayal of skin in "Humaniora" suggests that skin and its ticklishness might also be intended to represent life in Der Zauberberg.

This hypothesis is strengthened by the intertextual relation of skin and its sensitivity to the work of Novalis. In a fragment from 1798, Novalis notes the following: "[D]as Auge, das Ohr und die Haut!!! [...] [sind afficirt] von den Medien ihrer Gegenstände - den Incitamenten [stimuli]". ${ }^{371}$ This passage appears among several fragments that anticipate Freud's little bubble by characterising living organisms as receptive to stimuli. ${ }^{372}$ Novalis defines organic material as "das Erregbare", 373 and describes the human body caught "in der Abhängigkeit von äußern Reizten, deren Inbegriff wir die Natur oder die äußre Welt nennen". ${ }^{374}$ This definition of life is indebted to the medical system of the Scotsman John Brown (1735-1788), who divides life into the following two elements: excitability (sensitivity to stimuli) and stimulation. ${ }^{375}$ Brown's theory leads Novalis to declare: "Der Eine Factor ist ein Lebendiges (Erregbares) - der andere Leben (Reitz) [...]. Das Produkt ist Leben." ${ }^{376}$ By describing life as the product of a relationship between an excitable body and stimuli, Novalis's fragments further indicate the skin's representation of life in Der Zauberberg.

\footnotetext{
${ }^{369}$ Freud XIII, pp. 26-27.

${ }^{370}$ Ibid., p. 25.

${ }^{371}$ Novalis 2, p. 541.

372 Ibid., pp. 555, 556-57.

373 Ibid., p. 555.

${ }^{374}$ Ibid., p. 546. Castorp's study of biology in the chapter section "Forschungen" teaches him that a function of bodily organs is "Reizmeldung und Reizentsendung”. This recalls Novalis's description of the eyes', ears' and skin's function to "leiten [Reize] - heraus und hinein" (ibid., p. 541).

375 J. Brown. Elementa Medicinae (1780), referred to in J. Neubauer. "Dr John Brown and early German Romanticism", in Journal of the History of Ideas, vol. 28, no. 3. Pennsylvania: University of Pennsylvania Press, 1967, pp. 367-82, here, p. 369.
}

376 Novalis 2, p. 556. 
The chapter section "Forschungen" relates further to Novalis's and Freud's ideas on the nature of life by equating excitability with consciousness:

Was war das Leben? Man wußte es nicht. Es war sich seiner bewußt, unzweifelhaft, sobald es Leben war, aber es wußte nicht, was es sei. Bewußtsein als Reizempfindlichkeit, unzweifelhaft, erwachte bis zu einem gewissen Grade schon auf den niedrigsten, ungebildetsten Stufen seines Vorkommens [...]. (416)

However, the statement that life became conscious "sobald es Leben war" indicates that life preceded consciousness. In a subsequent passage that declares the possibility of anaesthetising an organism's excitability (consciousness), consciousness is similarly presented as "eine Funktion der zum Leben geordneten Materie" (416). These extracts from "Forschungen" dialogically oppose Novalis's and Freud's interpretation of excitability as a basic element of life, and concur instead with the following statement from Schopenhauer's Die Welt als Wille und Vorstellung:

[S]tets hat das Bewußtsein sich mir nicht als Ursache, sondern als Produkt und Resultat des organischen Lebens gezeigt, indem es in Folge desselben stieg und sank, nämlich in den verschiedenen Lebensaltern, in Gesundheit und Krankheit, in Schlaf, Ohnmacht, Erwachen u.s.w., also stets als Wirkung, nie als Ursache des organischen Lebens. ${ }^{377}$

Schopenhauer considers life's prerequisite to be the Will, ${ }^{378}$ a life force very similar to the life-enabling stimuli proposed by Novalis and Freud. Taking this similarity into account, Schopenhauer's belief that consciousness is a product of life can be understood as a variation of Novalis's and Freud's theories: without stimuli, there is nothing to be conscious of; the Will must therefore pre-empt consciousness. However, whereas Schopenhauer's view of life can be summarised as follows: stimuli (Will) - life - excitability/consciousness, Novalis and Freud present these factors in a different order: stimuli + excitability/consciousness $=$ life. This last sequence is illustrated by Freud's conviction that

\footnotetext{
377 Schopenhauer II, p. 600.

378 Ibid.
} 
life is a form of tension caused by stimuli penetrating matter. ${ }^{379}$

Nevertheless, the differing interpretations of consciousness presented by Novalis, Schopenhauer and Freud are reconciled in the chapter section "Forschungen" in the statement that excitability/consciousness is present "bis zu einem gewissen Grade schon auf den niedrigsten, ungebildetsten Stufen seines [des Lebens] Vorkommens" (416) (see above). This passage corresponds selectively to Novalis's metaphoric “Leiter des Lebens", a gradation of excitability from the inorganic to human beings. ${ }^{380}$ The skin of Freud's little bubble in "Jenseits des Lustprinzips" likewise demonstrates the presence of excitability/consciousness at a primitive level (in a single-celled organism). ${ }^{381}$ This gradation of life is crowned by people: Novalis positions humans at the top of the ladder of life due to their sophisticated excitability. ${ }^{382}$ For Schopenhauer, the last link in the chain of life is similarly “die tierische Sensibilität, das Erkennen", ${ }^{383}$ and he consequently describes human beings as "[das] höchst[e] Grad [des Willens] Objektivation". ${ }^{384}$ An intertextual link to these texts in "Forschungen" appears in the depiction of the human mind as "[eine] höhere[] Verstärkung” of animal consciousness (416).

The role of stimuli to trigger both consciousness and life is explored further in Der Zauberberg in the portrayal of the living organism as dependent on nourishment. While researching the nature of life in "Forschungen", Castorp reads about the gastrula, a stage in embryonic development during which the blastocyst folds inwards to become a primitive intestine (423). This early formation of the digestive system indicates the importance of external stimuli (nourishment) for life, and thus relates to the alliance of stimuli with growth and change discussed in texts by Novalis, Schopenhauer and Freud. In a fragment from "Poëticismen", for example, Novalis credits external stimuli with enabling development: "Indirecter Reitz [external stimuli], Aufhebung des Gleichgewichts, Heterogenisierung,

\footnotetext{
${ }^{379}$ Freud XIII, p. 60.

${ }^{380}$ Novalis 2, p. 556. See also 2.2, pp. 31-32. Schopenhauer also notes this materialist conception of life, "aufsteigend vom bloßen Mechanismus zum Chemismus, zu Polarität, Vegetation, Animalität” (Schopenhauer I, p. 62).

${ }^{381}$ Freud XIII, pp. 25-26.

382 Novalis 2, p. 556.

${ }^{383}$ Schopenhauer I, p. 62.

${ }^{384}$ Ibid., pp. 222, 224.
} 
bestimmte Richtung". 385 Similarly, Schopenhauer states in Die Welt als Wille und Vorstellung: "[A]uf Reize [...] gehn alle eigentlich organischen und vegetativen Veränderungen im tierischen Leibe vor". ${ }^{386}$ Freud presents an identical argument in "Jenseits des Lustprinzips": "[A]lle Erfolge der organischen Entwicklung [müssen wir] auf die Rechnung äußerer, störender und ablenkender Einflüsse setzen”. 387

These intertexts also give the reader insight into the significance of nourishment for the patients of sanatorium Berghof, who devote a large part of the day to eating two breakfasts, lunch, afternoon tea and supper. Each of these meals is generous: in the chapter section "Natürlich, ein Frauenzimmer!", Castorp sits down to a six-course lunch consisting of soup, fish, meat, vegetables, poultry, and pudding rounded off by cheese and fruit (117). The enormous quantity of food provided is matched by the appetite of the patients ("ein Löwenappetit herrschte im Gewölbe" [117]). Yet this appetite is shared by all patients whether mildly or seriously ill, and thus negates the usual association of appetite with health. The apparent compatibility of extreme hunger and disease is not explained, and this heuristic gap impels the reader to search for answers outside of the primary text. An explanation is provided by Novalis's discussion of pathological aberrations in an organism's excitability. Indirekte Asthenie (indirect asthenia), for example, is a state of deficient excitability characterised by lethargy and weakness. ${ }^{388}$ The wasting effects of tuberculosis mean that this definition of indirect asthenia relates closely to the physical state of the sanatorium patients. According to Novalis, indirect asthenia is treatable with "reitzenden Substanzen", 389 for example alcohol or opiates. ${ }^{390}$ Significantly for the interpretation of Der Zauberberg, indirectly asthenic patients in the late $18^{\text {th }}$ century were also prescribed a diet of rich food. ${ }^{391}$ Knowledge of Novalis's views allows the reader to

\footnotetext{
385 Novalis 2, p. 561.

${ }^{386}$ Schopenhauer I, p. 177.

${ }^{387}$ Freud XIII, p. 39.

${ }^{388}$ Novalis 2, p. 573.

389 Ibid., p. 602.

390 J. Neubauer, op. cit., p. 370.

391 Ibid. In Der Zauberberg, the character Mynheer Peeperkorn peps up his failing strength according to Brownian principles with coffee, rich food and alcohol (see 826-39, 868-947).
} 
interpret the extreme hunger ("[den] übergewöhnliche[n] Appetit" [412]) of the sanatorium patients as symptomatic of their exhausted state, an instinctual attempt to counteract a lack of excitability by increasing their absorption of stimuli. The English patient Miss Robinson's partiality to "blutfarbene[m] Tee" (70) (rosehip) clearly illustrates, following the association of nourishment with blood symbolic of life, this desire to redress the lack associated with disease by absorbing stimuli.

Oxygen is also used in Der Zauberberg to illustrate the need of the chronically ill for life-giving stimuli. In the chapter section "Er versucht sich in französischer Konversation", terminally-ill patients inhale pure oxygen to effect "ein[e] letzt[e] Anfeuerung und Hinhaltung ihrer Kräfte" (163). Further passages in Der Zauberberg equate air with food, and thus relate to the following fragments by Novalis: "Das Essen ist [...] ein accentuirtes Leben"; 392 "Luft ist Lebensluft". ${ }^{393}$ The dying patients, for example, "schlürf[en] [Sauerstoff] durch einen Schlauch" (163), an action that suggests slurping liquid through a straw, and Director Behrens refers to a patient who has been inhaling a great quantity of oxygen as "[einen] Schlemmer" (163). This equivalence of oxygen and nourishment in the novel highlights the function of both to stimulate life, and consequently underscores the intertextual link to Novalis's and Freud's theories of life as a meeting point of excitability and stimuli. In the context of disease, the intertextual analysis from the previous paragraphs leads to the interpretation of sanatorium Berghof as a microcosm of the natural world, a metaphorical petri-dish in which the tuberculosis patients illustrate the diseased organism's relationship to stimuli.

\subsection{Stimuli, determinism and heredity}

The living organism's dependence on external stimuli discussed in the previous subchapter is a concept related to the discussion in "Humaniora" of the individual's influence by the external world. To Behrens' enquiry why Castorp chose to become an engineer, Castorp replies: "Aus Zufall. Das waren wohl mehr oder weniger die äußeren Umstände, die darin den Ausschlag gaben.” (399) This statement relates metatextually to Schopenhauer's claim

\footnotetext{
392 Novalis 2, p. 618; see also ibid., p. 540.

${ }^{393}$ Novalis 3, p. 110. Joachim's description of oxygen as “Lebensgas” (441) also echoes Novalis's fragment.
} 
in Die Welt als Wille und Vorstellung that decisions are influenced "von den Umständen, in die ihn [den Menschen] das Schicksal setzte, von den Umgebungen, von den äußern Einflüssen". ${ }^{394}$ Castorp's particular use of the word "coincidence" corresponds selectively to the text Morgenröte, in which Nietzsche discusses "[ein] Reich der Zufälle"395 that he subsequently unveils as synonymous with necessity:

Jene eisernen Hände der Nothwendigkeit, welche den Würfelbecher des Zufalls schütteln, spielen ihr Spiel unendliche Zeit: da müssen Würfe vorkommen, die der Zweckmässigkeit und Vernünftigkeit jedes Grades vollkommen ähnlich sehen. Vielleicht sind unsere Willensacte, unsere Zwecke nichts Anderes, als eben solche Würfe $\left[\ldots . . .{ }^{396}\right.$

This combination of coincidence and necessity is echoed by Freud in his own view of "d[er] Aufteilung unserer Lebensdeterminierung zwischen den 'Notwendigkeiten' unserer Konstitution und den 'Zufälligkeiten' unserer Kindheit'. 397 The determinism expressed in these texts by Schopenhauer, Nietzsche and Freud is reproduced within the plot of Der Zauberberg. Castorp remains at the sanatorium for seven years before his release back into the world by circumstance (military conscription), and Joachim's attempt to change his destiny by leaving the sanatorium (633-60) actually accelerates his demise from tuberculosis.

A connection between external determinants and the psyche is revealed by analysis of Castorp's following declaration in the chapter section "Humaniora":

Mir gruselt es sogar ziemlich leicht, bei den verschiedensten Gelegenheiten. Was mich wundert, ist nur, daß die Drüsen bei so verschiedenen Gelegenheiten sich aufrichten. Wenn einer mit einem Griffel über Glas führt, so kriegt man eine Gänsehaut, und bei besonders schöne Musik kriegt man auch plötzlich eine, und als ich bei meiner Konfirmation das Abendmahl nahm, da kriegte ich eine über die andere, das Graupeln und Prickeln wollte gar nicht mehr aufhören. (401)

\footnotetext{
${ }^{394}$ Schopenhauer I, p. 207.

${ }^{395}$ Nietzsche KSA 3, p. 120. Nietzsche suggests that the concept of free will is both "eingebildet" (ibid., p. 122) and "erfunden" (Nietzsche KSA 6, p. 374).

${ }^{396}$ Nietzsche KSA 3, p. 122. This text closely follows Schopenhauer's conception of life as "ein zweckloses [...] Spiel einer ewigen Nothwendigkeit" (Schopenhauer II, p. 413).

${ }^{397}$ Freud VIII, p. 210.
} 
This passage describes the following process: external stimuli (high-pitched squeaking/the sound of music/the feeling of a wafer on the tongue) trigger an internal response (discomfort/pleasure/religious awe) that then causes a physical reaction (goose bumps). This sequence affirms texts by Novalis, Schopenhauer, Nietzsche and Freud that trace internal (psychological) processes to external stimuli. Novalis claims: "Sensibilitaet und innrer Reitz (Seele) beziehn sich [...] [auf] äußrer Reitz - oder Welt". ${ }^{398}$ Schopenhauer similarly believes that the Will acts according to "Ursachen, die [...] Reize heißen". ${ }^{399}$ In Morgenröte, Nietzsche declares that inner drives "nichts Anderes thun, als die Nervenreize interpretieren und nach ihrem Bedürfnisse deren "Ursachen" ansetzen". 400 Freud also expresses interest in the relationship between external and internal stimuli, claiming: “Höherentwicklung wie Rückbildung könnten beide Folgen der zu Anpassung drängenden äußeren Kräfte sein und die Rolle der Triebe könnte sich für beide Fälle darauf beschränken, die aufgezwungene Veränderung als innere Lustquelle festzuhalten. ${ }^{401}$ These texts describe the activation of internal mechanisms by external stimuli, and thus reiterate on a more complex level the primal reaction of matter to the irritation of life-giving stimuli.

Immediately before Castorp's monologue quoted above, Director Behrens explains goose bumps as a response to fear (400-01). This suggests that the inner stimuli responsible for Castorp's goose bumps may be emotional, an interpretation that recalls a fragment by Novalis from 1798. Here, Novalis notes physical reactions to the emotions of shame, fear, shock, sadness, anger, jealousy and joy; ${ }^{402}$ however, these emotions are themselves awoken by more primal inner stimuli that Novalis terms Geist. ${ }^{403}$ Novalis explains the relationship between Geist and the soul as follows: "[Die Seele] steht ursprünglich in der Abhängigkeit eines Inbegriffs innerer Reitze, den wir den Geist nennen". ${ }^{404}$ This relationship is mirrored

\footnotetext{
${ }^{398}$ Novalis 3, pp. 331-32.

${ }^{399}$ Schopenhauer I, p. 176.

${ }^{400}$ Nietzsche KSA 3, p. 113.

${ }^{401}$ Freud XIII, p. 44; see also Freud V, p. 67.

402 Novalis 2, p. 583.

403 Ibid.

${ }^{404}$ Ibid., p. 546; see also ibid., p. 562.
} 
in Freud's following observation of the drives and the psyche: "[D]er Trieb sei ein Reiz für das Psychische". ${ }^{405}$ Knowledge of these texts leads the reader of Der Zauberberg to wonder: might the inner stimuli that cause Castorp's goose bumps also be more primal than emotions? Analysis of his monologue quoted earlier supports this idea. The "most diverse occasions" in which Castorp breaks out in goose bumps indicate that goose bumps are arbitrary, as does Behrens' subsequent observation: “Reiz ist Reiz. Der Inhalt des Reizes kümmert den Körper den Teufel was. Ob Gründlinge oder Abendmahl, die Talgdrüsen richten sich eben auf." (401) The link between goose bumps and irrationality in these passages reveals a strong metatextual connection to the irrational inner stimuli discussed by Schopenhauer, Nietzsche and Freud. Schopenhauer believes that voluntary and involuntary physical reactions follow "das blinde Wirken des Willens". ${ }^{406}$ Nietzsche modifies this idea in his concept of Triebe (inner drives), ${ }^{407}$ and both Schopenhauer's and Nietzsche's ideas anticipate Freud's theory of irrational unconscious drives. ${ }^{408}$ These texts ironically negate Castorp's interpretation of a multiplicity of causes. In an interesting example of Pfister's concept of dialogicity, the surface layer of textual meaning (the varied causes of goose bumps) clashes with the deeper layer of meaning introduced by the intertexts, in which goose bumps are actually triggered by the inner drives (a single cause).

The musical and religious experiences that stimulate Castorp's goose bumps allow the reader insight into the relation of these irrational inner drives to death. In chapter two of this thesis, I demonstrated that both Romantic music and Christianity are used in Der Zauberberg to symbolise death-affirmation. ${ }^{409}$ Consequently, Castorp's goose bumps while listening to music and at his confirmation can be traced to his attraction to death, ${ }^{410}$ and the inner stimulus behind these reactions is revealed to be the death drive present within all living creatures. ${ }^{411}$

\footnotetext{
${ }^{405}$ Freud X, p. 211.

${ }^{406}$ Schopenhauer I, p. 224; see also ibid., pp. 167-68, 222, 417, Schopenhauer II, p. 607.

${ }^{407}$ Nietzsche KSA 3, pp. 111-14.

${ }^{408}$ Freud X, pp. 210-15.

${ }^{409}$ See 2.4 , pp. 43-44; 2.5 , pp. 54-55.

${ }^{410}$ See 2.4 , pp. 44-47.

${ }^{411}$ See 2.5 , pp. 60-61.
} 
This death drive not only triggers Castorp's physical reactions, but also influences his behaviour. Although the reader of Der Zauberberg initially has the impression that Castorp has travelled to sanatorium Berghof in order to visit his cousin Joachim, this supposition is proved false in the chapter section "Bei Tienappels. Und von Hans Castorps sittlichem Befinden". Here, the narrator reveals that Castorp's journey was prompted by his doctor's opinion: "Dr. Heidekind [...] forderte Luftveränderung [...], und wenn man ihn frage, so gehörte Hans Castorp [...] für ein paar Wochen ins Hochgebirge" (59). Castorp's obedience is itself an illusion unmasked by the following fragment by Novalis: “Genaue Beobachtung des ersten Moments der Vellëitaet - der gleichsam der Keim ist wird uns überzeugen, daß hier schon alles drin liegt, was sich nachher nur entwickelt." ${ }^{412}$ Knowledge of this text leads the reader to conclude that Castorp's journey to the sanatorium has also been initiated by his affirmation of death. ${ }^{413}$

The control of Castorp's actions by his death drive illustrates the view held by Schopenhauer, Nietzsche and Freud that unconscious drives dominate the intellect. According to Schopenhauer, the intellect is destined "[de]m Willen [...] beim Verfolgen seiner kleinlichen Zwecke dienstbar zu sein". ${ }^{414}$ Nietzsche similarly maintains: "Der Intellekt ist das Werkzeug unserer Triebe und nichts mehr". ${ }^{415}$ Freud concludes in "Zur Psychopathologie des Alltagslebens" (1901) that actions are motivated by the unconscious drives either directly, or indirectly via the intellect. ${ }^{416}$ The message of these texts is reflected in Der Zauberberg in the chapter section "Vom Gottesstaat und von übler Erlösung", in which Naphta declares: "Ich glaube, damit ich erkenne" (599). This sequence of belief and then knowledge is clarified as connected to Schopenhauer's hierarchy of Will and intellect in a subsequent passage that reveals belief to be one with volition:

Der Glaube ist das Organ der Erkenntnis und der Intellekt sekundär. Ihre voraussetzungslose Wissenschaft ist eine Mythe. Ein Glaube, eine Weltanschauung, eine Idee, kurz: ein Wille ist regelmäßig vorhanden, und Sache der Vernunft ist es,

\footnotetext{
412 Novalis 2, p. 563.

${ }^{413}$ See 2.4 , pp. 44-47.

${ }^{414}$ Schopenhauer II, p. 607.

${ }^{415}$ Nietzsche KSA 9, p. 229.

${ }^{416}$ Freud IV, pp. 282-83.
} 
ihn zu erörtern, ihn zu beweisen. (599)

The subordinate role of the intellect in this passage negates the possibility of free will. Naphta's theory is consequently challenged by Settembrini, who advises Castorp: "[D]er Geist [ist] souverän [...], sein Wille ist frei, er bestimmt die sittliche Welt" (620). However, Settembrini's view is refuted both by the determinism of Castorp's actions mentioned earlier, and by the revelation that even acts of apparent free will in Der Zauberberg are an illusion. In the chapter section "Totentanz", for example, the Herrenreiter attempts to avoid death by leaping out of bed (442), ${ }^{417}$ an action motivated by the Will to live.

The inner drives are also responsible for determining individual character. Schopenhauer claims: “[D]ie Person [...] ist nie frei, obwohl sie die Erscheinung eines freien Willens ist: denn eben von dessen freiem Wollen ist sie bereits determinierte Erscheinung". ${ }^{418}$ This text is echoed in Der Zauberberg by Settembrini, who declares that a young person is no tabula rasa but rather "ein Blatt, auf dem [...] alles schon geschrieben steht” (154). Settembrini's conviction also relates to the following fragment by Novalis: "Wie kann ein Mensch Sinn für etwas haben, wenn er nicht den Keim davon in sich hat? Was ich verstehn soll, muß sich in mir organisch entwickeln; und was ich zu lernen scheine, ist nur Nahrung, Inzitament des Organismus." ${ }^{419}$ Novalis's idea anticipates Schopenhauer's belief in the necessity of actions as products of character. ${ }^{420}$ In Menschliches, Allzumenschliches, Nietzsche similarly argues: "[U]nser Wesen [ist] die Ursache, dass wir so und so denken und urtheilen". 421

The determined character discussed in these texts is linked to heredity in Der Zauberberg. In the chapter section "Von der Taufschale und vom Großvater in zwiefacher Gestalt", for example, the narrator notes that young children observe adults "um zu lernen

\footnotetext{
417 See 2.3, pp. 37-38.

418 Schopenhauer I, p. 398. Similarly, Schopenhauer writes of “der Unveränderlichkeit des Charakters” (Schopenhauer II, p. 759), a statement echoed by Nietzsche in Morgenröte (" $\mathrm{d}[\mathrm{ie}]$ Lehre von der Unveränderlichkeit des Charakters" [Nietzsche KSA 3, p. 326]).

${ }^{419}$ Novalis 2, p. 419; see also ibid., pp. 565-66.

${ }^{420}$ Schopenhauer I, pp. 398-400.

${ }^{421}$ Nietzsche KSA 2, p. 345; see also Nietzsche KSA 1, pp. 56-57. Joachim's particular dislike of Naphta's character ("er selbst hat mich wenig gefallen" [582]) recalls these texts by Nietzsche and Schopenhauer.
} 
und auszubilden, was erblicherweise in ihnen vorgebildet liegt" (41). The link between genealogy and character is also evident from a certain "Sympathie" (41) between Castorp and his grandfather ("ein[e] Nächstverbundenheit und Wesensverwandtschaft" [41]). These shared characteristics relate metatextually to the following fragment by Novalis: "Wir tragen die Lasten unsrer Väter, wie wir ihr Gutes empfangen haben, und so leben die Menschen in der That in der ganzen Vergangenheit und Zukunft nirgends weniger als in der Gegenwart." 422 Nietzsche is similarly convinced: "[E]in Mensch [hat] die Eigenschaften und Vorlieben seiner Eltern und Altvordern im Leibe". ${ }^{423}$ Freud not only acknowledges the influence of heredity on "Denkdisposition" but also on "Triebdisposition". ${ }^{424}$ This last text in particular deepens the reader's understanding of Castorp's character. Following the death-affirmation inherent in the grandfather's conservatism, ${ }^{425}$ it appears that the sympathy with death/death drive that steers Castorp's actions is an inherited trait.

The determined nature of the world is reflected in Castorp's passive acceptance of both his diagnosis with tuberculosis and his later re-diagnosis with streptococcus (949). This affirms Novalis's belief that the intellect must accept the will of God (i.e. of fate), ${ }^{426}$ a view concordant with his philosophy of Quietism shared by Schopenhauer ${ }^{427}$ and arguably modified by Nietzsche in his concept of amor fati. ${ }^{428}$ A superficial reading of Der Zauberberg can leave the reader impatiently waiting for Castorp to take some initiative. Knowledge of the intertexts discussed above enables the reader to accept Castorp's passivity as a philosophical stance appropriate to a world in which life is determined by both internal and external stimuli.

\footnotetext{
${ }^{422}$ Novalis 3, p. 690; see also ibid., p. 323.

${ }^{423}$ Nietzsche KSA 5, p. 219.

${ }^{424}$ Freud XVI, p. 206. According to Freud, inherited traits impact on the individual in conjunction with external influences (ibid., p. 86).

425 See 2.4, p. 49 (footnote 284).

${ }^{426}$ Novalis 2, p. 552.

${ }^{427}$ See 2.5 , p. 50 .

${ }^{428}$ See 2.4, p. 48.
} 


\subsection{Health, disease and the organism}

In the chapter section 'Humaniora", Director Behrens' description of goose bumps as "zweckmäßige Schutzmittel [...], Abwehrreflexe des Körpers" (400) subverts the relationship of life to stimuli discussed in the previous section by suggesting that stimuli can potentially threaten an organism's health:

Wissen Sie, wie Sie eine Gänsehaut kriegen? [...]. Das ist nämlich eine Veranstaltung der Hauttalgdrüsen [...]. Diese Hautsalbendrüsen haben kleine organische Muskeln, die die Drüsen aufrichten können, und wenn sie das tun, dann wird Ihnen wie dem Jungen, dem die Prinzessin den Eimer mit Gründlingen über den Leib goß, wie ein Reibeisen wird Ihre Haut, und wenn der Reiz stark ist, so richten auch die Haarbälge sich auf, - die Haare sträuben sich Ihnen auf dem Kopf und die Härchen am Leibe, wie einem Stachelschwein, das sich wehrt, und sie können sagen, Sie haben das Gruseln gelernt. (400-01)

The defence of the body against external and internal stimuli ("Gründlingen" and "Gruseln") depicted in this passage strongly reflects texts by Freud, Novalis and Nietzsche. ${ }^{429}$ In a discussion of stimuli absorption and deflection in the psyche that develops from ideas introduced by his little bubble, ${ }^{430}$ Freud comes to the conclusion in "Jenseits des Lustprinzips" that health is dependent on the ability of human beings to process stimuli. ${ }^{431}$ The key to this processing is the ability of the organism to "bind" stimuli, that is, to translate free energy into inactive energy. ${ }^{432}$ Related ideas can be found in texts by Novalis and Nietzsche. Novalis, for example, describes the individual's perception of the world as a process of assimilation, "eine Zueignung oder Verwandlung einer andern Substanz in die meinige". ${ }^{433}$ Nietzsche, on the other hand, is cautious about contact with

\footnotetext{
${ }^{429}$ This passage also clearly echoes the Grimm brothers' tale "Märchen von einem, der auszog, das Fürchten zu lernen", in which the hero finally learns fear when his wife tips a bucket full of minnows on him while he is sleeping (Brüder Grimm. Kinder- und Hausmärchen, vol. 1. Stuttgart: Philipp Reklam, 1980, pp. 41-51.).

${ }^{430}$ See 3.1, pp. 68-69.

${ }^{431}$ Freud XIII, p. 31; see also ibid., p. 25.

${ }^{432}$ Ibid., p. 31.

${ }^{433}$ Novalis 2, p. 551; see also ibid., p. 557.
} 
the external world: “[E]in wohlgerathner Mensch [...] prüft den Reiz, der herankommt, er ist fern davon, ihm entgegenzugehn". ${ }^{434}$

Whereas the senses form a barrier between the organism and the world and can consequently regulate the amount of penetrating stimuli, ${ }^{435}$ Freud states that no such barrier exists to regulate internal stimuli. ${ }^{436}$ This idea is anticipated by Novalis in the following fragment: "Der Reitz von Außen ist indirecter, der Reitz von Innen directer Reitz". ${ }^{437}$ The direct access of internal stimuli means that they are potentially dangerous to the organism. However, Freud theorises that the individual can translate the "primary" process of drives rising up into the unconscious into a "secondary" one, whereby external stimuli are filtered through the senses and perceived consciously. Freud terms this process Projektion, ${ }^{438}$ a concept that helps to explain Director Behrens' definition of goose bumps as a physical defence mechanism caused by fear. ${ }^{439}$ In the light of Freud's text, the skin's reaction to fear as if to external cold in "Humaniora" is clarified as the result of a psychological projection of internal stimuli onto the external world. ${ }^{440}$

However, Freud concludes that if the ability to process external or internal stimuli is compromised, an unchecked invasion of stimuli may damage the organism. ${ }^{441}$ This conclusion relates to the idea, presented in numerous texts by Novalis, Schopenhauer and Nietzsche, that disease is triggered by an excessive influx of stimuli. Novalis uses metaphor to describe this pathological event: "Indirekte [...] Asthenie [...] entsteht durch Blendung

\footnotetext{
${ }^{434}$ Nietzsche KSA 6, p. 267.

${ }^{435}$ Freud XIII, p. 27.

${ }^{436}$ Ibid., pp. 28, 35.

${ }^{437}$ Novalis 2, p. 561.

${ }^{438}$ Freud XIII, p. 29. Thomas Mann's knowledge of Freud's term is suggested in chapter seven of Der Zauberberg by the portrayal of telekinesis as "biopsychische Projektionen unterbewußter Komplexe ins Objektive" (1013).

${ }^{439}$ See above; see also 3.2, p. 75.

${ }^{440}$ Similarly, Castorp's shock at the prevalence of death and disease at the sanatorium (see 2.1, pp. 21-23) is translated into physical symptoms (cold feet and a hot face). These take a turn for the worse when he learns about the demise of his room's previous occupant: “"[M]ich friert! Mich friert abscheulich, nämlich am Körper, denn im Gesicht bin ich auffallend echauffiert, - da, fühle doch mal, wie ich brenne!"” (25)

${ }^{441}$ Freud XIII, pp. 31, 36.
} 
- Übermäßiges Licht” ${ }^{442}$ In Jenseits von Gut und Böse, Nietzsche links stimuli to neurosis, which he believes is caused by an excess of "Empfindungen, Kenntnisse, Erfahrungen". 443 Freud similarly believes that neurosis can be caused by a person's inability to cope with "[einer] Anhäufung von Erregung". ${ }^{44}$ Freud develops this idea in his theory of traumatic neurosis, according to which, neurotic symptoms following psychological pain (stimulus) are in fact caused by the individual's repression of the event. ${ }^{445}$ This theory demonstrates Freud's debt to the philosophy of Schopenhauer, who writes in reference to the mythological Greek river of forgetting: "[D]er [...] Wahnsinn ist der Lethe unerträglicher Leiden" ${ }^{446}$ In clear anticipation of Freud's later hypothesis, Schopenhauer thus believes insanity to be a disease of memory. ${ }^{447}$

The network of intertexts outlined above enriches the interpretation of Castorp's encounter with Anton Karlowitsch Ferge in the chapter section "Totentanz". Ferge is bedbound at the time of Castorp's visit, recovering from an operation to deactivate (and thereby rest) his diseased lung by injecting air into the pleural cavity. ${ }^{448}$ This pneumothorax operation was conducted under local anaesthetic, and Ferge was fully conscious and aware during most of the procedure. He is thus able to recount his experience in gruesome detail, and does so, starting with the feeling of his body being opened up by the surgeon (Director Behrens): "Es ist so, als ob ich gedrückt und gequetscht würde, das ist das Fleisch, das geöffnet und mit Klammern zurückgezwängt wird" (470). Ferge's horrific account concludes with the sensation of Behrens touching the membrane surrounding Ferge's lungs (the pleura) with a blunt instrument: "[D]as Abgetastetwerden des Rippenfells, meine Herren, das ist ja, als ob man auf die allerinfamste, übertriebenste und unmenschlichste

\footnotetext{
${ }^{442}$ Novalis 2, p. 620.

${ }^{443}$ Nietzsche KSA 2, p. 204; see also ibid., pp. 232-33.

${ }^{444}$ Freud I, p. 317.

${ }^{445}$ Freud XIII, pp. 29, 31; Freud XI, p. 396.

${ }^{446}$ Schopenhauer II, p. 516.

${ }^{447}$ Schopenhauer I, pp. 274-76; see also Schopenhauer II, pp. 514-19; Schopenhauer IV, p. 281. My discussion of the relationship between Freud and Schopenhauer's theories is indebted to Marcel Zentner's research on repression and memory in the work of Freud and Schopenhauer (M. Zentner. Die Flucht ins Vergessen: Die Anfänge der Psychoanalyse Freuds bei Schopenhauer. Darmstadt: Wissenschaftliche Buchgesellschaft, 1995, p. 49).

${ }^{448}$ The pleural cavity is the space filled with fluid between the two membranes around the lungs.
} 
Weise gekitzelt würde" (471). The astute reader will recognise this tickling metaphor from the chapter section "Humaniora", where it was used to describe the skin's sensitivity to stimuli. ${ }^{449}$ The use of this motif in the context of Ferge's operation clearly indicates the significance of stimulus; and indeed, Ferge's operation was cancelled after this tickling sensation caused a potentially life-threatening "pleural shock" (vasomotor collapse) (46970). In fact, Ferge's pleural shock is best explained by the texts by Novalis, Schopenhauer, Nietzsche and Freud discussed in the previous paragraph. Accordingly, Ferge's operation, which exposed areas normally protected by outer layers of skin, fat and muscle, can be interpreted as a traumic invasion of his body by external stimuli.

In addition to the physical trauma of his pleural shock, Ferge found his operative experience psychologically traumatic:

Entsetzlich, meine Herren, - nie hätte ich gedacht, daß so ein siebenmal scheußliches und hundsföttisch gemeines Gefühl auf Erden und abgesehen von der Hölle überhaupt vorkommt! Ich fiel in Ohnmacht, der Pleurachok warf sich mir auf den Geruchsinn, meine Herren, es roch über alle Maßen nach Schwefelwassserstoff, wie es in der Hölle riechen muß, und bei alldem hörte ich mich lachen, während ich abschnappte, aber nicht wie ein Mensch lacht, sondern das war die unanständigste und ekelhafteste Lache, die ich in meinem Leben je gehört habe [...]. (470-71)

Ferge's flight into unconsciousness is linked to Freud's and Schopenhauer's idea, outlined in the paragraph before last, that an individual can repress/lose their memory of a traumatic event in order to avoid feeling pain. Yet the interpretation of Ferge's experience as a psychological trauma is complicated by the fact that Ferge's operation takes place under local anaesthetic. This contradicts Freud's belief that, while penetration of stimuli into the unconscious is potentially traumatic, consciousness of stimuli helps protect the individual from damage. Freud describes the ability of consciousness to protect the individual against stimulus in the following passage from "Jenseits des Lustprinzips": "Das System Bw [Bewußtsein] wäre also durch die Besonderheit ausgezeichnet, daß der Erregungsvorgang

${ }^{449}$ See 3.1, p. 68. 
in ihm [...] gleichsam im Phänomen des Bewußtwerdens verpufft." ${ }^{450}$ By suggesting that Ferge's conscious state should have protected him against trauma, this text raises the possibility that Ferge fainted because the influx of stimuli was too great for his conscious mind to process. This interpretation concurs with further passages from "Jenseits des Lustprinzips", in which Freud describes how excessive stimuli can break through the individual's conscious defence mechanisms to make a traumatic impression on the unconscious. ${ }^{451}$

Although Ferge's experience has clearly traumatised him, he recounts his story more than once during Castorp's visit: “Oft und nicht anders als mit fahlem Grauen kam Anton Karlowitsch Ferge auf dies 'hundsföttische' Erlebnis zurück und ängstigte sich nicht wenig vor seiner Wiederholung." (471; see also 680) Ferge's terror seems incompatible with the desire to recount his experience, and this leads the reader to wonder what compels Ferge to relive such a psychologically traumatic event. The aim of Freudian psychoanalysis is to bring a patient's subconscious trauma to a conscious level where it can be resolved. ${ }^{452}$ This idea is anticipated in the second volume of Die Welt als Wille und Vorstellung, in which Schopenhauer maintains that mental health is dependent on the intellect's ability to assimilate traumatic events. ${ }^{453}$ These texts suggest that Ferge's compulsion to retell his story is an instinctual attempt to process his trauma by re-examining it consciously. However, this interpretation does not explain Ferge's emotional reaction every time he mentions his operation. An explanation for both Ferge's drive to relate his story and his terror at the memory can be found in "Jenseits des Lustprinzips". Here, Freud develops his theory of trauma in the concept of the Wiederholungszwang: the painful compulsion to relive traumatic experiences. ${ }^{454}$ Freud argues that this urge serves a cathartic purpose by allowing the victim to add the (conscious) fear that was lacking, as the trauma occurred,

\footnotetext{
${ }^{450}$ Freud XIII, p. 25. Freud's conviction that consciousness protects the organism against stimuli reiterates the idea discussed earlier in this subchapter that a secondary process is crucial to the organism's health (see 3.3, pp. 80-81).

${ }^{451}$ Freud XIII, p. 29; see also ibid., pp. 31, 36.

452 Ibid., p. 16.

${ }^{453}$ Schopenhauer II, p. 516; see also M. Zentner, op. cit., p. 67.

${ }^{454}$ Freud XIII, p. 17.
} 
due to shock. This fear ("Angstbereitschaft") ${ }^{455}$ would have protected the individual by preparing him or her for the imminent attack. ${ }^{456}$ Freud's discussion of the Wiederholungszwang suggests the following interpretation of Ferge's compulsion in Der Zauberberg: Ferge's shock at the sensation of Director Behrens touching his insides was so great that he was not able to feel fear, and his compulsive repetition of his experience and accompanying terror are consequent attempts to process his trauma. ${ }^{457}$

The discussion of the Wiederholungszwang in "Jenseits des Lustprinzips" is predated by Freud's analysis of Wilhelm Jensen's novel Gradiva. In this study, Freud interprets the hero's urge to travel to Pompeii (the buried city is a metaphor for his repressed drives) as a form of the Wiederkehr des Verdrängten ${ }^{458}$ (return of the repressed), a concept closely related to the Wiederholungszwang. In Pompeii, the hero of Gradiva is reunited with his childhood sweetheart, and after being subjected to a form of psychoanalytic therapy, he realises (i.e. makes conscious) his love for her. ${ }^{459}$ Particular parallels between Gradiva and Der Zauberberg can be found a few pages before Castorp's visit to Ferge, where Frau Gerngroß blames herself for her daughter's illness, believing that her own youthful bout of tuberculosis has somehow resurfaced in her daughter. Using archaeological metaphors similar to those in Gradiva, Frau Gerngroß describes this return of her disease in her daughter's body as "das Begrabene und Vergessene wieder zum Vorschein gekommen" (458).

The phenomena of the Wiederkehr des Verdrängten and of the Wiederholungszwang are also illustrated in Der Zauberberg by Hans Castorp's infatuation with Madame Chauchat, which reiterates Castorp's youthful obsession with his schoolmate Pribislav Hippe. Unlike Ferge's compulsion, Castorp's drive to re-enact the past is not the result of external stimuli breaking through physical and psychological barriers, but rather of internal stimuli penetrating his unconscious. This idea relates metatextually to Freud's belief that an inability to process primal drives as they enter the unconscious can both cause

\footnotetext{
455 Ibid., p. 31.

456 Ibid., pp. 31-32.

${ }^{457}$ Ibid., p. 31.

${ }^{458}$ Freud VII, p. 60.

${ }^{459}$ Ibid., pp. 46-47, 52, 65.
} 
trauma and leave "[eine] Dauerspur[] der Erregung". ${ }^{460}$ Freud's theory suggests that Castorp's feelings for Hippe might have become embedded in his unconscious; however, it also raises the question of why Castorp's psyche failed to process his feelings. One possible answer is that Castorp intentionally repressed his love for Hippe. This repression is depicted metaphorically in a passage from the chapter section "Hippe", in which the young Castorp borrows a pencil from Hippe, very carefully sharpens it, and stores the shavings “in einer inneren Schublade seines Pultes" (188). ${ }^{461}$ This inner drawer symbolises Castorp's unconscious: after hiding the shavings, Castorp returns the pencil, never speaks to Hippe again, and forgets about both Hippe and the pencil shavings until years later at the sanatorium. ${ }^{462}$ Although these actions confirm that Castorp represses his feelings for Hippe, the text of Der Zauberberg does not explain why. The missing motive can be found by analysing the work of Schopenhauer and Freud, who both believe love to be a psychological mechanism steered by sexual drives. ${ }^{463}$ Understandably, the reader may find it difficult to accept this view in the context of a childhood crush; however, the brief exchange between Castorp and Hippe is portrayed in unmistakeably sexual terms. Castorp's request followed by receipt of the pencil, for example, is described as "intime[r] Verkehr mit Hippe" (188), after which Castorp feels "abgestumpft und gewöhnt" (188). In addition, the pencil itself has a suggestive retractable mechanism: "[Es war] ein versilbertes Crayon mit einem Ring, den man aufwärts schieben mußte, damit der rot gefärbte Stift aus der Metallhülse wachse" (188). These sexual metaphors suggest that Castorp's repression of his love follows a reluctance to admit culturally taboo, homosexual feelings. This in turn aligns the adult

\footnotetext{
${ }^{460}$ Freud XIII, p. 24; see also ibid., p. 36.

461 As both Hans Wysling and James Bade note, this passage refers to Mann's own experience of storing pencil shavings from a beloved (Hippe's prototype, Williram Timpe) (H. Wysling. “Der Zauberberg - als Zauberberg", op. cit., p. 49; J. Bade. "Ein unveröffentlichter Brief Thomas Manns an Otto Grautoff", in Jahrbuch der Deutschen Schillergeschellschaft, vol. 39. Stuttgart: A. Kröner Verlag, 1995, pp. 80-86, here, pp. 82-83.

462 C. A. Noble comes to a similar conclusion in Krankheit, Verbrechen und künstlerisches Schaffen bei Thomas Mann (op. cit., pp. 139-40).

${ }^{463}$ Schopenhauer II, p. 681; Freud XIII, p. 98. The theme of Eros will be discussed in depth in chapters five and six of the thesis.
} 
Castorp's infatuation with Madame Chauchat with Freud's belief that the Wiederholungszwang can be caused by the repression of childhood sexuality. ${ }^{464}$

Castorp's repressed desire for Hippe gradually surfaces in Der Zauberberg during chapters three and four, triggered in the chapter section "Natürlich, ein Frauenzimmer!" by the sight of Madame Chauchat's oddly familiar Slavic cheekbones and slanted eyes (119; see also 130,133). This process continues when Castorp's repressed memories temporarily surface at the end of the chapter section "Satana macht ehrrührige Vorschläge". Here, Castorp dreams that he and Madame Chauchat are in the courtyard of his old school, a dream that re-enacts the symbolic pencil exchange between himself and Hippe, and that enables the sleeping Castorp to realise whom Chauchat has reminded him of (140). ${ }^{465}$ Following Freud's conviction that dreams can fulfil a neurotic compulsion to re-enact trauma, ${ }^{466}$ Castorp's realisation while dreaming underscores the interpretation of Chauchat as a manifestation of Castorp's Wiederholungszwang. Moreover, when Castorp forces himself awake in order to capture this knowledge consciously, he brings his repressed memory to a conscious level, in clear correspondance to the psychoanalytic unearthing of repressed events.

Castorp's repressed memory surfaces again while alone in the forest in the chapter section "Hippe". After walking for some time, Castorp comes across a secluded clearing carpeted with blue flowers, through which a mountain stream cascades over rocks on its way down to the valley. The presence of blue flowers in the clearing recalls die blaue Blume (the blue flower) in Novalis's Heinrich von Ofterdingen, ${ }^{467}$ a symbol of Romantic yearning that is reconfigured in Der Zauberberg as homosexual desire. Castorp's pleasure at the beautiful nature around him and at the sound of rushing water, for example, is interrupted by a sudden nosebleed, and after losing a large amount of blood and sinking into a state of "herabgesetzter Lebenstätigkeit" (183), Castorp has a vision that sets him back in the schoolyard with Hippe. The juxtaposition in this scene of physical weakness and cerebral

\footnotetext{
464 Freud XIII, p. 19.

465 Castorp's dreams in Der Zauberberg affirm Freud's conviction that the dream modifies real events to satisfy the wishes of the dreamer (see Freud I, pp. 643-700).

${ }^{466}$ Freud XIII, p. 21.

${ }^{467}$ Novalis 1, p. 195.
} 
activity clearly relates to Nietzsche's concept of decadence, in which life force (symbolised by the body) decreases in proportion to an increase in mental activity. ${ }^{468}$ Furthermore, this scene appears to pay direct homage to Nietzsche's experience while writing Morgenröte of “jene[r] [...] Vergeistigung, die mit einer extremen Armuth an Blut und Muskel beinahe bedingt ist" ${ }^{469}$ However, the forest scene in Der Zauberberg modifies Nietzsche's concept of the mind dominating a weak body in the idea that the entire organism (intellect included) is under the control of primal drives. This modification in effect combines Nietzsche's concept of decadence with the conviction shared by Nietzsche, Schopenhauer and Freud that drives determine human activity. ${ }^{470}$

The return of Castorp's repressed memory/desire occurs, as we have seen, as he is dreaming, and as he lies in a semiconscious state after having lost a quantity of blood. These circumstances suggest that unconsciousness and semiconsciousness are conducive to the expression of drives, an idea that concurs metatextually with the view of both Freud and Nietzsche that drives surface in dreams, ${ }^{471}$ as well as with Schopenhauer's related belief that dreams are initiated by "[einer] Erregung [...] aus dem Innern des Organismus". 472 Castorp's experience also gains heuristic depth from the reader's knowledge of Nietzsche's figure of Dionysus in Die Geburt der Tragödie. The instinctual Dionysus symbolises both the unconscious ${ }^{473}$ and intoxication ("Rausch"), ${ }^{474}$ and these characteristics are reflected in

\footnotetext{
${ }^{468}$ Nietzsche KSA 1, p. 116; Nietzsche KSA 5, pp. 339-412; Nietzsche KSA 6, pp. 13-53, 264-65, 372. Thomas Mann similarly describes decadence as follows: "[D]ie Psychologie ermüdenden Lebens, die seelischen Verfeinerungen und ästhetischen Verklärungen [...], welche den biologischen Niedergang begleiten" (Mann 19.1, p. 356).

${ }^{469}$ Nietzsche KSA 6, p. 265.

${ }^{470}$ See 3.2, p. 77.

${ }^{471}$ Freud II, p. 126; Nietzsche KSA 3, p. 112. This idea is linked to Freud's theory, discussed towards the beginning of this subchapter, that inner drives have direct access to the unconscious (see 3.3, p. 81).

${ }^{472}$ Schopenhauer IV, p. 283.

473 Nietzsche KSA 1, pp. 25-30; see also Nietzsche KSA 6, p. 310. The following poem from Richard Wagner's Tristan und Isolde quoted by Nietzsche in Die Geburt der Tragödie establishes the relation of Dionysus to the unconscious: "In des Wonnemeeres / wogendem Schwall, / in der Duft-Wellen / tönendem Schall, / in des Weltathems / wehendem All - / ertrinken - versinken - / unbewusst - höchste Lust!" (Nietzsche KSA 1, p. 141) Dionysus thus once again contrasts Apollo, whose embodiment of form and rationality suggests consciousness.

474 The motif of "Rauschen" is used repeatedly during the forest scene (182-83), in reflection of its prevalence in Romantic fairy tales. Furthermore, the forest scene in "Hippe" is described using (Romantic) lyrical syntax,
} 
"Hippe" by a rush of white noise in Castorp's ears as he lies half-conscious on a bench in the forest clearing (183). Nietzsche states that the Dionysian state of intoxicated semiconsciousness allows the dissolution of time and space, ${ }^{475}$ an idea that clearly follows Schopenhauer's belief that dream-states allow independence from "den Beschränkungen, welche Raum, Zeit und Kausalität herbeiführen". ${ }^{476}$ Similarly, Castorp's intoxicated, semiconscious state leads to an impression of "[der] Aufhebung des Raumes und der Zeit" (183). This feeling is subsequently linked to Castorp's memory of Hippe, i.e. to Castorp's unconscious drives, and thus also reflects Freud's following claim from "Jenseits des Lustprinzips": “[D]ie unbewußten Seelenvorgänge [sind] an sich 'zeitlos"”.477 Schopenhauer similarly connects the perception of space and time as illusory concepts to recognition of the Will. ${ }^{478}$ These texts discussed above indicate that Castorp's semiconsciousness, the white noise in his ears, and his impression of temporal and spatial dissolution, are all significant to the recovery of his repressed desire for Hippe.

In Der Zauberberg, Freud's concepts of the Wiederkehr des Verdrängten and the Wiederholungszwang are further linked to disease. Director Behrens identifies two tubercular patches within Castorp's lung: "[E]ine[] frische[] Stelle” (277) that corresponds to Castorp's present infatuation with Madame Chauchat, and "eine Dämpfung" (276) from an earlier bout of tuberculosis representative of Castorp's love for Hippe. The equation of tuberculosis with desire is explored further in Der Zauberberg when Castorp finds a causal connection between the development of his tuberculosis at the sanatorium and his vision of Hippe in the forest: "[Das Erlebnis im Wald hat] auf seinen Körper revolutionierend gewirkt und [hat] die still vorhandene Krankheit zum Ausbruch gebracht” (285). This conclusion relates to Freud's idea that a Wiederholungszwang can be activated by

\footnotetext{
as in the following example: "Aber kaum hatte er sichs bequem gemacht, als ein Nasenbluten ihn so plötzlich befiel, daß er seinen Anzug nicht ganz vor Verunreinigung schützen konnte.” (182)

${ }^{475}$ Nietzsche KSA 1, p. 133.

476 Schopenhauer IV, p. 319.

477 Freud XIII, p. 28. The following statement by Novalis is of interest considering the metaphorical equivalence of the unconscious and the night: "[Z] eitlos und raumlos ist die Nacht Herrschaft" (Novalis 1, p. 132).

${ }^{478}$ Schopenhauer I, pp. 259-60.
} 
psychoanalysis. ${ }^{479}$ Castorp's vision while lying prostrate on a bench (a Freudian couch!) can consequently be interpreted as the trigger of his compulsion, in the chapter section "Walpurgisnacht", to re-enact the schoolyard scene with Hippe by borrowing a pencil from Chauchat (504).

The interpretation of Chauchat as a repetition of Hippe is challenged by Castorp's thoughts after his vision: "Darum also interessiere ich mich so für sie? Oder vielleicht auch: habe ich mich darum so für ihn interessiert?" (189) This passage suggests that the relationship between Chauchat and Hippe transcends the concept of linear time, an idea that confirms the link between Chauchat/Hippe and Freud's circular concepts of the Wiederkehr des Verdrängten and the Wiederholungszwang. Moreover, the suggestion in Castorp's musings quoted above that his interest in Hippe has defined his interest in Chauchat concurs with Nietzsche's "Logik des Traumes": "[D]er Traum [...] ist das Suchen und Vorstellen der Ursachen für jene erregten Empfindungen, das heisst die vermeintlichen Ursachen". ${ }^{480}$ Yet Castorp's reversal of the logical order of cause and effect is a small disturbance in the text's strong, consistent argument that his infatuation with Chauchat has been defined by his experience with Hippe. An explanation for both causalities is given by Schopenhauer's theory that individuals are multiple representations of the one Will. ${ }^{481}$ Similarly, Novalis declares: "Was man liebt, findet man überall, und sieht überall Ähnlichkeiten”,;82 “[g]ewinnt [...] nicht das Allgemeine durch individuelle, das Individuelle durch allgemeine Beziehungen?"483 Novalis's mythologisation of the individual is given a pathological slant in Gradiva, in which Freud notes a phenomenon of psychological substitution when two individuals become one in the eyes of the subject. ${ }^{484}$

\footnotetext{
${ }^{479}$ Freud XIII, pp. 16-18.

${ }^{480}$ Nietzsche KSA 2, pp. 32-33.

${ }^{481}$ Schopenhauer II, p. 610. Chauchat and Hippe's shared identity is also reflected in the following passage from Die Welt als Wille und Vorstellung: "[D]ie Katze, welche eben jetzt auf dem Hof spielt, sei noch dieselbe, welche dort vor dreihundert Jahren die nämliche Sprünge und Schliche gemacht hat” (ibid., p. 616).

482 Novalis 2, p. 485.

${ }^{483}$ Ibid., p. 486. Thomas Mann comments on Novalis's view of the universal within the individual in "Von deutscher Republik" (Mann 15.1, pp. 518, 540).

${ }^{484}$ Freud VII, p. 58.
} 
The temporal interrelation of Chauchat and Hippe is illuminated further by the following aphorism from Nietzsche's Menschliches, Allzumenschliches:

\begin{abstract}
Alle stärkeren Stimmungen bringen ein Miterklingen verwandter Empfindungen und Stimmungen mit sich; sie wühlen gleichsam das Gedächtniss auf. Es erinnert sich bei ihnen Etwas in uns und wird sich ähnlicher Zustände und deren Herkunft bewusst. So bilden sich angewöhnte rasche Verbindungen von Gefühlen und Gedanken, welche zuletzt, wenn sie blitzschnell hinter einander erfolgen, nicht einmal mehr als Complexe, sondern als Einheiten empfunden werden. ${ }^{485}$
\end{abstract}

This passage and the texts by Novalis, Schopenhauer and Freud quoted above indicate the insufficiency of temporal and spatial laws to explain physical and psychological phenomena. Castorp's query quoted earlier consequently appears as an extremely subtle observation about the nature of perception that replaces the concept of linear time with a matrix of associations.

\title{
3.4 Stimuli, life and disease
}

In the previous subchapter, I demonstrated that the text of Der Zauberberg portrays the cause of disease as an excess of stimuli. In the chapter section "Forschungen", this is modified in the idea that disease itself is a form of stimulus. After a hearty dinner of roast beef in the sanatorium restaurant, Castorp buttons himself into his fur sleeping bag on his deckchair, a glass of milk laced with cognac by his side, and settles down to read about anatomy, physiology and biology. His research culminates in a study of pathological anatomy that describes infection in terms of " $\mathrm{d}[\mathrm{es}]$ Eindringen[s] fremdartiger Zellen in einen Organismus" (431), “de[s] Kitzel[s] einer unbekannten Infiltration” (433), and bacterial "Reiz" of the organism's cells (432). The words "tickle", and "irritation" were used in the chapter section "Humaniora" and "Totentanz" to describe the effect of stimuli on the organism $(399,400-01,471){ }^{486}$ their repetition in the context of disease indicates that bacteria also stimulate. The consequent inference within the primary text that stimuli are allied to both life and disease relates to Freud's idea that the repression of internal

\footnotetext{
${ }^{485}$ Nietzsche KSA 2, p. 35.

${ }^{486}$ See 3.1 , p. $68 ; 3.3$, pp. 82-83.
} 
stimuli (unconscious drives designed to ensure the well-being of the individual) can cause neurosis. ${ }^{487}$ More specifically, the ambiguous nature of stimuli in "Forschungen" also corresponds to Novalis's following note: “[John Browns] Eintheilung [von Reizbarkeit und Reiz] trift beydes Leben und Krankheit". ${ }^{488}$

The description in Castorp's textbook of the effect of bacteria/pathological stimuli transcends the page when Castorp sinks into a half slumber and dreams of Madame Chauchat. "[V]ergehend vor Lust und Grauen" (434), Castorp's response at the approach of this vision replicates the organism's ambivalent reception of disease described in his textbook (432). Moreover, Chauchat's approach is clearly sinister: "Sie neigte sich ihm, neigte sich zu ihm, über ihn" (434). The description of her skin as "körnig" (434) a page after the textbook's portrayal of diseased flesh filled with bacterial "Kernen" (432) only deepens the reader's suspicion that Chauchat is a personification of bacteria intent on invading Castorp's body. The moment of infection takes the form of a kiss reminiscent of the "Parasit" (432) in Castorp's book docking onto the host organism:

Heiße Zartheit umschlang seinen [Castorps] Hals, und während er, vergehend vor Lust und Grauen, seine Hände an ihre äußeren Oberarme legte, dorthin, wo die den Triceps überspannende, körnige Haut von wonniger Kühle war, fühlte er auf seinen Lippen die feuchte Ansaugung ihres Kusses. (434)

The importance of touch between two physical bodies in this metaphor of infection corresponds selectively to the following fragment by Novalis: "Leben entsteht, wie Kranckheit, aus einer Stockung - Begränzung - Berührung." ${ }^{489}$ Not only does this text inform the tactile depiction of infection in "Forschungen", but it also explains the relationship of stimuli to both disease and life by indicating essential similarities between life and disease. This interrelation of life and pathology is confirmed in "Forschungen" by the description of Madame Chauchat's body, itself saturated with lymphatic tuberculosis, as “das Bild des Lebens" (433).

The equivalence of life and disease is also reflected in Der Zauberberg in the

\footnotetext{
${ }^{487}$ Freud X, p. 335; see also Freud XIII, p. 56.

${ }^{488}$ Novalis 3, p. 453.

${ }^{489}$ Novalis 2, p. 561.
} 
portrayal of substances that both support and destroy life, an idea first introduced using the example of protein in the chapter section "Humaniora". Here, Behrens describes metabolic processes in terms of "[eines] Sauerstoffbrand[s] des Zelleneiweiß" (404), thereby indicating that protein is fundamental to life. However, a few pages later in the chapter section "Forschungen", bacterial toxins are also identified as protein compounds (432). This ambiguity is reviewed by Mynheer Peeperkorn, who notes that science is unable to explain the poisonous effects of snake venom (a protein compound) (873-74), and who subsequently observes that all substances have the potential to enhance or extinguish life. This observation, quoted below, is allied to the ambiguous relation of stimuli to both life and disease:

[M]it den Stoffen stehe es so, daß alle Leben und Tod auf einmal bärgen: alle seien Ptisanen und Gifte zugleich. Heilmittelkunde und Toxikologie seien ein und dasselbe, an den Giften genese man, und was für des Lebens Träger gelte, töte unter Umständen mit einem einzigen Krampfschlage in Sekundenfrist. (874)

Peeperkorn's reference to chemical compounds in this passage echoes texts by Novalis that explore the relationship between medicine and poison. The assertion that medicine and toxicology are one and the same, for example, selectively parallels the following fragment from Novalis’s “Medizinische Bemerkungen” (1799-1800): "Über die Wirckungs Art der Arzneymittel - Eisenkalk ist heilsam und Quecksilberkalk tödtet!!!"490 Peeperkorn's subsequent claim that poisons promote healing corresponds referentially and selectively to the "Stärkungssystem" proposed by Novalis in the "Teplitzer Fragmente" (1798), in which “die bisherigen Gifte und reitzenden Substanzen eine große Rolle spielen". ${ }^{491}$ Affirmation of this fragment can also be found in Peeperkorn's earlier description of quinine as "ein echter Labetrank, ein herrliches Stärkungs-, Erweckungs- und Belebungsmittel” (873). An ironic connection between this Brownian use of stimulants to treat disease and the primary text is made via Peeperkorn's self-medication with coffee, wine and schnapps, to which he ascribes antipyretic properties (838-39). However, Peeperkorn's enlarged spleen (839)

\footnotetext{
${ }^{490}$ Novalis 3, p. 616.

${ }^{491}$ Novalis 2, p. 602.
} 
suggests that his life-supporting "medication" is actually destroying his health, in an inversion of the relationship between medicine and poison that wittily illustrates how Thomas Mann complements the theoretical discussion of concepts in Der Zauberberg with individual human examples.

The relationship between life and disease is present from the moment of birth. The determining power of heredity discussed in subchapter 3.2 of this thesis ${ }^{492}$ is linked in the chapter section “Totentanz" to disease via Frau Gerngroß's guilt at contributing to her daughter's illness (458). ${ }^{493}$ Frau Gerngroß's penitent (“zerknirscht" [458]) expression in this scene is linked metatextually to Schopenhauer's following observation: “[D]ie Wurzel der Schuld [liegt] in unserer essentia et existentia [Wesenheit und Dasein] [...]. Demnach ist eigentlich unsere einzige wahre Sünde die Erbsünde". ${ }^{494}$ This text suggests a hereditary aspect to Frau Gerngroß's guilt, yet the relationship between this heredity and disease is first illuminated by the reader's knowledge of texts by Novalis, Nietzsche and Freud. Novalis, for example, states: "Alle wahre Kranckheiten sind erblich". 495 Nietzsche similarly describes the predisposition of an individual to disease according to "hereditäre[r] Erschöpfung", ${ }^{496}$ and Freud notes the existence of "hereditäre[r] Krankheitsneigungen" ${ }^{497}$ Frau Gerngroß's self-reproach blends the message of these last texts with Schopenhauer's view quoted above by expressing the idea that humans are guilty of passing disease on to the following generations.

Novalis and Freud both believe that pathological inheritance expresses itself as individual constitution. ${ }^{498}$ This idea is explored in Der Zauberberg by Castorp, who ascribes his own weakness to the disease "[die] ein Bißchen in [sein] er Familie liegt” (282).

\footnotetext{
${ }^{492}$ See 3.2, pp. 78-79.

${ }^{493}$ See also 3.3 , p. 85 .

${ }^{494}$ Schopenhauer II, p. 773. The message of this text is further reproduced in Der Zauberberg by Naphta, who similarly believes that guilt is within the essence of being: "Der Verbrecher sei von seiner Schuld durchdrungen wie von sich selbst. Denn er sei, wie er sei, und könne und wolle nicht anders sein, und dies eben sei die Schuld." (695)

495 Novalis 3, p. 615.

${ }^{496}$ Nietzsche KSA 6, p. 90.

${ }^{497}$ Freud I, p. 501; see also Freud XIII, p. 54.

${ }^{498}$ Novalis 2, p. 573; Freud VIII, p. 210.
} 
Castorp's affinity with disease is interpreted positively by Director Behrens as "Talent [...] zum Kranksein” (74), i.e. as pathological potential. Indeed, soon after his arrival, Castorp develops a flushed face $(27,64)$, then catarrh and fever $(252,259)$, and he is finally diagnosed with tuberculosis in the chapter section "Das Thermometer" (277). The implied progression of Castorp's diseases relates to the following fragment by Novalis: "Häufige indirecte Kranckheit geht am Ende in direkte über". ${ }^{499}$ The continuation of this fragment explains health and disease as part of a cyclical process: "Indirecte Ges[undheit] folgt der dir[ecten] Kranckheit so gewiß, wie indirecte Kr[anckheit] der Gesundheit."500 This interrelation of disease and health is reflected in Castorp's claim, in the chapter section "Ewigkeitssuppe und plötzliche Klarheit", that an outbreak of latent disease is necessary “wenn Heilung eintreten soll” (297). ${ }^{501}$ Castorp's claim also clearly relates to the Freudian psychoanalytic goal of bringing repressed psychological trauma to the surface, ${ }^{502}$ an idea anticipated in the link made by Nietzsche between an outburst of Dionysian insanity (synonymous with drive expression) and "überströmender Gesundheit". 503 This last text with its emphasis on insanity selectively informs Naphta's following statement in the chapter section "Operationes spirituales": "Es habe Menschen gegeben, die bewußt und willentlich in Krankheit und Wahnsinn gegangen seien, um der Menschheit Erkenntnisse zu gewinnen, die zur Gesundheit würden, nachdem sie durch Wahnsinn errungen worden” (701). ${ }^{504}$ The causal relationship between insanity, disease and health in this passage underscores the link between life and disease in Der Zauberberg. ${ }^{505}$

The interrelation of life and disease is further addressed in Der Zauberberg in the

\footnotetext{
499 Novalis 3, p. 81. Freud also notes the contemporary belief that disease can lie dormant until later development (Freud XIII, p. 54).

500 Novalis 3 , p. 81.

501 The sanatorium environment is conducive to the development of disease: Behrens observes that mountain air "bringt die latente Krankheit zum Ausbruch" (277). This explains Castorp's second bout of tuberculosis at the sanatorium (276) (see 3.3, p. 89).

502 See 3.3 , p. 84 .

${ }^{503}$ Nietzsche KSA 1, p. 16.

504 Further parallels to Nietzsche's Dionysian drives appear in Naphta's comment on pathological enhancement in the chapter section "Als Soldat und brav": "Der Weg der Mysterien [...] [führte] durch das Reich der Verwesung, und der Lehrling, der Neophyt, ist die [...] nach Erweckung zu dämonischer Erlebnisfähigkeit verlangende Jugend" (771).

505 See above, pp. 91-92.
} 
chapter section "Humaniora", in which Director Behrens explains that both life and decay produce warmth as a product of oxidation (404). This idea is subsequently developed in "Forschungen" in the portrayal of life as a state of fever that harbours processes of renewal and decay:

Was war also das Leben? Es war Wärme, das Wärmeprodukt formerhaltender Bestandlosigkeit, ein Fieber der Materie, von welchem der Prozeß unaufhörlicher Zersetzung und Wiederherstellung unhaltbar verwickelt, unhaltbar kunstreich aufgebauter Eiweißmolekel begleitet war. Es war das Sein des eigentlich Nichtsein-Könnenden, des nur in diesem verschränkten und fiebrigen Prozeß von Zerfall und Erneuerung mit süß-schmerzlich-genauer Not auf dem Punkt des Seins Balancierenden. $(418)^{506}$

The idea expressed in this passage that both renewal and decay are inherent to life appears at first glance to exist in dialogical tension with the following fragment by Novalis: "Alles Leben ist ein überschwänglicher Erneuerungsproceß, der nur von d[er] Seite den Schein eines Vernichtungsproceßes hat." ${ }^{507}$ However, the context of this fragment is integral to its interpretation. The ensuing sentence describes life using the analogy of a flame (which consumes its source), an analogy that was used in the previous fragment to illustrate a process of self-overcoming, i.e. an act of simultaneous destruction and creation. ${ }^{508}$ This contextual meaning allows Novalis's statement quoted above to be interpreted as a celebration of renewal made possible by destruction. It is interesting to note that Nietzsche also uses a flame analogy to depict a process of dissolution and creation in Also sprach Zarathustra: "[I]ch trinke die Flammen in mich zurück, die aus mir brechen". 509 The destruction and renewal within life portrayed in the chapter sections "Humaniora" and "Forschungen" also relate to the first volume of Schopenhauer's Die Welt als Wille und Vorstellung, in which Schopenhauer interprets the consumption of other life forms as the Will feeding on itself, i.e. as life nourishing itself by means of its own destruction. ${ }^{510}$

\footnotetext{
506 This idea relates to the concept of death within life discussed in subchapter 2.2, pp. 31-32.

${ }^{507}$ Novalis 2, p. 556.

508 Ibid.

${ }^{509}$ Nietzsche KSA 4, p. 136; see also Nietzsche KSA 6, p. 346.

${ }^{510}$ Schopenhauer I, p. 227.
} 
The message that destruction is inherent to the process of renewal is explored further in Der Zauberberg in the portrayal of disease as stimulating. In the chapter section "Operationes spirituales", for example, Castorp considers that disease might be "ein erhöhter Lebenszustand" (700). This idea metatextually recalls Novalis's belief that bouts of illness can be "Lehrjahre der Lebenskunst", 511 as well as to Nietzsche's related view of disease as "ein energisches Stimulans zum Leben, zum Mehr-leben". ${ }^{12}$ However, in "Forschungen", the enhancement of life (the organism's cells) following bacterial stimulus is shown to be temporary:

Hirsekorngroße Knötchen bildeten sich, zusammengesetzt aus schleimhautgewebeartigen Zellen, zwischen denen oder in denen die Bazillen nisteten und von welchen einige außerordentlich reich an Protoplasma, riesengroß und von vielen Kernen erfüllt waren. Diese Lustbarkeit aber führte gar bald zum Ruin, denn nun begannen die Kerne der Monstrezellen zu schrumpfen und zu zerfallen, ihr Protoplasma an Gerinnung zu Grunde zu gehen; [...] der Organismus stand in Hochtemperatur, mit wogenden Busen, sozusagen, taumelte er seiner Auflösung entgegen. (432)

The conclusion of this pathological sequence with the death of the organism reflects Novalis's death-affirming conception of diseases as "Trancendenzen" 513 that enable "die Erhebung [...] des Menschen zu Gott". 514

Nevertheless, Novalis subsequently proves the idea that disease leads to death to be compatible with the pathological enhancement of life:

Unsere Kranck[heiten] sind alle Phaenomene erhöhter Sens[ibilität], die in höhere Kräfte übergehn will. Wie der Mensch Gott werden wollte, sündigt er. $\mathrm{Kr}$ [ankheiten] der Pflanzen sind Animalisationen. Krank[heiten] d[er] Thiere Rationalisationen. Krankh[eiten] der Steine - Vegetationen [...]. Pflanzen sind gestorbene Steine. Thiere - gestorbene Pflanzen. etc. Theorie der Metempsychose. ${ }^{515}$

\footnotetext{
${ }^{511}$ Novalis 3, p. 686. Nietzsche describes disease similarly: "Kranksein ist lehrreich, wir zweifeln nicht daran, lehrreicher noch als Gesundsein" (Nietzsche KSA 5, p. 358).

512 Nietzsche KSA 6, p. 266; see also ibid., p. 22.

${ }^{513}$ Novalis 3, p. 662.

${ }^{514}$ Ibid., p. 440. See also the discussion of death as transcendent in subchapter 2.2, p. 33.

515 Novalis 3, pp. 662-63. Novalis's theory of reincarnation is also mentioned in subchapter 2.2, pp. 34-35.
} 
The role of disease within the cycle of life expressed in Novalis's text is appropriated in Der Zauberberg in the chapter section "Forschungen". Here, the creation of matter and subsequent creation of life are shown to be processes initiated by pathological stimulus:

Der anfänglichste Schritt zum Bösen, zur Lust und zum Tode war zweifellos da anzusetzen, wo, hervorgerufen durch den Kitzel einer unbekannten Infiltration, jene erste Dichtigkeitszunahme des Geistigen, jene pathologisch üppige Wucherung seines Gewebes sich vollzog, die, halb Vergnügen, halb Abwehr, die früheste Vorstufe des Substantiellen, den Übergang des Unstofflichen zum Stofflichen bildete. Das war der Sündenfall. Die zweite Urzeugung, die Geburt des Organischen aus dem Unorganischen, war nur noch eine schlimme Steigerung der Körperlichkeit zum Bewußtsein [...] - : nur noch ein Folgeschritt war das Leben auf dem Abenteuerpfade des unehrbar gewordenen Geistes, Schamwärmereflex der zur Fühlsamkeit geweckten Materie, die für den Erwecker aufnahmelustig gewesen war... (433)

Thus, in "Forschungen", the Christian belief that God created life is subverted in the idea that life was initiated by the bacterial infiltration of Geist (the animating breath of God). ${ }^{516}$ This corresponds selectively to Novalis's claim: "Leben ist eine Kranckheit des Geistes". 517 Accordingly, the text of Der Zauberberg takes up the challenge posed by the following statement in "Forschungen": "[Z]wischen Leben und unbelebter Natur [...] klaffte ein Abgrund, den die Forschung vergebens zu überbrücken strebte" (417). The answer reads: the tickle of Mind (Geist) by disease created matter, and life is merely the arbitrary consequence of this pathological event.

\subsection{The interrelation of life, mind and disease}

The tickle of Mind by infiltrating pathological stimuli discussed in the previous subchapter

\footnotetext{
${ }^{516}$ Here, I follow the definition of Geist from the Grimm brothers' dictionary (1854-1961). The section including words beginning with $\mathrm{G}$ was compiled in 1866, and provides fascinating insight into $18^{\text {th }}$-century and 19th-century etymology (http://woerterbuchnetz.de/DWB/; online resource accessed 19 December 2012).

${ }^{517}$ Novalis 3, p. 659. Thomas Mann acknowledges Novalis's idea in "Von deutscher Republik" (Mann 15.1, p. 556). Novalis's fragment also relates to the following passage from the chapter section "Veränderungen": "[D]ie Materie [ist] als Sündenfall des Geistes, als eine schlimme Reizwucherung desselben aufzufassen" (554).
} 
relates to fragments by Novalis that describe life's origin in terms of the penetration of Mind into matter: "Aller Anfang des Lebens muß antimechanisch - gewaltsamer Durchbruch - Opposition gegen den Mechanism seyn - Absolute Materie - primitives Element des Geistes $=$ Seele. ${ }^{~}{ }^{118}$ Novalis crystallises this idea in a subsequent fragment from 1798:

Leben ist vielleicht nichts anders, als das Resultat d[er] Vereinigung [von Seele und Körper] - die Action dieser Berührung. Wie das Licht bey dem Reiben des Stahls an den Stein, der Ton bey Berührung des Bogens und der Sayte, die Zuckung bey Schließung und Öffnung der galvanischen Kette erfolgt, so vielleicht das Leben bey Erweckung (Penetration) des organischen Stoffs. ${ }^{519}$

The imagery of penetration and breakthrough used by Novalis in these fragments is reiterated in "Jenseits des Lustprinzips" by Freud, who suggests that life was created from the inorganic "durch eine noch ganz unvorstellbare Krafteinwirkung". 520 The language of these texts clearly relates to the depiction of life's pathological stimulation in "Forschungen", although the latter pre-empts the penetration of matter by Mind described by Novalis with the penetration of Mind by pathological stimuli.

The passage from "Forschungen" discussed above also equates the creation of matter and organic life with original sin (“[d]as war der Sündenfall” [433]). This passage thus further recalls the work of Novalis, in particular the following excerpt from "Einige Sätze des Brownischen Syst[ems]" (1800): "Mit der Sensibilitaet und ihren Organen, den Nerven tritt Kranckheit in die Natur. Es ist damit Freyheit, Willkühr in die Natur gebracht und damit Sünde, Verstoß gegen den Willen der Natur, die Ursache alles Übels".521 Accordingly, life appears to be inherently sinful, an idea also presented in a subsequent fragment by Novalis: "Die Oxyd[ation] kommt vom Teufel". ${ }^{22}$ Mind, by contrast, is

\footnotetext{
${ }^{518}$ Novalis 2, p. 575. This follows John Brown's hypothesis that life is the result of stimuli penetrating matter (see T. Broman, op. cit., p. 143).

${ }^{519}$ Novalis 2, p. 643. For Novalis, the difference between "Geist" and "Seele" is one of commonality and individuality. Thus he writes: "[I]ch nenne Seele [...] das individuelle Princip" (Novalis 2, p. 551).

${ }^{520}$ Freud XIII, p. 40.

${ }^{521}$ Novalis 3, p. 657.

${ }^{522}$ Ibid., p. 659.
} 
affiliated with God: "Die todte Materie ist Phlogiston [...] Phlogiston = Geist". ${ }^{523}$ These intertexts suggest that Mind is judged dishonest in "Forschungen" because Mind's role in the creation of life negates its true affiliation with death.

The relationship between disease and Mind is further explored in "Forschungen". As I discussed in 3.4, the second half of this chapter section shows Castorp researching the nature of life far into the night. ${ }^{524}$ Castorp's reluctance to retire to bed is attributed by the narrator to a mixture of physical apathy and mental excitement:

Was ihn so lange draußen hielt [...] [war] hauptsächlich [...] Trägheit und Angeregtheit, beides zugleich und im Verein: nämlich die Trägheit und bewegungsfeindliche Müdigkeit seines Körpers und die beschäftigte Angeregtheit seines Geistes, der über gewissen neuen und fesselnden Studien, auf die der junge Mann sich eingelassen, nicht zur Ruhe kommen wollte. (411-12)

It is easy to interpret this passage as a portrayal of normal physical tiredness (it is past midnight) and intellectual stimulation. However, the combination of physical lethargy and mental excitement is subsequently associated with Castorp's diseased state: “[E]in Gefühl von Betäubung und Trunkenheit kam ihn an, und sein Kopf stand in Hitze" (412). These symptoms suggest that the combination of Castorp's exhausted body and busy mind is intrinsically diseased. Castorp's symptoms consequently relate to Nietzsche's definition of decadence manifest as decreased life energy and increased intellectual activity. ${ }^{525}$ This inverse relationship between Life and Mind anticipates Freud's following observation on biological development in "Jenseits des Lustprinzips": "Höherentwicklung in einem Punkte [wird] sehr häufig durch Rückbildung in einem anderen erkauft oder wettgemacht". ${ }^{526}$ Furthermore, Nietzsche's theory of decadence is clearly reflected in Freud's belief that psychological (i.e. mental) neuroses are linked to the cultural suppression of sexual (i.e. physical) activity. ${ }^{527}$

\footnotetext{
${ }^{523}$ Ibid.

${ }^{524}$ See 3.4, p. 91 .

${ }^{525}$ See 3.3, pp. 87-88.

${ }^{526}$ Freud XIII, p. 44.

${ }^{527}$ Ibid., p. 56; see also Freud X, p. 335.
} 
The causality intrinsic to the intertexts by Nietzsche and Freud discussed above is also present in Castorp's conclusion that his mental excitement is due to fever: "Mit der gesteigerten Wärmeerzeugung seines Körpers [...] hatte gewiß [seine] geistige Erregung und Rührigkeit zu tun" (412). ${ }^{528}$ This conviction that physical disease can influence mental activity corresponds referentially to the following statements by Nietzsche from Die fröhliche Wissenschaft and Jenseits von Gut und Böse: "Erst der grosse Schmerz ist der letzte Befreier des Geistes”; 529 “de[r] Leidende[] [ist] de[r] Auserwählte[] der Erkenntniss, de[r] 'Eingeweihte[]'".530 This link between disease and genius is modified in Der Zauberberg in passages that present the subject of death as intellectually stimulating. ${ }^{531}$ Naphta, for example, asserts that without death "weder Architektur noch Malerei noch Skulptur noch Musik noch Dichtkunst überhaupt [...] gäbe" (690). This claim selectively parallels Schopenhauer's following statement from Die Welt als Wille und Vorstellung: "Der Tod ist der eigentliche inspirirende Genius oder der Musaget der Philosophie". 532 Naphta's interrelation of Mind and death can also be traced to the Romantic antithesis between life (represented by the body) and the immortal soul. ${ }^{533}$ The equation of this soul with the intellect is established in the following fragment by Novalis: "[D]er gelehrte und der geistliche Stand [...] streiten um Eine Stelle". ${ }^{534}$ It appears that Mind is in fact a concept that embraces Geist, soul and intellect. ${ }^{535}$ Thus, an affiliation of Mind with death can also be inferred in the chapter section "Ewigkeitssuppe und plötzliche Klarheit" from

\footnotetext{
${ }^{528}$ In the chapter section "Vom Gottesstaat und von übler Erlösung", Castorp's ruminations are similarly enhanced by "einer durch lösliche Gifte erzeugten Steigerung des Körpers" (588).

${ }^{529}$ Nietzsche KSA 3, p. 350; also quoted in E. Bertram, op. cit., p. 158.

${ }^{530}$ Nietzsche KSA 5, p. 225.

${ }^{531}$ References to death as genial appear in the chapter section "Mynheer Peeperkorn (Des Weiteren)" on pages 901, 902 and 903. The concepts of death and disease are interchangeable, as the reference to " $\mathrm{d}[\mathrm{em}]$ geniale[n] Prinzip der Krankheit" in the same chapter section indicates (923).

${ }^{532}$ Schopenhauer II, p. 590. I owe the identification of this passage to Käte Hamburger (K. Hamburger, op. cit., p. 58). Naphta's reference to "Dichtkunst" is reiterated in the "Gedächtnisrede für Friedrich Huch", in which Thomas Mann quotes Schopenhauer's maxim and adds his own variation: "Es würde schwerlich gedichtet werden auf Erden, ohne den Tod" (Mann 14.1, p. 381).

${ }^{533}$ See 2.2 , p. 30 .

${ }^{534}$ Novalis 3, p. 515; also quoted in G. Brandes, op. cit., p. 247.

535 An essential similarity between the soul and the intellect is apparent from Novalis's association of the former with the body: "Die Seele ist die Monas, deren Äußerungen mannichfaltige Monaden sind - der Sinn, sit Venia Verbis, der die übrigen Sinne durch Centralpuncte activirt und vereinigt.” (Novalis 2, p. 582)
} 
Settembrini”s description of death as "[eine] geistige Macht” (304).

The intellectualising function of death and disease is also illustrated by the inner development of Castorp, "[e]in einfacher junger Mensch" (11) who becomes noticeably more intelligent during his stay at the sanatorium $(132,582)$. In the chapter section "Bei Tienappels. Und von Hans Castorps sittlichem Befinden”, the narrator introduces Castorp as "weder ein Genie noch ein Dummkopf" (53), yet he refrains from describing him as average, "aus Achtung vor seinem Schicksal" (53). This hints at the intellectual transformation that Castorp undergoes, development which is connected to Castorp's enthusiastic reception of the sanatorium environment ("diese[r] genialen Gegenden" [902]). ${ }^{536}$ In the chapter section "Mynheer Peeperkorn (Des Weiteren)", Castorp acknowledges this link between intellectual development and the sanatorium as follows: "[I]ch [habe] mich dem Prinzip der Unvernunft, dem genialen Prinzip der Krankheit unterstellt, [...] und bin hier oben [im Sanatorium] geblieben” (925). In contrast, Joachim protests (in accordance with both his loyalty to life and an absence of intellectual growth): "[W]ir [sind] doch hier, um gesünder, und nicht um gescheuter zu werden" (582).

The promotion of Mind at the sanatorium follows the physical separation of the Swiss Alps from the rest of Europe (which is symbolic of life). Castorp's following ruminations in the chapter section "Vom Gottesstaat und von übler Erlösung" consequently illustrate a connection between distance and reflection: "[M]an [blickt] aus der beschaulichen Abgeschiedenheit von fünftausend Fuß auf Welt und Kreatur hinab[] und [macht] sich seine Gedanken" (588; see also 569). The interrelation of distance and contemplation in this passage is appropriated by Naphta, who praises the bed as a symbol of inactivity in opposition to life (568). Castorp's sanatorium lounge chair "mit dem dreiteiligen Polster und der Nackenrolle" (411) ${ }^{537}$ and the related "horizontale Lage" (139) of the rest cure are consequently both symbolic of death (487) and conducive to reflection. This last function is illustrated by Castorp's "grübeln und träumen” while reclining (577), and by his claim to have learnt and thought more in this position than he ever had in Hamburg (569). Castorp's horizontal ruminations correspond selectively to the text Ecce

\footnotetext{
${ }^{536}$ Castorp also predicts that he and his cousin will become cleverer following their acquaintance with Naphta (582).

${ }^{537}$ Castorp uses the word "Bett" to describe his lounge chair (569).
} 
Homo, in which Nietzsche praises time spent lying as favourable to reflection: "Stillliegen [...] ... Aber das heisst ja denken!"538 The reader's knowledge of this text allows his or her ironic comparison of Castorp's modest daydreaming with the megalomaniacal genius of Nietzsche, whose thoughts "wie ein Blitz [auf]leuchtet[en]". 539

However, the interrelation of disease and Mind in Der Zauberberg is negated in the first half of the chapter section "Forschungen" by the presentation of serious literature as a matter for short-term patients, i.e. those only mildly ill and with a good chance of recovery. Castorp's engineering textbook Ocean Steamships thus symbolises life, ${ }^{540}$ and its neglect (104-05, 414-15) reflects Castorp's primary interest in disease and death. ${ }^{541}$ The long-term, chronically-ill patients at the sanatorium, on the other hand, prefer to read novels and sensational literature. Die Kunst, zu verführen, for example, is so popular that the sanatorium patients fight over who is to read it next (414). This negation of an association between disease and the intellect establishes dialogical tension between Der Zauberberg and the texts by Novalis and Nietzsche discussed previously. This tension is also internalised within the novel. Castorp's fascination with death, for example, leads him to connect Mind and disease in concordance with the views of Novalis and Nietzsche. He is consequently surprised by the combination of stupidity and disease exhibited by Frau Stöhr: "Das ist so sonderbar, - krank und dumm [...]. Man denkt, ein dummer Mensch muß gesund und gewöhnlich sein, und Krankheit muß den Menschen fein und klug und besonders machen. So denkt man sich in der Regel." (149) Castorp reconciles the reading habits at the sanatorium with his own conviction that Mind and disease are linked by concluding that the dying (i.e. those closest to death) must read serious literature (414). The intertextually-rich relationship between Mind and disease triumphs over disease and stupidity at the end of "Forschungen", when Castorp's pathologically enhanced intellect comprehends the interrelation of life and disease (433).

The connection between Mind and disease allows the latter to be seen as a

\footnotetext{
538 Nietzsche KSA 6, p. 326; see also Nietzsche KSA 2, p. 234.

${ }^{539}$ Nietzsche KSA 6, p. 339.

540 Serious literature is associated with "eine[r] Verbindung mit dem Leben der Ebene" (414); the lifeaffirming Joachim consequently spends his rest cure periods studying Russian grammar (101).

${ }^{541}$ See 2.4 , pp. 44-47.
} 
particularly human quality. In the chapter section "Operationes spirituales", Naphta declares: "Krankheit sei höchst menschlich [...]; denn Mensch sein, heiße krank sein [...]; [der Mensch] sei, mit einem Worte, in desto höherem Grade Mensch, je kränker er sei” (700-701). ${ }^{542}$ This claim is upheld not only by the sanatorium patients but also by the medical attendants. Director Behrens, for example, has prominent, bloodshot eyes and blue cheeks (73), Dr Krokowski is as pale as a corpse and has yellow teeth, and nurse Mylendonk's face is disfigured by an enormous sty below her eye (254). In addition, Behrens walks with the posture of a chimpanzee with arms dangling forward and bowed legs $(75,99,139)$, Dr Krokowski limps, and nurse Mylendonk’s body is “kümmerlichen Wuchses, ohne Formen" (254). In the context of the early $20^{\text {th }}$-century interest in eugenics, these physical abnormalities in Der Zauberberg illustrate deviations from an ideal of health.

The geographical separation of the Swiss Alps from the rest of Europe might suggest that this prevalence of disease is specific to sanatorium Berghof. However, Europe is introduced to the reader via the demise of Castorp's Hamburg relatives $(34,45)$; this suggests that the sanatorium inhabitants in fact reflect human pathology in general. The diseased state of humanity is taken for granted by Dr Krokowski, who reacts with surprise when the recently-arrived Castorp claims to be completely healthy. "Wahrhaftig? Aber dann sind Sie [Castorp] eine höchst studierenswerte Erscheinung! Mir ist nämlich ein ganz gesunder Mensch noch nicht vorgekommen." (31) ${ }^{543}$ Naphta's and Krokowski's view of human beings as intrinsically diseased relates referentially to texts by Novalis, Nietzsche and Schopenhauer. In "Einige Sätze des Brownischen Syst[ems]", for example, Novalis describes the relationship between human beings and disease as follows: "Krankh[eiten] zeichnen den M[enschen] vor den Tieren und Pflanzen aus - zu Leiden ist der Mensch geboren". 544 A subsequent fragment explains the human relationship to disease as consequent to Mind: "Gebrechlichkeit, Vergänglichkeit ist der Charakter der mit Geist verbundenen Natur. Erzeugt von der Tätigkeit und Universalität, von der erhabenen

\footnotetext{
542 Thomas Mann reiterates this idea in the essay "Goethe und Tolstoi. Fragmente zum Problem der Humanität": "[U]nd die Frage [...] ist, ob er nicht in desto höherem Grade Mensch sei, $[\ldots]$ je kränker er sei" (Mann 15.1, p. 833).

${ }^{543}$ Dr Krokowski also expresses the doubt that "'Mensch' und 'vollkommene Gesundheit' überhaupt Reimworte seien" (291).

${ }^{544}$ Novalis 3, p, 667; also quoted in E. Bertram, op. cit., p. 152.
} 
Personalität des Geistes". ${ }^{545}$ Similarly, Schopenhauer states that human suffering is greater than that of any other life form, following "die Deutlichkeit der Erkenntnis, die Klarheit des Bewußtseins" ${ }^{546}$ Nietzsche describes mankind as "das kranke Tier" according to the innate human tendency to defy nature using the intellect:

[Der Mensch] hat [...] auch mehr gewagt, geneuert, getrotzt, das Schicksal herausgefordert als alle übrigen Thiere zusammen genommen: er, der grosse Experimentator mit sich, der Unbefriedigte, Ungesättigte, [...] wie sollte ein solches muthiges und reiches Thier nicht auch das am meisten gefährdete, das am Längsten und Tiefsten kranke unter allen kranken Thieren sein? ${ }^{547}$

These intertexts enrich the reader's interpretation of the primary text by explaining Krokowski's and Naphta's conviction that human beings are innately sick as consequent to Mind's affiliation with disease.

\subsection{Conclusion}

The present chapter has demonstrated that intertextual links between the work of Freud and Novalis and the text of Der Zauberberg enable life to be interpreted as the sum of stimuli and an excitable body. The impact of these stimuli on the living organism is ambiguous: while necessary for maintaining life to the extent that they completely determine the organism and its behaviour, stimuli can also be damaging if too great a quantity are allowed to penetrate. These ideas are illuminated by intertextual connections to the work of Novalis, Schopenhauer, Nietzsche and Freud. The primary text elaborates on this interrelation of stimuli and disease by presenting bacteria as stimuli, and the reader's knowledge of the work of Novalis subsequently leads to the insight that life is synonymous with disease. In addition, intertextual relations between the work of Novalis and Nietzsche and the primary text indicate the ability of disease to stimulate the organism, an idea that is traced in Der Zauberberg to the creation of matter and organic material by the pathological stimulation of Mind. The primary text's further correspondence to the philosophy of Novalis,

\footnotetext{
${ }^{545}$ Novalis 3, p. 658.

${ }^{546}$ Schopenhauer I, p. 426; see also ibid., pp. 425-26.

${ }^{547}$ Nietzsche KSA 5, p. 367.
} 
Schopenhauer, Nietzsche and Freud leads to the reader's recognition of a link between disease and Mind, which in turn suggests that human beings, as representatives of Mind, are intrinsically diseased. 


\section{Chapter 4. Disease and Culture}

\subsection{The environmental causes of disease}

In the previous chapter, I established that Naphta and Krokowski share the conviction that human beings are inherently diseased. This view is challenged in Der Zauberberg by Settembrini, who considers Naphta's relation of sickness to Mind to be "[eine] geistige Rückneigung in die Anschauung [von] finsteren, gequälten Zeiten” (152). Settembrini’s implicit criticism of the Middle Ages is linked to his negation of Romanticism, following the coexistence of the theme of the Middle Ages and Romantic ideas within the characterisation of Naphta. ${ }^{548}$ Settembrini's rejection of Naphta's belief in disease as intrinsic to human beings thus simultaneously both opposes this idea from within the work of Novalis as well as Nietzsche's apparent adoption of the Mind/disease constellation from Romanticism. ${ }^{549}$

Settembrini argues instead that the origin of suffering can be found in society: "Fast alle Leiden des Individuums [sind] Krankheiten des sozialen Organismus” (373). This argument has implications for the human experience of life, since if pain has a social origin it can potentially be eliminated (373-74). With this goal in mind, Settembrini is engaged during the novel in writing a contribution to the encyclopaedia Soziologie der Leiden (373), ${ }^{550}$ which aims to analyse the forms of suffering, "deren Ursachen man zuerst erkennt und dann aufhebt" (373). Ironically, this optimistic example of Enlightenment logic is illogical, as common sense (based on logic) tells us that suffering cannot be eradicated so easily. Undermining Settembrini's work by poking fun at its rationalist approach and inherent belief in the power of the intellect, the text of Der Zauberberg indirectly mocks the work of Freud, who presents the conscious/intellect as the key to both preventing and curing neurosis. 551

Despite the irony of Settembrini's view of suffering, the theme of disease and

\footnotetext{
${ }^{548}$ See 2.2 , p. $30 ; 2.4$, pp. 41-42; 2.5, pp. 50-51.

${ }^{549}$ See 3.5, pp. 99-100, 103-05.

${ }^{550}$ See 2.4, p. 48.

${ }^{551}$ Freud XIII, p. 16. See 3.3, pp. 83-84.
} 
society is explored in depth in Der Zauberberg, particularly in chapters three and seven. Analysis of these chapters reveals that, unlike the clearly demarcated, antithetical positions of Naphta and Settembrini, the Romantic view of human beings as intrinsically diseased occupies subtly different ground to the idea that disease has a sociological cause. Whereas human susceptibility to disease is illustrated in Der Zauberberg by a variety of types of ill health, ${ }^{552}$ the following subchapters will present the argument that disease caused by society is linked to the specific symptoms of exhaustion and tension. These two symptoms are predominant in Der Zauberberg. In the chapter section "Frühstück", for example, Frau Stöhr responds to an enquiry about her health with a complaint of "Schlaffheit" (70), whereas her neighbour, Fräulein Engelhart, feels "innerlich gespannt und rastlos" (71). Exhaustion and tension are also the themes of two sections from chapter seven. "Der große Stumpfsinn" depicts the sanatorium patients in the grips of chronic lethargy that they attempt to alleviate with superficial entertainment such as drawing figures with their eyes closed and eating copious amounts of chocolate (953). "Die große Gereiztheit", in contrast, depicts an outburst of irrational violence (1038) as well as a duel between two formerly rational intellectuals (Settembrini and Naphta) (1070). ${ }^{553}$ The exhaustion and tension portrayed in Der Zauberberg is never affiliated with a particular disease. This heuristic gap sparks the reader's interest and provokes the following question: what diseases correspond to the symptoms of lethargy and tension portrayed in Der Zauberberg? The present chapter aims to answer this question by investigating the intertextuality of the novel, and will also explore to what extent society within the novel has contributed to the development of disease.

\subsection{Lethargy and boredom}

The intertexts that most clearly explain the symptom of lethargy in Der Zauberberg are a selection of fragments by Novalis that discuss indirect asthenia. ${ }^{554}$ Novalis's understanding of indirect asthenia follows the medical system of the Scotsman John Brown, who classifies

\footnotetext{
${ }^{552}$ See 3.5, p. 104.

553 Although Naphta's nature is described as "Verwirrung" (see 2.5, p. 52 (footnote 298), he argues using $\operatorname{logic}(614)$.

${ }^{554}$ See also 3.1, p. 72.
} 
disease according to an imbalance of stimulation and excitability. ${ }^{555}$ In his adaptation of Brown's system, ${ }^{556}$ Novalis defines an excess or lack of stimulation as Sthenie (sthenia), and pathological states of excitability as direkte or indirekte Asthenie (direct or indirect asthenia). ${ }^{557}$ The lethargy portrayed in Der Zauberberg is explained by the concept of indirect asthenia as "[eine] Constitution mit mangelnder Reitzbarkeit", 558 i.e. exhaustion. Accordingly, Hans Castorp can be diagnosed as indirectly asthenic: he slouches (52), he finds work arduous (56), his delicate health exempts him from military service (57), and the real reason for his visit to the sanatorium is his exhaustion after the exertion of studying for his engineering exam (59). Although Castorp's “Neigung, zu 'dösen"” (50) can also be explained by his diagnosis with anaemia in the chapter section "Frühstück" (74), ${ }^{559}$ his description as a lethargic "Typus" (59) suggests a more general category of disease and is an intertextual marker that connects Castorp's symptoms communicatively to Novalis's conception of asthenia as a diseased "Constitution". 560

Castorp's lethargy is also described in Der Zauberberg in terms of nervous exhaustion: "Angestrengte Arbeit zerrte an seinen Nerven, sie erschöpfte ihn bald" (56). This passage from the chapter section "Bei Tienappels. Und von Hans Castorps sittlichem Befinden" corresponds referentially to Novalis's theory that indirect asthenia can be caused by an excess of stimuli. ${ }^{561}$ This theory is based on Novalis's belief that sthenia ("überflüssige[] Incitation" "562) can lead to indirect asthenia: "Eigentlich sind Sth[enie] und

\footnotetext{
555 Health, in contrast, is dependent on a balance between asthenia and sthenia: "In der Gesundheit sind Asthenie und Sthenie vereinigt [...]. Die Bestandth[eile] d[er] Ges[undheit] sind A[sthenie] and S[thenie]." (Novalis 3, p. 323)

556 Novalis's reception of Brown's ideas was influenced by the contemporary philosophers Schelling and Fichte (J. Neubauer, op. cit., pp. 373, 376).

${ }^{557}$ Novalis 2, p. 573.

558 Ibid.

${ }^{559}$ Here, Director Behrens concludes from Castorp's greenish tint that he is "total anämisch" (74), thereby confirming the family doctor's diagnosis of young Castorp as "blutarm" (50) in the chapter section "Bei Tienappels. Und von Hans Castorps sittlichem Befinden”.

${ }^{560}$ Novalis 2, p. 573.

${ }^{561}$ Ibid., p. 620. See 3.3, pp. 81-82.

562 Novalis 2, p. 573.
} 
ind[irecte] Asth[enie] [...] Eine Kranckheit mit 2 Stadien." 563 The relation of sthenia to indirect asthenia is explained by Novalis in terms of an indirectly proportional relationship between an organism's capacity to absorb stimuli and its excitability:

Sthenie und Asthenie sind verkehrte Synonymen [...]. In der St[henie] nimmt die Capacitaet zu und die Erregbarkeit ab - auf dem Puncte, wo die allzugroße Abnahme der Erregbarkeit die Zunahme der Capacit[aet] vermindert fängt die indirecte Asth[enie] an. ${ }^{564}$

Interpreted according to these fragments by Novalis, Castorp's lethargic constitution appears to have been caused by exposure to excessive stimulus, and thus illustrates "[eine] Abstumpfung der Sinne. (Gewöhnung, Erschöpfung [...] etc.)". 565

Novalis regards indirect asthenia due to overstimulation as a contemporary phenomenon, ${ }^{566}$ a view that suggests Castorp's lethargy is related to culture rather than symptomatic of the human condition. This interpretation is supported by the text Menschliches, Allzumenschliches, in which Nietzsche, like Novalis, traces the cause of disease (modern neuroticism) to overstimulation:

Die Summe der Empfindungen, Kenntnisse, Erfahrungen, also die ganze Last der Cultur, ist so gross geworden, dass eine Ueberreizung der Nerven- und Denkkräfte die allgemeine Gefahr ist, ja dass die cultivierten Classen der europäischen Länder durchweg neurotisch sind und fast jede ihrer grösseren Familien in einem Gliede dem Irrsinn nahe gerückt ist. ${ }^{567}$

The reader's knowledge of these texts by Novalis and Nietzsche allows him or her to interpret Castorp's lethargy as representative of widespread malaise within modern culture.

Castorp's lethargy can furthermore be traced to the devaluation of life. In the chapter section "Satana", Settembrini compares the sanatorium to Hades, "wo Tote nichtig

\footnotetext{
${ }^{563}$ Novalis 3, p. 657; see also J. Neubauer, op. cit., p. 370.

564 Novalis 3, p. 349.

565 Novalis 2, p. 549.

566 Ibid., p. 604. Novalis's observation tacitly includes both indirect and direct asthenia. Direct asthenia is discussed extensively in subchapter 4.5 of this thesis (see, for example, p. 129).

${ }^{567}$ Nietzsche KSA 2, p. 204.
} 
und sinnlos wohnen" (90). This passage relates metatextually to Schopenhauer's note of life's "Bestandlosigkeit [...] [und] Leerheit"; 568 however, Schopenhauer's metaphysical conception of life as inherently meaningless is modified in Der Zauberberg in the idea that meaning in life has been undermined by environmental factors. Settembrini, for example, notes that within six months of their arrival, most patients have lost interest in anything other than "Flirt und Temperatur" (302). This use of the word "Flirt" selectively links Settembrini's observation to a passage from the essay "Zeitgemäßes über Krieg und Tod”, in which Freud warns against the repression of death in contemporary society:

Das Leben verarmt, es verliert an Interesse, wenn der höchste Einsatz in den Lebensspielen, eben das Leben selbst, nicht gewagt werden darf. Es wird so schal, gehaltlos wie etwa ein amerikanischer Flirt, bei dem es von vornherein feststeht, daß nichts vorfallen darf. ${ }^{569}$

Freud's belief that modern society devalues life is anticipated by Nietzsche, who condemns modern society as a degenerate form of Alexandrian/Socratic culture in Die Geburt der Tragödie. Nietzsche consequently traces the inability to live life fully - "[das] Urleiden der modernen Kultur" ${ }^{\prime 570}$ - to a modern loss of confidence in the positivist view disseminated by Socrates that everything can be known. The result is a fear of consequences: "[Der moderne] Mensch [erschrickt] vor seinen Consequenzen [...] und unbefriedigt es nicht mehr wagt, sich dem furchtbaren Eisstrome des Daseins anzuvertrauen: ängstlich läuft er am Ufer auf und ab." ${ }^{571}$ Contemporary art reflects this inability to engage with life, and Nietzsche subsequently condemns opera as a trivial musical form typical of decadent modernity. ${ }^{572}$ Nietzsche's attack of modern art is reflected in Der Zauberberg in the satirical portrayal of the patients' preference for light literature (413-14), ${ }^{573}$ in their fleeting obsessions with the "amateur" hobbies of photography, philately, and drawing (171), and

\footnotetext{
568 Schopenhauer II, p. 819.

${ }^{569}$ Freud X, p. 343.

${ }^{570}$ Nietzsche KSA 1, p. 119.

571 Ibid.

572 Ibid., pp. 120-26.

${ }^{573}$ See 3.5, p. 103.
} 
in their enthusiasm for silly activities such as attempting to tie their shoelaces with one hand (172) and drawing pigs with their eyes closed (953).

The modern devaluation of life leads in Der Zauberberg to a perverse attitude towards health and disease. Contrary to the Hippocratic Oath, the sanatoriums of the region stand accused (by Settembrini) of killing their patients by using dirty hypodermic needles (98), of placing their patients' health second to profit by encouraging them to drink alcohol (to the establishment's pecuniary gain) (98), and of marketing the formerly unprofitable summer season as particularly effective in order to increase sales (97). ${ }^{574}$ This perverse attitude towards health is shared by the patients themselves. In the chapter section "Satana macht ehrrührige Vorschläge”, for example, Settembrini relates the story of a healthy young woman who falsified her thermometer readings in an attempt to remain at the sanatorium (134-35). When this deception was discovered, the young woman attempted to make herself ill by swimming in an icy lake. Yet she remained healthy, and was eventually sent home, protesting: "Was soll ich da unten? [...]. Hier ist meine Heimat!" $(135)^{575}$ This deliberate attempt to become ill is mirrored by the flagrant disregard of Herr Albin and Fritz Rotbein for their own health. Herr Albin "versuch[t] [Gott]" (122) by smoking cigarettes during the open-air rest cure and by refusing to wear a coat or to wrap himself in a blanket. Fritz Rotbein sabotages his recovery and is rendered "mehr tot als lebendig" (165) when he rebels against his prescribed diet, and is discovered sitting in bed, "vor sich ein Glas dickes, dunkles Bier, eine Salamiwurst, ein derbes Stück Schwarzbrot und eine Gurke" (165).

The devaluation of health and life reaches a climax in the chapter section "Der große Stumpfsinn", ${ }^{576}$ in which Hans Castorp is shown in a state of chronic apathy. Director Behrens offers the following appraisal: "Castorp, alte Schwede, Sie langweilen sich. Sie lassen das Maul hängen, ich sehe es alle Tage, die Verdrossenheit steht Ihnen an der Stirn

\footnotetext{
574 The administration of sanatorium Berghof is consequently described as "[ein] kaufmannische[s] Zentrum" (200), whose manager casts "einen kalten und sachlich musternden Blick auf die Klienten" (201). Director Behrens is merely an agent of the sanatorium's shareholders (201).

575 Similarly, when Fränzchen von Oberdank's condition takes a sudden turn for the worse, she tosses her handbag into the air and rejoices: "Hurra, ein Jahr muß ich bleiben!" (451)

576 The title of this chapter section reflects Novalis's description of indirect asthenia as "Stumpfheit" (Novalis 3 , p. 656).
} 
geschrieben. Sie sind ein blasierter Balg" (947). ${ }^{577}$ Castorp's apathy is so extreme that he offers Behrens no more than a movement of his head to indicate he is listening, and his eventual reply (after Behrens has talked without interruption for the duration of nearly three pages) is short, disinterested and "schlaff" (950). The moroseness associated with Castorp's ennui is intensified to the point of pain in the chapter section "Er versucht sich in französischer Konversation", in which Nurse Berta's desperate chatting leads the narrator to note: "[Sie sprach] nicht nur geziert, sondern geradezu gequält und machte bei näherer Prüfung den Eindruck, als habe unter der Folter der Langeweile ihr Verstand gelitten" (16465). Nurse Berta's amalgamation of boredom and pain selectively parallels Schopenhauer's inclusion of boredom among life's various forms of anguish. ${ }^{578}$ However, this essentially Romantic view of human suffering is offset in Der Zauberberg by its $20^{\text {th }}$-century, sociological framework. Nurse Berta's state of tortured boredom thus appears to have been caused by her job at the sanatorium rather than by life itself. This is illustrated by her reference to the imminent demise of a patient as "die Erlösung ja nur für ihn [...] nicht auch für sie" (165), since her suffering will continue with new responsibility for another charge. Berta's boredom consequently appears linked most referentially to Nietzsche's view of ennui as a cultural phenomenon in Menschliches, Allzumenschliches. ${ }^{579}$

In subchapter 4.1, I noted that the presentation of disease as a sociological phenomenon in Der Zauberberg appears alongside the Romantic concept of mankind as inherently diseased. ${ }^{580}$ This interesting coexistence between Romantic and early $20^{\text {th }}$ century ideas is developed and clarified by the relationship of the primary text to the excerpts by Novalis, Nietzsche and Freud examined above. These texts present disease and the devaluation of life as both the consequence of modern culture and also something endemic and specific to human beings. The reader of Der Zauberberg can interpret the message of the primary text accordingly: humankind is indeed saturated with disease, as

\footnotetext{
577 Behrens subsequently diagnoses Castorp with a streptococcal infection (949), a common pathogen that lacks the Romantic connotations of tuberculosis. This exchange of the Romantic with the every-day ironically reflects the boredom prevalent in "Der große Stumpfsinn".

${ }^{578}$ Schopenhauer I, p. 432.

${ }^{579}$ Nietzsche KSA 2, p. 346.

580 See 4.1 , pp. 107-08.
} 
Dr Krokowski has suggested (291), but this endemic pathology is a phenomenon specific to modern society as it is portrayed in the novel.

\subsection{Boredom, time and entertainment}

Hans Castorp's state of extreme apathy in "Der große Stumpfsinn" falls within the final chapter of the novel, a structural position which suggests that his tendency to be lethargic has been exacerbated by his time at the sanatorium. This environmental influence on mood is linked to the distortion of time: in the chapter section "Exkurs über den Zeitsinn", the narrator challenges the assumption (inherent in the German word "Langeweile") that boredom follows a perception of time as slow, suggesting instead that the cause of ennui is “eine krankhafte Kurzweiligkeit der Zeit" (160). This premise is confirmed by an evident proportional relationship between temporal acceleration and the amount of time spent at the sanatorium. The newly-arrived Castorp, for example, feels that time passes slowly, whereas for Joachim, an established patient, time rushes by. For this reason, Joachim declares: “[I]ch kann mich gewissermaßen an dir [Castorp] festhalten, seit du da bist” (162).

This link between temporal acceleration and the length of time spent at sanatorium Berghof invites closer analysis: what exactly at the sanatorium promotes temporal distortion? The answer to this question can be found in a passage from the chapter section “Exkurs über den Zeitsinn”, in which accelerated time is placed in opposition to life:

Die ersten Tage an einem neuen Aufenthalt haben jugendlichen, das heißt starken und breiten Gang [...]. Dann, in dem Maße, wie man 'sich einlebt' macht sich allmähliche Verkürzung bemerkbar: wer am Leben hängt oder, besser gesagt, sich ans Leben hängen möchte, mag mit Grauen gewahren, wie die Tage wieder leicht zu werden und zu huschen beginnen [...]. (160-61) ${ }^{581}$

Roughly summarised, this passage links time experienced as slow with youth, and suggests that condensed time is synonymous with an acceleration of life towards death. ${ }^{582}$ Thus, the

\footnotetext{
581 Temporal distortion in Der Zauberberg also takes the form of confused duration. Time appears "zugleich unnatürlich kurz und unnatürlich lang" (334), and furthermore: "[K]urzweilig und langweilig [...]. Das ist zuweilen schwer zu unterscheiden" (131-32).

582 Accelerated time is subsequently associated with old age (161); in addition, the narrator regards a poorly developed sense of time as "ein Zeichen von ursprünglicher Lebensschwäche” (161).
} 
link between accelerated time and boredom in Der Zauberberg indicates that Castorp's ennui after nearly seven years at sanatorium Berghof is due to the sanatorium's atmosphere of death and disease. This premise is strengthened by the description of boredom as a resident demon in the chapter section "Der große Stumpfsinn" (951). The connection between accelerated time, death and disease also has implications for the interpretation of the novel's structure, the first half of which charts the initial six months of Castorp's sanatorium stay, and the second half of which chronicles the final six and a half years. This compression of narrative time in the second half of Der Zauberberg is recognised by the narrator, who pronounces towards the novel's conclusion: "Ihre inhaltliche Zeit ist derart ins Rollen gekommen, daß kein Halten mehr ist" (947). The acceleration of time within the novel reflects life's headlong rush towards death, and consequently illustrates the death drive presented in the work of Novalis, Schopenhauer, Nietzsche and Freud. ${ }^{583}$

The association of death and disease with temporal acceleration in Der Zauberberg is complemented by the relation of death to other forms of temporal distortion. The units of day, hour and year, for example, dissolve at the sanatorium into a fluid mass, ${ }^{584}$ and Castorp comes to the conclusion in the chapter section "Satana macht ehrrührige Vorschläge" that time resembles "eine stumme Schwester", a thermometer without any markings that can be interpreted at whim (141). Time unshackled from units of measurement is synonymous with the Christian concept of eternity (and with the related theme of death). This timelessness is linked to sanatorium existence in the latter's description as "[d]as Leben ohne Zeit, [...] das tote Leben" (951). ${ }^{585}$ How then to explain sanatorium routine, which divides the day into mealtimes and rest cure periods? The narrator of Der Zauberberg characterises such measured time as "dem Lebensgefühle selbst so nahe verwandt und verbunden" (159). In addition, metre is associated with life when Joachim credits the division of music into bars with creating meaning (175), and when Settembrini praises rhythmic music for its ability "die Zeit [zu wecken]" (175). Sanatorium

\footnotetext{
${ }^{583}$ See 2.5 , pp. 60-61.

584 The day becomes one with every other $(280,287)$, a quarter of an hour lasts an eternity (735), the seasons are confused (144-45, 545-47), and Castorp eventually forgets how old he is (819).

585 Joachim anticipates this passage in the chapter section "Im Restaurant": "[E]s ist gar keine Zeit, und es ist auch kein Leben" (27).
} 
routine thus appears at first glance to oppose the dissolution of time's units associated with death. However, the day's regulation activities do not keep the patients alert or active; on the contrary, they appear to contribute to the widespread apathy. The reason for this can be found in the monotonous effect of repetition. The division of the day into five mealtimes and two rest cure periods, for example, leads to the impression that it is "immer derselbe Tag" (279; see also 287). In the following passage, the equivalence of division and unity is further aligned with the disintegration of death: ${ }^{586}$ "Der zerkleinerte und künstlich kurzweilig gemachte Tag war [Castorp] buchstäblich unter den Händen zerbröckelt und zunichte geworden" (292-93). ${ }^{587}$

The interchangeability of temporal fragmentation and temporal unity in Der Zauberberg is also clear from the description of sanatorium mealtimes. The blonde girl seated opposite Castorp in the dining room eats yoghurt at the first and second breakfasts $(70,106)$, and varies her diet at lunch only minimally with a bowl of "Crème d'orge" (115). Overall, Castorp has the impression that the lunch guests have not left the table since the first breakfast (115). Castorp's insight into the illusory nature of time culminates in his perception of "eine[s] stehenden Jetzt[es] [...] [,] eine[r] ausdehnungslose[n] Gegenwart, in welcher man dir ewig die Suppe bringt" (280). This passage referentially parallels Schopenhauer's concept of the true nature of time as an amorphous moment (Nunc stans). ${ }^{588}$ By equating repetition with stasis, the passages from Der Zauberberg quoted above reconcile the concept of Nunc stans with Schopenhauer's belief in reincarnation and Nietzsche's related concept of the ewige Wiederkunft. ${ }^{589}$ Furthermore, this coexistence of repetition and stasis in Der Zauberberg reflects Schopenhauer's following portrayal of the immortality of the species from Die Welt als Wille und Vorstellung: "[D]enke man sich jenen Wechsel von Tod und Geburt in unendlich schnellen Vibrationen, und man hat die

\footnotetext{
${ }^{586}$ See 2.5 , pp. 52, 54.

587 A causal link between repetition/fragmentation and compressed time is established by aligning the observation that repetition causes monotony with the narrator's previous definition of boredom as "eine krankhafte Kurzweiligkeit der Zeit infolge von Monotonie" (160).

${ }^{588}$ Schopenhauer II, p. 626.

${ }^{589}$ See 2.2, p. 34.
} 
beharrliche Objektivation des Willens, die bleibenden Ideen der Wesen vor sich, fest stehend wie der Regenbogen auf dem Wasserfall". 590

However, the following passage from Der Zauberberg complicates the relationship between the novel and the work of Nietzsche and Schopenhauer discussed above by appearing to connect Schopenhauer's Will to the Romantic concept of death: "Und wenn die vielfache Gliederung und Einteilung des Tages diesen kurzweilig machte, so war es bei Nacht die verschwimmende Einförmigkeit der schreitenden Stunden, was in der gleichen Richtung wirkte." (308) Here, the reader is confronted with metatextual parallels to both Nietzsche's ewige Wiederkunft, present as the repetition inherent in the day's division, and Schopenhauer's Nunc stans, present as the temporal unity of the night. However, the interpretation of Schopenhauer's amorphous Will as synonymous with the night also clearly recalls Novalis's Romantic concept of death as dissolution of form. ${ }^{591}$ Moreover, the primary text's association of night with day suggests a link between death's dissolution and Nietzsche's ewige Wiederkunft. This paradoxical combination of concepts associated with life (the Will to live, eternal recurrence) and the Romantic concept of death as dissolution demonstrates the true complexity of the attitudes towards death within the novel. Several scholars have noted that Mann's own view of Der Zauberberg as lifeaffirming fails to be upheld by the text itself. ${ }^{592}$ The intertextual web suggested by the passage analysed above confirms this observation by indicating that the Romantic view of death has infiltrated concepts associated with life.

Although the previous paragraphs have established that fragmentation in Der Zauberberg is largely synonymous with temporal acceleration and unity, it is also uniquely and paradoxically used to characterise entertainment. After dinner, for example, the patients are free to cast "ein[en] oder de[n] andere[n] Blick in den stereoskopischen

\footnotetext{
${ }^{590}$ Schopenhauer II, p. 612. Schopenhauer describes the immortality of the species in terms of a waterfall once more on page 617 of the same volume.

${ }^{591}$ See 2.5, pp. 52, 53-54.

${ }^{592}$ See, for example, Mann. "Einführung in den Zauberberg”, op. cit., pp. 326-37, and Mann's following letter to Alberto Mondadori of 19 June 1950: "Im 'Zauberberg' ist die Krankheit nicht als Gnadenzustand, sondern beinahe als Laster geschildert.” (H. Wysling (ed.). Thomas Mann. Selbstkommentare: Der Zauberberg, op. cit., p. 158). Two critics who disagree with Mann's view are Børge Kristiansen and Werner Frizen (B. Kristiansen. Thomas Manns Zauberberg und Schopenhauers Metaphysik, op. cit.; W. Frizen. Zaubertrank der Metaphysik, op. cit.).
} 
Guckkasten, das kaleidoskopische Fernrohr und die kinematographische Trommel” (159) - these objects present the viewer with static single images and short scenes. The affiliation of fragmentation with entertainment is explained by Nietzsche's texts Die Geburt der Tragödie and Der Fall Wagner. In Die Geburt der Tragödie, Nietzsche initiates his criticism of modern fragmentation (“[der moderne Mensch] will nichts mehr ganz haben"), ${ }^{593}$ and in Der Fall Wagner, he develops this further in his refutation of modern culture through the focus of art. ${ }^{594}$ In this last text, Nietzsche attacks Wagner for allowing modern fragmentation to infect music: "Wagner konnte nicht aus dem Ganzen schaffen, er hatte gar keine Wahl, er musste Stückwerk machen, 'Motive', Gebärden, Formeln, Verdopplungen und Verhundertfachungen". ${ }^{595}$ This description of Wagner is reflected in Der Zauberberg in the figure of Mynheer Peeperkorn, a social "Dirigent" (831) who conducts an ensemble of admirers with the power of his personality, yet is unable to utter a complete sentence (832). Peeperkorn instead relies on "Kulturgebärden" (864) to convey the missing meaning from his broken speech, in selective recollection of Wagner's alleged "Überzeugungskraft der Gebärde". 596

Nietzsche's disapproval of decadent fragmentation is anticipated by Novalis, who declares: "Einheit muß jede Darstellung haben - wenn Sie Eine Darstellung - Ein Ganzes seyn will [...]. [Ohne die wäre es] kein Kunstwerk - sondern nur ein Sack voll Kunstfragmente". ${ }^{597}$ This sack of fragments is illustrated in Der Zauberberg in a scene from the chapter section "Totentanz", in which Castorp and Joachim accompany Karen Karstedt to the cinema. Here, the three friends are presented with short, thematically unrelated scenes from diverse locations around the world. These scenes are portrayed negatively: "In der schlechten Luft [...] flirrte eine Menge Leben, kleingehackt, kurzweilig und beeilt, in aufspringender, zappelnd verweilender und wegzuckender Unruhe” (479). This unpleasant impression is subsequently linked to disease when the cinema audience succumbs to

\footnotetext{
${ }^{593}$ Nietzsche KSA 1, p. 119.

${ }^{594}$ Nietzsche KSA 6, pp. 9-53.

${ }^{595}$ Ibid., p. 35; also quoted in P. Pütz. Kunst und Künstlerexistenz bei Nietzsche und Thomas Mann. Bonn: Bouvier Verlag, 1963, p. 94.

${ }^{596}$ Nietzsche KSA 6, p. 29.

${ }^{597}$ Novalis 2, p. 581.
} 
“ein[em] Gefühl der Ohnmacht" (482). Furthermore, their silence "hat[] etwas Nervloses" (480), and their hands "l[ie]gen ohnmächtig vor dem Nichts" (480). The clearly pathological effect of fragmentation on the cinema audience reiterates the symptoms of indirect asthenia caused by overstimulation discussed in subchapter 4.2. ${ }^{598}$ Moreover, the intertextual parallels between Der Zauberberg and Nietzsche's Wagner critique discussed above suggest that the pathological effect of fragmentation is linked to decadence.

Fragmented time is once again shown to be synonymous with temporal unity following the description of the cinematic experience in terms of Schopenhauer's Nunc stans: "[D]er Raum war vernichtet, die Zeit zurückgestellt, das Dort und Damals in ein huschendes, gaukelndes, von Musik umspieltes Hier und Jetzt verwandelt" (481). This passage reiterates the association of Schopenhauer's Nunc stans with a Romantic view of death, following the associations of both the word "huschendes" and music with death. ${ }^{599}$ By setting these intertextual links to Schopenhauer's Nunc stans and to the Romantic view of death alongside the affirmation of Nietzsche's critique of Wagner discussed in the previous paragraphs, the text of Der Zauberberg juxtaposes the Romantic affirmation of death with decadence. This intertextual contiguity suggests that both the Romantic affirmation of death and decadence are the objects of Mann's criticism. In fact, Thomas Mann conceivably presents Romanticism and decadence together in order to indicate a causal relationship between the two. Thus, the warning presented by the primary text about the continued affirmation of Romanticism within the $20^{\text {th }}$ century ${ }^{600}$ is realised in the idea that Romantic views of death may have contributed to modern decadence.

\subsection{Entertainment and intoxication}

The cinema screening discussed above is popular with its audience of patients from the village and surrounding sanatoriums. In the darkness of the theatre, Castorp catches sight of Frau Stöhr, "ganz Hingabe; ihr rotes, ungebildetes Gesicht [...] im Genusse verzerrt" (480), and at the film's conclusion, the audience proves reluctant to surface from the world

\footnotetext{
${ }^{598}$ See 4.2, pp. 109-10.

${ }^{599}$ See above; see 2.5 , pp. 54-58.

${ }^{600}$ See 2.4 , pp. $43-44,45$.
} 
of images: “[M]an [...] schämte sich der Helligkeit und verlangte zurück ins Dunkel” (48081). This attraction to film reflects the general enthusiasm of the sanatorium patients for entertainment: at various points within the novel they play dominoes and bridge (129), pursue photography, philately and drawing (171), listen to music (966-71), and pass around sensational literature (413). An explanation for the sanatorium patients' desire to be entertained can be found in the work of Novalis, who observes: "Die Gegenstände der gesellschaftlichen Unterhaltung sind nichts, als Mittel der Belebung" ${ }^{601}$ This idea is most clearly illustrated in Der Zauberberg by the "Spannung und Leben" elicited among the patients in the dining room when Frau Hessenfeld wages bets on everything from the weather to the menu (449).

The sanatorium patients' demand for entertainment is directly proportional to the intensity of their boredom. During the course of the novel, as the patients' level of boredom increases, the hobbies with which they had previously occupied themselves are replaced by fanatical crazes. In the chapter section "Der große Stumpfsinn", for example, the sanatorium patients become obsessed with eating chocolate, to the extent that "[a]lle Welt [...] braune Münder [hatte]" (953). They also feel compelled en masse to draw human figures comprised of geometrical shapes in one pen stroke (953). These sanatorium crazes and the associated "wilde[] Modewut [...], der alles fanatisch unterlag" are described in terms of "Epidemien" (952). Indeed, following the association of boredom with indirectly asthenic lethargy, ${ }^{602}$ the sanatorium patients' eagerness to be entertained can be interpreted as pathological, an expression of their need to compensate deficient energy. This idea corresponds selectively and referentially to Novalis's note that weak individuals (i.e. indirectly asthenic people) crave sensation: "Je schwächer der Mensch, desto mächtiger, ahndungsvoller und behaglicher dünckt ihm ein leidenschaftlicher Zustand."603 The sanatorium patients' relationship to the stimulation of entertainment thus reiterates the link discussed in 3.1 and 3.4 between the primary text and the $18^{\text {th }}$-century custom of treating

\footnotetext{
${ }^{601}$ Novalis 2, p. 431. Nietzsche similarly considers culture to consist of "Reizmittel" (Nietzsche KSA 1, p. 116).

${ }^{602}$ See 4.2 , pp. $108-10$.

${ }^{603}$ Novalis 2, p. 548.
} 
indirect asthenia with "reitzenden Substanzen". 604

The intertextual relationship between Der Zauberberg and the work of Novalis is once again complemented by connections within the novel to Nietzsche's critique of Wagner. In Der Fall Wagner, for example, Nietzsche reveals a striking correlation with Novalis's concept of indirect asthenia by presenting Wagner's audience as a group of sickly individuals, "erstarrt, blass [...] [und] athemlos". ${ }^{605}$ These lethargic (indirectly asthenic) listeners crave Wagnerian music with its ability "müde Nerven zu reizen". ${ }^{606}$ According to Nietzsche, the weak Wagnerian falls victim to "[einem] Nicht-mehr-loslassen-Wollen eines extremen Gefühls". ${ }^{607}$ This passion follows the pathological nature of decadent stimulus: Nietzsche views Wagner's music as sick, ${ }^{608}$ and Wagner himself as a disease ("[i]st Wagner überhaupt ein Mensch? Ist er nicht eher eine Krankheit?”). ${ }^{609}$ The interrelation of stimulus, disease and decadence in Der Fall Wagner is mirrored in Der Zauberberg in the chapter section "Mynheer Peeperkorn (Des Weiteren)". Here, the frenzied festive mood of a group of patients is attributed to the stimulating presence of their leader and entertainer: "[D]ie seelische Hochspannung des Kreises [...] [war] auf die Einwirkung einer Herrschernatur unter den Anwesenden, auf die der Persönlichkeit unter ihnen, auf diejenige Mynheer Peeperkorns zurückzuführen" (849-50). ${ }^{610}$ This passage ironically presents the stimulating personality of Peeperkorn in terms of Wagner's music, which Nietzsche compares to "Blitz und Donner" as well as to "Leidenschaft". ${ }^{611}$ In addition, by embodying the stimulus desired by his audience, Peeperkorn clearly recalls Nietzsche's ascetic priest, ${ }^{612}$ whom Nietzsche describes in Zur Genealogie der Moral as "de[n] fleischegewordne[n] Wunsch

\footnotetext{
${ }^{604}$ Ibid., p. 41. See 3.1, p. 72; 3.4, p. 93.

605 Nietzsche KSA 6, p. 29.

${ }^{606}$ Ibid., p. 23. Novalis similarly observes: “[A]ller Reitz zieht an” (Novalis 2, p. 642).

${ }^{607}$ Nietzsche KSA 6, p. 29.

${ }^{608}$ Ibid., p. 22.

${ }^{609}$ Ibid., p. 21.

610 This power relationship can also be interpreted according to Nietzsche's division between "Herren und Sklaven" (Nietzsche KSA 5, p. 213). Thus, Peeperkorn's "Herrschernatur" $(850,867)$ contrasts that of his audience members, whom he ultimately denounces as "furchtsame[] Sklaven" (865).

${ }^{611}$ Nietzsche KSA 6, p. 25.

${ }^{612}$ See 2.4, p. 42 (footnote 260).
} 
nach einem Anders-sein". ${ }^{613}$ When Peeperkorn neglects his audience for a moment by engaging in conversation with Castorp, his guests sink into a stupor: "Demoralisation, Lethargie, Stumpfsinn hatten um sich gegriffen; die Gäste trieben Allotria wie eine unbeaufsichtigte Schulklasse. Mehrere waren am Einschlafen.” (859-60) In ironic metatextual correspondence with the ability of Wagner's music “die Erschöpftesten wieder aufzustacheln, die Halbtodten in's Leben zu rufen", ${ }^{614}$ Peeperkorn's renewed attention has an immediate reviving effect on his guests' failing stamina (860): “Man sei [wieder] frisch und munter, flott, fidel und bei der Sache mit Herz und Sinn.” (861)

The attraction of indirectly asthenic/decadent society to extreme sensation leads to the patients' use of intoxicating substances. This can be seen in their eager participation in the Shrovetide festivities in the section "Walpurgisnacht" (500-07), as well as in Castorp's penchant for drinking beer at breakfast (108). Castorp is also fond of smoking cigars, and traces this habit to the stimulating properties of tobacco:

[E]in Tag ohne Tabak, das wäre für mich der Gipfel der Schalheit, ein vollständig öder und reizloser Tag, und wenn ich mir morgens sagen müßte: heut gibt's nichts zu rauchen, - ich glaube, ich fände den Mut gar nicht, aufzustehen, wahrhaftig, ich bliebe liegen. (76-77)

Smoking is in fact presented in the novel as both a stimulus and a sedative ("[ein] pflanzliche[r] Reiz- oder Betäubungsmittel” [382; see also 110]). These properties are also common to alcohol: while Peeperkorn considers schnapps to be pure "Labung" (834), Castorp reacts to a glass of beer "als habe er zwei oder drei Atemzüge von Chloroform getan" (108). ${ }^{615}$ The ambiguous effects of tobacco and alcohol relate to Novalis's criticism of contemporary religion in terms of stimulus and sedation: "Ihre sogenannte Religion wirkt blos, wie ein Opiate: reizend, betäubend, Schmerzen aus Schwäche stillend." ${ }^{„ 16}$ Similarly, Nietzsche dismisses German Romantic music (i.e. Wagnerian decadence) as

\footnotetext{
${ }^{613}$ Nietzsche KSA 5, p. 366.

${ }^{614}$ Nietzsche KSA 6, p. 23.

615 Castorp's feeling of sedation persists over several pages of the novel (110-14). The dual effect of intoxication is related to the ambiguous affiliation of substances with both life and death discussed in 3.4 of this study (see pp. 92-94).
}

${ }^{616}$ Novalis 2, p. 447. 
"[ein] berauschendes und zugleich benebelndes Narkotikum". 617 These texts hint that the dual effects of intoxication and inebriation in Der Zauberberg may be pathological.

Indeed, a link between intoxication, inebriation and disease is established in the chapter section "Forschungen". Here, Castorp's feverish symptoms combine shivering (energy/stimulus) with numbness (lethargy): "Schwindel und Zittern [...] [vermischten sich mit] ein[em] Gefühl von Betäubung und Trunkenheit" (412). Subsequent passages in Der Zauberberg associate disease with either inebriation or stimulation. In the chapter section "Gedankenschärfe", for example, Castorp's usual reaction to alcohol is intensified by the sanatorium environment: “[D]as Frühstücksbier, sonst nur von mäßig benebelnder Wirkung auf seine Natur, [betäubte und lähmte] den jungen Mann heute vollständig” (108). In contrast, Director Behrens reacts to the poisonous effects of "zwei kleine Henry Clay's" (cigars) (385) with ecstasy:

Eisbeine, [...] kalter Schweiß, [...] linnenweiß das Gesicht, das Herz in allen Zuständen, [...] das Gehirn in einer Aufregung... Ich war überzeugt, daß ich abtanzen sollte [...]. [E]igentlich war es höchst fidel und eine rechte Festivität, obgleich ich kolossale Angst hatte [...]. Aber Angst und Festivität schließen sich ja nicht aus, das weiß jeder [...]. Na, ich wäre jedenfalls beinahe geschmolzen, mit wogendem Busen wollte ich abtanzen. (385)

Behrens' excitement at the possibility of dying anticipates the description of the diseased organism embracing its own demise in the subsequent chapter section "Forschungen" (432). ${ }^{618}$ Although only the vitalising effects of toxic/intoxicating substances in the examples given above reiterate the stimulating properties of disease, ${ }^{619}$ inebriation is also linked to disease via its ability to weaken the individual's attachment to life. This idea is illustrated in the chapter section "Schnee", in which Castorp's mental numbness, compared with the effects of both opium and alcohol, is caused by exposure to life-threatening cold

\footnotetext{
${ }^{617}$ Nietzsche KSA 1, p. 20. A connection between intoxicating substances and entertainment is furthermore established by Nietzsche's description of Wagner as both a "Leidenschaft" (Nietzsche KSA 6, p. 25) and an opiate that enables the audience to temporarily forget themselves: "Diese [Wagner Enthusiasten] verlangen nach Wagner als nach einem Opiat, - sie vergessen sich, sie werden sich einen Augenblick los... Was sage ich! fünf bis sechs Stunden!" (Nietzsche KSA 6, p. 325)

${ }^{618}$ See 2.5, p. 60.

${ }^{619}$ See 3.4, p. 91.
} 
(731).

At first glance, the link between intoxication and disease discussed above dialogically opposes the association of intoxication with heightened life presented in texts by Novalis, Schopenhauer and Freud. Novalis, for example, claims: "Reiz ist vermehrtes Dasein - Erhöhung und Vermehrung der sinnlich unterscheidbaren Wircksamkeit"; 620 Schopenhauer objects to intoxication because "[er] die Energie des Willens steigert", ${ }^{621}$ and Freud's experience of cocaine made him feel more vital ("lebenskräftiger"). ${ }^{622}$ However, this heightened life is compatible with disease if life and disease are regarded as relative concepts. As we have seen, the sanatorium patients' desire for intoxication is not an attempt to enhance life, but rather to redress failing life powers. ${ }^{623}$ The diseased desire to substitute a lack of life energy is most clearly illustrated in Der Zauberberg by Peeperkorn, who compensates his failing strength with "Rausch und Erhebungsmittel, stimulantia, wie man sagt" (857). The quinine beside Peeperkorn's bed is thus a "Rauschmittel" (873) and "Belebungsmittel" (873), yet the effects of this medicine are proportionate to Peeperkorn's chronic illness. Similarly, Frau Magnus's claim after drinking champagne to feel "wie Leben sie durchrinne" (862) expresses a heightened sensitivity that is nevertheless relative to her general weakness (she recently fainted (850)).

Peeperkorn and Frau Magnus's belief that intoxication equals life, together with the influence of disease on their experience, corresponds referentially and selectively to the following passage from Nietzsche's Morgenröte: "Der Rausch gilt [dem dekadenten Menschen] [...] als das wahre Leben". ${ }^{624}$ Moreover, "jene Schwärmer" ${ }^{25}$ accused by Nietzsche of propagating this decadent belief are clearly embodied in Der Zauberberg by Peeperkorn, who leads a group of patients through a long night of drunken revelry (847-

\footnotetext{
${ }^{620}$ Novalis 3, p. 656.

${ }^{621}$ Schopenhauer III, p. 626.

${ }^{622}$ Freud. "Über Coca" (1884). Centralblatt für die gesammte Therapie, vol. 2, pp. 289-314, here, p. 301. http://vlp.mpiwg-berlin.mpg.de/library/data/lit29488/index html?pn=13\&ws=1.5; online resource accessed 2 April 2013. The properties of cocaine are also mentioned in Freud I, pp. 466-67.

${ }^{623}$ See 3.1, pp. 72-73.

${ }^{624}$ Nietzsche KSA 3, p. 54.

625 Ibid., p. 55. This figure combines Nietzsche's ascetic priest, holding sway over the sick masses, with Wagner-as-decadent from Der Fall Wagner.
} 
65). ${ }^{626}$ In a subsequent passage from Morgenröte, Nietzsche reveals the true position of intoxication in opposition to life: "Die Völker werden so sehr betrogen, weil sie immer einen Betrüger suchen, nämlich einen aufregenden Wein für ihre Sinne. Wenn sie nur den haben können, dann nehmen sie wohl mit schlechtem Brode fürlieb. Der Rausch gilt ihnen mehr, als die Nahrung". ${ }^{627}$ The text of Der Zauberberg modifies the opposition of intoxication and nourishment in this passage while appropriating its reference to bread. Accordingly, Peeperkorn tacitly equates food with intoxication by consuming rich food that stimulates the senses, and his habit of calling schnapps "Brot" $(834,862)$ indicates that for him, alcohol is essential life-giving nourishment (at every opportunity, Peeperkorn "labt sich mit einem Schnapps" [827]). Peeperkorn thus intensifies the decadent situation described by Nietzsche to the point that nourishment has become merely another form of intoxication, i.e. to the point that life has become completely perverted by decadence.

The intertextual relationship between sanatorium life and Nietzsche's critique of decadence continues in the chapter section "Herr Albin". ${ }^{628}$ Reclining on his private balcony during one of the rest cure periods, Castorp hears a commotion in the common solarium beneath him, and becomes aware of a group of ladies pleading with Herr Albin to put away the dangerously sharp knife with which he has apparently been playing. Albin further increases these ladies' hysteria by going to fetch his revolver, whereupon he declares that he is prepared to use it should life at the sanatorium become "zu langweilig" (123). Joachim (who also overhears this scene) later refers to Albin's antics as "Unterhaltung" (126); and indeed, the screams, protests and sobbing (121-24) that punctuate Albin's declarations indicate that his audience is far from bored. The entertainment presented by Herr Albin is easily identifiable according to Nietzsche's description of Wagner as "ein[en] ganz grosse[n] Schauspieler": ${ }^{29}$ Albin has assumed the

\footnotetext{
${ }^{626}$ See above, pp. 121-22. This revelry is punctuated by protein-rich snacks (meat of many kinds; an omelette $(850-51,852)$ in an ironic reference to the dependence of life on protein (404).

${ }^{627}$ Nietzsche KSA 3, p. 161.

${ }^{628}$ The irony inherent in Herr Albin's portrayal is evident from his name, which is a pun on the German word "albern" ("silly").

${ }^{629}$ Nietzsche KSA 6, p. 29. Peeperkorn is also described in theatrical terms in allusion to both Wagner and Gerhart Hauptmann (see H. Kurzke, op. cit., p. 211): “[D]as Schauspiel seiner großen Miene, sein[] blaße[r] Blick unter dem monumentalen Faltenwerk seiner Stirne, [...] die Eindringlichkeit seiner Pantomimik" (850).
} 
role of an actor performing a sketch about suicide on the stage of the common solarium. ${ }^{630}$ The analogy of the stage also suggests a loss of authenticity, i.e. that real life has become substituted by empty gesture. Thus, Albin's performance also recalls Wagner's alleged obsession with effect ("er will die Wirkung, er will Nichts als die Wirkung”), ${ }^{631}$ as well as Nietzsche's disgust at the decadent (Wagnerian) tendency to render authenticity redundant. ${ }^{632}$

In the chapter section "Herr Albin", metatextual links to Nietzsche's critique of Wagner discussed above interrelate with connections to Nietzsche's ascetic priest and to Freud's reflections on contemporary attitudes towards death. Herr Albin thus combines the drama of Wagner with the ascetic priest's function to embody the hopes and fears of his diseased flock. ${ }^{633}$ These hopes take the form of the audience's craving for life stimulus. By confronting the audience with death, for example, Albin's performance enables them to experience meaning in life ${ }^{634}$ - albeit vicariously. This links the affirmation of Nietzsche's view of Wagner and his concept of the ascetic priest in the novel (see above) to Freud's belief that the richness of life forfeited by death's repression is substituted by art. ${ }^{635}$ Herr Albin also embodies the fears of his audience by presenting the ladies in the common solarium with the spectre of death. His boast that suicide is "eine glatte Sache" (124) is intensely shocking to those who are conditioned to shy away from the subject. ${ }^{636}$ On the other hand, this shock is an example of the extreme emotion to which these decadent, indirectly asthenic ladies are attracted, and their hysteria thus reflects the crazed enthusiasm of the Wagnerian. ${ }^{637}$ Their shrieks and groans after each of Albin's utterances also recall

\footnotetext{
${ }^{630}$ The curtain raised by Castorp's eavesdropping is lowered again by a voice commanding silence: "Dann ward es still in der Liegehalle, so still, als sei ein Traum oder Spuk zerstoben" (125). This scene thus also clearly recalls Shakespeare's A Midsummer Night's Dream, and Albin the character of Bottom.

${ }^{631}$ Nietzsche KSA 6, p. 31.

${ }^{632}$ Ibid., p. 37. Nietzsche also describes Wagner's music as “niemals wahr” (ibid., p. 31) and as “[die] Kunst zu lügen" (ibid., p. 39).

${ }^{633}$ Nietzsche KSA 5, p. 366. Nietzsche actually links Wagner to the ascetic priest in Der Fall Wagner (Nietzsche KSA 6, p. 44). See the discussion of Peeperkorn above.

${ }^{634}$ See 4.2, p. 111.

${ }^{635}$ Freud X, p. 343.

${ }^{636}$ See 2.1, pp. 23-24.

${ }^{637}$ Nietzsche KSA 6, p. 36.
} 
the effect of Nietzsche's ascetic priest by suggesting the fervent (and enthusiastic) responses of a Gospel choir to the words of their Minister. ${ }^{638}$ By relating Nietzsche's Wagner critique and figure of the ascetic priest to ideas from the work of Freud, this chapter section encourages the reader to interpret the sanatorium patients' indirectly asthenic, decadent craving for entertainment as specific to the pre-war society depicted in the novel.

At the beginning of 4.2, I established via intertextual connections in Der Zauberberg to the work of Novalis and Nietzsche that excessive stimulus causes lethargy. ${ }^{639}$ This can also be seen in the context of entertainment. In the chapter section "Herr Albin", for example, Joachim criticises Albin on the grounds that the ladies' extreme excitement will set them "um Wochen zurück" (126). Similarly, the portrayal of agitated life ("in aufspringender, zappelnd verweilender und wegzuckender Unruhe" [479]) that delights the tubercular cinema audience ultimately creates "ein Gefühl der Ohnmacht" (482). ${ }^{640}$ Both entertainment and intoxicating substances exhaust the already weak sanatorium patients. This is illustrated by Peeperkorn's attempt to substitute his lack of energy with stimulants, a vicious circle in which his consumption of rich food, coffee, and alcohol actually saps his strength. The sequence of stimulus (entertainment, intoxication) followed by exhaustion in Der Zauberberg selectively parallels Novalis's following claim: "Alle Zerstreuung schwächt [...] [und] entkräftet". ${ }^{641}$ Nietzsche similarly declares: "Wagner wirkt wie ein fortgesetzter Gebrauch von Alkohol. Er stumpft ab, er verschleimt den Magen”; 642 “[d]ie Menschen der erhabenen und verzückten Augenblicke [sind elend und trostlos zu Muthe] wegen der verschwenderischen Abnützung ihrer Nervenkräfte". ${ }^{643}$

\footnotetext{
638 This passage also recalls the chorus in Greek tragedy depicted by Nietzsche in Die Geburt der Tragödie aus dem Geiste der Musik (Nietzsche KSA 1, pp. 52-64).

${ }^{639}$ See 4.2, pp. 109-10.

640 See 4.3, pp. 118-19.

${ }^{641}$ Novalis 2, p. 612. Director Behrens' diagnosis of the cause of Castorp's lethargy in the section "Der große Stumpfsinn" also clearly relates to this idea: "Sie [Castorp] sind verhätschelt mit Sensationen, und wenn Ihnen nicht alle Tage was Erstklassiges geboten wird, so mucken und muffen Sie über die Sauregurkenzeit." (947)
}

${ }^{642}$ Nietzsche KSA 6, p. 44. This intertext relates to the following passage by Novalis quoted in 4.2 (see p. 110): “Abstumpfung der Sinne. (Gewöhnung, Erschöpfung, Abhärtung etc.)” (Novalis 2, p. 549).

${ }^{643}$ Nietzsche KSA 3, p. 54. Nietzsche's intertext underscores the essential sameness of entertainment and intoxication as sources of stimulus. Nietzsche also notes that extreme emotions exhaust the individual: "[E]in rapider Verbrauch von Nervenkraft, eine krankhafte Steigerung schädlicher Ausleerungen [...] ist damit 
The exhausting effect of sensation explains the Wagnerian's attraction to stimulus. Nietzsche subsequently explains: "Den Erschöpften lockt das Schädliche [...]. Wagner vermehrt die Erschöpfung, deshalb zieht er die Schwachen und Erschöpften an."'644 Similarly, Freud notes in “Die 'kulturelle' Sexualmoral und die moderne Nervosität”: "Die erschlafften Nerven suchen ihre Erholung in gesteigerten Reizen, in stark gewürzten Genüssen, um dadurch noch mehr zu ermüden". ${ }^{645}$ Interpreted according to these texts, the sanatorium patients' attraction to entertainment and intoxicating substances appears to have exacerbated their lethargy and boredom. Peeperkorn's love of stimulants presumably even leads to his death, since these substances accelerate the physical deterioration that prompts him to commit suicide. In addition, the relationship between Novalis's understanding of stimuli and disease and Nietzsche's critique of Wagnerian music in terms of pathological stimulus, i.e. the alignment of biological disease with social decadence, prompts the reader to interpret entertainment and intoxicating substances as characteristic of the decadence of sanatorium society. This link between entertainment, intoxicating substances and social “disease" within Der Zauberberg establishes that the sanatorium patients' lethargy has not only been caused but also aggravated by sociological factors.

\subsection{Irritability and aggression}

The sanatorium patients' lethargy discussed in the previous subchapters is replaced in Der Zauberberg in the chapter section "Die große Gereiztheit" by a chronic state of irritability.

This new fractious mood is summarised by the narrator in the following passage:

Was gab es denn? Was lag in der Luft? - Zanksucht. Kriselnde Gereiztheit. Namenlose Ungeduld. Eine allgemeine Neigung zu giftigem Wortwechsel, zum Wutausbruch, ja zum Handgemenge. Erbitterter Streit, zügelloses Hin- und Hergeschrei entsprang alle Tage zwischen einzelnen und ganzen Gruppen, und das Kennzeichnende war, daß die Nichtbeteiligten, statt von dem Zustande der gerade Ergriffenen abgestoßen zu sein oder sich ins Mittel $\mathrm{zu}$ legen, vielmehr

bedingt" (Nietzsche KSA 6, p 272).

${ }^{644}$ Nietzsche KSA 6, p. 22. In Unzeitgemäße Betrachtungen (1876), Nietzsche claims of Wagner fans: “[S]ie wollen ja nicht Licht, sondern Blendung" (Nietzsche KSA 1, p. 464). This metaphor is also used by Novalis to portray the cause of exhaustion as excessive stimulus: "Indirekte [...] Asthenie [...] entsteht durch Blendung - Übermäßiges Licht” (Novalis 2, p. 620) (this passage is also discussed in 3.3 (see pp. 81-82).

${ }^{645}$ Freud VII, p. 146. 
sympathetischen Anteil daran nahmen und sich dem Taumel innerlich ebenfalls überließen. Man erblaßte und bebte. Die Augen blitzten ausfällig, die Münder verbogen sich leidenschaftlich. Man beneidete die eben Aktiven um das Recht, den Anlaß, zu schreien. Eine zerrende Lust, es ihnen gleichzutun, peinigte Seele und Leib, und wer nicht die Kraft zur Flucht in die Einsamkeit besaß, wurde unrettbar in den Strudel gezogen. (1034-35)

Although the text of Der Zauberberg does not give a reason for the patients' irritated state, the narrator's reference to the widespread irritability as "eine[] Infektion" (1034) suggests that it is pathological. In 4.2, I demonstrated that the sanatorium patients' lethargy is illuminated by Novalis's concept of indirect asthenia as a state of "mangelnder Reitzbarkeit". ${ }^{646}$ Novalis's theoretical fragments also provide an explanation for the sanatorium patients' agitation, which corresponds to "[der] überflüssige[n] Reitzbarkeit" characteristic of direkte Asthenie (direct asthenia). ${ }^{647}$ In Der Zauberberg, both Fräulein Engelhart's feeling of being "innerlich gespannt und rastlos" (71), ${ }^{648}$ and the widespread tension depicted in "Die große Gereiztheit" can thus be interpreted as directly asthenic.

In subchapters 4.2 and 4.4, I revealed strong connections between Novalis's theories of stimulation and Nietzsche's critique of decadence. ${ }^{649}$ This relationship continues in the context of irritability. Whereas a healthy person "reagiert auf alle Art Reize langsam", ${ }^{650}$ Nietzsche criticises decadent modern man for responding to his environment “[mit] Ärger [und] krankhafte[r] Verletzlichkeit". ${ }^{651}$ Nietzsche's theory of decadence also provides insight into the description of the sanatorium patients' irritation as "einer Infektion" (1034), in accordance with Nietzsche's use of the same word to describe the influence of the agitated and agitating music of Wagner. ${ }^{652}$ In 4.2, I established that lethargy is symptomatic of modern, social pathology. ${ }^{653}$ This is also true of irritability: in "Die

\footnotetext{
${ }^{646}$ Novalis 2, p. 573. See 4.2, p. 109.

${ }^{647}$ Novalis 2, p. 573.

${ }^{648}$ See 4.1, p. 108.

${ }^{649}$ See 4.2, p. 110; 4.4, pp. 119-22.

${ }^{650}$ Nietzsche KSA 6, p. 267.

${ }^{651}$ Ibid., p. 272.

${ }^{652}$ Ibid., pp. 22, 44.

${ }^{653}$ See 4.2, p. 110.
} 
'kulturelle' Sexualmoral und die moderne Nervosität', Freud notes that contemporary society is responsible for an increase in cases of anxiety. ${ }^{654}$ Freud's observation is anticipated in Jenseits von Gut und Böse by Nietzsche, who similarly proclaims: "Es giebt heute fast überall in Europa eine krankhafte Empfindlichkeit und Reizbarkeit für Schmerz, insgleichen eine widrige Unenthaltsamkeit in der Klage, eine Verzärtlichung, [...] einen förmlichen Cultus des Leidens." ${ }^{\circ 55}$

The psychological aspect to Freud's and Nietzsche's texts quoted above is reflected in Der Zauberberg by the character of Director Behrens, who reacts anxiously when he chances across Castorp and Joachim in the chapter section "Humaniora" ("[e]r war nervös, sichtlich schrak er zusammen, als er die Vetter bemerkte" [383]). This anxiety is persistent: the narrator reiterates his or her judgement a few pages later by concluding that Behrens is “entschieden [...] nervös” (387). Behrens' anxiety is placed firmly in the realm of mental illness when interpreted according to the following excerpt from Nietzsche's Der Fall Wagner:

Wagner's Kunst ist krank. Die Probleme, die er auf die Bühne bringt - lauter Hysteriker-Probleme -, das Convulsivische seines Affekts, seine überreizte Sensibilität, sein Geschmack, der nach immer schärfern Würzen verlangte, seine Instabilität, die er zu Principien verkleidete, nicht am wenigsten die Wahl seiner Helden und Heldinnen, diese als physiologische Typen betrachtet (- eine KrankenGalerie! -): Alles zusammen stellt ein Krankheitsbild dar, das keinen Zweifel lässt. Wagner est une névrose. ${ }^{656}$

\footnotetext{
${ }^{654}$ Freud VII, pp. 144-45. Nevertheless, Freud rejects contemporary attempts to explain neurasthenia in terms of modern culture in general (ibid., p. 148). Neurasthenia was a $19^{\text {th }}$ century interpretation of Brown's concept of asthenia (W. F. Bynum. "The rise of science and medicine 1850-1913", in The Western Medical Tradition 1800 to 2000. Cambridge: Cambridge University Press, 2006, pp. 111-240, here, pp. 200-201), similarly a nervous disease believed to be brought on by excessive stimulus (I. Jens. "Thomas Mann. Auszeichnung durch Krankheit", in T. Sprecher (ed.). Literatur und Krankheit im Fin-de-Siècle (1890-1914). ThomasMann-Studien, vol. 26. Frankfurt am Main: Vittorio Klostermann Verlag, 2000, pp. 233-51, here, p. 236).

${ }^{655}$ Nietzsche KSA 5, p. 236. Nietzsche's praise of Dionysian insanity as "Neurosen der Gesundheit" in the preface to Die Geburt der Tragödie is ignored in Der Zauberberg in favour of Nietzsche's alternative view that insanity is a "Symptom der Entartung, des Niedergangs, der überspäten Cultur" (Nietzsche KSA 1, p. 16). Nietzsche's reference to "eine[r] widrige[n] Unenthaltsamkeit in der Klage" in the passage quoted above is reflected in Der Zauberberg in the patients' obsession with disease as they eagerly discuss their symptoms, thermometer readings, and prognoses following medical examinations $(70,71,116)$.
}

${ }^{656}$ Nietzsche KSA 6, p. 22. 
Psychological irritability can also be found within Freud's oeuvre in the form of Angstneurose (anxiety neurosis), a nervous condition characterised by "[einer] Steigerung der Schmerzempfindlichkeit" ${ }^{\circ 57}$ and by "allgemeine[r] Reizbarkeit". ${ }^{658}$ The similarities between direct asthenia (Novalis), decadent neurosis (Nietzsche) and anxiety neurosis (Freud) lead the reader to wonder if Nietzsche and Freud might have developed their psychological concepts from direct asthenia after first narrowing its focus. In fact, psychological interpretations of irritability can also be found amongst Novalis's fragments, for example in the following passage, in which Novalis neatly transfers the causes and characteristics of direct asthenia to mental illness: "[Es giebt] eine Unbesonnenheit aus Übermaaß an Selbstreitz [...] [wegen] ein[es] zu zarte[n] Organ[s] [...]. Die Unbesonnenheit aus Übermaaß nennt man Wahnsinn." ${ }^{659}$

Director Behrens' nervousness is also connected to his identity as an artist. The painter of portraits, landscapes and still lives, Behrens looks on in "Humaniora" "[mit] der stolzen Beklommenheit des Künstlers" (388) as Castorp and Joachim view the profusion of art on the walls of his apartment. This artistic sensitivity reflects Novalis's belief that genius is linked to pronounced sensitivity ("Sinn"), ${ }^{660}$ and is as such "[das] Resultat einer krankhaften Konstitution" ${ }^{661}$ Schopenhauer also connects the sensibility of the artist to disease, stating: "[D]as Genie [ist] durch ein Übermaß der Nervenkraft, also der Sensibilität, bedingt”, 662 "der, in welchem der Genius lebt, leidet am meisten", ${ }^{663}$ Nietzsche presents himself in Ecce Homo as the embodiment of this creative, directly asthenic excitability: "[I]n jener tiefen Spannung, zu der die Schwangerschaft den Geist und im Grunde den ganzen Organismus verurteilt, [...] [wirkt] jede Art Reiz von aussen her zu

\footnotetext{
${ }^{657}$ Freud I, p. 324.

658 Ibid., p. 317.

${ }^{659}$ Novalis 2, p. 620. The psychological equivalent of indirect asthenia is conversely caused by "[einem] Mangel an Selbstreitz" indicative of "[eines] zu grobe[n] Organ[s]" (ibid.). Novalis regards this link worthy of closer investigation, and proposes the application of Brown's medical system to psychology (ibid., p. 604; see also Novalis 3, p. 249).

${ }^{660}$ Novalis 3, p. 489; see also Novalis 1, p. 281.

${ }^{661}$ Novalis 2, p. 454. The perfect genius, on the other hand, would posess a balanced constitution (ibid.).

${ }^{662}$ Schopenhauer IV, p. 390; see also Schopenhauer II, p. 502.

663 Schopenhauer I, pp. 425-26.
} 
vehement [...], [schlägt] zu tief [ein]". ${ }^{664}$ In a premonition of his own end, Nietzsche links this nervous sensitivity to insanity in the preface to Die Geburt der Tragödie, ${ }^{665}$ an association that anticipates Freud's claim in the essay "Der Dichter und das Phantasieren" (1908) that the highly developed imaginations of the artist and the psychologically disturbed indicate kinship. ${ }^{666}$ These intertexts by Novalis, Schopenhauer, Nietzsche and Freud explain Director Behrens' anxiety at presenting his paintings as symptomatic of the directly asthenic constitution that actually predisposed him towards art.

Freud's belief that neurosis had become more prevalent in early $20^{\text {th }}$-century society ${ }^{667}$ invites the reader to interpret Director Behrens' malaise in the context of modern culture. In particular, the potential link between irritation and culture is enriched by the reader's knowledge of the following texts by Schopenhauer, Nietzsche and Freud. Schopenhauer believes that human aggression is controlled by society, "[gehalten] in den Schranken der Ordnung [...] und Gesetzlichkeit". ${ }^{668}$ Nietzsche presents a similar argument in Jenseits von Gut und Böse, asserting that civilisation is based on the sublimation of violence: “Fast alles, was wir 'höhere Cultur' nennen, beruht auf der Vergeistigung und Vertiefung der Grausamkeit". ${ }^{69}$ This antithetical relationship between aggression and culture anticipates the psycho-sociological theories of Freud, who claims that the development of culture is predicated on the suppression and diversion of the aggressive drive. ${ }^{670}$ Earlier in this subchapter, I established that the sanatorium patients' "[k]riselnde Gereiztheit" (1034) is a cultural phenomenon symptomatic of decadence. ${ }^{671}$ The opposition of culture and aggression established by Schopenhauer's, Nietzsche's and Freud's texts discussed above consequently suggests that the patients' irritability is essentially unlike

\footnotetext{
${ }^{664}$ Nietzsche KSA 6, p. 284. Thomas Mann credits this "verderblichen Reizungszustand" with leading to Nietzsche's collapse (Mann 19.1, p. 193). Mann also establishes himself as an artistic "type" by noting his own "Reizbarkeit, Dünnhäutigkeit und Wahrnehmungsnervosität” (Mann 13.1, p. 13).

${ }^{665}$ Nietzsche KSA 1, p. 16.

${ }^{666}$ Freud VII, p. 218.

${ }^{667}$ Ibid., pp. 144-45.

668 Schopenhauer V, p. 296.

${ }^{669}$ Nietzsche KSA 5, p. 166.

${ }^{670}$ Freud XIV, pp. 480-81.

${ }^{671}$ See 4.5, pp. 128-30.
} 
true aggression. This supposition is confirmed by analysis of the primary text. In the chapter section "Die große Gereiztheit", for example, a young man throws a tantrum in the dining room because his tea is too cold:

[B]leich saß er dort und schrie, und es galt der Zwergin [der Dienerin], die bei ihm stand. 'Sie lügen!' schrie er mit sich überschlagender Stimme. 'Der Tee ist kalt! Eiskalt ist mein Tee [...]. Ich trinke es nicht! Ich will es nicht!' kreischte er und fing an, mit beiden Fäusten auf den Tische zu trommeln, daß alles Geschirr der Tafel klirrte und tanzte. (1036)

Rather than "natural" brutality, this scene, together with the narrator's description of the general state of irritability quoted earlier, portrays cultural over-refinement in the form of ineffectual and peevish bad temper; childish hair-pulling and scratching rather than bestial bloodlust.

Significantly, true aggression in Der Zauberberg is expressed almost exclusively in a state of unconsciousness. In the chapter section "Satana macht ehrrührige Vorschläge", for example, Castorp reacts in a dream with anger to the presence of Settembrini (“" [f]ort mit Ihnen!"” [141]), and dreams that Herr Miklosich carries Frau Stöhr away in his jaws only to be skewered with a spear by Herr Paravant (141). ${ }^{672}$ This dream aggression can be explained according to the view held by both Nietzsche and Freud that sleep and dreams are remnants of a primitive human state in opposition to culture. ${ }^{673}$ The contrast between Castorp's unconscious aggression and his usual mild manner illustrates this antagonism, and the subsequent description of Castorp's conscious personality as "ein[e] andere[], weniger ungehemmt, als der des Traumes" (228) is a strongly referential allusion to Nietzsche and Freud's shared belief that drives repressed by the conscious compensate by expressing themselves in dreams. ${ }^{674}$ Novalis also notes the psychological importance of dreams (“[d]ie Träume sind für den Psych[ologen] höchstwichtig”), ${ }^{675}$ yet Novalis's view

\footnotetext{
672 Another example of the unconscious expression of aggression occurs in the section "Schnee", in which Castorp dreams of two hags tearing up a child with their bare hands (745).

${ }^{673}$ Nietzsche KSA 2, pp. 31-32; Freud X, pp. 337-38.

${ }^{674}$ Nietzsche KSA 3, p. 112; Freud X, p. 338. See 3.3, p. 88.

675 Novalis 3, p. 356.
} 
of dream function diverges from Nietzsche's and Freud's theories because he considers dreams to enhance rather than oppose culture and civilisation. ${ }^{676}$ In contrast, the disparity between Castorp's dream aggression and his formal, polite behaviour while awake clearly indicates that aggressive acts are censored by the $20^{\text {th }}$-century society to which he belongs.

The repression of aggression within society is also illustrated in Der Zauberberg by the tendency of many characters towards self-denial. Joachim, for example, only confesses his love to the Russian girl Marusja when his disease becomes terminal, i.e. when it is too late (803), Castorp fails to act when his beloved Madame Chauchat returns to the sanatorium in the company of another man (Peeperkorn) (826-39), and Ferdinand Wehsal abases himself by obsessing over a woman who despises him (Chauchat) (932-36). ${ }^{677}$ Selfdenial can be a matter of life and death: the pacifist Settembrini forfeits the possibility of self-defence in a duel by discharging his pistol into the air (1069), and his opponent Naphta shoots himself in the head rather than allow Settembrini this ideological "victory" (1070). ${ }^{678}$ The self-denial portrayed in these passages is explained as a form of aggression towards the self when interpreted according to Nietzsche's conclusion, in Jenseits von Gut und Böse, that self-denial is the inward expression of a drive refused outward expression by society: ${ }^{679}$ "Alle Instinkte, welche sich nicht nach Aussen entladen, wenden sich nach Innen". ${ }^{680}$ Nietzsche's ideas appear to have influenced Freud, whose conclusion that repressed aggression finds sublimated expression as guilt ${ }^{681}$ is arguably based on Nietzsche's reference to guilt as "rückwärts gewendete[] Grausamkeit" ${ }^{62}$ Yet feelings of guilt are conspicuously absent in Der Zauberberg, one exception being Frau Gerngroß's

\footnotetext{
${ }^{676}$ Ibid. See also Heinrich von Ofterdingen's prophetic dream of the Romantic ideal (Novalis 1, pp. 195-97).

${ }^{677}$ Wehsal's self-humiliation will be discussed in more detail in 5.4 of this thesis (see pp. 171-75).

678 Although Schopenhauer considers the negation of the individual in the act of suicide "eine vergebliche und törichte Handlung" (Schopenhauer I, p. 542), he praises self-denial as "die[] einzige unmittelbare Äußerung der Freiheit des Willens an sich" (ibid., p. 414). Bad conscience, on the other hand, is the result of the individual Will's knowledge that it is part of the world, i.e. acts of evil are crimes against life/the Will, and therefore also against the self (ibid., p. 497).

${ }^{679}$ Nietzsche KSA 5, p. 166.

${ }^{680}$ Ibid., p. 322.

${ }^{681}$ Freud XIII, p. 383; Freud XIV, p. 497; Freud XVI, pp. 22, 26.

${ }^{682}$ Nietzsche KSA 5, p. 389; see also ibid., pp. 166, 323.
} 
self-blame in the chapter section "Totentanz" (458). ${ }^{683}$ Within the context of the social repression of aggression, this general absence of guilt in the novel dialogically opposes Nietzsche's conviction that decadence is based on Christian morality, i.e. that guilt and modern culture go hand in hand. ${ }^{684}$ Instead, the absence of guilt in Der Zauberberg is consistent with Freud's comparison in "Zeitgemäßes über Krieg und Tod" of primitive man's "ethische[r] Feinfühligkeit" with the (presumed) indifference of modern soldiers to bloodshed. ${ }^{685}$ Although Freud's text contradicts Nietzsche's views on decadence and morality, both texts concern culture. In fact, by focusing the critique of culture on the prewar era, the relation of "Zeitgemäßes über Krieg und Tod" to the primary text functions as a bridge between the decadence theory of Nietzsche and the early $20^{\text {th }}$-century society analysed in Der Zauberberg.

\subsection{The combination of lethargy and irritability}

Director Behrens' nervousness discussed in $4.5^{686}$ alternates with bouts of depression. In the chapter section "Satana", Castorp learns that the sanatorium director "neigt zur Schwermut" (95), a rumour that is confirmed in "Humaniora" when Behrens succumbs to depression in Castorp's presence:

'Ich werde nun melancholisch', sagte er [Behrens] und legte seine riesige Hand über die Augen. 'Sehen Sie, das kommt so über mich. Da habe ich nun Kaffee mit Ihnen getrunken, und es hat mir geschmeckt, und auf einmal kommt es über mich, daß ich melancholisch werde [...].' (404)

Behrens' anxiety and depression reflect the presence of direct and indirect asthenia within one person, following the association of anxiety with irritability, ${ }^{687}$ and depression with listlessness or lethargy. A mixture of directly and indirectly asthenic symptoms is also exhibited by Castorp, whose characteristic lethargy is complemented by a tendency towards

\footnotetext{
${ }^{683}$ See 3.3, p. 85; 3.4, p. 94.

${ }^{684}$ Nietzsche KSA 5, pp. 285-86; Nietzsche KSA 6, pp. 352-53; see also Nietzsche KSA 5, p. 166.

685 Freud X, p. 349.

${ }^{686}$ See 4.5 , pp. 130-32.

${ }^{687}$ See ibid., pp. 129-31.
} 
anxiety: "[Castorp war] etwas ängstlich mit sich [...] und [neigte] von Natur ein wenig zu hypochondrischen Grillen" (121). ${ }^{688}$ In the chapter section "Satana macht ehrrührige Vorschläge", Castorp becomes convinced that the girl seated opposite in the dining room is laughing at him (128), and he reacts hysterically when Frau Stöhr declares her ability to prepare twenty-eight different types of fish sauce: ${ }^{689}$

Das schien dem armen Hans Castorp entsetzlich; er erschrak, griff sich mit der Hand an die Stirn und vergaß vollkommen, einen Bissen Pumpernickel mit Chester, den er im Munde hatte, fertig zu kauen und herunterzuschlucken. Noch als man von Tische aufstand, hatte er ihn im Munde. (129)

Castorp's paranoia and hysteria, like Behrens' anxiety, are tense, irritable states that correspond to direct asthenia.

Although the juxtaposition of indirect and directly asthenic symptoms experienced by Castorp and Director Behrens is not explained by the primary text, the combination of lethargy and tension is well documented in the work of Novalis, Schopenhauer, Nietzsche and Freud. Novalis, for example, describes the dominant contemporary constitution as both exhausted and tense, ${ }^{600}$ and Schopenhauer credits excessive excitability with producing irritable and depressive symptoms ("periodische übermäßige Heiterkeit und verwaltende Melancholie"). ${ }^{691}$ Nietzsche regards both the depressive epidemic caused by social intermarriage ${ }^{692}$ and the modern state of irritability as fundamentally decadent: "Nichts [ist] moderner [...] als diese Gesammterkrankung, diese Spätheit und Überreiztheit der nervösen Maschinerie". ${ }^{693}$ Freud notes a prevalence of anxiety neurosis and "Melancholie"

\footnotetext{
688 The combination of lethargy and tension is wittily illustrated in Der Zauberberg in the chapter section "Satana macht ehrrührige Vorschläge", when Joachim tells Castorp about a patient who committed suicide and the latter "gähnt[] erregt" (127).

${ }^{689}$ Castorp also reacts to the prevalence of death at the sanatorium with hysteria (81) (see 2.1, pp. 21-23), and Frau Stöhr herself falls victim to "Anfälle[n] von feiger und weinerlicher Besorgnis" (452-53), alternating between sobbing and airing paranoid suspicions about Director Behrens' diagnosis.

690 "Brown ist der Arzt unsrer Zeit. Die herrschende Konstitution ist die Zärtliche - die Asthenische" (Novalis 2, p. 604). Novalis links this prevalence of disease to civilisation: "Die Vermehrung von Kr[ankheiten] [sind] Zeichen der höhern Kultur" (Novalis 3, p. 349).

${ }^{691}$ Schopenhauer IV, p. 390; see also Schopenhauer II, p. 502.

692 Nietzsche KSA 5, p. 378.

${ }^{693}$ Nietzsche KSA 6, p. 23.
} 
in combination. ${ }^{694}$ Moreover, the decadent combination of tension and lethargy in Der Zauberberg also reflects Schopenhauer's description of human life torn between pain and boredom. ${ }^{695}$

In contrast to the combined symptoms of lethargy and tension exhibited by Director Behrens and Castorp, the irritability of the sanatorium patients in the chapter section "Die große Gereiztheit" displaces their previous lethargy. This sequence of lethargy followed by tension is explained by a fragment from the "Teplitzer Fragmente", in which Novalis considers that prolonged exposure to stimuli can cause the indirectly asthenic patient to become directly asthenic: "Über die eigentliche Schwächung durch Debauchen. Durch viele [sic] ind[irecte] Asth[enie] entsteht endlich - direct asthenische Disposition." Unfortunately, Novalis's expositions on Brown's medical system lack consistency; in another fragment, Novalis declares that indirect asthenia leads to the development of direct sthenia (mania). ${ }^{697}$ It seems that Novalis's initial belief that indirect asthenia can lead to direct asthenia is based on Brown's definition of both forms of asthenia as states of weakness, ${ }^{698}$ whereas Novalis's later conclusion is based on his grouping of direct and indirect sthenia (Brown's system does not include the latter) and direct and indirect asthenia symmetrically into pairs. ${ }^{699}$ The text of Der Zauberberg appears to follow Novalis's initial reasoning: the patients' irritability portrayed in the chapter section "Die große Gereiztheit" does not resemble sthenia yet corresponds exactly to direct asthenia. Interpreted according to Novalis's Brownian sequence of lethargy followed by tension, the sanatorium patients' irritation has been caused by their addiction to stimulation. ${ }^{700}$ This interpretation is

\footnotetext{
${ }^{694}$ Freud I, p. 339.

${ }^{695}$ Schopenhauer I, p. 432.

696 Novalis 2, p. 612.

${ }^{697}$ Novalis 3, p. 657.

698 T. H. Broman. The Transformation of German Academic Medicine, 1750-1820. Cambridge: Cambridge University Press, 2002, p. 144 (footnote 40).

${ }^{699}$ Whereas Brown's medical system defines sthenia and asthenia as conditions characterised by pathological stimulation and excitability respectively, Novalis appears to have been influenced by the interpretation of Brown's system by Andreas Röschlaub, who divides excitability into receptive and active factors (see N. Tsouyopoulos. "The Influence of John Brown's Ideas in Germany", in Medical History, vol. 32, supplement no. 8. Cambridge: Cambridge University Press, 1988, pp. 63-74, here, pp. 70-71.

${ }^{700}$ See 4.4, pp. 119-28.
} 
strengthened by the reader's knowledge that Novalis believed (directly asthenic) irritability to be inversely proportional to an organism's capacity for absorbing stimuli: “Je geringer die Capacitaet ist, desto schneller die Wirkung des Reitzes - desto empfindlicher der Stoff oder das Erregbare - (desto leichter entzündbar.)"701 This text suggests that the sanatorium patients' nerves have been sensitised following the decrease in capacity associated with their indirectly asthenic exhaustion, an idea concordant with both Nietzsche's concept of decadence as heightened mental activity consequent to decreased life force and Freud's theory of neurosis caused by the repression of drives. ${ }^{702}$ Furthermore, the position of the sequence of lethargy in "Der große Stumpfsinn" and irritability in "Die große Gereiztheit" immediately before the portrayal of the outbreak of war suggests that these moods and the order in which they occur are intended to reflect the psychology of the European population immediately prior to World War I. ${ }^{703}$

A spate of aggressive outbursts in "Die große Gereiztheit" anticipate the scene of war in the final chapter section "Der Donnerschlag". The anti-Semitic taunts of Herr Wiedemann, for example, lead to a brawl with Herr Sonnenschein, during which the two men "traten, stießen, zerrten, hieben und schäumten" (1038). A few pages later, Naphta shoots himself in the head after challenging Settembrini to a duel (1057-70). The release of aggression in this chapter section corresponds selectively to Freud's belief that in exceptional circumstances, cultural values are suspended and aggression regains its natural dominance: "Wo die Gemeinschaft den Vorwurf aufhebt, hört auch die Unterdrückung der bösen Gelüste auf, und die Menschen begehen Taten von Grausamkeit, Tücke, Verrat und Roheit, deren Möglichkeit man mit ihrem kulturellen Niveau für unvereinbar gehalten hätte."704 Indeed, the escalation of violence in Der Zauberberg culminates in the narrator's prediction of the death of several thousand soldiers within a few hours (1082). War's dissolution of culture is recognised by Castorp in the chapter section "Noch jemand" (571-

\footnotetext{
${ }^{701}$ Novalis 2, p. 555.

702 Freud VII, pp. 144-45. See 3.4, pp. 91-92.

703 In Betrachtungen eines Unpolitischen, Thomas Mann notes this pre-war mood as "eine besondere Zugespitztheit, Empfindlichkeit, Verletzlichkeit” (Mann 13.1, p. 17).

${ }^{704}$ Freud X, p. 330.
} 
72). ${ }^{705}$ This antithesis of aggression and culture, together with the position of the outbreak of war in "Der Donnerschlag" after the portrayals of decadent lethargy, irritability and aggression, suggests that war is the natural conclusion to the self-destruction of decadent society.

However, the role of war in the dissolution of culture also relates to texts by Novalis and Nietzsche that present conflict positively as an agent of cultural change. In the essay "Die Christenheit oder Europa", for example, Novalis describes war as "eine neue Regung des bisher schlummernden Europa", ${ }^{706}$ and in Menschliches, Allzumenschliches, Nietzsche credits war with the ability to lend civilisation "neue[] Kraft": 707

[E]ine solche hoch cultivierte und daher nothwendig matte Menschheit, wie die der jetzigen Europäer, nicht nur der Kriege, sondern der grössten und furchtbarsten Kriege - also zeitweiliger Rückfälle in die Barbarei - bedarf, um nicht an den Mitteln der Cultur ihre Cultur und ihr Dasein selber einzubüssen. ${ }^{708}$

The positive message of these texts by Novalis and Nietzsche is dialogically opposed in Der Zauberberg by Naphta's negative adoption of Nietzschean barbarism. Naphta's claim that fear of "Reaktion" is an impediment to progress (611), for example, is linked to his praise of terror and chaos as a means by which to attain social change (580). ${ }^{709}$ This reflects his position as representative of the terrorism and irrationalism rife in European society by 1924. ${ }^{710}$ Another unconvincing argument in favour of war is made in Der Zauberberg by

\footnotetext{
${ }^{705}$ In the speech "Von deutscher Republik", Thomas Mann reiterates this idea that war is the antithesis of culture (Mann 15.1, pp. 519-20). Mann describes war furthermore as essentially Romantic: "Krieg ist Romantik. Niemand hat je das mystisch-poetische Element geleugnet, das ihm innewohnt." (ibid., p. 519)

${ }^{706}$ Novalis 3, p. 522.

${ }^{707}$ Nietzsche KSA 2, p. 312.

${ }^{708}$ Ibid., p. 312; see also ibid., p. 289; Nietzsche KSA 6, p. 274; Nietzsche KSA 13, p. 238. Thomas Mann's knowledge of these texts is evident in the essay "Nietzsche's Philosophie im Lichte unserer Erfahrung" (Mann 19.1, p. 216), in which Mann analyses the exploitation of Nietzsche's ideas on war by the German National Socialists (ibid., pp. 211-13).

${ }^{709}$ See 2.4, p. 48. Thomas Mann criticises the concept of "Reaktion als Revolution" in "Die Stellung Freuds in der modernen Geistesgeschichte" (P. Mendelssohn (ed.). Thomas Mann. Gesammelte Werke in Einzelbänden. Leiden und Größe der Meister, op. cit., p. 896).

${ }^{710}$ H. Mayer. “Thomas Manns 'Zauberberg' als Roman der Weimarer Republik”, in H. Mayer (ed.). Ansichten von Deutschland. Bürgerliches Heldenlesen. Frankfurt am Main: Suhrkamp Verlag, 1988, pp. 89-113, here, pp. 107-109.
} 
Settembrini, whose pacifistic stance ("[m]an glaubt an das Kommen des Krieges, wenn man ihn nicht hinlänglich verabscheut!" [575]) is negated by his praise of war in the service of civilisation:

'[D]er Krieg [...] hat schon dem Fortschritt dienen müssen, wie Sie mir einräumen werden, [...] wenn Sie sich der Kreuzzüge erinnern! Diese Zivilisationskriege haben die Beziehungen der Völker im wirtschaftlichen und handelspolitischen Verkehr aufs glücklichste begünstigt und die abendländische Menschheit im Zeichen einer Idee vereinigt.' (578-79; see also 1076-77)

Although this argument does little to convince the reader of the merits of war, more credible support for the message of the intertexts can be found in the chapter section "Der Donnerschlag". Here, Castorp's release from the spell of the sanatorium by the outbreak of war is described in terms of redemption: "Er [Castorp] zog die Beine unter sich, stand auf, blickte um sich. Er sah sich entzaubert, erlöst, befreit" (1079). Castorp's plunge into war consequently relates to the following aphorism from Nietzsche's Jenseits von Gut und Böse: “[E]in höherer Mensch, in dem die Lösung eines Problems schläft, [kommt] noch zur rechten Zeit zum Handeln [...] - 'zum Ausbruch'”. ${ }^{711}$ This person is spurred to action by coincidence, “jene[m] Zufall, der die 'Erlaubniss' zum Handeln giebt”. ${ }^{712}$ Similarly, Castorp's release into war is not his own decision but the result of external influences (1079). These links between Castorp and Nietzsche's superior man are complemented by the narrator's reference to Castorp as neither intelligent nor stupid (53), ${ }^{713}$ which selectively recalls Novalis's musings on a future novel that would portray Christ as a "mittelmäßige[r] Kopf'. ${ }^{714}$ Nietzsche's and Novalis's texts in combination suggest that Castorp is a figure of leadership possibly intended to provide orientation for the post-war reader. ${ }^{715}$ This positive view of Castorp tempers the negative interpretation of the novel presented in

\footnotetext{
${ }^{711}$ Nietzsche KSA 5, p. 227.

712 Ibid., pp. 227-28.

${ }^{713}$ See also 3.5 , p. 102.

714 Novalis 3, p. 682.

715 This interpretation of Castorp and his educative role supports the view of Der Zauberberg as a Bildungsroman (see, for example, H. Koopmann. "Philosophischer Roman oder romanhafte Philosophie? Zu Thomas Manns Lebensphilosophischer Orientierung in den zwanziger Jahren”, op. cit., p. 70 ; H. Kurzke, op. cit., p. 209).
} 
chapter two of this thesis, and consequently gives some weight to the narrator's ultimate hope: "Wird auch aus diesem Weltfest des Todes [...] einmal die Liebe wieder steigen?" (1085) To the reader who has knowledge of the entire web of intertexts discussed in the present subchapter, these lines express tentative hope for European society in general after the cultural destruction inherent to World War I, ${ }^{716}$ a hope underscored politically by the establishment of the Weimar Republic in $1919 .{ }^{717}$

\subsection{Conclusion}

In the present chapter I have demonstrated that the lethargy and tension portrayed in Der Zauberberg parallel Novalis's concepts of direct and indirect asthenia, which in turn relate to Schopenhauer's view of mental illness, to Nietzsche's theories of decadence and decadent neurosis, and to Freud's views on psychological disorder and society. Influenced by these intertexts, the lethargy and tension depicted in the novel appear symptomatic of a pathological state of contemporary society. The intertextuality of the novel enables the reader to interpret the position of the chapter sections "Der große Stumpfsinn" and "Die große Gereiztheit" immediately before the final section and its portrayal of the outbreak of World War I as indicative of the development of this social pathology. Decadence thus leads to the complete breakdown of culture in war, yet this knowledge is softened by intertextual connections to the work of Novalis and Nietzsche that suggest that the destruction of war may lead to social renewal that, in the sociological context of Der Zauberberg, was partially realised in Germany via the political shift of 1919 from a Monarchy to the Weimar Republic.

\footnotetext{
716 Thomas Mann writes in the preface to the Betrachtungen eines Unpolitischen of the importance of "feste[r] Pfeiler[]" admidst the chaos of post-war Europe (Mann 13.1, p. 16).

${ }^{717}$ See J. Bade. "The Magic Mountain of Weimar Politics: the Impact of the Assassination of Walther Rathenau on Thomas Mann's Der Zauberberg”, op. cit., p. 47.
} 


\section{Chapter 5. Life, Eros, death and disease}

\subsection{Life, Eros and aesthetics}

The previous two chapters of this thesis linked life to the response of an organism to stimuli, and disease to the dysfunction of this receptivity. Focusing primarily on the chapter sections "Forschungen" and "Humaniora" from chapter five of Der Zauberberg, the present chapter expands this line of thought by relating the constellation of life, death and disease to Eros, with an initial focus on the interrelation of gender and aesthetics within the conception of life.

In the chapter section "Forschungen", Castorp's study of biology and anatomy establishes that life is a phenomenon borne by matter (419), "[ein] Wuchern, Sichentfalten und Gestaltbilden von etwas Gedunsenem aus Wasser, Eiweiß, Salz und Fetten, welches man nannte" (418). Castorp's reading thus relates metatextually to Novalis's following claim: "In der Materie selbst liegt der Grund des Lebens". ${ }^{718}$ This material basis to life is interpreted in "Forschungen" as human flesh when a vision of life appears before Castorp as he lies dozing on his balcony. Thus, "[d]as Hochgebild organischen Lebens" (588) is the human body, in clear metatextual affirmation of Schopenhauer's conception of the body as the primary reflection of the Will to live, its "unmittelbares Objekt". 719

Castorp's vision of the body appears towards the end of "Forschungen", and the chapter section concludes as this vision leans in for an embrace:

Sie neigte sich ihm, neigte sich zu ihm, über ihn, er spürte ihren organischen Duft, spürte den Spitzenstoß ihres Herzens. Heiße Zartheit umschlang seinen Hals, und während er, vergehend vor Lust und Grauen, seine Hände an ihre äußeren Oberarme legte, dorthin, wo die den Triceps überspannende, körnige Haut von wonniger Kühle war, fühlte er auf seinen Lippen die feuchte Ansaugung ihres Kusses. (434)

Although Castorp's fantasy of life as the human body affirms the message of the intertexts

\footnotetext{
718 Novalis 3, p. 659.

719 Schopenhauer I, p. 52. Similarly, the human body is "nichts anderes als der objektivierte, d.h. zur Vorstellung gewordene Wille” (ibid., p. 158); “[j]eder wahre, ächte, unmittelbare Akt des Willens ist sofort und unmittelbar auch erscheinender Akt des Leibes: und diesem entsprechend ist andererseits jede Einwirkung auf den Leib sofort und unmittelbar auch Einwirkung auf den Willen" (ibid., p. 158).
} 
discussed above, the gender implied by the pronoun "sie" places this vision in dialogical opposition to Schopenhauer's concept of the Will to live as a masculine force. ${ }^{720}$ The femininity of the living body in "Forschungen" is underscored by life's link to the object of Castorp's desire, Madame Chauchat. Life's textured skin ("körnige Haut" [434]) is clearly reminiscent of the following depiction of Chauchat's portrait: "[Der Künstler] hatte sich des körnigen Charakters der Leinwand bedient, um ihn [...] durch die Ölfarbe hindurch als natürliche Unebenheit der Hautoberfläche wirken zu lassen" (392). ${ }^{721}$ The representation of life by the female body is confirmed in the chapter section "Vingt et un" when Mynheer Peeperkorn declares to Castorp: "Das Leben - junger Mann - es ist ein Weib" (855). The boldness and form of this statement allows the reader to trace its metatextual connection to the aphorism "vita femina" from Die fröhliche Wissenschaft, in which Nietzsche exclaims: "Ja, das Leben ist ein Weib!",722

The female life in this text by Nietzsche is related to a gendered concept of nature. Thus, Nietzsche's view of women as more natural than men ${ }^{723}$ is mirrored in Novalis's belief that nature is "wohl weiblich, Jungfrau und Mutter zugleich". ${ }^{724}$ True to her representation of life, Madame Chauchat also illustrates this nature within woman: her décolletage rendered in oils by Behrens "hat[] viel Natur" (391-92), and the name "Chauchat" translates from the French as "hot cat". Chauchat's feline essence corresponds selectively to a passage from Jenseits von Gut und Böse, in which Nietzsche waxes lyrical

\footnotetext{
${ }^{720}$ G. J. Seidel. Knowledge as Sexual Metaphor. Susquehann: Susquehann University Press, 2000, p. 162. Schopenhauer believes that, whereas the child inherits his or her intellect from the mother, his or her Will is inherited from the father (Schopenhauer I, pp. 660-61; Schopenhauer II, p. 695).

${ }^{721}$ Chauchat's skin in this portrait is further associated with Castorp's vision of life when the suggestion of sweat on her painted décolletage is described as "den unsichtbaren Lebensdunst [d]es Fleisches" (392).

${ }^{722}$ Nietzsche KSA 3, p. 569.

${ }^{723}$ Nietzsche KSA 5, p. 178.

${ }^{724}$ Novalis 2, p. 618. This concept of the natural women is complemented by the intellectual character of men, in concordance with the duality of Mind/death and Nature/life discussed in 2.2 (see p. 31). Thus, Thomas Mann suggested to his female translator H. T. Lowe-Porter in a letter of 25 April 1925 that a man might be more suited to the task of translating the intellectually dense passages in Der Zauberberg (Mann 23.1, pp. 153-55). The lack of female intellect is addressed by Novalis (Novalis 2, p. 604), who subsequently claims: "Liebe für die Frauen ist, was Genie für den Mann [ist]" (Novalis 3, p. 489); Schopenhauer similarly regards women as both physically and intellectually inferior to men (Schopenhauer V, p. 720), and Nietzsche believes women incapable of scientific thought (Nietzsche KSA 2, pp. 274-45).
} 
over “die[] gefährliche und schöne Katze 'Weib", 725 This cat-woman's “ächte raubthierhafte listige Geschmeidigkeit" ${ }^{726}$ is also echoed in Der Zauberberg in Chauchat's smooth feline gait "schleichenden Schrittes" (169).

Madame Chauchat's elegance of movement connects her to Eros when interpreted according to Schopenhauer's concept of grace as the temporal representation of the (erotic) Will. ${ }^{727}$ This link between the feline Chauchat and Eros is further related to the erotic representation of nature in texts by Novalis, Schopenhauer, Nietzsche and Freud. ${ }^{728}$ In Der Zauberberg, the interrelation of natural woman, life and Eros is particularly clear from Mynheer Peeperkorn's declaration in the chapter section "Vingt et un": "Das Leben junger Mann - es ist ein Weib, ein hingespreitet Weib, mit dicht beieinander quellenden Brüsten und großer, weicher Bauchfläche zwischen den ausladenden Hüften, mit schmalen Armen und schwellenden Schenkeln und halbgeschlossenen Augen" (855). Peeperkorn's emphasis on hips and breasts indicates that woman's representation of life and Eros is based on her biological function to reproduce. The importance of reproduction for life is also investigated in the chapter section "Forschungen", in which Castorp's biology textbook teaches him that life is "ein Kreislauf von Zeugung zu Zeugung” (421); similarly: "Der Befruchtungsakt, das geschlechtliche Verschmelzen zweier Zellenleiber, stand am Anfange des Aufbaues jedes pluralischen" (421). This view of life relates metatextually to Schopenhauer's theory of reincarnation enabled by reproduction. ${ }^{729}$ In addition, Castorp's reading recalls both Freud's description of procreation in "Jenseits des Lustprinzips" as "eine[] Ureigenschaft der lebenden Materie",730 as well as his consideration that procreation might be a repetition of the origin of life. ${ }^{731}$ Yet Peeperkorn's focus on the female in his view of life and Eros is not reflected by these particular texts by Schopenhauer and Freud. Instead, Peeperkorn's vision appears to reinterpret Schopenhauer's negative

\footnotetext{
${ }^{725}$ Nietzsche KSA 5, p. 178.

726 Ibid.

727 The Will is expressed on the level of the species as libido (Schopenhauer I, p. 316).

${ }^{728}$ Novalis 1, p. 174; Schopenhauer II, p. 518; Nietzsche KSA 6, p. 15; Freud IX, p. 99.

${ }^{729}$ Schopenhauer II, p. 619.

${ }^{730}$ Freud XIII, p. 49.

${ }^{731}$ Ibid., p. 60.
} 
view of women as responsible for the continuation of the species, an idea noted by Nietzsche in his attack of Schopenhauer's philosophy in Zur Genealogie der Moral: "Schopenhauer [hat] [...] die Geschlechtlichkeit in der That als persönlichen Feind behandelt $[\ldots]$ (einbegriffen deren Werkzeug, das Weib, dieses 'instrumentum diaboli')". ${ }^{732}$ This critique of Schopenhauer appears transfigured in its new context within Der Zauberberg as Peeperkorn's affirmation of life-as-woman, which also blends Nietzsche's positive stance towards life with his rather less enthusiastic view of women's primary function to bear children. ${ }^{733}$

According to Novalis and Schopenhauer, the female reproductive role is the basis of her attractiveness to the male. Novalis traces the appeal of a virgin to the premonition of her future motherhood ("d[em] Vorgefühl der Mutterschaft"). ${ }^{734}$ Schopenhauer claims that female attractiveness is proportionate to a woman's ability to produce offspring. ${ }^{735}$ The message of these texts is reinterpreted pragmatically within Der Zauberberg in a link between female attractiveness and the capacity of a woman's body to nourish a foetus. Thus, Peeperkorn's woman of life in the passage quoted earlier is noticeably plump, and in the chapter section "Humaniora", Director Behrens explains sexual attractiveness in terms of the distribution of fat within the female body: "[Es ist] die Fetthaut, die Polsterung, [...] die Unterlage, die mit ihren vielen Fettzellen die holdseligen weiblichen Formen zustande bringt" (393); "[a]m dicksten und fettesten ist es an der weiblichen Brust und am Bauch, an den Oberschenkeln, kurz überall, wo ein bißchen was los ist für Herz und Hand” (397). These passages correspond most selectively and referentially to Schopenhauer's view that, following the instinct to reproduce, the male prefers "eine gewisse Fülle des Fleisches, also ein Vorherrschen der vegetativen Funktion, der Plastizität". ${ }^{736}$ Behrens' subsequent

\footnotetext{
${ }^{732}$ Nietzsche KSA 5, p. 349.

${ }^{733}$ Nietzsche KSA 2, p. 213. It is a woman's “erste[r] und letzte[r] Beruf, kräftige Kinder zu gebären” (Nietzsche KSA 5, p. 177).

734 Novalis 2, p. 618.

735 Schopenhauer II, pp. 654, 694; see also ibid., p. 620. A spinster, in contrast, is "unnutz[]" (Schopenhauer V, p. 731), and "[verfehlt] die eigentliche Bestimmung ihres Geschlechts" (ibid., p. 730 [footnote H]).

736 Schopenhauer II, p. 695. Similarly: "Ein voller weiblicher Busen übt einen ungemeinen Reiz auf das männliche Geschlecht aus: weil er, mit den Propagationsfunktionen des Weibes in direktem Zusammenhange stehend, dem Neugeborenen reichliche Nahrung verspricht." (ibid., p. 695)
} 
deconstruction of female beauty into "Palmetin, Stearin, Oleïn" (396) continues this intertextual relationship to Schopenhauer's philosophy, while also reflecting Novalis's note of "[der] Chemische[n], Organische[n] und Physiologische[n] Natur der Schönheit eines Körpers". ${ }^{737}$ These intertexts reduce female attractiveness to a biological phenomenon in the service of procreation.

However, in comparison to the fecund woman of life described by Peeperkorn, Madame Chauchat appears to lack feminine characteristics. Whereas Peeperkorn's vision of woman has child-bearing hips (855), Chauchat is “nicht breit in den Hüften" (325); life's womanly thighs (855) are contrasted by the long, slim legs of Chauchat (324-25); far from the swelling bosom of life (855), Chauchat's breasts are "klein und mädchenhaft" (325). Schopenhauer deems such a figure revolting ("große Magerkeit [stößt] uns auffallend ab"), ${ }^{738}$ an idea upheld in Der Zauberberg by Director Behrens, who claims that the ancient Greek sculptors "die Nase [...] über ihre [Chauchats] Art von Physiognomie [gerümpft hätten]" (396). Behrens' claim follows Schopenhauer's association of sculpture with life; ${ }^{739}$ Chauchat's figure consequently appears antithetical to the female reproductive function.

Schopenhauer also believes that a well-formed skeleton is essential in a woman, ${ }^{740}$ since: "[I]st [...] das Weib nur ein wenig schief; so kann dies leicht ihrem Sohn einen Puckel aufladen". ${ }^{741}$ In contrast, Madame Chauchat has noticeably bad posture, as the following passage from the chapter section "Analyse" illustrates: "Frau Chauchat saß zusammengesunken und schlaff, ihr Rücken war rund, sie ließ die Schultern nach vorne hängen, und außerdem hielt sie auch noch den Kopf vorgeschoben, so daß der Wirbelknochen im Nackenausschnitt ihrer weißen Bluse hervortrat." (191) Madame Chauchat's protruding vertebrae in this passage are explained by Schopenhauer's text as an indication she may be a poor reproductive specimen. Indeed, Madame Chauchat has no children and appears incapable of having any. In the chapter section "Mein Gott, ich sehe!"', Castorp ruminates that Chauchat may have been rendered infertile by tuberculosis

\footnotetext{
${ }^{737}$ Novalis 3, p. 651.

738 Schopenhauer II, p. 695.

${ }^{739}$ Ibid., pp. 538-39.

${ }^{740}$ Ibid., p. 694.

${ }^{741}$ Ibid., p. 702.
} 
(316), and concludes furthermore that it is "wohl zu spät dafür [Kinder zu bekommen] [...]. Zuweilen, im Profil, scheine Madame Chauchats Gesicht ihm fast schon ein wenig scharf" (316). Measured against Schopenhauer's criteria of attractiveness, Chauchat's disease and age should render her repugnant ("chronische [...] [Krankheiten] schrecken ab"; 742 "ein altes, d.h. nicht mehr menstruiertes Weib erregt unsern Abscheu"). ${ }^{743}$ Yet Thomas Mann saves the credibility of Castorp's attraction to Chauchat with a highly referential allusion to Schopenhauer's claim that women are attractive until the age of twenty-nine. ${ }^{744}$ Accordingly, to Castorp's query whether Chauchat is over thirty, Fräulein Engelhart exclaims: "Clawdia dreißig? Allerschlimmstenfalls sei sie achtundzwanzig" (316).

Nevertheless, Castorp's attraction to the infertile, flat-chested Chauchat essentially defies Schopenhauer's belief, disseminated in Der Zauberberg by Mynheer Peeperkorn and Director Behrens, that men prefer fecund, rotund females. The reader is consequently left to speculate why Castorp finds Chauchat attractive. The answer to this question can be found in her description as "ein junges Mädchen" (118), whose stubby, nibbled-upon fingers remind Castorp of a school-girl's (119). ${ }^{745}$ The motif of the school links Chauchat to Castorp's former class-mate Pribislav Hippe, with whom Castorp was once hopelessly infatuated. ${ }^{746}$ Chauchat is also linked to Hippe by their shared physical characteristics: both woman and boy have slanted eyes, Slavic cheekbones $(140,184)$, and "angenehm heisere Stimme[n]" $(140,187,505$; see also 322). Chauchat is thus revealed to be a variation on a theme, the androgynous replication of a sexually immature male. According to Freud, love for such a male is not the homosexual inversion of normal sexuality, ${ }^{747}$ which reflects a certain failure of the usual developmental pattern from auto-eroticism into object-love, ${ }^{748}$ but the attraction of a bisexual subject for "die Vereinigung beider

\footnotetext{
742 Ibid., p. 694.

743 Ibid.

744 Ibid.

${ }^{745}$ In addition, Chauchat's profile is "von der weichsten Jugendlichkeit" (316).

${ }^{746}$ See 3.3, pp. 85-86.

${ }^{747}$ Freud V, p. 34.

${ }^{748}$ Ibid., pp. 123-31; Freud VII, p. 151; Freud X, p. 138.
} 
Geschlechtscharaktere". ${ }^{749}$ This definition of the immature male can be applied to Madame Chauchat, who, as we saw earlier, lacks pronounced female attributes. In addition, Schopenhauer establishes in Die Welt als Wille und Vorstellung that "Knabenliebe" is antithetical to the heterosexual relationship and its core reproductive function. ${ }^{750}$ The reader's knowledge of this text underscores his or her suspicion that Castorp's attraction to Chauchat is not founded on an interest in life.

In fact, Castorp's infatuation with the androgynous Chauchat is based on his attraction to the opposite of life: death. ${ }^{751}$ Chauchat's charm lies in her aesthetic, Slavic beauty, and aesthetics belongs to the realm of Thanatos. ${ }^{752}$ The metaphysical nature of true beauty is established by Leo Naphta's following claim in the chapter section "Vom Gottesstaat und von übler Erlösung": "Die Schönheit des Leibes ist abstrakt. Wirklichkeit hat nur die innere, die des religiösen Ausdrucks.” (593) The religious essence described in this passage reinterprets Schopenhauer's Will to live as the Christian God (a concept associated with the afterlife and with death), thereby creating a dialogic clash between the intertext's original meaning and its new context. This death-affirming reinterpretation of Schopenhauer's philosophy in Der Zauberberg follows Chauchat's representation of both life (in Castorp's vision) and of life's opposite, aesthetic death, and leads the reader to

\footnotetext{
${ }^{749}$ Freud V, p. 44. Thomas Mann also appears to have been influenced by the 1892 revision of Psychopathia Sexualis, in which Richard Krafft-Ebing argues that the modern individual begins life bisexual and develops heterosexual urges as an adult - adult bisexuality is thus simply a developmental anomaly (S. Angelides. A History of Bisexuality. Chicago: University of Chicago Press, 2001, p. 42).

${ }^{750}$ Schopenhauer II, pp. 718-23. Although Schopenhauer condemns pederasty (homosexual relations between an adult man and a boy) as "eine nicht bloß widernatürliche, sondern auch im höchsten Grade widerwärtige und Abscheu erregende Monstrosität" (ibid., pp. 718-19), he acknowledges its presence "zu allen Zeiten und in allen Ländern" (ibid., p. 720) - Thomas Mann reiterates this idea in the speech "Von deutscher Republik" (Mann 15.1, p. 554). Schopenhauer also explains pederasty as nature's way of protecting the strength of the species: the young and the old produce inferior offspring; better that boys and older men be occupied with one another in sterile relationships (Schopenhauer II, pp. 721-23). In Menschliches, Allzumenschliches, Nietzsche presents Greek pederasty as an educational relationship beneficial to the youth (Nietzsche KSA 2, p. 213).

${ }^{751}$ See 2.4, pp. 44-47.

752 Thomas Mann reiterates this idea in "Von deutscher Republik": “"Was in der Tat ist endgültig schön, außer Tod und Liebe?' Die Frage steht ebendort, und sie schließt die Aussage ein, daß auch die Liebe zur Schönheit, zur Vollkommenheit nichts anderes ist, als Liebe zum Tode" (Mann 15.1, p. 557). The opposition of life/woman and death/aesthetics/man is also explored in Thomas Mann's essay "Die Ehe im Übergang" (Mann 15.1, pp. 1026-44; see also K. Smikalla, op. cit., pp. 153-54). In "Nietzsches Philosophie im Lichte unserer Erfahrung", Thomas Mann similarly proposes an opposition of ethics (life) and aesthetics (death) (Mann 19.1, p. 209).
} 
reason the following: if Castorp's vision of life is Chauchat, yet Chauchat is symbolic of death, then life must be a totality that includes death within it. This conclusion concurs metatextually with Schopenhauer's theory of reincarnation, which positions Eros and death within life. ${ }^{753}$

The opposition of life (flesh) and aesthetics can also be seen in Der Zauberberg in the chapter section "Forschungen", in which the body is portrayed as repulsive:

[Das organische Leben] war nicht geistesgetragen, wie in den Werken der Dichtung und Musik, auch nicht getragen von einem neutralen und geistverzehrten, den Geist auf eine unschuldige Art versinnlichenden Stoff, wie die Form und Schönheit der Bildwerke. Vielmehr war sie getragen und ausgebildet von der auf unbekannte Art zur Wollust erwachten Substanz, der organischen, verwesend-wesenden Materie selbst, dem riechenden Fleische... (419) ${ }^{754}$

Following life's female representation established earlier, this revolting flesh can be interpreted as an essentially feminine substance. Indeed, for both Schopenhauer and Nietzsche, women are completely irreconcilable with art. Schopenhauer believes women to be "unästhetisch[]", ${ }^{755}$ female attractiveness merely an illusion caused by lust; ${ }^{756}$ this intertext suggests that Naphta's dismissal of the abstract nature of physical beauty (see above) is in fact a rejection of the sexual female body (which opposes the male God). Nietzsche similarly opposes the male artist with the natural woman, exclaiming: "Wir Künstler! - Wenn wir ein Weib lieben, so haben wir leicht einen Hass auf die Natur, aller der widerlichen Natürlichkeiten gedenkend, denen jedes Weib ausgesetzt ist". ${ }^{757}$ Knowledge

\footnotetext{
${ }^{753}$ Schopenhauer I, p. 382. This death within life is also related to Nietzsche's discussion of life in Ecce Homo as a unifying whole that embraces disease and suffering (Nietzsche KSA 6, p. 297; see also ibid. pp. 266-67).

754 The differentiation in this passage between partially sexual sculpture and non-sexual poetry and music recalls Schopenhauer's belief that the plastic arts affirm life, whereas painting denies the Will to live (Schopenhauer II, pp. 538-39). This text explains why Behrens declares Chauchat to be a suitable subject for painting ("[Chauchat ist] wohl [...] mehr ein Gegenstand für die Malerei” (396)).

${ }^{755}$ Schopenhauer V, p. 726. Thomas Mann refers to this passage in the speech "Von deutscher Republik": "[D]as Männliche [ist] der reinere und schönere Ausdruck der Idee des Menschen [...]. Sehr Ähnliches äußerte Schopenhauer...” (Mann 15.1, p. 554).

${ }^{756}$ Schopenhauer V, p. 726.

${ }^{757}$ Nietzsche KSA 3, pp. 422-23.
} 
of these texts by Schopenhauer and Nietzsche enables the reader to interpret the natural woman in Der Zauberberg as an object of disgust.

However, a connection between Eros and aesthetics is made in Der Zauberberg when Castorp sees an amalgamation of science and art within the human body (394-95), ${ }^{758}$ i.e. the presence of both biological function and beauty. Castorp's insight clearly indicates a metatextual relationship to Novalis's conception of the body as a mixture of matter and Mind: "Ein organischer Körper gehört in Rücksicht seiner innigen Gemeinschaft - und seines Grundsatzes - Alle für Einen, und Einer für alle - nicht ganz in die Welt - er ist ein gemischtes Produkt." ${ }^{, 759}$ This synthesis within the human body is related in the chapter section "Forschungen" to the discussion of life as a bridge between matter and Mind: ${ }^{760}$ "[Das Leben] war nicht materiell, und es war nicht Geist. Es war etwas zwischen beidem, ein Phänomen, getragen von Materie, gleich dem Regenbogen auf dem Wasserfall und gleich der Flamme" (418). ${ }^{761}$ The position of life between matter and Mind in Der Zauberberg and the corresponding mix of Eros and beauty within the human body elucidate the complexity of Castorp's vision of life, which initially presents itself to him as an artist's model posed before the artist:

\footnotetext{
${ }^{758}$ In contrast, Thomas Mann opposes pleasure, science and art with Christianity (death) in the speech "Von deutscher Republik" (Mann 15.1, p. 542).

${ }^{759}$ Novalis 2, p. 555. Nietzsche also refers to this idea in his description of the sexual male encapsulating "[eine] Nachbarschaft von Gott und Thier" (Nietzsche KSA 3, p. 429). The ambiguity of the body is reflected in Der Zauberberg in the young Castorp's following observation in the presence of his grandfather's dead body:
}

Es hatte mit dem Tode eine fromme, sinnige und traurig schöne, das heißt geistliche Bewandtnis und zugleich eine ganz andere, geradezu gegenteilige, sehr körperliche, sehr materielle, die man weder als schön, noch als sinnig, noch als fromm, noch auch nur als traurig eigentlich ansprechen konnte. (46)

760 This differs subtly from the progression of disease, mind, matter and life discussed in 3.4 of this thesis (see p. 98).

761 This passage closely follows Schopenhauer's description of the species as a rainbow poised over the waterfall of individual lives:

Wie die zerstäubenden Tropfen des tobenden Wasserfalls mit Blitzschnelle wechseln, während der Regenbogen, dessen Träger sie sind, in unbeweglicher Ruhe feststeht, ganz unberührt von jenem rastlosen Wechsel; so bleibt jede Idee, d.i. jede Gattung lebender Wesen ganz unberührt vom fortwährenden Wechsel ihrer Individuen. (Schopenhauer II, p. 617)

This text is also illustrated in Der Zauberberg by the raging waterfall in the chapter section "Mynheer Peeperkorn (Schluß)" (939-40). 
[Es lehnte], die Hände im Nacken verschränkt [...], gestützt auf das eine Bein, so daß der tragende Hüftknochen in seinem Fleische stark hervortrat, während das Knie des schlaffen Beins, leicht abgebogen, bei auf die Zehen gestelltem Fuß sich gegen die Innenseite des belasteten schmiegte. (419)

This exhibitionism is shared by Madame Chauchat, who pauses to be admired by her fellow patients in the chapter section "Politisch verdächtig!":

Frau Chauchat erschien zum Frühstück in einer fließenden Spitzenmatinee mit offenen Ärmeln, worin sie, während die Glastür ins Schloß schmetterte, erst einmal Front machte und sich dem Saal gleichsam anmutig präsentierte, bevor sie sich schleichenden Schrittes zu ihrem Tisch begab [...]. (169)

The aesthetic life suggested by these passages is subtly reconfigured in the chapter section "Forschungen" as a distinct duality of art and Eros within the concept of life. Thus, the "it" that presents itself to Castorp in the posture of the artist's model, “die Hände im Nacken verschränkt" (419), becomes a "she" at the end of the chapter section, "die Hände aus dem Nacken gelöst" (433), no longer an aesthetic object to be admired but a female sexual object that reaches out to embrace Castorp (433-34).

This distinction between art and Eros within life is also reflected in the division of the human body into beautiful and unsavoury components. Settembrini thus limits his affirmation of the body to physical form: "Ich bejahe, ich ehre und liebe den Körper, wie ich die Form, die Schönheit, die Freiheit, die Heiterkeit und den Genuß bejahe, ehre und liebe" (378). Settembrini's words are reminiscent of Schopenhauer's emphasis on form in his theory of aesthetics, ${ }^{762}$ an idea anticipated by Novalis in his contrast between beautiful form and inner repulsiveness ("[w]ie schön ist nicht die Oberfläche des Körpers, wie ekelhaft sein inneres Wesen"). ${ }^{763}$ Nietzsche derides this view: "Das aesthetischBeleidigende am innerlichen Menschen ohne Haut - blutige Massen, Kothgedärme, Eingeweide, alle jene saugenden pumpenden Unthiere - formlos oder häßlich oder grotesk, dazu für den Geruch peinlich. Also weggedacht!"764 However, Settembrini's affirmation of

\footnotetext{
${ }^{762}$ Schopenhauer II, p. 539.

763 Novalis 2, p. 558.

${ }^{764}$ Nietzsche KSA 9, p. 460; see also Nietzsche KSA 3, p. 423.
} 
form is not balanced by an abhorrence of the inner body, but of Eros (99). The consequent antithesis of form and sexuality within the human body is expressed in the chapter section "Forschungen", which presents the idea that the external beauty of the human body exists despite the presence of the sexual component. Thus, flesh "[wurde] zur Form, zum hohen Bilde, zur Schönheit [...], [war] dabei jedoch der Inbegriff der Sinnlichkeit und der Begierde" (418). This passage suggests a metatextual connection to Freud's belief that, whereas the external physical body is aesthetic, the genitals are most definitely not. ${ }^{765}$ Freud's text consequently allows the reader of Der Zauberberg to interpret Settembrini's mixed view of the body as indicating that, whereas external form can be raised to the level of art, the sexual element of the human body is destined to remain abhorrent.

Yet the repulsiveness of Eros is allowed to infect form when the aesthetic within life (Castorp's vision of the artist's model) is portrayed as grotesquely organic even to its skin:

[D]as Bild des Lebens. Es schwebte ihm vor, irgendwo im Raume, entrückt und doch sinnennah, der Leib, der Körper, matt weißlich, ausduftend, dampfend, klebrig, die Haut, in aller Unreinigkeit und Makelhaftigkeit ihrer Natur, mit Flecken, Papillen, Gilbungen, Rissen und körnig-schuppigen Gegenden, überzogen von den zarten Strömen und Wirbeln des rudimentären Lanugoflaums. (419)

The organic skin in this passage is essentially erotic, and thus selectively parallels Freud's

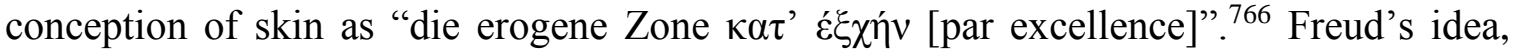
however, contrasts Nietzsche's implicit association of skin with beautiful physical form. ${ }^{767}$ In the light of these intertexts, the skin of the artist's model in the chapter section "Forschungen" appears to demonstrate the presence of Eros within the aesthetic. This further relates the portrayal of skin in Der Zauberberg to texts by Schopenhauer, Freud and Nietzsche that claim aesthetics itself to be a modification of sexuality. Schopenhauer, for example, is convinced that the appreciation of physical beauty is enabled by the intellect's

\footnotetext{
${ }^{765}$ Freud VIII, p. 90.

${ }^{766}$ Freud V, p. 69; see also Freud VIII, p. 46.

${ }^{767}$ See above, p. 152.
} 
separation of Eros from the Will, i.e. the de-sexualisation of the sexual urge. ${ }^{768}$ This idea anticipates Freud's belief that aesthetic beauty is an adaptation of libido, and that the appreciation of art can divert sexual drives "wenn man ihr Interesse von den Genitalien weg auf die Körperbildung im ganzen zu lenken vermag". ${ }^{769}$ Nietzsche acknowledges this erotic component to art in his following attack on Schopenhauer from Also sprach Zarathustra: “Aber nun will euer entmanntes Schielen 'Beschaulichkeit' heissen! Und was mit feigen Augen sich tasten lässt, soll 'schön' getauft werden!"770 The description of skin in Castorp's vision of the artist's model as revolting negatively interprets this erotic basis to the aesthetic. This confirms the message that female Eros is disgusting (see above), while also negating the aesthetic, homosexual realm. Following the association of the female with life and the male with death, this denial of both the feminine and the masculine reveals an ambivalent attitude towards life and death, in which a Romantic affirmation of death is clearly favoured yet is ultimately denied victory over life. ${ }^{771}$

\subsection{The nature of Eros: stimuli and the body}

The sexual nature of the skin discussed above invites the reader to examine the innate connection between Eros and life in the context of Novalis's theory of stimuli. ${ }^{772}$ In chapter three of this thesis, I established that skin symbolises the receptivity of the living organism to stimuli. The interrelation of skin and the erotic consequently suggests that Eros is a form of organic excitability; and indeed, in the chapter section "Vingt et un", Mynheer Peeperkorn links devotion to sensation when he claims that the purpose of life is "die Liebe

768 Thus, Schopenhauer claims:

[D]asselbe, was, wenn es vom Willen unzertrennt bleibt, Geschlechtstrieb mit fein sichtender Auswahl, d.i. Geschlechtsliebe [...] gibt; ebendieses wird, wenn es durch das Vorhandensein eines abnorm überwiegenden Intellekts, sich vom Willen ablöst und doch tätig bleibt, zum objektiven Schönheitssinn für menschliche Gestalt” (Schopenhauer II, p. 539; see also ibid., p. 655).

${ }^{769}$ Freud V, p. 55.

${ }^{770}$ Nietzsche KSA 4, p. 157; see also ibid., p. 156.

771 This interesting tension between life-affirmation and death-affirmation has been connected by several scholars to Thomas Mann's changing political affiliation from support of the monarchy to endorsement of the Weimar Republic (see J. Bade, "The Magic Mountain of Weimar Politics: the Impact of the Assassination of Walther Rathenau on Thomas Mann's Der Zauberberg”, op. cit., p. 47; H. Mayer, op. cit., p. 93).

772 Novalis's theory of stimuli is discussed in chapters three and four of this thesis. 
zum Gefühl” (857). Peeperkorn's obsession with the erotic suggests an equivalence of love and Eros that affirms Novalis's view of both as states of sensitivity ("[g]eheimnißvoller Reitz [ist ein] Element[] der gewöhnlichen Wollust";773 "Liebe ist ein Product der Wechselreitzung 2er Individuen"). ${ }^{774}$ Schopenhauer similarly presents Eros as a state of sensitivity, ${ }^{775}$ and subsequently links this state to love ("alle Verliebtheit, wie ätherisch sie sich auch gebärden mag, wurzelt allein im Geschlechtstriebe”). ${ }^{776}$ Likewise, Freud establishes that lust is a state of excitement ("der Sexualerregung [...] [gleicht] das sexuell Reizende ('die Reize')") 777 that he then equates with love: "Das Wort 'lieben' [...] fixiert sich schließlich an die Sexualobjekte im engeren Sinne und an solche Objekte, welche die Bedürfnisse sublimierter Sexualtriebe befriedigen."778

The sensitivity inherent to both love and lust is analogous to intoxication. ${ }^{779}$ Accordingly, Peeperkorn's fondness for stimulating substances ("'Stützen und Steigerungen der Gefühlskräfte" [857]) reflects a desire to simulate the sensations denied him by his impotence. ${ }^{780}$ Frau Stöhr and Frau Magnus similarly respond with enthusiasm to the erotic stimulation of the little book Die Kunst, zu verführen ("Frau Stöhr [...] fand es 'berauschend'. Frau Magnus [...] pflichtete ihr rückhaltlos bei” (413)). Castorp's infatuation with Madame Chauchat leaves his head filled with flush of feeling ("[einem] süßen Nebel [...], [einem] Rausch" [346]), and thus indicates that intoxication is also consequent to love. This last idea relates metatextually to the work of Schopenhauer,

\footnotetext{
773 Novalis 3, p. 684. Novalis consequently recommends "Reitzende Pflaster zur Stärkung der Geschlechtsth[eile]." (ibid., p. 616) The etymological origins of the word "Wollust" as pleasurable feelings of any kind developed in the middle of the $18^{\text {th }}$ century to include sexual connotations. Thus, Schiller compares Wollust to "himmlisches Genügen" (J. \& W. Grimm. Deutsches Wörterbuch (1854-1961). Trier: Trier Centre for Digital Humanities, 2011. http://woerterbuchnetz.de/DWB/?sigle=DWB\&mode=Vernetzung\&hitlist=\&patternlist=\&lemid=GW2667 1; online resource accessed 12 May 2014), whereas in Novalis's work, "Wollust" has distinctly erotic connotations (ibid.).

${ }^{774}$ Novalis 2, p. 555.

${ }^{775}$ Schopenhauer I, p. 294.

${ }^{776}$ Schopenhauer II, p. 681; see also ibid., pp. 539, 654, 657.

${ }^{777}$ Freud V, p. 55 (footnote 1).

${ }^{778}$ Freud X, p. 230.

${ }^{779}$ Intoxication is also discussed in subchapters 3.4 and 4.4 of this thesis (see pp. 93, 122-28).

${ }^{780}$ See also 4.4, p. 124.
} 
Nietzsche and Freud. According to Schopenhauer, love is "[ein] schwindelnde[s] Entzücken", 781 "eine[] Leidenschaft, die an Heftigkeit jede andere übertrifft" ${ }^{782}$ Nietzsche similarly refers to love as "eine Art Rausch für das gesamte Gefäß-, Nerven- und Muskelsystem". ${ }^{783}$ In addition, Freud notes in Vorlesungen zur Einführung in die Psychoanalyse (1917): “Die Volksseele [...] nennt die Liebe einen 'Rausch' und läßt die Verliebtheit durch Liebestränke entstehen". ${ }^{784}$ Deconstructing the original meaning of this last text, Freud's love potion is interpreted in Der Zauberberg sexually via Director Behrens' tubular coffee grinder, which is decorated with obscene images and described as a device "für alleinstehende Herren" (397). This grinder ironically associates stimulants with the lust within love (see above), thereby transforming the most innocent of beverages into a symbol of erotic stimulus.

In accordance with the essentially stimulating nature of Eros, the distinction of human beings as highly excitable organisms ${ }^{785}$ suggests that humans may be particularly sensitive to erotic stimulus. Indeed, Freud reflects in "Die 'kulturelle' Sexualmoral und die moderne Nervosität" that the human libido is "wahrscheinlich stärker ausgebildet als bei den meisten höheren Tieren", 786 an idea reflected in the description of the human body in the chapter section "Forschungen" as "der Inbegriff der Sinnlichkeit und der Begierde" (418; see also 429). This characterisation of the living body also relates metatextually to Schopenhauer's belief that humans are "konkreter Geschlechtstrieb" ${ }^{787}$ However, Freud's and Schopenhauer's general estimations fail to explain why Castorp's vision of life is female. It seems that erotic sensitivity may be gender specific, a supposition confirmed by analysis of the chapter section "Humaniora", in which Director Behrens' association of fat

\footnotetext{
${ }^{781}$ Schopenhauer II, p. 689.

${ }^{782}$ Ibid., pp. 679-80. Lust is similarly "die heftigste der Begierden, der Wunsch der Wünsche, die Konzentration alles unsers Wollens" (ibid., p. 657).

${ }^{783}$ Nietzsche KSA 13, pp. 526-27; see also ibid., p. 299.

${ }^{784}$ Freud XI, p. 403.

${ }^{785}$ See 3.1, p. 71.

${ }^{786}$ Freud VII, p. 150.

${ }^{787}$ Schopenhauer II, p. 656; see also ibid., p. 657; Schopenhauer I, p. 158.
} 
with the female body ${ }^{788}$ immediately precedes a connection between fat and feeling: "Am dicksten und fettesten ist es an der weiblichen Brust und am Bauch, an den Oberschenkeln, kurz überall, wo ein bißchen was los ist für Herz und Hand. Auch an den Fußsohlen ist es fett und kitzlich." (397) ${ }^{789}$ This characteristic female sensitivity is exemplified by Madame Chauchat. In the chapter section "Humaniora", Castorp stands riveted before Chauchat's portrait with its naked décolletage, and the narrator subsequently notes: "Es war, als ginge unter dem Blick des Betrachters ein kaum merklicher Schauer von Sensitivität über diese Nackheit" (392). ${ }^{790}$ Castorp's gaze in this passage functions as stimulus to which Chauchat's painted flesh reacts, an allocation of masculinity to stimuli which relates metatextually to the view shared by Novalis, Schopenhauer and Freud that desire is a masculine phenomenon. ${ }^{791}$ On the other hand, the sensitivity of Chauchat's décolletage recalls the belief held by both Novalis and Nietzsche that sensuality is characteristic of women. ${ }^{792}$ Novalis evaluates this female excitability negatively, concluding: "Frauen [...] [lieben] oberflächliche Reitze. Sie lieben den Tanz vorzüglich wegen seiner Leichtigkeit, Eitelkeit und Sinnlichkeit". ${ }^{793}$ This view of women is shared by Schopenhauer, who claims: "[A]ls ihren allein ernstlichen Beruf betrachten [Frauen] die Liebe [...] und was damit in Verbindung steht, wie Toilette, Tanz usw". ${ }^{794}$ In addition, Nietzsche declares through the mouthpiece of Zarathustra: "Oberfläche ist des Weibes Gemüth, eine bewegliche

\footnotetext{
${ }^{788}$ See 5.1, p. 146.

${ }^{789}$ The lack of scientific basis for this link between fat and ticklishness sparks the reader's interest, thereby highlighting the alignment of sensitivity with the female.

790 The sensitivity of the body is similarly suggested by Novalis's following fragment on lips and kisses: "Jede sanfte weiche Erhöhung ist ein symbolischer Wunsch der Berührung." (Novalis 2, p. 618) The message of sensuality in this text is reinterpreted ironically in the chapter section "Humaniora" when the narrator ruminates that the painted bosom of Chauchat might exude a living aroma, "wenn man etwa die Lippen darauf drückte" (392).

791 Novalis refers to a duality of "Trieb" (love) and woman (Novalis 2, p. 617); the masculinity of Schopenhauer's Will is underscored by the claim: "Der Coitus ist hauptsächlich die Sache des Mannes" (Schopenhauer V, p. 375); see also Freud V, pp. 120-21.

${ }^{792}$ Novalis 2, p. 613; Nietzsche KSA 10, p. 391 (““d]ie Frauen sind sinnlicher als die Männer”). Nietzsche’s view is reflected in Der Zauberberg in the chapter section "Walpurgisnacht", in which the narrator claims that women are more familiar with passion than the male, "der keineswegs darin zu Hause ist" (504).

${ }^{793}$ Novalis 2, p. 612. Novalis concludes that the excitable female constitution is essentially directly asthenic (ibid., p. 604).

${ }^{794}$ Schopenhauer V, p. 721.
} 
stürmische Haut auf einem seichten Gewässer" ${ }^{795}$ The analogy of skin in Nietzsche's text is reflected in Der Zauberberg in the association of the epidermis with sexual excitability. ${ }^{796}$ Nietzsche's use of this analogy to express contempt for women suggests that women's repellence is based on the erotic sensitivity of their bodies.

The relationship between man and woman, stimuli and sensitivity is explored further in Der Zauberberg in the chapter section "Mynheer Peeperkorn (Des Weiteren)". Peeperkorn defines the male and female erotic roles as follows: "Den Mann berauscht seine Begierde, das Weib verlangt und gewärtigt, von seiner Begierde berauscht zu werden.” (912) This description of the effect of masculine erotic stimulus on the sensitive female reflects and clarifies the relationship between Dr Krokowski and his audience in the chapter section "Analyse". Here, Krokowski's lecture on the power of Eros elicits a striking response from the female sanatorium patients:

Die Lehrerin, Fräulein Engelhart [...], hatte gierige Augen und rotflaumige Flecke auf beide Wangen, - eine Hitze, die sich auf den Gesichtern anderer Damen wiederfand, auch auf dem der Frau Salomon [...] und der Bierbrauersgattin Frau Magnus [...]. Auf Frau Stöhrs Gesicht [...] malte sich eine so ungebildete Schwärmerei, daß es ein Jammer war [...]. (192) ${ }^{797}$

In subchapter 4.4, I discussed the intoxicating effect of Nietzsche's ascetic priest and of Wagnerian music dramas. ${ }^{798}$ The reaction of the female patients to Krokowski in the passage quoted above situates the intoxicating effect of this ascetic priest within the context of Eros, and relates furthermore to the erotic stimulation of Wagner's art (Wagner exploits “die Sinnlichkeit der Musik"; ${ }^{799}$ Wagner is "ein Verführer grossen Stils"). ${ }^{800}$ In addition, the specifically female response to the stimulus of Dr Krokowski is illuminated by

\footnotetext{
795 Nietzsche KSA 4, p. 86.

796 See 5.1, p. 153.

${ }^{797}$ Dr Krokowski's attractiveness to women is also apparent from the female patients' tendency to cluster around him $(130,172)$.

${ }^{798}$ See 4.4, pp. 121-22.

${ }^{799}$ Nietzsche KSA 6, p. 31.

${ }^{800}$ Ibid., p. 42.
} 
Nietzsche's view of Wagner's success, which allegedly rests on the uniquely nervous nature of women: “Der Erfolg Wagner's - sein Erfolg bei den Nerven und folglich bei den Frauen". 801

The sensitivity of women to masculine stimulus in Der Zauberberg also reflects the view held by Novalis, Schopenhauer, Nietzsche and Freud that women are the objects of subjective male desire. ${ }^{802}$ The essentially receptive nature of women is addressed by Novalis in the following fragment on women and flowers: "Pflanzenaehnlichkeit der Weiber. Dichtung auf diese Idee (Blumen sind Gefäße)". ${ }^{803}$ Nietzsche similarly argues in defence of the artist: "[M]an soll vom Künstler, der giebt, nicht verlangen, daß er Weib wird - daß er 'empfängt'". ${ }^{804}$ The message of these texts is affirmed in Der Zauberberg by Peeperkorn, whose view of the sexes Castorp summarises as follows in the chapter section "Mynheer Peeperkorn (Des Weiteren)":

Verzeihen Sie, Mynheer Peeperkorn, daß ich eigenmächtig Ihren Satz beende. [...] Die Frauen, so möchte ich mich ausdrücken, sind reaktive Geschöpfe, ohne selbständige Initiative, lässig im Sinne von passiv... [...]. Die Frau, soweit ich feststellen konnte, betrachtet sich in Liebesangelegenheiten primär durchaus als Objekt, sie läßt es an sich herankommen, sie wählt nicht frei, sie wird zum wählenden Subjekt der Liebe erst auf Grund der Wahl des Mannes, und auch dann noch [...] ist ihre Wahlfreiheit [...] beeinträchtigt und bestochen durch die Tatsache, $d a \beta$ sie gewählt wurde [...]. Sie fragen eine Frau: Liebst du ihn denn? Er liebt mich so sehr! antwortet sie Ihnen mit Augenaufschlag oder auch -niederschlag. (911-12)

The passivity of females expressed in this passage selectively parallels Nietzsche's following aphorism from Menschliches, Allzumenschliches: "Weiber werden aus Liebe ganz zu dem, als was sie in der Vorstellung der Männer, von denen sie geliebt werden,

${ }^{801}$ Ibid., p. 23. Herr Albin's hysterical audience is similarly female (see 4.4, pp. 126-27).

${ }^{802}$ Novalis 2, pp. 617, 618; Schopenhauer II, pp. 697-704; Nietzsche KSA 2, p. 213; Freud VII, p. 158. Schopenhauer's view of women is reflected in the writing of his student Otto Weiniger: "Das Verhältnis von Mann und Weib ist kein anderes als das von Subjekt und Objekt." (O. Weiniger. Geschlecht und Charakter: ein prinzipielle Untersuchung. Munich: Matthes \& Seitz, 1980, p. 391).

${ }^{803}$ Novalis 3, p. 651.

${ }^{804}$ Nietzsche KSA 13, p. 357. Nietzsche believes women to be male possessions (Nietzsche KSA 5, p. 175). 
leben.." ${ }^{\$ 05}$ Here, Nietzsche gives a mellower interpretation of Schopenhauer's view of woman as "seiner Natur nach zum Gehorchen bestimmt", ${ }^{806}$ an opinion tempered further in Freud's acknowledgment that the passivity of women is influenced by both culture and education ${ }^{807}$ Knowledge of these texts enriches the reader's interpretation of Madame Chauchat's decision to sleep with Castorp in the chapter section "Walpurgisnacht". When Castorp asks if he should have approached her earlier, Chauchat replies: "Moi? Tu ne m'échapperas pas, mon petit. Il s'agit de tes intérêts, à toi." (514) (“Ich? Du weichst mir nicht aus, mein Kleiner. Es handelt sich um deine Interessen." [transl. 1092]) Illuminated by the intertexts discussed above, Chauchat's remarkable passivity is transformed into an appropriate female response to masculine desire.

The agency of male desire is underscored by the latter's association with the divine. As Peeperkorn explains to Castorp in the chapter section "Mynheer Peeperkorn (Des Weiteren)":

Unser Gefühl, verstehen Sie, ist die Manneskraft, die das Leben weckt. Das Leben schlummert. Es will geweckt sein zur trunkenen Hochzeit mit dem göttlichen Gefühl. Denn das Gefühl, junger Mann, ist göttlich. Der Mensch ist göttlich, sofern er fühlt. Er ist das Gefühl Gottes. Gott schuf ihn, um durch ihn zu fühlen. Der Mensch ist nichts als das Organ, durch das Gott seine Hochzeit mit dem erweckten und berauschten Leben vollzieht. (913)

The male medium in this passage relates highly referentially to Novalis's "Gottmensch", 808 a human who functions as "das Organ der Gottheit [...], ihre sinnliche Erscheinung" ${ }^{809}$ The sensuality of this mystical medium is reproduced in Der Zauberberg in Castorp's following claim: "[S]obald das Körperliche eine Rolle spielt, wird die Sache mystisch" (883). The metaphysical within the physical in Castorp's statement also relates to further texts by Novalis, for example the seventh "Geistliches Lied", in which Novalis poses the

\footnotetext{
${ }^{805}$ Nietzsche KSA 2, p. 269. In Die fröhliche Wissenschaft, Nietzsche similarly claims: "[D]er Mann macht sich das Bild des Weibes, und das Weib bildet sich nach diesem Bilde" (Nietzsche KSA 3, p. 427).

${ }^{806}$ Schopenhauer V, p. 734; see also ibid., p. 735. Similarly, Nietzsche has a wise man pronounce the following in Die fröhliche Wissenschaft: "Des Mannes Art ist Wille, des Weibes Art Willigkeit, - so ist das Gesetz der Geschlechter" (Nietzsche KSA 3, p. 427).

${ }^{807}$ Freud XV, p. 123.

${ }^{808}$ Novalis 2, p. 443; see also ibid., p. 445.

${ }^{809}$ Ibid., p. 443.
} 
question: "Wer hat des irdischen Leibes / Hohen Sinn errathen?" 810 In a fragment from 1799, Novalis similarly proclaims: "Es giebt nur Einen Tempel in der Welt und das ist der menschliche Körper. Nichts ist heiliger, als diese hohe Gestalt." 811 These ideas anticipate Schopenhauer's view of the body as a medium between Will and world. ${ }^{812}$

The explicitly erotic nature of Peeperkorn's communion with God is also explained by the philosophy of Novalis and Schopenhauer. Novalis, for example, declares in "Poëticismen": "Der Geist [Gott] galvanisirt die Seele [des Menschen] mittelst der gröbern Sinne. Seine Selbstthätigkeit ist Galvanism - Selbstberührung en trois." ${ }^{" 13}$ This text establishes that human sexuality is the medium through which God communicates with the world, and anticipates Schopenhauer's belief that the sexual act is "nicht seine [des Individuums] Sache, sondern die eines Dritten, der erst entstehen soll", 814 i.e. that sexual intercourse between man and woman is initiated by the Will of their unborn child. Both Novalis and Schopenhauer present the idea that erotic relations between men and women consummate a third party's lust; a similar scenario can be found in "Psychoanalytische Bermerkungen über einen autobiographisch beschriebenen Fall von Paranoia (Dementia Paranoides)" (1911), in which Freud discusses the paranoid Dr Daniel Schreber's attempts to satisfy God's erotic demands by sleeping with numerous women. ${ }^{815}$ The third erotic power presented in these texts together with its religious connotations is replicated in Der Zauberberg. Peeperkorn's talk of “[des] Sakrament[s] der Wollust” (894), for example, infers the erotic power of God, while further relating to Novalis's comparison of the holy communion to physical contact ("[i]st die Umarmung nicht etwas dem Abendmahl

\footnotetext{
${ }^{810}$ Novalis 1, pp. 166-68.

${ }^{811}$ Novalis 3, pp. 565-66. Settembrini appears to refer to this passage when he maintains that the human body is "de[r] wahre[] Tempel Gottes" (684); this passage is also quoted by Thomas Mann in the speech "Von deutscher Republik" (Mann 15.1, p. 552).

812 Schopenhauer I, p. 255. Schopenhauer also makes the related claim: "Die Materie [ist] [...] das Verbindungsglied zwischen der Idee und der Erscheinung oder dem einzelnen Ding." (ibid., p. 302)

${ }^{813}$ Novalis 2, p. 545. The penetration of the world by God is also clear from Novalis's fifth "Geistliches Lied", in which Jesus "mit sanftem Zwingen / Alles wird erweichen und durchdringen" (Novalis 1, p. 165).

${ }^{814}$ Schopenhauer II, p. 711.

${ }^{815}$ Freud VIII, p. 268.
} 
Ähnliches"). ${ }^{816}$ This corporeal communion is credited by Novalis with enabling the pious to apprehend "[d]as Geheimniß der Liebe". ${ }^{817}$

Furthermore, Peeperkorn's view of the erotic as divine ("das Gefühl [...] ist göttlich" [913]) reflects Dr Schreber's perception of God's lust as a combination of sunlight, nerves and semen ("Gottesstrahlen"). ${ }^{818}$ Freud relocates God within the individual by interpreting these celestial rays as "die dinglich dargestellten, nach außen projizierten Libidobesetzungen". 819 This internalisation of God is also made by Schopenhauer in his concept of the Will to live; thus for both Schopenhauer and Freud, the creative essence is synonymous with human sexuality. A similar equivalence of God and Eros appears in Der Zauberberg in the following description of the mystical organic body: "Dem scharf dünstenden Dunkel der Achselhöhlen entsprach in mystischem Dreieck die Nacht des Schoßes" (419). The armpits and groin are areas linked to Eros via their description as "intime[] und zärtliche[] Körperstellen" (402). In addition, the allusion to the number three and to mysticism inevitably evokes the holy trinity (as well as Schopenhauer's correlative trio of world, body and Will). The connection of this slightly unsavoury triad of armpits and groin to the divine renders the location of God within the human body ironic; this in turn relates to the primary text's portrayal of the (female) erotic body as disgusting. ${ }^{820}$

Indeed, the repulsiveness of the female body leads to the negation of heterosexual relations in favour of those between the (male) individual and God. In the chapter section "Noch jemand", Naphta declares the bed to be "der Ort der Beiwohnung des Minnenden mit dem Gemeinten [...] zum Zwecke der Beiwohnung mit Gott" (568). This implicitly homosexual communion with God is linked metatextually to Freud's study of Schreber, whose neurotic relationship with the divine allegedly indicated a preference for men. ${ }^{821}$ Yet the inherently female nature of the erotic excitable body poses a problem; Naphta consequently circumvents the body completely by transferring physical lust to the spiritual

\footnotetext{
${ }^{816}$ Novalis 2, p. 596.

${ }^{817}$ Novalis 1, pp. 166-68.

${ }^{818}$ Freud VIII, p. 315.

819 Ibid.

${ }^{820}$ See above, pp. 157-58.

${ }^{821}$ Freud VIII, p. 268.
} 
plane. This process can be seen in the following passage from the chapter section "Operationes spirituales", in which Naphta reveals the true purpose of torture:

[U]nsere wahre Würde beruhte im Geiste, nicht im Fleische, und da die Menschenseele nur zu sehr dazu neigte, ihre ganze Lebenslust aus dem Leibe zu saugen, so waren Schmerzen, die man diesem zufügte, ein durchaus empfehlenswertes Mittel, ihr die Lust am Sinnlichen zu versalzen und sie gleichsam aus dem Fleisch in den Geist zurückzutreiben, damit dieser wieder zur Herrschaft gelange $[\ldots]$... (686)

Naphta's transference of Eros to the mind ironically recalls Nietzsche's view of love as "[der] Vergeistigung der Sinnlichkeit". ${ }^{822}$ In addition, by indicating that the relocation of Eros will enable Mind to gain dominion over the world, the passage quoted above indicates that the death-affirming Last Judgement and Second Coming discussed in $2.6^{823}$ are enabled by Eros. God's might is therefore confirmed as synonymous with lust.

\subsection{Eros, death and disease}

Naphta's displacement of lust to the spiritual plane underscores the nature of love as erotic $^{824}$ by reinterpreting the Christian association of love and death. Nietzsche criticises this link consequent to the veneration of the afterlife in Also sprach Zarathustra: "Lieben und Untergehn: das reimt sich seit Ewigkeiten. Wille zur Liebe: das ist, willig auch sein zum Tode." ${ }^{825}$ In fact, Naphta's dual identity as a Jesuit and a "Wollüstiger" (619; see also 621) corresponds selectively to Novalis's following interpretation of Christianity: "Die Xstliche Religion ist die eigentliche Religion der Wollust". ${ }^{826}$ In Der Zauberberg, this Christian fundament to the combination of Eros and death is illustrated by Dr Krokowski,

\footnotetext{
${ }^{822}$ Nietzsche KSA 6, p. 84.

${ }^{823}$ See 2.6, p. 63.

${ }^{824}$ See 5.2, pp. 154-55.

${ }^{825}$ Nietzsche KSA 4, p. 157; see also Nietzsche KSA 5, pp. 224-25.

${ }^{826}$ Novalis 3, p. 653. In "Von deutscher Republik", Thomas Mann notes the interrelation of Eros and death in Novalis's work: "[N]iemals [ist] eine innigere Verbindung von Krankheit, Tod und Wollust erdichtet worden" (Mann 15.1, p. 556). Mann's understanding of Novalis thus closely follows Brandes' claim that Novalis glorifies the dead, who are "[d]iejenigen [...], welche in allen Freuden der Sinnlichkeit schwelgen" (G. Brandes, op. cit., p. 242).
} 
whose preoccupation with (Freudian) psychoanalysis and the erotic depths of the psyche is revealed to be essentially Catholic when Settembrini denounces the doctor as "[einen] schamlose[n] Beichtvater" (148). This religious motif is further associated with death via Krokowski's black monk's habit and sandals $(73,99,194) .{ }^{827}$ However, the Christian link to Eros and death is revoked in the chapter section "Walpurgisnacht" amid palintextual references to Goethe's Faust (491, 492, 493, 501). These place the Christian Shrovetide festivities in the context of the annual meeting of witches on the Brocken (the highest of the Harz Mountains in Germany). ${ }^{828}$ Quoting Faust with enthusiasm to the literarily naïve Castorp, Settembrini reveals the main protagonists' double link to Eros and death. Frau Stöhr is Baubo, an obscene figure in Greek mythology interpreted in Faust as the queen of the witches (495), Director Behrens is Urian (the devil), observed ladling a love-potion (punch) from a steaming cauldron into his patients' glasses (501), ${ }^{829}$ and Madame Chauchat is Lilith, Adam's first wife (496-97), in Jewish mythology a demon of the night who ensnares men. Chauchat's association with both Eros and death in this heathen context aligns her with Nietzsche's concept of Dionysus, the lusty god of both creation and destruction. ${ }^{830}$

\footnotetext{
${ }^{827}$ See also 2.4, p. 42 (footnote 260). Dr Krokowski's lecture in the chapter section "Veränderungen" also reveals the duality of Eros and death when the subject turns to the mushroom impudicus, "dessen Gestalt an die Liebe, dessen Geruch jedoch an den Tod erinnerte" (551). Similarly in the chapter section "Noch jemand", Castorp dissects a flower (a symbol of romance) to discover that under the microscope the corolla swells erotically "zum abenteuerlich fleischigen Gebilde" (557); Castorp's interest in botany stems from his childhood awe at the floral abundance ("Blumenpracht") surrounding his Grandfather's coffin (46).

${ }^{828}$ Børge Kristiansen has noted that Mann changes the date of the sanatorium celebrations from 29 February to 30 April in order to underscore this connection to Faust (B. Kristiansen. Thomas Manns Zauberberg und Schopenhauers Metaphysik, op. cit., p. 191).

${ }^{829}$ The text of Der Zauberberg insinuates that the night ends for several patients with an erotic episode (see $512,516)$.

${ }^{830}$ Nietzsche KSA 6, pp. 310, 366. See 2.5, p. 52. The interrelation of Eros, birth and death within Dionysus is also reflected in Settembrini's description of ancient burial customs: "Die Alten schmückten ihre Sarkophage mit Sinnbildern des Lebens und der Zeugung, sogar mit obszönen Symbolen, - das Heilige war der antiken Religiosität ja sehr häufig eins mit dem Obszönen." (304; see also 397) Sven Jordan has traced this passage to Schopenhauer's report of the Greek and Roman tradition of decorating coffins with lusty scenes in the first volume of Die Welt als Wille und Vorstellung (S. Jordan, op. cit., p. 50; Schopenhauer I, p. 381). However, Settembrini's words also relate metatextually to the following fragment by Nietzsche: "Der Akt der Zeugung ist das Geheimniß an sich in allen nicht-asketischen Religionen: eine Art Symbol der Vollendung und der geheimnißvollen Absicht, der Zukunft (Wiedergeburt, Unsterblichkeit [sic]" (Nietzsche KSA 12, p. 331).
} 
Chauchat's symbolic representation of Eros and death is augmented by her diagnosis with lymphatic tuberculosis. Her resulting embodiment of disease corresponds selectively to Novalis's belief that disease transposes the characteristics of death onto life ("Kranckheiten sind lebendig scheinende Todte"). ${ }^{831}$ Chauchat's additional representation of life and Eros is similarly explained by Novalis's writing, specifically by his view of life as both a disease and an act of passion: "Leben ist eine Kranckheit des Geistes - ein leidenschaftliches Thun." 832 These texts by Novalis are inextricably linked to his theory of stimuli. Accordingly, Chauchat's complex symbolism reiterates the ambiguity of stimuli discussed in $3.1,3.4$ and 5.2, ${ }^{833}$ an ambiguity also reflected by the lymphatic tuberculosis within Chauchat's body. Lymphatic fluid is initially associated with life, following the description of Castorp's vision in the chapter section "Forschungen" as "von Lymph durchsickert[]" (420). This view of lymph is reminiscent of fragments from "Das Allgemeine Brouillon", in which Novalis reinterprets the stimuli of life as a liquid. ${ }^{834}$ Novalis's equation of stimuli and liquid anticipates Freud's following discussion of the sexual drives in Vorlesungen zur Einführung in die Psychoanalyse: "[D]ie sexuellen Triebregungen [sind] außerordentlich plastisch [...]. Sie verhalten sich zueinander wie ein Netz von kommunizierenden, mit Flüssigkeit gefüllten Kanälen". ${ }^{835}$ The erotic interpretation of liquid in Freud's text is clearly reflected in the context of lymph by Director Behrens in the following passage from "Humaniora": "Die Lymphe, das ist das Allerfeinste, Intimste und Zarteste [...] [,] der Saft des Saftes, die Essenz" (401). Furthermore, Behrens' view of lymph as the quintessential bodily fluid selectively and referentially parallels Schopenhauer's claim that semen is "die Sekretion der Sekretionen, die Quintessenz aller Säfte". ${ }^{836}$ These penile connotations continue when the association of swelling with desire initiated by Behrens' contemplation of "wieso dem Hahn eigentlich

\footnotetext{
${ }^{831}$ Novalis 3, p. 264. Novalis's idea is discussed by both Käte Hamburger (K. Hamburger op. cit., p. 68) and Georg Brandes (G. Brandes op. cit., p. 233).

832 Novalis 3, p. 659.

${ }^{833}$ See 3.1 , p. $69 ; 3.4$, p. $91 ; 5.2$, pp. 154-55.

${ }^{834}$ Novalis 3, p. 323. This fluid is, in accordance with Novalis's understanding of asthenic and indirectly asthenic constitutions, either dilute or condense depending on the capacity of the individual (ibid.).

${ }^{835}$ Freud XI, pp. 357-58.

${ }^{836}$ Schopenhauer II, p. 657.
} 
der Kamm schwillt - oder was für renommistische Beispiele anführen ließen” (399) is subsequently traced to the function of lymph to make flesh turgid (402). In Chauchat's case, this erotic lymphatic swelling is also pathological, following the inflammatory effect of lymphatic tuberculosis on the lymph nodes (402). ${ }^{837}$

The combination of Eros and disease within Chauchat proves irresistible. During the "Walpurgisnacht" revelries, Castorp farewells the affirmation of life espoused by Settembrini (entreating: “[V]erzeih mir also und denke meiner nicht im bösen!” [499]), and capitulates to Chauchat's darkly seductive powers. ${ }^{838}$ In search of a pencil with which to draw a pig with his eyes closed, Castorp approaches Chauchat for the first time. The blood drains from his face as he stands before her (504), i.e. his sexual excitement generates a resemblance to death; he also holds his head on one side (588), a posture associated throughout the novel with death-affirmation. ${ }^{839}$ Lending Castorp a "feminine" version of the pencil he once borrowed from Hippe ("[d]er Bleistift von damals, der erste, war viel handlich-rechtschaffener gewesen" [505]), Chauchat instigates a conversation in French (the language of love), ${ }^{840}$ during which Castorp declares his passion. Chauchat subsequently dismisses his infatuation with her as "folie!" (518) (“Wahnsinn!" [transl. 1095]), ${ }^{841}$ an association of Eros with disease that recalls both Schopenhauer's belief that love is "ein Wahn ohnegleichen", ${ }^{842}$ as well as Nietzsche's following claim in Also sprach Zarathustra: "Es ist immer etwas Wahnsinn in der Liebe." ${ }^{843}$ In addition, Castorp's

\footnotetext{
837 This follows Novalis's conclusion on the similarities between excitability and fluids: "Gefäß und Saftpathologie - Incitamentism und Irritabilitism sind schlechthin Eins" (Novalis 2, p. 573).

${ }^{838}$ See also Der Zauberberg, p. 514: "Je me soucie très peu de ce monsieur [Settembrini], quand mes yeux te [Chauchat] voient." ("Ich kümmere mich sehr wenig um diesen Herrn [Settembrini], wenn meine Augen dich [Chauchat] sehen." [transl. 1092])

${ }^{839}$ See 2.4, p. 45. Castorp also rests his chin on his collar in the presence of Chauchat (506), a posture initially assumed by Castorp's death-affirming grandfather (44), and which Castorp mimics prior to his vision of Hippe (representative of homosexuality and death) (181).

${ }^{840}$ French is also the original language of the risqué little book Die Kunst, zu verführen (413).

${ }^{841}$ Chauchat's connection between love and insanity is ironically prompted by Castorp's declaration: "La fièvre de mon corps et le battement de mon cœur harassé et le frissonnement de mes membres, c'est [...] rien d'autre que mon amour pour toi” (517) ("Das Fieber meines Körpers und das Schlagen meines erschöpften Herzens und das Zittern meiner Glieder, das ist [...] nichts anderes als meine Liebe zu dir" (transl. 1095).

${ }^{842}$ Schopenhauer II, p. 704; see also ibid., pp. 680, 688, 690, 692, 710.

${ }^{843}$ Nietzsche KSA 4, p. 49.
} 
eagerness to "avoir l'occasion d'étudier ta peau comme lui [Behrens]" (509) ("deine Haut so zu studieren wie er [Behrens]" [transl. 1087]) clearly reiterates the sexual symbolism of the epidermis discussed in 5.1. ${ }^{844}$ Indeed, the encounter between Castorp and Chauchat concludes with her suggestive invitation: "N'oubliez pas de me rendre mon crayon." (520) ("Vergessen Sie nicht, mir mein Crayon zurückzugeben" [transl. 1098]).

In accordance with Chauchat's representation of pathology, this implied erotic encounter is tantamount to Castorp's infection by disease. In chapter three of this thesis, I argued that the embrace between Castorp and his vision of Chauchat in the chapter section "Forschungen" replicates the contact described in his textbook between organism and pathogen. ${ }^{845}$ This moment of infection takes the form of a kiss reminiscent of the symbolism of Eros and death in Novalis's seventh "Geistliches Lied": "[W]er jemals / Von heißen, geliebten Lippen / Athem des Lebens sog / [...] Wird essen von seinem Leibe / Und trinken von seinem Blute / Ewiglich". 846 This excerpt on the mystical meaning of the Eucharist implies that Holy Communion enables transcendence, i.e. that it destroys the individual in the world. The eroticism inherent to Novalis's interpretation of the sacrament suggests in turn that divine Eros is this destructive power, an idea reflected in Peeperkorn's declaration that a love potion is a poison (875), as well as in Castorp's dream of the lusty Herr Miklosich carrying Frau Stöhr away in his jaws (141) ${ }^{847}$ - presumably in order to consume her. Miklosich's dual erotic and destructive intent is linked referentially to the chapter "Metaphysik der Geschlechtsliebe" from Die Welt als Wille und Vorstellung, in which Schopenhauer compares the male suitor to an ichneumon wasp laying its eggs in living insect larvae. ${ }^{848}$ This text modifies the conception of male libido and female receptivity discussed in $5.2^{849}$ to include the ultimate destruction of the female.

However, Castorp and Chauchat's relationship reverses these gender roles, and the female becomes the erotic, pathological stimulus that destroys the male. Thus, the text of

\footnotetext{
${ }^{844}$ See 5.1, p. 153.

${ }^{845}$ See 3.4, p. 92.

${ }^{846}$ Novalis 1, p. 167; also quoted in G. Brandes, op. cit., pp. 238-39.

${ }^{847}$ This dream is also discussed in subchapter 4.5 (see p. 133).

${ }^{848}$ Schopenhauer II, p. 690.

${ }^{849}$ See 5.2, pp. 158-60.
} 
Der Zauberberg corresponds most selectively to the following passage from Nietzsche's Der Fall Wagner: "In vielen Fällen der weiblichen Liebe [...] ist Liebe nur ein feinerer Parasitismus, ein Sich-Einnisten in eine fremde Seele, mitunter selbst in ein fremdes Fleisch - ach! wie sehr immer auf 'des Wirthes' Unkosten!" 850 Just as Nietzsche's female parasite burrows into the flesh of the male, Chauchat's embrace of Castorp in the chapter section "Forschungen" indicates her intent to devour him. ${ }^{851}$ However, Castorp's passive “female" receptivity of Chauchat's kiss reflects Dr Schreber's role as God's homosexual "Weib[]". ${ }^{852}$ According to this referential, metatextual connection, the agency of masculine desire is reinstated, and Chauchat consequently appears to represent (divine) masculine erotic stimulus. The destructive power of this stimulus is suggested in the chapter section "Walpurgisnacht" by “[der] listige[n] Erregung" (505) with which Chauchat greets Castorp's approach, a reaction that suggests a spider's taut anticipation of a wandering fly.

\subsection{Pleasure and pain}

The ambiguity inherent in Madame Chauchat's complex representation of life, death, disease and Eros (see above) is reflected ironically in the portrayal of cigars. ${ }^{853}$ Reiterating the similarities identified between the effects of stimulants and Eros in 5.2, ${ }^{854}$ Castorp's "bräunliche Schöne" (384) in the chapter section "Humaniora" is a living, breathing female: “['Maria'] hat Leben. Sie atmet regelrecht" (384). Behrens' own temperamental, juicy cigar (384) extends this female metaphor to include Eros, and he warns Castorp: "Einige Zurückhaltung im Verkehr wird empfohlen, man kann nicht eine an der anderen anzünden, das geht über Manneskraft” (384). Yet the implied femininity of the cigar is undermined by its phallic shape, which is rendered unmistakeably penile when the veins of the tobacco leaf appear to throb (384). Such masculinity is associated with death in Der Zauberberg, ${ }^{855}$

\footnotetext{
${ }^{850}$ Nietzsche KSA 6, p. 18. Novalis describes woman's attractiveness in similarly negative terms ("das Miasma weiblicher Reitze" [Novalis 2, p. 559]).

${ }^{851}$ Chauchat's metaphorical association with the parasite in Castorp's textbook is discussed in 3.4 (see p. 92 ).

852 Freud VIII, p. 268.

${ }^{853}$ The ambiguous nature of stimulants is also discussed in 3.4 (see p. 93).

${ }^{854}$ See 5.2, pp. 155-56.

${ }^{855}$ See 5.1, pp. 148-49.
} 
and it is therefore no surprise when Castorp compares smoking to the feeling of lying on a beach (77). ${ }^{856}$ The ocean is later equated with the dissolution of time and space (824) synonymous with death. ${ }^{857}$

The cigar's hermaphroditic representation of the stimulus of life, Eros and death ${ }^{858}$ is subsequently augmented to include disease when Director Behrens recounts his lifethreatening incident with three "Henry Clay's" (385). ${ }^{859}$ This experience prompted feelings of fear and pleasure ("Angst und Festivität" [385]), a mix established as erotic when Behrens compares himself to a Bengali on his wedding night (385). Behrens' encounter with these Henry Clay's thus relates selectively to Die romantische Schule in Deutschland, in which Georg Brandes claims that Novalis's concept of lust encapsulates "ein[en] unentschiedene[n] Kampf zwischen Lust und Schmerz". ${ }^{860}$ Nietzsche similarly declares through the mouthpiece of Zarathustra: "[A]uch noch eure beste Liebe ist ein verzücktes Gleichniss und eine schmerzhafte Gluth". ${ }^{861}$ These definitions of lust and love as painful relate further to the belief held by both Schopenhauer and Nietzsche that pain and pleasure are intrinsic to life. ${ }^{862}$ However, the relation of these last texts to Der Zauberberg is complicated by the fact that Director Behrens' erotic feelings of pain and pleasure are stimulated by disease. This apparent dialogical clash between primary text and intertexts actually reflects the ambiguous nature of stimuli: further passages in Der Zauberberg indicate that lusty feelings of pain and pleasure are elicited by stimuli affiliated to both life

\footnotetext{
${ }^{856}$ Castorp's feeling of safety while smoking ("hat man eine gut Zigarre, dann ist man eigentlich geborgen, es kann einem buchstäblich nichts geschehn" [77]) is thus reflected by the beach wanderer's feeling of being "geborgen von Ewigkeit" (825). Freud discusses the association of the ocean with eternity in "Das Unbehagen in der Kultur" (1930) (Freud XIV, pp. 421-22), and in "Von deutscher Republik" Thomas Mann reiterates this association clearly: "Denn Liebe zum Meer, das ist nichts anderes als Liebe zum Tode" (Mann 15.1, p. 557).

${ }^{857}$ See 4.3, pp. 114-17. These passages bring a Romantic interpretation of Schopenhauer's concept of Nunc stans into contact with Novalis's following fragment: "Das Meer ist das Element von Freiheit und Gleichheit." (Novalis 2, p. 487)

${ }^{858}$ The phallic pencil is similarly used in the chapter section "Walpurgisnacht" in the context of both Castorp's sexual encounter and his capitulation to Chauchat's death-affirming stance.

${ }^{859}$ See also 4.4, p. 123.

${ }^{860}$ G. Brandes, op. cit., p. 233. Brandes' conclusion appears to follow the joy, longing and violence combined in the erotic experience of heaven from the seventh of Novalis's "Geistliche Lieder" (Novalis 1, pp. 167-68).

${ }^{861}$ Nietzsche KSA 4, p. 92.

${ }^{862}$ Schopenhauer I, p. 143; Nietzsche KSA 2, pp. 39, 339.
} 
and disease. In the chapter section "Forschungen", for example, Mind reacts with "halb Vergnügen, halb Abwehr" (433) to its infiltration by pathological stimuli that simultaneously enable the creation of life from the inorganic, and Castorp is consumed by "Lust und Grauen" (434) as he is embraced by his vision of life that takes the form of the diseased Chauchat. ${ }^{863}$

The ambiguous reactions to the stimulus of life and disease in the passages quoted above are merged in Der Zauberberg in the portrayal of pain as a source of pleasure. Thus, in the chapter section "Das Thermometer", Frau Stöhr embarks on a monologue to her fellow patients on the delights of (tubercular) coughing, sneezing, and of scratching her chilblains:

[Frau Stöhr] erging sich über die Vergnüglichkeit des Hustens, - Ja, es habe unbedingt eine unterhaltliche und genußreiche Bewandtnis damit, wenn in den Gründen der Brust der Kitzel sich mehre und wachse und man mit Krampf und Pressung so recht tief hinunterlange, um dem Reiz zu genügen: ein ähnlicher Spaß sei das wie das Niesen, wenn die Luft dazu gewaltig anschwelle und unwiderstehlich werde und man mit berauschter Miene ein paarmal stürmisch ausund einatme, sich wonnig ergäbe und über den gesegneten Ausbruch die ganze Welt vergäße. Und manchmal komme es zwei-, dreimal hintereinander. Das seien kostenfreie Genüsse des Lebens, wie beispielsweise auch noch, sich im Frühling die Frostbeulen zu kratzen, wenn sie so süßlich juckten, - sich so recht innig und grausam zu kratzen bis aufs Blut in Wut und Vergnügen, und wenn man zufällig in den Spiegel sähe dabei, dann sähe man eine Teufelsfratze [...]. (263-64)

Frau Stöhr's delight at scratching herself until she bleeds anticipates a passage from the chapter section “Totentanz", in which Frau Zimmermann, despite suffering from an acute lack of oxygen, ${ }^{864}$ "lacht[] beständig perlend, ganz hoch und silberhell, indem sie nach Atem r[ingt], erregt und gekitzelt, wie es schien, von ihrer Beklemmung” (463). The evident enjoyment of these two ladies is perplexing: how can pain and discomfort elicit feelings of pleasure? The answer to this question is revealed by the motif of tickling present in both passages. In this thesis, I have demonstrated that in Der Zauberberg, ticklishness

\footnotetext{
${ }^{863}$ See 3.4, p. 92. Castorp also feels fear and triumph at his diagnosis with tuberculosis (280) (see 2.3, p. 36), and a mixture of suffering and joy as he becomes ill with a fever in the chapter section "Satana macht ehrrührige Vorschläge" (137).

${ }^{864}$ See 2.4, p. 46.
} 
represents the organism's sensitivity to the stimulus of life, disease and Eros. ${ }^{865}$ Frau Stöhr and Frau Zimmermann's enjoyment of pain amalgamates the organism's response to disease and Eros by suggesting that pathological stimuli provoke erotic, pleasurable feelings. This is clear from Frau Stöhr's orgasmic sneezing, as well as from Frau Zimmermann's “arousal” by suffocation. Frau Stöhr's and Frau Zimmermann's experiences of pain consequently relate highly selectively to the following fragment by Novalis: "[I]n dem Augenblicke, als ein Mensch die Kranckheit oder den Schmerz zu lieben anfienge, läge die reitzendste Wollust in seinen Armen - die höchste positive Lust durchdränge ihn. [...] - Je fürchterlicher d[er] Schmerz desto höher die darinn verborgene Lust". ${ }^{866}$ Novalis's conclusion that erotic sensations are consequent to pain follows his belief that disease enhances the body. ${ }^{867}$ This idea is reflected metatextually in numerous passages within Der Zauberberg, for example in Castorp's study of pathology in the chapter section "Forschungen", which concludes: "So weit die Pathologie, die Lehre von der Krankheit, der Schmerzbetonung des Körpers, die aber, als Betonung des Körperlichen, zugleich eine Lustbetonung war" (432; see also 433, 409, 647). In the chapter section “"Mein Gott, ich sehe!", Castorp similarly ruminates that Chauchat's body has been erotically enhanced by disease (314), an idea which suggests that Madame Chauchat's representation of Eros is consequent to her lymphatic tuberculosis. The causal relationship between disease and Eros also leads the reader to modify the concept of the body as God's medium ${ }^{868}$ in the idea that the body is the lusty medium of disease.

The body's erotic response to pathological stimulus is also illustrated by Ferdinand Wehsal's obsession with Madame Chauchat. Wehsal's name translates from Old High German as "misery", or "cruel fate"; 869 and indeed, his desire is met by Chauchat's cold disdain (931-36). Yet contrary to Schopenhauer's belief that suffering negates the Will to

\footnotetext{
${ }^{865}$ See 3.1, p. 68; 3.4, p. 91; 5.2, pp. 155-56.

${ }^{866}$ Novalis 3, p. 389; see also Novalis 2, p. 614.

${ }^{867}$ G. Brandes, op. cit., p. 233.

${ }^{868}$ See 5.2, pp. 160-61.
}

$869 \quad$ J. \& W. Grimm. Deutsches Wörterbuch, op. cit. http://woerterbuchnetz.de/DWB/?sigle=DWB\&mode=Vernetzung\&lemid=GW12109; online resource accessed 12 June 2014. 
live,${ }^{870}$ the pain of Wehsal's unrequited love does not extinguish his passion. As he explains to Castorp in the chapter section "Mynheer Peeperkorn (Schluß)":

[W]en es hat, der kann es nicht wegwünschen, man müßte sein Leben wegwünschen, womit es sich amalgamiert hat, und das kann man eben nicht, - was hätte man davon, zu sterben? Nachher, - mit Vergnügen. In ihren Armen, - herzlich gern. Aber vorher, das ist Unsinn, denn das Leben, das ist das Verlangen, und das Verlangen das Leben [...]. (933)

This interrelation of lust and life was linked previously to the stimulating function of both ${ }^{871}$ however, the ambiguous nature of stimuli affiliated with life, Eros and disease casts doubt on Wehsal's claim that to abandon his pain would be to abandon life. Perhaps Wehsal's attachment to his torment is really due to his enjoyment of painful sensations? Nietzsche notes such pathological craving in the aphorism "Begierde nach tiefem Schmerz" from Menschliches, Allzumenschliches: "[M]an will, wie es scheint, die heftigere Unlust immer noch lieber als die matte Lust". ${ }^{872}$ Freud similarly remarks: "Endlich ist alles Leid nur Empfindung" ${ }^{873}$ In fact, following the sexual nature of the repressed drives responsible for neurosis, Freud believes that "alle neurotische Unlust [...] ist Lust, die nicht als solche empfunden werden kann". ${ }^{874}$ This text indicates that pain has an erotic core, thereby signalling that Wehsal's suffering may be transfigured lust; this idea is upheld in the primary text when Chauchat's disdain is described as a "Lustfolter" (935), one that presumably makes Wehsal writhe with erotic sensations.

Wehsal's "Lustfolter" (935) is anticipated in the chapter section "Operationes spirituales", in which the torture chambers of the inquisition are portrayed as places of sensual pleasure: "[D]ort hatte man dem Leibe um der Seele willen recht unzärtlich zugesetzt, auf mancherlei sinnreiche Weise" (691). ${ }^{875}$ This sensual torment continues in

\footnotetext{
${ }^{870}$ Schopenhauer II, p. 808.

${ }^{871}$ See 3.1, pp. 67-69; 5.2, pp. 154-55.

${ }^{872}$ Nietzsche KSA 2, p. 344.

${ }^{873}$ Freud XIV, p. 436.

${ }^{874}$ Freud XIII, p. 7; see also Freud V, p. 58.

${ }^{875}$ Wehsal is highly enthusiastic about torture, so much so that his attention lags when the subject is changed ("Wehsal zeigte sich wenig beteiligt, seitdem nicht mehr von Prügeln und Folter die Rede war" [705]). This approval of suffering is anticipated in Der Zauberberg by Naphta's description of the Freemasons and of
} 
Naphta's report of Saint Elisabeth, who was tortured "aufs Blut [...], wodurch 'ihre Seel', wie es in der Legende hieß, 'entzuckt' [sic] worden war, 'bis in den dritten Chor'” (686). The ascetic persecution of the flesh in these passages relates metatextually to Novalis's approval of the inquisition in "Die Christenheit oder Europa". ${ }^{876}$ Yet the erotic component of torture more closely corresponds to the conviction of both Novalis and Nietzsche that cruelty is essentially erotic. Novalis declares: "Sonderbar, daß der eigentliche Grund der Grausamkeit Wollust ist"; 877 Nietzsche similarly claims: "Grausamkeit ist eine versetzte und geistiger gewordene Sinnlichkeit." 878 Schopenhauer reverses this relationship between cruelty and lust by describing Cupid as "feindselig" and "grausam", 879 and Freud establishes their mutual dependence: "Grausamkeit und Sexualtrieb [gehören] innigst zusammen". 880

This interrelation of lust and cruelty is realised within Wehsal's obsession as a certain antipathy towards the object of his desire. As he declares to Castorp in the chapter section "Mynheer Peeperkorn (Schluß)": "Ich würde ihr [Chauchat] alle Wollust der Welt antun, Castorp [...], wenn ihre verfluchte Seele nicht wäre, die nichts von mir wissen will” (935). This peculiar ambivalence selectively parallels Schopenhauer's conviction that lust does not preclude intellectual dislike ("[e]ndlich verträgt sich die Geschlechtsliebe sogar mit dem äußersten Haß gegen ihren Gegenstand”). ${ }^{881}$ Similarly, Freud believes that all love contains an element of hate, ${ }^{882}$ and Nietzsche shares this view, tracing it to the natural antipathy of the sexes: “[D]ie Liebe, [ist] [...] in ihren Mitteln der Krieg, in ihrem Grunde

ascetic mediaeval monks $(570,675$ (see also 2.4, p. 48). The link between disease and pleasure also relates to Schopenhauer's affirmation of suffering (see 2.4, p. 47).

${ }^{876}$ Novalis 3, pp. 508-09; see also G. Brandes, op. cit., p. 245.

${ }^{877}$ Novalis 3, p. 655; similarly: "[G]ezähmte Rohheit [ist eine der] Elemente der gewöhnlichen Wollust." (ibid., p. 684)

${ }^{878}$ Nietzsche KSA 10, p. 64. Nietzsche also considers natural love to be "cynisch, unschuldig, grausam" (Nietzsche KSA 6, p. 15).

${ }^{879}$ Schopenhauer II, p. 713.

${ }^{880}$ Freud V, p. 58; see also ibid., p. 93; Freud XIII, p. 58.

${ }^{881}$ Schopenhauer II, pp. 711-12.

${ }^{882}$ Freud XV, p. 110; see also ibid., p. 57; Freud X, pp. 231-32; Freud XIII, p. 57. 
der Todhass der Geschlechter". 883

Wehsal's obsession despite his ambivalence is reminiscent of Schopenhauer's following discussion of neurosis: “[Es gibt] Fälle[], wo Einer den Anlaß, über welchen er verrückt geworden, beständig gegenwärtig behält und nicht davon los kommen kann: so z.B. bei manchem verliebten Wahnsinn, Erotomanie". ${ }^{84}$ According to Freud, such neuroses are caused by the repression of sexual drives; ${ }^{885}$ this attempt by the intellect to dominate Eros is illustrated in Der Zauberberg in tension between Wehsal's feelings of lust and shame:

Jede Nacht träume ich von ihr, ach, was träume ich nicht alles von ihr, es brennt mir im Schlunde und in der Magengegend, wenn ich dran denke! Und immer endet es damit, daß sie mir Ohrfeigen gibt, mich ins Gesicht schlägt und manchmal auch anspeit, - mit vor Ekel verzerrtem Seelenangesicht speit sie mich an, und dann wache ich auf, mit Schweiß und Schmach und Lust bedeckt... (935)

The "Schmach" in this passage relates selectively to Freud's belief that shame and disgust are tools of the superego to control erotic desire. ${ }^{886}$ This idea is pre-empted by Nietzsche's "hässlichster Mensch", who kills God for witnessing his "verhehlte Schmach und Hässlichkeit", ${ }^{887}$ his "verborgene[] Scham". ${ }^{888}$ Nietzsche's text perpetuates the link

\footnotetext{
${ }^{883}$ Nietzsche KSA 6, p. 15. This follows Nietzsche's conviction that love is an expression of the will to power (Nietzsche KSA 13, p. 312).

${ }^{884}$ Schopenhauer II, p. 517; see also ibid., pp. 705, 710. This is consequent to Schopenhauer's belief that the drives dominate the intellect (see 3.2, p. 77). Thus, Schopenhauer claims that even the most rational lover "steht unter dem Einfluß eines Triebes, der, dem Instinkt der Insekten verwandt, ihn zwingt, allen Gründen der Vernunft zum Trotz seinen Zweck unbedingt zu verfolgen und alles andere hintanzusetzen: er kann nicht davon lassen" (Schopenhauer II, p. 712).

${ }^{885}$ Freud VII, p. 144-45.

${ }^{886}$ Freud V, pp. 60, 61 (footnote 1), 78. The hysteric's unusually strong sexual drive is countered by an equally strong sense of shame (ibid., p. 64).

${ }^{887}$ Nietzsche KSA 4, p. 331.

${ }^{888}$ Ibid., p. 332. The link between Wehsal and Nietzsche's "hässlichster Mensch" is particularly clear from the former's desperate wail: "Bin ich denn kein Mann? Ist ein widerwärtiger Mann kein Mann?" (934-35). An alternative interpretation of this passage is made by E. Joseph, who sees Wehsal as representative of Nietzsche's man of resentment (E. Joseph, op. cit., pp. 101-03). This "Mensch des Ressentiment" in Zur Genealogie der Moral, who "versteht sich auf [...] das vorläufige Sich-verkleinern, Sich-demüthigen" (Nietzsche KSA 5, p. 272), is clearly related to the "hässlichster Mensch".
} 
between Eros and God established in $5.2^{889}$ by presenting God as a peeping Tom. In contrast, the denial of Eros is inferred as a characteristic of the devil. Thus, Wehsal's unfulfilled desire is a hell ("Schandhölle" [935]), to which he has been condemned by Chauchat's disdain: “[D]essentwillen ist mein Verlangen zur Schande verdammt, und mein Leib muß sich winden ewiglich!” (934).

Wehsal's tortured longing can also be interpreted as essentially Romantic following Nietzsche's characterisation of Wagner's Tristan und Isolde as "[eine] Wollust der Hölle". ${ }^{890}$ Yet the self-indulgence of Wagner's music in the eyes of Nietzsche hints that Wehsal's torture may be self-inflicted. This idea recalls Freud's discussion of masochistic impulses from Vorlesungen zur Einführung in die Psychoanalyse and "Das ökonomische Problem des Masochismus" (1924). ${ }^{891}$ Freud's definition of the masochist as someone addicted to humiliation ${ }^{892}$ is arguably a prototype for Wehsal, whose following lament conjures up the image of a dog plagued by fleas: "[Es ist] zuweilen derart, daß ich mich in den Arm beiße und in die Luft greife und mir nicht zu helfen weiß” (933). ${ }^{893}$ The potentially erotic nature of this masochism is particularly clear in Castorp's memory of being beaten by a fellow schoolboy in the chapter section "Operationes spirituales":

[Er wurde] von einem stärkeren Mitschüler einmal geprügelt [...], einem großen Flegel, mit dem biegsamen Stock auf die Oberschenkel und die nur mit Strümpfen bekleideten Waden, und das hatte ganz schmählich weh getan, infam, unvergeßlich, geradezu mystisch, unter schändlich innigem Stoßschluchzen waren ihm die Tränen nur so hervorgestürzt vor Wut und ehrlosem Wehsal [...]. (687) ${ }^{894}$

\footnotetext{
${ }^{889}$ See 5.2, pp. 160-63.

${ }^{890}$ Nietzsche KSA 6, p. 290.

${ }^{891}$ Freud XI, p. 316; Freud XIII, pp. 372-83; see also Freud XIV, p. 147. Anton Karlowitsch Ferge's love of repeating his pleural shock experience (see 2.1 , pp. 27-28; 3.3, pp. 82-85) is similarly masochistic.

${ }^{892}$ Freud XI, p. 316; see also Freud XIII, p. 374.

893 Despite this, Wehsal himself claims: "[I]ch bin doch kein Vieh, in meiner Art bin ich doch auch ein Mensch!" (934). Thus, once again, Wehsal shares characteristics with Nietzsche's "hässlichster Mensch", whose self-loathing does not negate his humanity (Nietzsche KSA 4, pp. 327-32).

894 The reference in this passage to "wehsal" pokes fun at Wehsal himself (Castorp adds: "Herr Wehsal mochte freundlichst das Wort entschuldigen" [687]).
} 
Castorp's encounter is confirmed as erotic by the reference to his pain as "mystisch" ${ }^{895} \mathrm{His}$ experience of pain thus corresponds (albeit replacing the thighs and calves with the buttocks) to Freud's following claim from Drei Abhandlungen zur Sexualtheorie: "Als eine erogene Wurzel des passiven Triebes zur Grausamkeit (des Masochismus) ist die schmerzhafte Reizung der Gesäßhaut [bei der körperlichen Züchtigung von Kindern]". 896 This passage clearly reiterates the link between skin and Eros established in 5.1; ${ }^{897}$ furthermore, by linking this erotic experience of corporal punishment to psychological disorder, Freud's text inverts the process in which pathogens stimulate erotic sensation to make Eros the origin of pathology.

Within the context of masochism in Der Zauberberg, this pathological potential is reconfigured as the individual's desire for damaging erotic sensations. This necessitates a re-evaluation of Castorp's relationship with the pathogen Chauchat, since rather than a passive object to be consumed by the sexual male (Chauchat), ${ }^{898}$ it seems that Castorp actively desires to be devoured. This self-destructive reaction to disease selectively parallels the following fragment by Novalis: "Kranckheit - der Selbstzerstörungsinstinkt". ${ }^{899}$ Castorp's erotic will to self-destruction also recalls Novalis's first "Hymne an die Nacht", which concludes: "[Z]ehre mit Geisterglut meinen Leib, daß ich luftig mit dir inniger mich mische und dann ewig die Brautnacht währt". ${ }^{900}$ This erotic craving for death anticipates Freud's belief that masochism is related to the death drive. ${ }^{901}$ Castorp's masochistic desire to succumb to Chauchat thus appears to mimic that of the organism in the chapter section "Forschungen", which embraces its own demise following the stimulation of its cells by bacterial toxins (432). ${ }^{902}$ Similarly, the joy elicited by Director Behrens' experience with his three poisonous "Henry Clay's" ultimately outweighs his

\footnotetext{
${ }^{895}$ See 5.2, pp. 160, 162.

${ }^{896}$ Freud V, p. 94.

${ }^{897}$ See 5.1, p. 153.

${ }^{898}$ See 5.3, pp. 167-68.

${ }^{899}$ Novalis 2, p. 644.

${ }^{900}$ Novalis 1, p. 133; see also G. Brandes, op. cit., p. 242.

${ }^{901}$ Freud XIII, p. 377.

${ }^{902}$ See 2.5, p. 60 .
} 
fear, and he reflects: "Na, ich wäre [...] beinahe geschmolzen, mit wogendem Busen wollte ich abtanzen" (385). The theme of pleasure in self-destruction is also explored in the chapter section "Ewigkeitssuppe und plötzliche Klarheit", in which Dr Krokowski's lecture on "[die] Selbstvergiftung des Organismus" (286) concerns the body's production of poisonous substances with effects similar to those of morphine or cocaine.

The definitive role of Eros in the interrelation of pathology and pleasure common to Behrens' experience, to the description of the diseased organism in Castorp's textbook, and to Krokowski's lecture on poisons is confirmed by their selective metatextual connection to Freud's Vorlesungen zur Einführung in die Psychoanalyse. Here, Freud discusses Graves' disease and its cause by internally-produced poisons, and comes to the conclusion that neuroses might be similar:

[D]ie Neurosen [können wir] als Folgen von Störungen in einem Sexualstoffwechsel [an]sehen, sei es, daß von [...] Sexualtoxinen mehr produziert wird, als die Person bewältigen kann, sei es, daß innere und selbst psychische Verhältnisse die richtige Verwendung dieser Stoffe beeinträchtigen [...]. ${ }^{903}$

This text augments Freud's theory that neuroses are caused by the repression of drives ${ }^{904}$ with an equivalence of these drives and pathological toxins. Freud's idea is clearly related to the portrayal of erotic pathogens in the passages from Der Zauberberg discussed above, and it compounds the message in the primary text that the impetus to die is created by the pleasurable stimulus of Eros. This erotic desire for death also strongly reflects the essay "Jenseits des Lustprinzips", in which Freud compares the release of tension inherent to death to the pleasure of orgasm. ${ }^{905}$ The presence of the erotic death drive in Der Zauberberg underscores the idea established in chapter two of this thesis that death dominates life. ${ }^{906}$ In addition, the Eros within the death drive negates the previous association of the erotic

\footnotetext{
${ }^{903}$ Freud XI, p. 403.

${ }^{904}$ See 3.4, pp. 91-92.

${ }^{905}$ Freud XIII, pp. 67-78.

${ }^{906}$ See 2.5 , p. $61 ; 2.6$, pp. 62-64.
} 
with life, and instead indicates a preference within the novel for life-denying (homosexual) $^{907}$ relationships.

\subsection{Conclusion}

This chapter has demonstrated that the interpretation of life, death, disease and Eros in Der Zauberberg is enriched by the reader's knowledge of texts by Novalis, Schopenhauer, Nietzsche and Freud. These texts allow insight into the symbolism of life, nature and Eros within the female body, and also reveal that the androgynous Madame Chauchat is in fact an object of homosexual love aligned with aesthetics and death. The antithesis of female Eros and male aesthetics is encapsulated within the human body as beautiful form and hideous sexuality; however, this is deconstructed by the portrayal of the external body as disgusting sexual flesh, a negation of both the feminine and the masculine that reveals an ambivalent attitude towards life and death.

The erotic sensuality of the skin in Der Zauberberg leads to an association between Eros, love and the stimulus of life. This duality of physical sensitivity and stimulus is gendered, and the sensitive female consequently viewed as the passive object of male desire. However, the male body's communion with God (synonymous with male libido) is essentially homosexual; the implied rejection of the female body is confirmed when Naphta circumvents the body entirely by transferring lust to the spirit. This interrelation of Eros and God (death) reconfigures the Christian duality of love and death, an ambiguous affiliation that is reflected within the erotic disease of Madame Chauchat. Chauchat's parasitic seduction of Castorp thus illustrates that Eros, while associated with life, is essentially destructive.

The ambiguity of stimuli embraces life, Eros, death and disease, and is reflected in the organism's mixed erotic response to stimulus. These positive and negative reactions are amalgamated in the idea that pain produces erotic sensations. Ferdinand Wehsal's obsession with Madame Chauchat thus shares an erotic fundament with torture, and also combines feelings of love and hate. Wehsal's masochistic pleasure in pain is also experienced by Castorp, and the latter's capitulation to the seduction of Madame Chauchat

${ }^{907}$ See 5.1, pp. 148-49. 
illustrates the erotic power of pain to prompt a death drive within the organism. Transferred to the analysis of life and death, this eagerness to embrace the destructive power of Eros affirms both death and homosexuality. 


\section{Chapter 6. Culture, Eros, death and disease}

\subsection{Culture versus nature: Morality, Eros and disease}

The death drive discussed in the previous subchapter is linked to the degeneration of culture. This is clear from the following fragment by Nietzsche: "Eine Art Selbstzerstörung, der Instinkt der Erhaltung compromittirt... Der Schwache schadet sich selber... das ist der Typus der decadence..." 908 Considering the association of the death drive with Eros, ${ }^{909}$ knowledge of Nietzsche's text leads the reader to question whether Eros might also be linked to the disintegration of culture portrayed in Der Zauberberg. The present chapter seeks to answer this question by examining the themes of Eros, death, disease and culture in the novel, beginning with an investigation of Eros and its relation to morality.

The sensitivity to stimuli characteristic of organic matter ${ }^{910}$ was identified in the previous chapter as potentially erotic. ${ }^{911}$ This eroticism within life's most basic characteristic can be traced to the creation of life as it is portrayed in the chapter section "Forschungen". Here, the response of matter to life-giving pathological stimulus clearly prefigures the sensual reaction of the organism to its own demise: ${ }^{912}$ “[D]as Leben [...] [war nur ein] Schamwärmereflex der zur Fühlsamkeit geweckten Materie, die für den Erwecker aufnahmelustig gewesen war" (433). ${ }^{913}$ However, this erotic response is judged negatively in the novel in further descriptions of life as immoral ("unzüchtig" [418]) and unclean ("eine wollüstig-verstohlene Unsauberkeit" [418; see also 416]). ${ }^{914}$ In 3.5, I established that the creation of life is equated in Der Zauberberg with sin; ${ }^{915}$ it now appears

\footnotetext{
${ }^{908}$ Nietzsche KSA 13, p. 279.

909 See 5.4, pp. 176-78.

${ }^{910}$ See 3.1, pp. 67-69.

911 See 5.2, pp. 154-55.

912 See 2.5 , p. $60 ; 5.4$, pp. $176-78$.

913 This sexual disease of Mind reiterates the relationship between pathogen and organism: "[D]as Eindringen fremdartiger Zellen in einen Organismus, der sich für sie aufnahmelustig erwiesen hatte und ihrem Gedeihen auf irgendeine Weise - aber man mußte wohl sagen: auf eine irgendwie liederliche Weise - günstige Bedingungen bot" (431-32).

914 Nature is similarly unclean (411); this follows the equivalence of female life and nature and the portrayal of women as repulsive discussed in 5.1 (see pp. 144, 150-51).

915 See 3.5, p. 99.
} 
that this sin is due to life's erotic reception of disease. This relates to the idea, established in subchapters 3.4 and 3.5, that life was created by the tickle of Mind by disease. ${ }^{916}$

The concept of life as guilty of eroticism metatextually parallels Schopenhauer's following statement in Die Welt als Wille und Vorstellung:

[D] as menschliche Dasein [...] hat ganz und gar den [Charakter] einer kontrahierten Schuld. Die Einforderung derselben erscheint in Gestalt der durch jenes Dasein gesetzten dringenden Bedürfnisse, quälenden Wünsche und endlosen Not [...]. Und wann wurde diese Schuld kontrahiert? - bei der Zeugung. ${ }^{917}$

The message of Schopenhauer's text follows the story of Genesis, in which Adam and Eve are cast out of the Garden of Eden after Adam accepts an apple (symbolic of Eros) from Eve. Genesis also informs Naphta's declaration in the chapter section "Mynheer Peeperkorn (Des Weiteren)" that Eros is guilty: "[N]ie könne Wollust ohne Schuld sein" (892; see also 891, 894). In contrast, Settembrini defends Eros as innocent (“[Settembrini] brach eine Lanze für die Unschuld der Wollust” [892]). These antithetical viewpoints held by the Christian Naphta and the atheist Settembrini correspond referentially and selectively to Nietzsche's claim in Also sprach Zarathustra that Christianity has corrupted the essential innocence of lust. ${ }^{918}$

Settembrini's positive view of Eros is linked to his affirmation of life as "Erneuerung" (304), which relates to Nietzsche's conviction that the innocence of Eros is based on its connection to life ("[w]o ist Unschuld? Wo der Wille zur Zeugung ist"). ${ }^{919}$ Nietzsche's emphasis on procreation leads the reader to question his affirmation of lust per se; and indeed, in the following aphorism from Menschliches, Allzumenschliches, Nietzsche appears to argue in favour of erotic restraint: "Ein Mensch, der über seinen Jähzorn, seine Gall- und Rachsucht, seine Wollust nicht Meister werden will [...] ist so

${ }^{916}$ See 3.4, p. 98; 3.5, pp. 98-99.

${ }^{917}$ Schopenhauer II, p. 743; this passage is also noted by Sven Jordan (S. Jordan, op. cit., p. 57).

918 Nietzsche KSA 4, p. 157; Nietzsche KSA 3, p. 73; see also Nietzsche KSA 4, pp. 156, 157; Nietzsche KSA 9, p. 240.

${ }^{919}$ Nietzsche KSA 4, p. 158; see also Nietzsche KSA 6, p. 307. 
dumm wie der Ackermann, der neben einem Wildbach seine Aecker anlegt, ohne sich gegen ihn zu schützen." ${ }^{.920}$ A similar stance is adopted by Novalis, who warns: "Wenn man sich gehn läßt, so entsteht allmälich ein Ungeheuer in seiner Art. So in Brutalitaet, in

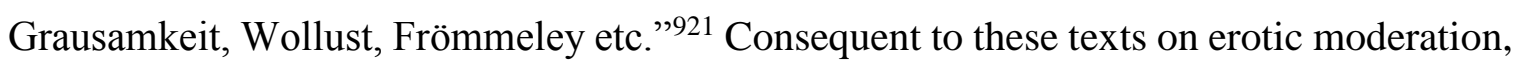
the connection established between Settembrini's conception of Eros and the message of Nietzsche's text quoted earlier calls Settembrini's stance in favour of the erotic and his subsequent opposition to Naphta into question.

Indeed, Settembrini's actual condemnation of Eros is manifest in his criticism of both Dr Krokowski and Director Behrens (99). The clinical rooms of these two doctors are spaces of intimacy, in which the sanatorium patients expose themselves physically and psychologically. In subchapter 5.2, I established the erotic nature of Dr Krokowski's psychoanalysis together with his peculiar effect on the female sanatorium patients. ${ }^{922}$ Settembrini's disapproval of these particulars is revealed in the chapter section "Satana" when he exclaims: "Dort geht er [Dr Krokowski] und weiß alle Geheimnisse unserer Damen [...]. Dieser Mann hat in seinem Kopf nur einen Gedanken, und der ist schmutzig." (99) Director Behrens is similarly lecherous: according to Frau Stöhr, Frau Redisch is required to march "wöchentlich einmal zehn Minuten lang vollständig nackt vor Hofrat Behrens im Zimmer hin und her" (452). Moreover, Behrens' x-rays are linked to pornographic photography in the chapter section "“Mein Gott, ich sehe!"”. Here, Behrens invites Castorp to view his "Privatgalerie" of x-rays after declaring: "Seien Sie ruhig, es geht ganz ästhetisch zu" (327).

However, Settembrini's negative view of Eros is essentially antithetical to his affirmation of life, and this sparks the reader's interest. An explanation is provided in the chapter section "Notwendiger Einkauf", in which Settembrini notes the antipathy of the scholar Leopardi towards nature (153). Similarly, Settembrini declares when discussing Voltaire's rejection of the natural catastrophe in Messina: "[D]a haben Sie die Feindschaft des Geistes gegen die Natur, sein stolzes Mißtrauen gegen sie, sein hochherziges Bestehen

\footnotetext{
${ }^{920}$ Nietzsche KSA 2, p. 581.

${ }^{921}$ Novalis 2, p. 603.

922 See 5.2, p. 158.
} 
auf dem Rechte zur Kritik an ihr und ihrer bösen, vernunftwidrigen Macht” (380). These passages establish the presence of a rift in Enlightenment thought between Mind and Nature that significantly parallels the Christian duality of body and soul ("Fleisch und Geist" [610]). ${ }^{923}$ Castorp tacitly acknowledges this compatibility between Christian dogma and Enlightenment thought in the chapter section "Operationes spirituales" when, reflecting on the division of Mind and Nature, he refers to Mind in terms of both Geist and reason ("die Natur in ihrem Gegensatz zum Geiste, zur Vernunft” [686]).

Concordant with the shared glorification of Mind within Christianity and the Enlightenment, ${ }^{924}$ both Naphta and Settembrini reject the human body. Naphta's Pietà and its depiction of tortured flesh, for example, "handle sich um bewußte Emanzipation des Geistes vom Natürlichen, dessen Verächtlichkeit durch die Verweigerung jeder Demut davor religiös verkündet werde" (596). ${ }^{925}$ This essential hostility in Christian dogma towards Eros finds approval in Die Welt als Wille und Vorstellung, in which Schopenhauer notes: "Als die Hauptlehre [des Christentums] [...] finden wir die Empfehlung des echten und reinen Zölibats (diesen ersten wichtigsten Schritt in der Verneinung des Willens)".926 In Der Zauberberg, Settembrini tacitly criticises this Christian rejection of Eros when he jokes that nurse Mylendonk wears a cross where her bosom should be (95), and he claims to despise "[die] Naturfeindschaft" of Naphta's Pietà (597). However, elsewhere Settembrini expresses an antipathy towards the natural body identical to that of Christianity: "[I]nnerhalb der Antithese von Körper und Geist bedeutet der Körper das böse, das teuflische Prinzip, denn der Körper ist Natur, und die Natur - innerhalb ihres Gegensatzes zum Geiste, zur Vernunft, ich wiederhole das! - ist böse, - mystisch und böse.” (378-79; see also 153, 597, 686, 692) Settembrini's view of the natural body as evil recalls Novalis's following claim: "Böse und gute Geister sind gleichsam Stickstoff und Lebensluft. Zum thierischen Leben gehören beyde - und der thierische Körper besteht

\footnotetext{
923 See 2.2, p. 30 .

924 This follows my interpretation of Mind as a concept that straddles Geist/soul and intellect (see 3.5, p. 101).

925 This dualism of body and soul also explains Naphta's rejection of the body and consequent transference of Eros to the Mind (see 5.2, pp. 162-63) as inherently Christian.

${ }^{926}$ Schopenhauer II, p. 789; see also ibid., pp. 717-18, 788, 790, 794. Nietzsche similarly notes the Christian "Todfeindschaft gegen die Sinnlichkeit und Geschlechtlichkeit" (Nietzsche KSA 12, p. 331; see also Nietzsche KSA 4, p. 56).
} 
größtentheils aus bösem Geiststoff."927 Furthermore, the biological reinterpretation of Christian dogma in this passage echoes the relationship between Christian asceticism and Classical thought within Settembrini's ideology.

The amalgamation of Christian asceticism and Enlightenment thought has ramifications for the social microcosm at sanatorium Berghof. Intertextual analysis within this thesis has revealed connections between the views of Naphta and of Novalis (i.e. between Christian dogma and Romanticism), ${ }^{928}$ as well as between the views of Settembrini and of Freud (i.e. between the Enlightenment and the $20^{\text {th }}$ century). ${ }^{929}$ The presence of Christian dogma within Enlightenment ideology consequently signals that asceticism may also have infiltrated $20^{\text {th }}$-century culture. This supposition is confirmed in the chapter section "Forschungen" by the following use of the words "Scham" and "Ekel" to describe life: "Aber wiewohl nicht materiell, war es [das Leben] sinnlich bis zur Lust und zum Ekel, die Schamlosigkeit der selbstempfindlich-reizbar gewordenen Materie, die unzüchtige Form des Seins." (418) The Christian fundament to these concepts of shame and disgust is established by Nietzsche in Also sprach Zarathustra, in which Zarathustra criticises Christian asceticism, declaring: "Aber Scham ist in eurer Liebe und schlechtes Gewissen". ${ }^{930}$ Yet these key words are also used in Der Zauberberg in a specifically $20^{\text {th }}$ century context. Dr Krokowski, for example, argues in the chapter section "Analyse" that modern culture seeks to control Eros by means of "Scham und Ekel" (195). ${ }^{931}$ An intertextual reflection of this equivalence of Christian dogma and $20^{\text {th }}$-century morality can be found in "Die 'kulturelle' Sexualmoral und die moderne Nervosität", in which Freud

\footnotetext{
${ }^{927}$ Novalis 2, p. 531.

928 See, for example, 2.2 , p. 30.

929 See, for example, 2.4 , p. 43.

${ }^{930}$ Nietzsche KSA 4, p. 156. This conflict between Christian morality and Eros is embodied by Dr Krokowski himself: "Mit seinen glühenden Augen, seiner Wachsblässe und seinem schwarzen Bart, dazu den Mönchssandalen über grauwollenen Socken, schien er selbst in seiner Person den Kampf zwischen Keuschheit und Leidenschaft zu versinnbildlichen, von dem er gesprochen hatte." (194) The blend of chastity and passion in this passage recalls Nietzsche's attack of Schopenhauerian asceticism (see 5.1, p. 154), and is further reflected in the conflict between erotic drives and $20^{\text {th }}$-century sexual morality noted by Freud (see, for example, Freud VII, pp. 144-45).
}

${ }^{931}$ See also 5.4, p. 174. 
notes: "[D]ie einzelnen Fortschritte [des kulturellen Triebverzichts] wurden von der Religion sanktioniert". 932

However, the omnipresence of Eros demonstrated in $5.1^{933}$ indicates the failure of Christianity to completely eradicate sensuality. A subsequent conflict between morality and Eros is noted by the narrator in the chapter section "Analyse" (195). This tension mirrors the antithesis of nature/life and morality discussed in texts by Novalis, Schopenhauer and Nietzsche. Arguing in favour of morality, Novalis states: "Das Ideal der Sittlichkeit hat keinen gefährlichern Nebenbuhler, als das Ideal der höchsten Stärke - des kräftigsten Lebens" ${ }^{934}$ Schopenhauer similarly declares: "Die Natur kennt nämlich nur das Physische, nicht das Moralische: sogar ist zwischen ihr und der Moral entschiedener Antagonismus". ${ }^{935}$ Nietzsche, on the other hand, protests that sexual morality is unnatural, ${ }^{936}$ and Freud warns in the essay "Der Mann Moses und die monotheistische Religion" (1937): "Ethik ist [...] Triebeinschränkung". 937

The conflict between Eros and morality has significant consequences for humanity. As the narrator notes in the chapter section "Analyse":

Dieser Widerstreit zwischen Keuschheit und der Liebe [...], wie gehe er aus? Er endige scheinbar mit dem Siege der Keuschheit. Furcht, Wohlanstand, züchtiger Abscheu, zitterndes Reinheitsbedürfnis, sie unterdrückten die Liebe, hielten sie in Dunkelheiten gefesselt, ließen ihre wirren Forderungen höchstens teilweise, aber bei weitem nicht nach ihrer ganzen Vielfalt und Kraft ins Bewußtsein und zur Betätigung zu. Allein dieser Sieg der Keuschheit sei nur ein Schein- und Pyrrhussieg, denn der Liebesbefehl lasse sich nicht knebeln, nicht vergewaltigen, die unterdrückte Liebe sei nicht tot, sie lebe, sie trachte im Dunklen und Tiefgeheimen auch ferner sich zu erfüllen, sie durchbreche den Keuschheitsbann und erscheine wieder, wenn auch in verwandelter, unkenntlicher Gestalt... (195)

\footnotetext{
932 Freud VII, p. 150.

933 See pp. 153-54.

934 Novalis 2, p. 576.

935 Schopenhauer II, p. 723.

${ }^{936}$ Nietzsche KSA 6, pp. 307, 310; see also Nietzsche KSA 5, p. 363.

${ }^{937}$ Freud XVI, p. 226; see also Freud VII, pp. 137, 139.
} 
This description of repressed Eros and its expression in transfigured form selectively parallels Freud's theory that repressed drives find alternative forms of expression. ${ }^{938}$ Freud's idea is anticipated by Schopenhauer, who claims: "[I]m Menschen [wird der Wille zum Leben] [...] mit so vieler Erkenntnis überkleidet und zudem durch die Fähigkeit der Verstellung verhüllt [...], daß sein wahres Wesen fast nur zufällig und stellenweise zum Vorschein kommt". ${ }^{939}$ Yet in Der Zauberberg, Eros appears in one particular form: disease. This pathological transfiguration of Eros is recognised by Dr Krokowski, who declares in the chapter section "Analyse": "Das Krankheitssymptom sei verkappte Liebesbetätigung und alle Krankheit verwandelte Liebe" (196). Krokowski's hypothesis concurs highly referentially with Freud's belief that repressed sexual drives can express themselves as neurosis, ${ }^{940}$ an idea once again pre-empted by Schopenhauer, who states: "In jenem Widerstreben des Willens, das ihm Widrige in die Beleuchtung des Intellekts kommen zu lassen, liegt die Stelle, an welcher der Wahnsinn auf den Geist einbrechen kann." ${ }^{941}$ The specifically psychological consequences of sexual repression noted in these texts are confirmed in Der Zauberberg by Settembrini, who believes that the Enlightenment thinker Leopardi succumbed to mental atrophy because he was celibate (153). ${ }^{942}$ Similarly, in an ironic modification of Krokowski's hypothesis, Peeperkorn's mental anguish ${ }^{943}$ originates in "d[er] entsetzliche[n] Schande der Gefühllosigkeit, de[m] Ohnmacht, das Weib zur Begierde zu wecken" (912).

At sanatorium Berghof, the expression of Eros as psychological disease is modified in the idea that repressed Eros can cause epileptic seizures. This is graphically illustrated by Herr Popów in the chapter section "Totentanz":

Der Lehrer Popów [...] erwies sich [...] als epileptisch, in dem er einen krassen Anfall dieser Art erlitt, mit jenem Schrei, dessen dämonischer und

\footnotetext{
${ }^{938}$ Freud X, p. 335.

${ }^{939}$ Schopenhauer I, p. 230.

${ }^{940}$ Freud X, p. 335; see also Freud XIII, p. 56. See 5.4, p. 172.

${ }^{941}$ Schopenhauer II, p. 516; see also M. Zentner, op. cit., p. 47.

${ }^{942}$ Leopardi's fate clearly relates to Freud's belief that, for many people, “die Erkrankungsmöglichkeit [beginnt] [...] erst mit der Abstinenz” (Freud VIII, p. 323; see also Freud VII, pp. 156-57).

${ }^{943}$ See 2.5 , p. 59.
} 
außenmenschlicher Charakter oft geschildert worden ist, zu Boden stürzte und neben seinem Stuhle unter den scheußlichsten Verrenkungen mit Armen und Beinen um sich schlug. (453)

The erotic nature of Popów's episode is revealed by the description of his seizure as a "wüste Offenbarung und mysteriöse[r] Skandal" (454), and the narrator immediately recalls an earlier lecture given by Krokowski, in which epilepsy is described as “Äquivalent der Liebe und Orgasmus des Gehirns" (454). These statements reflect the Romantic view of epilepsy as sexual, ${ }^{944}$ a notion that appears to have directly influenced Freud. Not only does Freud similarly associate epilepsy with Eros (“[d]er hysterische Krampfanfall ist ein Koitusequivalent”), ${ }^{945}$ but he clarifies this by linking epilepsy to neurosis and consequently to the transfigured expression of Eros. ${ }^{946}$

Although Freud's texts noted above support the interpretation of Popów's physical seizure as a product of psychological disease, Dr Krokowski's thesis that the sanatorium patients' tuberculosis has a psychological origin (196) is a bold claim mitigated only partially by the description of the Berghof patients as "innerlich krank" (69) (which infers the drives of the psyche). However, the reader's knowledge of texts by Freud and Novalis that establish strong links between psychological and physical pathology helps to explain and validate Krokowski's idea. Freud, for example, equates repressed sexual drives with pathological toxins, ${ }^{947}$ and his description of drive repression as "[eine] Stauung"948 is strikingly similar to Novalis's belief that the origin of all disease is an obstruction ("Kranckheit [entsteht] [...] aus einer Stockung"). ${ }^{949}$ Of particular interest is Novalis's conviction that the mind can pathologically influence the body: "Die Seele ist unter allen

\footnotetext{
${ }^{944}$ P. Widdess-Walsch; B. Mostacci; P. Tinuper; O. Devinsky. "Psychogenic nonepileptic seizures", in S. Hermann and W. Theodore (eds.). Epilepsy part I. Handbook of Clinical Neurology, vol. 107. Amsterdam: Elsevier BV, 2012, pp. 277-95, here, p. 277.

${ }^{945}$ Freud VII, p. 239.

${ }^{946}$ Freud XIII, p. 270.

${ }^{947}$ See 5.4, p. 177.

${ }^{948}$ Freud XI, p. 436; see also Freud XIII, p. 273.

${ }^{949}$ Novalis 2, p. 561; this passage is also quoted in 3.4 (see p. 92).
} 
Giften das Stärckste. Sie ist der durchdringendste, diffusibelste Reiz". ${ }^{950}$ This fragment is reflected particularly clearly in Der Zauberberg in the narrator's following observation from the chapter section "Fragwürdigstes": "Wer im organischen Krankheitssymptom ein Werk aus dem bewußten Seelenleben verbannter und hysterisierter Affekte erblickt, der anerkennt die Schöpfermacht des Psychischen im Materiellen” (992). The referential connection of both this passage and Krokowski's hypothesis of disease to Novalis's and Freud's work links the Romantic concept of the mind's power over the body to the $20^{\text {th }}$ century.

The description of the sanatorium patients as "innerlich krank" (69), mentioned above, dialogically opposes Nietzsche's claim in Die Geburt der Tragödie that the German people conceal "eine herrliche, innerlich gesunde, uralte Kraft". ${ }^{951}$ Indeed, such national health is revealed to be an illusion in Der Zauberberg by Castorp, who insists that deathaffirming Romantic German music is "das Gemütlich-Gesundeste auf der Welt" (989). Instead, the diseased "essence" of the sanatorium patients appears to affirm Nietzsche's concept of decadence as pathological (“die Verwesung”). ${ }^{952}$ In 2.4 and 4.3, I demonstrated that decadence as it is portrayed in Der Zauberberg is caused by the continued affirmation of Romantic, Christian views of death within the $20^{\text {th }}$ century. ${ }^{953}$ This argument is enriched by the reader's knowledge of the ascetic fundament to $20^{\text {th }}$-century culture discussed above, in conjunction with Nietzsche's conviction that Christian morality, i.e. the negation of Eros, is the cause of the decadent imbalance between culture and nature. ${ }^{954}$ Accordingly, the reader of Der Zauberberg can conclude not only that the persistence of Christian asceticism within the $20^{\text {th }}$ century has led to the prevalence of psychological and physical disease at sanatorium Berghof, but also that this disease is indicative of social degeneration.

\footnotetext{
${ }^{950}$ Novalis 3, p. 464; also quoted by Käte Hamburger (K. Hamburger, op. cit, p. 68); see also Novalis 2, p. 628.

951 Nietzsche KSA 1, pp. 146-47.

952 Nietzsche KSA 6, p. 312.

953 See 2.4, pp. 43-44, 45; 4.3, p. 119.

${ }^{954}$ Nietzsche KSA 6, p. 310; see also ibid., p. 307.
} 


\subsection{Civilisation and the diseased body}

The pathological power of the mind discussed in the previous subchapter convinces Dr Krokowski of the secondary nature of both disease and the body. In the chapter section "Ewigkeitssuppe und plötzliche Klarheit", he consequently declares of Castorp's tuberculosis: “[D]iese feuchte Stelle da [...] ist für mich eine sekundäre Erscheinung... Das Organische ist immer sekundär...” (291; see also 554). ${ }^{955}$ The subordinate position of the body expressed in this passage referentially parallels the metaphysics of Novalis and Schopenhauer. Novalis, for example, claims that the world is an expression of the self, "a priori von mir belebt - Eins mit mir". ${ }^{956}$ Schopenhauer similarly believes that the body is experienced by the individual "durch die Erkenntnis, nur in der Vorstellung, d.h. nur im Gehirn". ${ }^{957}$ These texts align Dr Krokowski's conception of the body and of disease with Romanticism, an alignment confirmed by the Pietà's (mediaeval yet associated with Romanticism) ${ }^{958}$ sadistic exploitation of the human "Fleischesschwäche" (594). ${ }^{959}$ The Pietà's torture of the flesh indicates furthermore that Krokowski's Romantic view of the body is rooted in the Christian ascetic "Verachtung gegen die Gebrechlichkeit von Körper" noted by Nietzsche..$^{960}$

Yet Settembrini similarly rejects the body following its tendency towards disease (153-54, 377, 380-81). This compatibility of views underscores the interrelation of Christian Romanticism and Enlightenment thought established in 6.1. ${ }^{961}$ A further link

\footnotetext{
${ }^{955}$ Ironically reflecting his own convictions, Krokowski materialises before Castorp in the chapter section "Ewigkeitssuppe und plötzliche Klarheit" "als sei er durch die Lüfte gekommen" (290). Krokowski actually enters Castorp's room through the balcony door.

${ }^{956}$ Novalis 2, p. 554.

${ }^{957}$ Schopenhauer I, p. 51. The message presented by Novalis's and Schopenhauer's texts is illustrated in Der Zauberberg by a rift between representation and original noted by the narrator, who claims that Madame Chauchat's portrait is "als Bildnis seinem Gegenstande nur weitläufig verwandt" (390; see also 391, 411).

${ }^{958}$ See 2.4 (pp. 41-49). In this subchapter, I establish the interrelation of Christianity, the motif of the Middle Ages, and Romanticism.

959 The human "Fleischesschwäche" depicted in the Pietà is wittily reflected in Naphta's own lack of physicality ("so miekerig und leibarm" [620]), as well as in his physical hideousness (562-63). Naphta's antithesis to the body is mocked within the primary text by his childhood nickname (before his conversion to life-denying Christianity) "Leib" ("body") (663).

${ }^{960}$ Nietzsche KSA 3, p. 61.

${ }^{961}$ See 6.1, pp. 183-85.
} 
between Christian Romanticism and the $20^{\text {th }}$ century is made in Der Zauberberg when the narrator compares Krokowski's causality of Mind, body and disease with Castorp's reading of biology in the chapter section "Forschungen":

[D]er eine [Castorp] [ist] auf seinem Bildungswege dazu gelangt [...], die Materie als den Sündenfall des Geistes, als eine schlimme Reizwucherung desselben aufzufassen, während der andere [Krokowski], als Arzt, den sekundären Charakter organischer Krankheit zu lehren gewohnt ist. (554)

Although the position of disease varies slightly, the body is secondary in both conclusions. Castorp, for example, has learnt that organic matter is a disease of Mind, i.e. that disease and Mind precede the body. Krokowski, on the other hand, argues that Mind is first, the body and disease second. This subtle repositioning of disease leads to tension between the conception of disease as a creative (erotic) force equivalent to God, ${ }^{962}$ and Krokowski's idea that disease is a mere consequence of organic matter and Mind.

This latter idea that disease is secondary is challenged in Der Zauberberg when physical disease is shown to incapacitate the mind. In the chapter section "Notwendiger Einkauf", for example, Settembrini rejects the idea that disease can promote intellectuality (153), ${ }^{963}$ an idea upheld within the primary text by the ability of disease to cause semiconscious and unconscious states. ${ }^{964}$ These passages in the novel relate to Freud's claim in "Jenseits des Lustprinzips" that the organism's preoccupation with defending the site of physical trauma results in a decrease in mental function ("psychische[r] Leistung”). ${ }^{965}$ In Der Zauberberg, the incapacitation of the intellect by disease is shown to allow the erotic drives expression. Thus, Popów's unconscious seizure is "wild[] und zweideutig[]" (828), and Castorp's repressed homosexual desire is released while semiconscious in the chapter section "Hippe" (187-89; see also 285). ${ }^{966}$ These expressions

\footnotetext{
962 See 3.4, pp. 97-98; 5.2, p. 163.

963 See 3.5, pp. 100-05. Settembrini's stance negates Nietzsche's belief that decadence (disease) causes an increase in mental activity (see 3.3, pp. 87-88; 3.5, p. 100; 4.6, p. 138).

${ }^{964}$ See also 3.3 , p. 88.

965 Freud XIII, p. 30.

966 See 3.3, pp. 88-89. A semiconscious state also enables Castorp's erotic vision of Chauchat in the chapter section "Forschungen" (433). Similarly, Castorp's feelings of lust in the chapter section "Satana macht
} 
of Eros within unconscious and semiconscious states induced by disease pathologically reconfigure Freud's claim that dreams enable "die verdrängten Libidokomponenten ihre Befriedigung [zu] finden". 967

The negation of the intellect by disease and the consequent expression of the erotic drives deepens the divide between Mind and body. This is illustrated when, soon after his arrival at the sanatorium, Castorp experiences unpleasant physical symptoms that appear to be independent of his mind (111). The role of disease in the emancipation of Castorp's body is clarified by Settembrini's following statement in the chapter section "Notwendiger Einkauf':

In der Regel ist es der Körper, der überwuchert, der alle Wichtigkeit, alles Leben an sich reißt und sich aufs widerwärtigste emanzipiert. Ein Mensch, der als Kranker lebt, ist nur Körper, das ist das Widermenschliche und Erniedrigende, - er ist in den meisten Fällen nichts Besseres als ein Kadaver... (153-54; see also 700)

The ability of disease to emphasise the body is shared by death. Thus, in the chapter section "Die große Gereiztheit", Castorp ruminates on the aggression between Herr Wiedemann and Herr Sonnenschein, ${ }^{968}$ and realises with horror "daß am Ende aller Dinge nur das Körperliche blieb, die Nägel, die Zähne” (1061).

The body without an intellect is essentially animal, as the following description of a man eating in the chapter section "Natürlich, ein Frauenzimmer!" demonstrates:

[Er] schnitt alles, was er sich auf den Teller häufte, im Voraus zu einem Brei und Gemengsel zusammen; dann beugte er sich darüber und schlang, indem er zuweilen mit der Serviette hinter die Brille fuhr, um sich die Augen zu wischen, - man wußte nicht, was da zu trocknen war, ob Schweiß oder Tränen. (118) ${ }^{969}$

\footnotetext{
ehrrührige Vorschläge" are "ungeheuer viel stärker" (142) in his dream than while awake, a fact of which the narrator disapproves, claiming: [D]er wachende Mensch ist besser als der träumende" (365; see also 244).

${ }^{967}$ Freud V, p. 127 (footnote 2).

968 See 4.6, p. 138.

969 This passage reiterates the diseased emphasis on the body noted in 5.4 (see p. 171).
} 
This animality is further associated in Der Zauberberg with the erotic. Herr Miklosich, for example, is described by Frau Stöhr as a sexual predator (“ein Raubtier" [117]), ${ }^{970}$ and Peeperkorn is similarly gripped by lust for womankind: "[Peeperkorn] zeigte sich verliebt in all und jede erreichbare Weiblichkeit, wahllos und ohne Ansehen der Person" (865). Although this lust can be seen to reflect Peeperkorn's general enthusiasm for life, texts by Schopenhauer and Freud explain Peeperkorn's lack of selection as characteristically animal. ${ }^{971}$ According to Schopenhauer, the choice of a mate is a human quality, whereas animals sate their lust "ohne merkliche Auswahl". ${ }^{972}$ Freud similarly traces inconsistency in the choice of sexual object to the animal nature of the unconscious drives. ${ }^{973}$ This last text suggests that Peeperkorn's disease has allowed his animal drives uninhibited expression.

Animal physicality is further linked in Der Zauberberg to the visual perception of objects. The stereoscope in the drawing room, for example, reveals photographs of a Venetian gondolier "in starrer und blutloser Körperlichkeit" (129). The rotating cinemascope shows two men fighting, a schoolmaster beating a pupil, an acrobat jumping on a tightrope, and a rustic couple dancing (129-30). The equivalence of physicality and visuality is also apparent in a scene from the chapter section "Totentanz", in which the cinema audience is shown transfixed by images of aggression and sexuality:

Es war eine aufgeregte Liebes- und Mordgeschichte, die sie sahen, stumm sich abhaspelnd am Hofe eines orientalischen Despoten, gejagte Vorgänge voll Pracht und Nacktheit, voll Herrscherbrunst und religiöser Wut der Unterwürfigkeit, voll Grausamkeit, Begierde, tödlicher Lust und von verweilender Anschaulichkeit, wenn es die Muskulatur von Henkersarmen zu besichtigen galt, - kurz, hergestellt aus sympathetischer Vertrauheit mit den geheimen Wünschen der zuschauenden internationalen Zivilisation. (480)

\footnotetext{
${ }^{970}$ Castorp subsequently dreams that Herr Miklosich carries Frau Stöhr away in his jaws (141).

${ }^{971}$ Wehsal's debasement to the level of an animal (see 5.4, p. 175), on the other hand, is tempered by his love of Chauchat's individual soul (934).

972 Schopenhauer I, p. 198.

${ }^{973}$ Freud VIII, p. 90.
} 
The erotic nature of visuality in this passage reflects Schopenhauer's note that members of the opposite sex scrutinise one another to determine sexual compatibility. ${ }^{974}$ Freud similarly declares: "Der optische Eindruck bleibt der Weg, auf dem die libidinöse Erregung am häufigsten geweckt wird". ${ }^{975}$ This erotic visuality is combined with the animal physicality discussed above in the following cinematic images from "Totentanz" of a young Moroccan woman: “[D]ie strotzende Brust war halb entblößt, [...] [i]hre Nüstern waren breit, ihre Augen voller tierischen Lebens" (481).

Erotic animal visuality is further established in Der Zauberberg as antithetical to culture. Chauchat's manner of observation is "ziemlich rücksichtslos und zudringlich" (191), and in the chapter section "Gedankenschärfe", Castorp's behaviour is similarly antisocial:

Hans Castorp betrachtete die beiden [Russen] mit einer Rücksichtlosigkeit, die ihm sonst fremd war und die er selbst als brutal empfand; doch war es eben das Brutale daran, das ihm plötzlich ein gewisses Vergnügen verursachte. Seine Augen waren zugleich stumpf und zudringlich. (107-08) $)^{976}$

Castorp's pleasure in his own brutality is reminiscent of Freud's belief that cruelty and voyeurism are related. ${ }^{977}$ Furthermore, Freud is convinced that voyeurism is usually controlled by shame, i.e. by morality (“[d]ie Macht, welche der Schaulust entgegensteht und eventuell durch sie aufgehoben wird, ist die Scham (wie vorhin der Ekel)"). ${ }^{978}$ Castorp and Chauchat's obvious lack of shame consequently underscores the idea that vision is opposed to culture.

The reason behind this opposition of vision and culture can be found in a divide between vision and language. Thus, in the chapter section "Forschungen", Castorp's scientific reading is superceded by a vision of Chauchat, and whereas Settembrini the

\footnotetext{
974 Schopenhauer II, p. 702.

${ }^{975}$ Freud V, p. 55.

976 This antisocial behaviour is prompted by Eros: Castorp recently heard these Russians making love in the room next to his own. Castorp's staring is reiterated by the cinema audience in the chapter section "Totentanz" (480-81).

${ }^{977}$ Freud V, p. 66. This reiterates the relation of cruelty to lust discussed in 5.4 (see pp. 172-74).

${ }^{978}$ Freud V, p. 56.
} 
linguist resists the lure of death and disease $(98-99,155)$, the fundamentally negative Director Behrens devotes himself to the visual arts (painting and the "photography" of radiology [96]). The emphasis on visuality at the expense of language appears linked to the environment of disease at the sanatorium. This is suggested by Frau Stöhr's speech, which is peppered with "Bildungsschnitzer" (451), as well as by Castorp's habit of speaking to Madame Chauchat in French, a language "parler sans parler" (511) (“ein Sprechen ohne zu sprechen" [transl. 1089]). ${ }^{979}$ As Castorp declares to Chauchat in the chapter section "Walpurgisnacht": "Parler [...] - Pauvre affaire! Dans l'éternité, on ne parle point." (511) (“Sprechen [...] - eine armselige Sache! In der Ewigkeit spricht man überhaupt nicht!” [transl. 1089]).

The domination of vision over language in Der Zauberberg rather literally interprets Nietzsche's praise of his own writing style as “[eine] Rückkehr der Sprache zur Natur der Bildlichkeit". ${ }^{980}$ This revision of language is related to the concept of "Reaktion als Fortschritt", ${ }^{981}$ with which Nietzsche argues in Menschliches, Allzumenschliches that a regression to barbarism is necessary to renew culture. In subchapter 4.6, I demonstrated that the text of Der Zauberberg rejects Nietzsche's concept of barbarism as antithetical to culture. ${ }^{982}$ This stance is illustrated further in the novel by Settembrini's opposition of "Literatur und Barbarei" (788) in the chapter section "Als Soldat und brav", and by his related claims: "Die Sprache ist die Gesittung selbst” (780); "[n]ur Menschenfeindschaft könne die Wortlosigkeit, die rohe und stumme Dinglichkeit auf ihren Namen taufen.” (78788). ${ }^{983}$ It is interesting to note that Peeperkorn characteristically substitutes speech with gesture $(832,864)$, and the noise of the thundering waterfall in the chapter section "Mynheer Peeperkorn (Schluß)" both drowns out his voice and prohibits the speech of others (938-40). This last scene of formless noise is described as "ein Höllenspektakel"

\footnotetext{
979 Similarly, Castorp fails to write to Chauchat in her absence, reasoning that she is "vom Schreiben entbunden" (535).

${ }^{980}$ Nietzsche KSA 6, p. 344.

981 Nietzsche KSA 2, p. 46.

982 See 4.6, p. 139.

983 Thomas Mann also notes an antithesis of literature and barbarism in Betrachtungen eines Unpolitischen (Mann 13.1, pp. 54-58).
} 
(938), a negative evaluation that, together with Peeperkorn's affiliation with the barbarism of the loss of language, annuls the argument presented by some critics that Peeperkorn presents a positive alternative to the pedagogy of Naphta and Settembrini. ${ }^{984}$

In Der Zauberberg, the interpretation of Nietzsche's "Reaktion als Fortschritt" as a regression to barbarism is aligned with Freud's following claim that disease is regressive: "Das Wesen der Geisteskrankheit besteht in der Rückkehr zu früheren Zuständen des Affektlebens und der Funktion." 985 This idea is reflected with much humour in the chapter section "Er versucht sich in französischer Konversation", in which Castorp catches sight of a dying patient from the hallway, "der langsam seine sehr großen Augäpfel zur Tür []rollt" (164). Deeply impressed by this experience, Castorp mimics the dying man by widening and rolling his own eyes as he goes on his way along the corridor (164). ${ }^{986}$ Yet Castorp's childishness is challenged by Settembrini's conviction that regression to the (Romantic, Christian) glorification of death is a form of disease that has infiltrated modernity ("das Weltbild selbst, die Geistesepoche" [989; see also 305]). Thus, the text of Der Zauberberg indirectly associates Nietzsche's "Rückkehr der Sprache zur Natur der Bildlichkeit" and "Reaktion als Fortschritt" with decadence, and argues that the ability of disease to undermine language also endangers civilisation.

\subsection{Erotic freedom, decadence and gender}

The thematic discussion of the erotic, diseased body and its domination of the intellect and of civilisation continues in Der Zauberberg in the portrayal of disease as lascivious. In the chapter section "Natürlich, ein Frauenzimmer!", Frau Stöhr establishes the ambiguity of the rest cure ("[der] horizontalen Daseinsform" [487]) when she reports that someone switched off the light in the common solarium the evening before, "zu Zwecken, die Frau Stöhr als 'durchsichtig' bezeichnete" (116). Moreover, the suspected perpetrator Herr Miklosich was sighted leaving Frau Wurmbrandt's room at four o'clock in the morning the

\footnotetext{
${ }^{984}$ See, for example, K. Wolff. "Dem Tod keine Herrschaft einräumen - Peeperkorn als Humanist," in R. Wolff (ed.). Aufsätze zum Zauberberg. Bonn: Bouvier Verlag, 1988, pp. 91-113, here, p. 109.

985 Freud X, pp. 337-38.

${ }^{986}$ Herr Albin's posturing (see 4.4, pp. 125-27), as well as the man who throws a tantrum because his tea is too cold (see 4.5, p. 133), also ironically illustrate this regression to childishness.
} 
previous Tuesday (117). Lasciviousness at the sanatorium is also illustrated by Madame Chauchat, following an intertextual connection that reveals Eros within the most unlikely habit. In the chapter section "Frühstück", Chauchat is introduced to both Castorp and the reader when she slams the glass door of the dining room $(72$; see also 118,169$) .{ }^{987}$ This action selectively parallels a passage from Die Welt als Wille und Vorstellung, in which Schopenhauer discusses the Shakers' rejection of loud noises including the slamming of doors ("wie Schreien, Türenwerfen, Peitschenknallen, starkes Klopfen u.s.w."). ${ }^{988}$ Considering Schopenhauer's corresponding note of the Shakers' aversion to erotic relations, the reader can surmise that Chauchat opposes Christian asceticism; and indeed, the text of Der Zauberberg hints that Chauchat has affairs not only with Castorp and Peeperkorn, but also with Director Behrens $(392,396)$.

The lasciviousness prevalent at sanatorium Berghof can be interpreted according to texts by Novalis, Schopenhauer and Nietzsche as a negative, modern phenomenon. In "Glauben und Liebe", for example, Novalis laments the contemporary emphasis on sensuality, ${ }^{989}$ and in Die Welt als Wille und Vorstellung, Schopenhauer condemns the current spread of atheist hedonism as "Bestialismus". ${ }^{990}$ Nietzsche further links modern sensuality to decadence in his attack of the modern (Wagnerian) "SinnlichkeitsEpidemie". 991 This last text deepens the reader's understanding of the sanatorium patients' eager reception of Dr Krokowski's risqué lecture series (191-92), allowing the enthusiastic response of these patients to be interpreted as an attraction to the stimulus of Eros that reconfigures the decadent craving for entertainment and intoxication discussed in subchapter 4.4. ${ }^{992}$ Nietzsche also criticises the ascetic priests ("[die] Ärzte der Seele"

\footnotetext{
987 See also 5.1, p. 152.

988 Schopenhauer II, p. 804. E. Joseph also traces this passage in Der Zauberberg to the following fragment by Nietzsche: "die Tür werfen" (Nietzsche KSA 10, p. 347, quoted in E. Joseph, op. cit., p. 39), and there is even a biographical origin reported by Katja Mann in Meine ungeschriebene Memoiren (Frankfurt am Main, 1974, p. 63, noted by E. Joseph, op. cit., p. 39).

${ }^{989}$ Novalis 2, pp. 494-95.

990 Schopenhauer II, p. 592.

${ }^{991}$ Nietzsche KSA 13, p. 601.

992 See 4.4 (pp. 119-28); see also 5.2, p. 158.

993 Nietzsche KSA 3, p. 56.
} 
read: Dr Krokowski) for incurring in their worshippers an agitation that soon leads to exhaustion. ${ }^{994}$ This sequence was established in 4.2 and 4.4 as typical of decadence; ${ }^{995}$ in the context of Krokowski's lectures, it consequently appears that Eros is one of the intoxicating substances responsible for decadent exhaustion.

Concordant with this association of lasciviousness with decadence, freedom from morality is shown in Der Zauberberg to oppose life. This idea is explored in the chapter section "Neckerei, Viatikum. Unterbrochene Heiterkeit", in which Castorp and Joachim are passed while walking by a group of young patients, "barhaupt und braun, die Damen in farbigen Sweaters, die Herren meist ohne Überzieher und selbst ohne Stöcke, wie Leute, die ohne Umstände und die Hände in den Taschen ein paar Schritte vors Haus machen.” (78) Joachim attempts to explain this casual impression:

'Gott', sagte er, 'sie sind so frei... Ich meine, es sind ja junge Leute, und die Zeit spielt keine Rolle für sie, und dann sterben sie womöglich. Warum sollen sie da ernste Gesichter schneiden. Ich denke manchmal: Krankheit und Sterben sind eigentlich nicht ernst, sie sind mehr so eine Art Bummelei, Ernst gibt es genaugenommen nur im Leben da unten. (81)

Joachim's reasoning indicates that disease exempts sufferers from the seriousness and responsibility of life, and consequently relates selectively and referentially to the following passage from "Nietzsche contra Wagner": "Krankheit ist jedes Mal die Antwort, wenn wir unsrem Recht auf unsre Aufgabe zweifeln wollen, wenn wir anfangen, es uns irgendworin leichter zu machen." ${ }^{996}$ Here, Nietzsche formulates a critical response to Schopenhauer's theory that insanity is an attempt to avoid painful reality, ${ }^{997}$ an idea that anticipates Freud's assertion in "Die Abwehr-Neuropsychosen" (1894): "Man ist also berechtigt zu sagen, daß das Ich durch die Flucht in die Psychose die unerträgliche Vorstellung abgewehrt hat". 998

\footnotetext{
994 Ibid; Nietzsche KSA 13, p. 218.

995 See 4.2, pp. 109-10; 4.4, pp. 127-28.

${ }^{996}$ Nietzsche KSA 6, p. 433.

${ }^{997}$ Schopenhauer II, p. 516; see also M. Zentner, op. cit., pp. 54-55.

${ }^{998}$ Freud I, p. 73; also quoted in M. Zentner, op. cit., p. 54.
} 
The concept of disease as an evasion of life's trials explains the prevalence of "unernster Liederlichkeit" (455) 999 at the sanatorium. Hermione Kleefeld, for example, wears a trouser suit, "darin sie nach dem Essen mit gespreizten Knien in einem Korbsessel der Halle recht liederlich lümmelte" (713). Moreover, a young lady engaged to be married is rumoured to have recently emerged from Herr Einhuf's private room 'bekleidet nur mit einem Pelz, unter dem sie nichts weiter als eine Reformhose getragen haben sollte” (450). In the chapter section "Politisch verdächtig!", the portrayal of unserious lasciviousness continues in a scene suggestive of oral intercourse. Here, a girl, her breathing ragged due to asthma, is shown leaning over a boy's lap in order to sew a button onto the knee of his trousers (175-76). The sexual connotations of this position are reiterated in the boy's own behaviour; as the girl sews, he coughs and puts his fingers to his mouth, an action that suggests the pairing of object and orifice. Freud condemns such erotic activity because he believes it to negate the serious, life-affirming purpose of sexual relations:

Die sogennanten perversen Arten des Verkehrs zwischen beiden Geschlechten, bei denen andere Körperstellen die Rolle der Genitalien übernehmen, [...] sind ethisch verwerflich, da sie die Liebesbeziehungen zweier Menschen aus einer ernsten Sache $\mathrm{zu}$ einem bequemen Spiele ohne Gefahr und ohne seelische Beteiligung herabwürdigen. ${ }^{1000}$

Similarly, Schopenhauer is convinced that love (i.e. procreation) is a serious matter, ${ }^{1001}$ and Nietzsche praises "d[ie] Ehrfurcht vor dem Werdenden". ${ }^{1002}$ The sanctity of procreation expressed in these texts is reflected in Der Zauberberg in the chapter section "Fragwürdigstes", in which the spirit medium Elly Brand's writhing and panting under hypnosis is criticised as "[eine] skandalöse Niederkunft" (1029).

The negation of life inherent to non-procreative sexual relations is compounded in Der Zauberberg by the fact that tuberculosis sufferers are frequently rendered infertile by

\footnotetext{
${ }^{999}$ It appears that fun is linked to disease (459); Settembrini's inability to smile is consequently linked to his affirmation of life (366).

${ }^{1000}$ Freud VII, p. 163.

${ }^{1001}$ Schopenhauer II, pp. 682-85; see also ibid., p. 702.

1002 Nietzsche KSA 3, p. 323.
} 
their illness. ${ }^{1003}$ This infertility can be seen to have contributed to the sanatorium patients' lasciviousness. Both Schopenhauer and Freud, for example, believe that infertility can increase sexual interest, ${ }^{1004}$ a positive effect on libido that Freud traces to the elimination by infertility of "der Angst vor den Folgen des Geschlechtverkehres". ${ }^{1005}$ Freud also establishes the diseased nature of infertile lasciviousness by claiming that the primary, pleasurable aim of libido is adjusted during puberty to become compatible with procreation. ${ }^{1006}$ This suggests that the salacious behaviour of the sanatorium patients is regressive, a form of sexuality linked furthermore to neurosis by Freud, who claims: "[D]ie Sexualität der Psychoneurotiker [hat] den kindlichen Standpunkt bewahrt [...] oder [ist] auf ihn zurückgeführt worden". ${ }^{1007}$ Freud's psychoanalytic theory thus informs the scandalous combination of diligent school pupils and orgiastic experimentation suggested in the chapter section "Satana macht errührige Vorschläge" when a group of young patients retire to study the erotic book Die Kunst, zu verführen, "gemeinsam [...] auf verschiedenen Zimmern" (141). ${ }^{1008}$

The sanatorium patients' sterility, together with their physical disease, psychological disease and substance abuse, ${ }^{1009}$ is further indicative of decadence when interpreted according to Nietzsche's following statement:

\section{Folgen der décadence.}

Das Laster, die Lasterhaftigkeit

die Krankheit, die Krankhaftigkeit

das Verbrechen, die Criminalität

das Coelibat, die Sterilität

der Hysterismus, die Willensschwäche, der Alkoholismus

\footnotetext{
1003 E. E. Petersen. Infektionen in Gynäkologie und Geburtshilfe: Lehrbuch und Atlas. Stuttgart: Georg Thieme Verlag, 2003, p. 165; A. M. Jequier. Male Infertility: A Clinical Guide. Cambridge: Cambridge University Press, 2011, p. 219.

${ }^{1004}$ Schopenhauer II, p. 691.

${ }^{1005}$ Freud VII, p. 157; see also Freud V, p. 116.

${ }^{1006}$ Freud VII, p. 151; see also Freud V, p. 33.

1007 Freud V, p. 76.

${ }^{1008}$ Freud similarly considers masturbation to be a form of autoeroticism and thus related to neurosis (Freud VII, p. 163).

${ }^{1009}$ See 3.1, pp. 72-73; 4.2 (pp. 108-14); 4.4 (pp. 119-28); 4.5 (128-35); 6.1, pp. 187-89.
} 
der Pessimismus

der Anarchismus

die Libertinage $[\ldots] .{ }^{1010}$

The highly selective parallel between this fragment and Der Zauberberg suggests that the patients' varying forms of malaise may be intended to reflect the degenerate nature of European society in general. ${ }^{1011}$ In addition, the specific association of Eros with decadence in Nietzsche's text quoted above is complemented by further texts from the work of Novalis, Nietzsche and Freud that trace the origins of lasciviousness to society. Paradoxically, it seems that sexual restraint encourages libido. Thus, Novalis notes: "Rohes Vergnügen - consonirtes (beschränktes - mangelhaftes) Vergnügen - gebildetes Vergnügen. (Alle Beschränckung ist Beraubung - Ihre Folge höhere Reitzbarkeit [...] (Asthenie))". ${ }^{1012}$ In his discussion of Christian asceticism, Nietzsche similarly observes: "Bekanntlich wird die sinnliche Phantasie durch die Regelmässigkeit des geschlechtlichen Verkehrs gemässigt, ja fast unterdrückt, umgekehrt, durch Enthaltsamkeit oder Unordnung im Verkehre entfesselt und wüst."1013 This text anticipates Freud's conviction, expressed in "Die 'kulturelle' Sexualmoral und die moderne Nervosität", that abstinence can increase libido. ${ }^{1014}$ The link between erotic repression and pronounced libido in these texts discussed above underscores the idea expressed within Der Zauberberg that Christian asceticism is responsible for modern decadence. ${ }^{1015}$

Whereas the predatory Herr Miklosich mentioned above is a lone figure, the examples of female lasciviousness in Der Zauberberg are numerous. Hermione Kleefeld lounging with her knees apart and the lady with the fur coat and control underwear were mentioned earlier. ${ }^{1016}$ Similarly, Frau Salomon wears a low-cut blouse for Director

\footnotetext{
${ }^{1010}$ Nietzsche KSA 13, p. 255.

1011 This decadence is humorously illustrated in the chapter section "Walpurgisnacht" when the sanatorium patients' attempts to draw a pig blindfolded produce only monsters with features and tails in unnatural places (502).

1012 Novalis 3, p. 304.

1013 Nietzsche KSA 2, p. 134; see also Nietzsche KSA 3, pp. 73-74.

${ }^{1014}$ Freud VII, pp. 156-57; see also Freud XIV, p. 147.

1015 See 6.1, p. 189.

1016 See above, pp. 199.
} 
Behrens' benefit (116), and Frau Redisch's physical charms (specifically her large bosom) nearly ensnare Castorp's uncle when he comes to visit (659-61). The knowing looks ("schräge[] Blicke[]" [172]) of Dr Krokowski's female patients indicate their familiarity with the erotic, and even the dreadful Frau Stöhr is not exempt: at the mention of Herr Miklosich, she breaks out in a sweat (117). These examples of female sexuality in Der Zauberberg negate the assumption of both Schopenhauer and Freud that men are more sexually active than women. ${ }^{1017}$ This discrepancy is partially explained in the primary text by the eager reception of Die Kunst, zu verführen, a little book that introduces the female patients to ideas about their own sexuality. Herr Magnus strongly disapproves of the fact that his wife has read the pamphlet, "denn dergleichen 'verhätschele' die Frauen und bringe ihnen unbescheidene Begriffe bei” (413). The corruptive power of this particular piece of literature is further illustrated in the chapter section "Forschungen", in which Castorp witnesses Die Kunst, zu verführen being passed (by a boy with decaying fingernails) to a young girl recently delivered to the sanatorium by her mother (414).

This corruption of female sexual innocence at the sanatorium is compounded by the association of overt female sexuality with prostitution. The sanatorium, for example, is described by Settembrini as "[ein] Lustort[]" (131), and Director Behrens declares soon after Castorp's arrival: “[Castorp] wird sich schon amüsieren. Damenmangel ist auch nicht, - allerliebste Damen haben wir hier. Wenigstens von außen sind manche ganz malerisch.” (74); “"[u]nd dann die Damen, herrje, die Damen! Bunt wie die Paradiesvögel, sag ich Ihnen, und mächtig galant..." (163). Moreover, in the chapter section "Fragwürdigstes", the young spirit medium Elly Brand is dressed by Krokowski as a sacrificial virgin in a simple white shift dress and no underwear (1019). The atmosphere at this séance reminds Castorp of the first time he visited a brothel (1017-18); following this connection to prostitution, Castorp's disapproval of séances (996-97) suggests that the pronounced sexuality of the female sanatorium patients is similarly immoral. This idea concurs with both Novalis's damning

\footnotetext{
${ }^{1017}$ Freud VII, pp. 157-58; Schopenhauer II, p. 693. Although Madame Chauchat's affairs (despite being married) with Behrens, Castorp, and Peeperkorn clearly challenge the status quo, this can be explained according to her representation of the masculine discussed in 5.1 (see pp. 148-49).
} 
view of prostitution ${ }^{1018}$ and Schopenhauer's conviction that female infidelity, and by association, multiple sexual partners, is both unnatural and morally wrong. ${ }^{1019}$

The criticism of decadent female sexuality in Der Zauberberg is augmented by an ironic portrayal of lesbianism. Fräulein Engelhart, for example, is clearly enamoured of Madame Chauchat: “[']Madame Chauchat [...] ist so lässig. Eine entzückende Frau.' Und dabei verstärkte sich die flaumige Röte auf Fräulein Engelhardts Wangen um eine Schattierung" (119). In another example, an Egyptian princess habitually dresses in a man's jacket and trousers, "[und] von der Männerwelt nichts wissen wollte, sondern ihre zugleich träge und heftige Huld ausschließlich einer rumänischen Jüdin zuwandte" (827). ${ }^{1020}$ Yet significantly, the male equivalent of lesbianism, homosexuality, is not portrayed as decadent. Dialogically opposing Freud's view of narcissistic love (of which homosexuality is an example) as unhealthy, ${ }^{1021}$ the primary text conspicuously avoids any link between homosexuality and disease. Chauchat's representation of the homosexual (Hippe), for example, is distinct from her embodiment of disease, which is a form of stimuli linked to female Eros. ${ }^{1022}$ Instead, the text of Der Zauberberg associates homosexuality positively with culture. This can be seen in the chapter section "Schnee", in which Castorp's vision of harmonious civilisation is introduced by the sight of "[eines] schöne[n] Knabe[n]" (743), whose beauty is linked to homosexuality. ${ }^{1023}$ Furthermore, the boy's relation to civilisation is underscored by the decent, pleasant expression on his face, which gives way to deadly seriousness when he sees the witches' temple symbolic of barbarism (743-44). ${ }^{1024}$ The interrelation of homosexuality and civilisation in Der Zauberberg corresponds selectively to Freud's belief that homosexual urges are particularly suitable for diversion into

\footnotetext{
1018 Novalis 2, p. 491.

${ }^{1019}$ Schopenhauer II, p. 693. Nevertheless, Schopenhauer argues in favour of concubines for the convenience of the male (Schopenhauer V, pp. 730-32).

1020 This lascivious princess gifts Director Behrens his erotically decorated coffee grinder (397) (see 5.2, p. 156). The description of the Jewish lover quoted above hints that the Egyptian princess is based on the American writer Gertrude Stein, whose long-term lover was the Jewish author Alice B. Toklas.

${ }^{1021}$ Freud XI, p. 436.

1022 See 5.3, pp. 165-66.

1023 See the connection between the aesthetic and homosexuality established in 5.1, pp. 148-49.

1024 This follows the relation of the witches" "Blutmahl" $(746,747)$ to Nietzsche's barbaric Dionysus (see 2.5 , p. 52).
} 
culture. ${ }^{1025}$ However, the partial negation of homosexuality noted in 5.1 and $5.4^{1026}$ continues, in accordance with Freud's negative opinion of pronounced homosexuality, ${ }^{1027}$ in the portrayal of Castorp and Chauchat/Hippe as bisexual rather than exclusively homosexual. ${ }^{1028}$

\subsection{The power of immoral lust and disease over moral life}

The theory behind the antithesis of decadent female Eros and culturally-affirming homosexuality is explored in Der Zauberberg in the chapter section "Enzyklopädie". Here, Settembrini reconfigures the opposition of Mind and Nature as an antipathy between humanity and lust (380; see also 381). In the chapter section "Schnee", Castorp modifies this idea by opposing love with both lust and death (748), thereby suggesting that his concept of love equals Caritas, or the moral love of humanity. Although clearly outweighed by the lasciviousness of the female sanatorium patients discussed in $6.3,{ }^{1029}$ Caritas is present towards the end of the novel after Chauchat returns to the sanatorium in the company of her new lover (Peeperkorn) (827). Considering Schopenhauer's claim that the loss of the beloved is "ein Schmerz, der jeden andern übersteigt", ${ }^{1030}$ the reader is surprised by both Castorp's acceptance of this new turn of events and his eagerness to forge a friendship with his rival (853-54). An explanation for Castorp's apparent lack of jealousy is provided by Novalis, who declares in the "Teplitzer Fragmente": "Liebe ohne Eifersucht ist nicht persönliche Liebe [...] - man kann Vernunftliebe sagen - denn man liebt hier nicht, als Person, sondern als Glied der Menschheit - Man liebt die Rivale mehr, wie den Gegenstand." 1031 This definition of Caritas is explored further in Der Zauberberg when Chauchat and Castorp vow friendship with one another for the sake of the beloved (Peeperkorn): "Wollen wir Freundschaft halten, ein Bündnis schließen für ihn [...]! Gibst

\footnotetext{
${ }^{1025}$ Freud VII, pp. 152-53.

1026 See 5.1, p. $154 ; 5.4$, pp. 177-78.

${ }^{1027}$ Freud VII, p. 153.

1028 See 5.1, pp. 148-49.

1029 See 6.3, pp. 201-03.

${ }^{1030}$ Schopenhauer II, p. 706.

${ }^{1031}$ Novalis 2, p. 615.
} 
du mir darauf die Hand?" (906) Castorp's acceptance of Chauchat's offer indicates a progression from erotic infatuation with the individual to impersonal love that reflects Schopenhauer's praise of Caritas in Die Welt als Wille und Vorstellung. ${ }^{1032}$

However, the denial of life associated with Schopenhauer's praise of Caritas ${ }^{1033}$ is opposed in Der Zauberberg by the morality of the life-affirming characters Joachim and Settembrini. Joachim, for example, is portrayed as serious and honourable (814), and he declares to Castorp in the chapter section "Totentanz": "Schlappheit und Gehenlassen kann ich natürlich [...] nicht leiden, Disziplin muß sein.” (446) ${ }^{1034}$ Similarly, Settembrini is “[a]nständig[]" (156) and "[s]tandhaft[]" (766), and "sei auf eine lebengebundene und bürgerliche Sittlichkeit eingeschworen" (703). ${ }^{1035}$ The life and morality embodied by these characters appears at first glance to reflect Nietzsche's belief that morality developed out of the organic drive to survive; ${ }^{1036}$ however, this is incompatible with the antithesis of amoral nature and morality established earlier. ${ }^{1037}$ Instead, the combination of life and morality selectively recalls Novalis's following claim: "Das Leben ist ein moralisches Prinzip". ${ }^{1038}$ Novalis's text indicates that the moral life represented by Joachim and Settembrini is a construct distinct from nature.

Yet this separation from nature means that morality is essentially artificial. The subsequent impotence of morality against the power of nature is illustrated in the chapter section "Operationes spirituales", in which Naphta argues that the determinism of the world renders morality in vain (695). ${ }^{1039}$ Naphta's claim is upheld in Der Zauberberg in Castorp's shallow "moral" satisfaction ("moralische[r] Genugtuung" [382-83]) at saving two hundred cigars while being confined to his bed with a cold, and in his dubious version of charity in

\footnotetext{
${ }^{1032}$ Schopenhauer II, pp. 771-72, 781.

1033 Ibid.

1034 Joachim's moral stance in life dissolves in death, and his usually serious and honourable expression ("ernst und ehrbar") degrades post-mortem into a smile (814) (see also 2.5, p. 54).

1035 Peeperkorn also affirms life; however, his animal lust (see 6.2, p. 193) establishes his essential immorality.

1036 Nietzsche KSA 10, p. 405.

1037 See 6.1, p. 186.

1038 Novalis 3, p. 285; also quoted in K. Hamburger, op. cit., p. 60.

${ }^{1039}$ In subchapter 3.2, I demonstrated that human actions are determined by external and internal stimuli, i.e. by natural forces (see pp. 73-79).
} 
the chapter section "Totentanz", which consists of gifting flowers to dying patients in the hope that he will be invited to visit (448). ${ }^{1040}$ These examples of weak morality selectively parallel Schopenhauer's pessimistic note of “[der] seltenen und schwachen Spuren von Moralität". ${ }^{1041}$ In fact, Schopenhauer observes a prevalence of negative traits such as "giftige[n] Neid und teuflische Schadenfreude"; ${ }^{1042}$ similarly, Nietzsche declares: "Der Mensch ist gegen sich selber das grausamste Tier". ${ }^{1043}$ This negative view of human nature leads Nietzsche to conclude: "[D]ie ganze Moral ist eine beherzte lange Fälschung", ${ }^{1044}$ an idea that anticipates Freud's conviction that humans are essentially amoral, their behaviour controlled only by cultural pressures, for example by "Lohn und Strafen", ${ }^{1045}$ and by "soziale[r] Angst". 1046

However, these cultural pressures are largely absent at the sanatorium, and this leads to the gradual dissipation of Castorp's morality during his stay. On his arrival, Castorp reacts with disgust after learning that Krokowski psychoanalyses the patients ("[d]as ist ja widerlich!" [20]); however, he is observed three chapters later disappearing into the darkness of Krokowski’s analytical "Grube” (556). Similarly, Castorp is initially disturbed by the animal sounds of his Russian neighbours coming through the wall of his room (6364), ${ }^{1047}$ and feels uneasy at the thought of Chauchat's impending X-ray that will reveal "das Innere ihres Körpers" (325). He reacts in both situations with "einer ehrbaren Verfinsterung seiner Miene" (325), an expression that appears in Der Zauberberg consistently in connection with an aversion to death or Eros (see also 47, 63, 169-70). Yet after a few months at the sanatorium, Castorp easily dismisses his pang of conscience at the thought of spending Christmas at the sanatorium (Christmas is symbolic of family and of life in

\footnotetext{
1040 See also 2.4, p. 46. Castorp refers to "de[m] Fall auf Nummer fünfzig" (475), i.e. he depersonalises the dying, and his "charitative Teilnahme" (477) includes the insensitive action of taking the dying Karen Karstedt to visit the cemetery (see 2.3 , p. 38; 2.4, p. 46).

${ }^{1041}$ Schopenhauer II, p. 821.

1042 Ibid., p. 820.

${ }^{1043}$ Nietzsche KSA 4, p. 273.

1044 Nietzsche KSA 5, p. 235.

1045 Freud X, p. 335.

1046 Ibid., p. 330; see also ibid., pp. 331-32.

${ }^{1047}$ See also 6.2, p. 194 (footnote 976).
} 
Hamburg) (408-09), and indulges his interest in amoral (natural) life and immoral death, disease and Eros by secretly ordering textbooks on anatomy, physiology and biology (415). In the chapter section "Mynheer Peeperkorn", the dissolution of Castorp's morality is complete when he reacts with indifference to the fact that his relationship with Chauchat is both immoral and irrational (836).

The absence of morality at the sanatorium is linked to the immoral influence of disease. ${ }^{1048}$ The sanatorium patients, for example, defy sanatorium regulations by sneaking out at night to play poker and petits chevaux in hotels in the town (114). ${ }^{1049}$ Similarly, in the chapter section "“Mein Gott, ich sehe!'”, Castorp is astounded when Madame Chauchat acknowledges him with a smile and a glance despite their lack of formal introduction, "als seien sie überhaupt keine gesellschaftlichen Wesen" (314). ${ }^{1050}$ Chauchat's relaxed behaviour starkly contrasts the conduct of Castorp's female acquaintances in Hamburg, “die aufrechten Rückens den Kopf ihrem Tischherrn zuwandten, indes sie mit den Spitzen der Lippen sprachen" (191). The role of disease in enabling freedom from morality at the sanatorium is explained to Castorp by Chauchat in the chapter section "Walpurgisnacht" (“[c]'est la maladie qui me la rend” (512) (“"d]ie Krankheit gibt sie mir” [transl. 1090; see also 901, 836]). Similarly, Herr Albin first claims that he is incurable, and then declares: “Gönnen Sie mir das bißchen Ungebundenheit, das für mich aus dieser Tatsache resultiert!” (124) This immoral freedom enabled by disease is linked to the erotic: Castorp's thoughts of what it might be like to be Albin make his heart race and give him the same feeling of "wüste[r] Süßigkeit" (125) that he later feels as he dreams of kissing Chauchat on the palm (i.e. on the inside) of her hand (142).

The effect of disease on morality discussed above relates to the nature of the former as a principle of dissolution. This quality of dissolution is shared by death and Eros, ${ }^{1051}$ as Settembrini explains in the chapter section "Vom Gottesstaat und von übler Erlösung":

\footnotetext{
1048 See also 6.2, p. 196.

${ }^{1049}$ Furthermore, the teenage boys dubbed Max and Moritz drink alcohol in the company of women (450), and Herr Einhuf stumbles home drunk every night (450).

1050 Chauchat's unmanicured hands $(119)$ and poor posture $(118,325)$ also indicate her disregard for social form.

${ }^{1051}$ See also 2.5, pp. 52, 54.
} 
[Des Todes] Reich ist das der Wollust. Sie fragen mich, warum der Wollust? Ich antworte Ihnen: weil er löst und erlöst, weil er die Erlösung ist, aber nicht die Erlösung vom Übel, sondern die üble Erlösung. Er löst Sitte und Sittlichkeit, er erlöst von Zucht und Haltung, er macht frei zur Wollust. (620-21)

Settembrini's implied opposition of dissolute death and Eros with the form of morality is anticipated in Castorp's earlier musings on "Form und Freiheit, Geist und Körper, Ehre und Schande, Zeit und Ewigkeit" (589). The essential duality of moral form and immoral dissolution expressed in these passages reflects the antithetical characteristics of Nietzsche's principles of art Apollo and Dionysus. ${ }^{1052}$ Castorp clearly favours the latter: in the chapter section "Humaniora", the association of life with form leads him to frivolously declare: "Wozu die Form erhalten [...]. Form ist ete-pe-tete" (404). ${ }^{1053}$ Castorp's statement reflects a general imbalance between form and dissolution within the primary text. The morality of Settembrini and Joachim, for example, is outweighed by the decadent immorality of the other sanatorium patients, ${ }^{1054}$ and in the chapter section "Schnee", Castorp concludes that morality is powerless against death: "Vernunft steht albern vor ihm [dem Tod] da, denn sie ist nichts als Tugend, er aber Freiheit, Durchgängerei, Unform, und Lust." (748) This domination of morality and reason by death relates to the idea discussed in 6.2 that culture is threatened by disease. ${ }^{1055}$

The dissolution of moral form is explored further in the chapter section "Walpurgisnacht", in which the guests not only annul their identity as individuals by wearing masks, but also ignore the civilised (i.e. moral) distance between individuals and

\footnotetext{
1052 See also 2.5, pp. 51-52. Thus, morality is related to the discussion of life as tension (see 2.5, pp. 52-53).

1053 Castorp's affirmation of death is also apparent from his earlier affront at Settembrini's use of the word "virtue":

Ganz ohne sich zu genieren spricht er [Settembrini] von 'Tugend' - ich bitte dich! Mein ganzes Leben lang habe ich das Wort noch nicht in den Mund genommen, und selbst in der Schule haben wir immer bloß 'Tapferkeit' gesagt, wenn 'virtus' im Buche stand. Es zog sich etwas zusammen in mir, das muß ich sagen. (156)

${ }^{1054}$ See above, pp. 206-07; 6.3, pp. 196-202.

1055 See 6.2, p. 196.
} 
address one other with "du" (the informal "you") (494-95). The immorality of this "duzen" is clear from Settembrini's following statement:

'Hören Sie, Ingenieur, lassen Sie das!' befahl Settembrini mit zusammengezogenen Brauen. 'Bedienen Sie sich der im gebildeten Abendlande üblichen Form der Anrede, der dritten Person pluralis, wenn ich bitten darf! [...]. Das 'Du' unter Fremden, das heißt unter Personen, die einander von Rechtes wegen 'Sie' nenne, ist eine widerwärtige Wildheit [...], ein liederliches Spiel, das ich verabscheue, weil es sich im Grunde gegen Zivilisation und entwickelte Menschlichkeit richtet, - sich frech und schamlos dagegen richtet.['] (497)

This dissolution of cultural values is implicitly linked to Eros when Settembrini claims that "du" is used "um eines ungesitteten Reizes willen" (497); and indeed, Castorp's informal address of Chauchat for the first time in "Walpurgisnacht" can be seen as a step towards their erotic union at the conclusion of the chapter section (504).

However, in "Walpurgisnacht", Madame Chauchat also presents the idea that the dissolute freedom of death and disease is in fact moral:

La morale? Cela t'intéresse? Eh bien, il nous semble, qu'il faudrait chercher la morale non dans la vertu, c'est-à-dire dans la raison, la discipline, les bonnes mœurs, l'honnêteté - mais plutôt dans le contraire, je veux dire: dans le péché, en s'abandonnant au danger, à ce qui est nuisible, à ce qui nous consume. Il nous semble qu'il est plus moral de se perdre et même de se laisser dépérir que de se conserver. Les grands moralistes n'étaient point des vertueux, mais des aventuriers dans le mal, des vicieux, des grands pécheurs qui nous enseignent à nous incliner chrétiennement devant la misère. (515)

(Die Moral? Das interessiert dich? Nun, uns scheint, daß man die Moral nicht in der Tugend suchen darf, also in der Vernunft, der Zucht, den guten Sitten, dem Anstand, - sondern vielmehr in deren Gegenteil, ich meine: in der Sünde, in der Hingabe an die Gefahr, an das Schädliche und Verzehrende. Uns scheint, daß es moralischer ist, sich zu verlieren und selbst zu verderben (sogar sich umkommen zu lassen), als sich zu bewahren. Die großen Moralisten waren nicht tugendhaft, sondern Abenteurer im Bösen, lasterhafte, große Sünder, die uns lehren, uns christlich vor dem Elend zu neigen. [transl. 1093]) 
Chauchat's interpretation of morality as compatible with both sin and disease is strongly reminiscent of Naphta's dogma, ${ }^{1056}$ and this connection allows the reader to recognise metatextual links between Chauchat's statement quoted above and Nietzsche's attack of decadent Christian morality in Jenseits von Gut und Böse, Zur Genealogie der Moral and Ecce Homo. ${ }^{1057}$ In particular, the affirmation of disease within Chauchat's essentially Christian version of morality is negated in Der Zauberberg by Settembrini, whose criticism of pity, a concept associated with the Christian reverence for suffering (679), ${ }^{1058}$ relates selectively to Nietzsche's claim: "Leid und Mitleid sind wesensgleich". ${ }^{1059}$ Settembrini subsequently establishes the opposition of these key elements of Christian dogma to culture when he links Christian compassion to the barbarism of the East $(368,370) .{ }^{1060}$ Thus, the text of Der Zauberberg reiterates both the idea discussed earlier that death and disease threaten society ${ }^{1061}$ and the concept of sanatorium decadence as consequent to Christian morality. ${ }^{1062}$

\footnotetext{
${ }^{1056}$ See 3.4, pp. 94 (footnote 494), 95 (footnote 504).

${ }^{1057}$ Nietzsche KSA 5, pp. 166, 285-86; Nietzsche KSA 6, pp. 307, 352-53, 367-68, 372.

${ }^{1058}$ See also 2.4, p. 47.

1059 Nietzsche KSA 3, pp. 127-30. Similarly: "Diese allgemeine Menschenliebe, in praxi die Bevorzugung aller Leidenden, Schlechtweggekommenen, Kranken" (Nietzsche KSA 13, p. 219; see also Nietzsche KSA 5, pp. 226-27). Nietzsche's attitude is affirmed in Der Zauberberg by Wehsal, who writhes under Castorp's well-meaning advice, complaining: "Ja, da reden Sie mir nun so von oben herab zu [...] [,] und wissen gar nicht, wieviel Unverschämtheit in Ihrem Trost liegt, und daß Sie mich dadurch nur noch tiefer erniedrigen." (932)

${ }^{1060}$ Settembrini consequently associates Chauchat (representative of death) with the East by referring to her "tatarische[] Physiognomie" (438). However, Chauchat has "keinerlei Mitleid" with the pale, nervous Castorp as he approaches her for the first time in the chapter section "Walpurgisnacht" (504). This inconsistancy is explained by Freud's conviction that the opposite of pity is cruelty (Freud V, p. 93), which I established in 5.4 is linked to the erotic (see pp. 172-74). Thus, Chauchat's lack of mercy is consequent to her representation of Eros (see 5.1, p. 145).

${ }^{1061}$ See 6.2, p. 196.

${ }^{1062}$ See also 6.1, p. 189.
} 


\subsection{Synthesis or mediation? Eros, disease and humanity}

Paradoxically, the quality of dissolution inherent to both disease and Eros ${ }^{1063}$ indicates their alignment with change, in affirmation of Novalis's view (adopted from Plato) of love and disease as states of insufficiency that enable transcendence:

Das Herz ist der Schlüssel der Welt und des Lebens. Man lebt in diesem hülflosen Zustande, um zu lieben - und andern verpflichtet $\mathrm{zu}$ seyn. Durch Unvollkommenheit wird man der Einwirckung andrer fähig - und diese fremde Einwirckung ist der Zweck. In Kranckheiten sollen und können uns nur andre helfen. So ist Xstus, von diesem Gesichtspunct aus, allerdings der Schlüssel der Welt. ${ }^{1064}$

Novalis's idea is illustrated on a superficial level in the chapter section "Satana macht ehrrührige Vorschläge", in which Castorp's fever causes a feeling of "ausschweifender Freude und Hoffnung" (137) that is reiterated after he becomes aware of Joachim's love for the Russian girl Marusja (139). These passages and their positive interpretation of disease and love relate further to both Nietzsche's belief in the transcendent qualities of disease $^{1065}$ and his following declaration through the mouthpiece of Zarathustra: "[Die Liebe ist eine] Fackel [...], die euch zu höheren Wegen leuchten soll". ${ }^{1066}$ According to Settembrini's characterisation of the human body as susceptible to both disease and Eros $(153-54,377,380-81),{ }^{1067}$ the body can be interpreted as a medium of this transcendence, an idea underscored by the narrator's following declaration in the chapter section "Walpurgisnacht":

Mais aussi il est une grande gloire adorable, image miraculeuse de la vie organique, sainte merveille de la forme et de la beauté, et l'amour pour lui, pour le corps humain, c'est de même un intérêt extrêmement humanitaire et une puissance plus éducative que toute la pédagogie du monde! ... Oh, enchantante beauté organique

\footnotetext{
1063 See 6.4, pp. 207-09.

1064 Novalis 3, p. 606. Similarly: "Bedürfniß nach Liebe verräth schon eine vorhandene Entzweiung in uns. Bedürfniß verräth immer Schwäche.” (ibid., p. 693; see also ibid., pp. 349, 667; Novalis 2, p. 573).

1065 Nietzsche KSA 3, p. 105.

1066 Nietzsche KSA 4, p. 92.

${ }^{1067}$ See also 6.2, p. 190.
} 
qui ne se compose ni de teinture à l'huile ni de pierre, mais de matière vivante et corruptible, pleine du secret fébrile de la vie et de la pourriture! (519)

(Aber er ist auch eine große anbetungswürdige Herrlichkeit, staunenswertes Bild des organischen Lebens, heiliges Wunder der Form und der Schönheit, und die Liebe zu ihm, zum menschlichen Körper, ist gleichfalls eine höchst humanistische Neigung und eine erzieherischere Macht als alle Pädagogik der Welt! ... Oh, bezaubernde organische Schönheit, die weder aus Ölfarbe noch aus Stein besteht, sondern aus lebender und zerstörbarer Materie, voll des febrilen Geheimnisses des Lebens und der Verwesung! [transl. 1097])

By suggesting that the body's representation of Eros is an essential part of humanity, this passage implies that the goal of transcendence is humanity.

Yet Schopenhauer declares the feelings of transcendence inspired by love to be an illusion, ${ }^{1068}$ and only acknowledges the potential of suffering. ${ }^{1069}$ This particular emphasis on the transcendent function of disease is reflected in Der Zauberberg in the formula "through death to life" introduced in the chapter section "Mynheer Peeperkorn (Des Weiteren)". Here, Castorp expounds to Madame Chauchat on the relationship between life, death and humanity: "[D]er Tod, weißt du, ist [...] das pädagogische Prinzip, denn die Liebe zu ihm führt zur Liebe des Lebens und des Menschen" (903). ${ }^{1070}$ Castorp's idea selectively parallels Novalis's following declaration: “Tod [ist] Mittel zum Leben”. 1071 Nietzsche similarly equates Dionysian destruction with “d[em] Werden", ${ }^{1072}$ and claims that death is valuable for life (“[d]er Werth für das Leben entscheidet zuletzt”). ${ }^{1073}$ This last quoted fragment by Nietzsche anticipates Freud's conviction that the undeniable presence

\footnotetext{
1068 Schopenhauer II, pp. 709-10. Later, Nietzsche similarly negates love's ability to stimulate life as "die Kunst als organische Funktion" (Nietzsche KSA 13, p. 299).

1069 Schopenhauer I, p. 279.

1070 Thomas Mann refers to Der Zauberberg and to this message in the speech "Von deutscher Republik": "[U]nd es könnte Gegenstand eines Bildungsromanes sein, zu zeigen, daß das Erlebnis des Todes zuletzt ein Erlebnis des Lebens ist, daß es zum Menschen führt” (Mann 15.1, pp. 557-58).

${ }^{1071}$ Novalis 2, p. 560. Similarly, a poem from the second part of Heinrich von Ofterdingen reads: "Helft uns nur den Erdgeist binden, Lernt den Sinn des Todes fassen / Und das Wort des Lebens finden" (Novalis 1, p. 354).

1072 Nietzsche KSA 6, p. 313.

1073 Nietzsche KSA 11, p. 506.
} 
of death during war leads to a renewed interest in life. ${ }^{1074}$ However, Castorp's further association of death with the attainment of (moral) humanity (see above) is a fundamentally Romantic idea that corresponds most selectively to Novalis's following claim: “[D]er Weg v[om] Geiste zur Natur [vom Tode zum Leben]. (Der moralische Weg.)”. ${ }^{1075}$

Novalis believes that moral transcendence enabled by disease is divine: “Entstehung der Kranckheit durch Berührung eines stärkern Lebens [God]". ${ }^{1076}$ This idea is reflected in Der Zauberberg in Dr Krokowski's conviction that the origin of disease is "übersinnlichen Wesen[s]" (554-55). Concordant with the erotic response to disease portrayed in the chapter section "Forschungen", Novalis links such pathological communion to Eros:

Vielleicht geschähe eine ähnliche Verwandlung [wie in vielen Märchen], wenn der Mensch das Übel in der Welt liebgewänne - in dem Augenblicke, als ein Mensch die Kranckheit oder den Schmerz zu lieben anfienge, läge die reitzendste Wollust in seinen Armen - die höchste positive Lust durchdränge ihn. Könnte Kranckheit nicht ein Mittel höhrer Synthesis seyn - Je fürchterlicher d[er] Schmerz, desto höher die darinn verborgene Lust. (Harmonie.) Jede Kranckheit ist vielleicht ein notwendiger Anfang der innigern Verbindung 2er Wesen - der nothw[endige] Anfang der Liebe. Enthusiasmus für Kranckheiten und Schmerzen. Tod - eine nähere Verbindung liebender Wesen. ${ }^{1077}$

This passage presents the idea that disease leads to an erotic union with God. Novalis's subsequent equation of the love of heaven with unity ${ }^{1078}$ suggests that this amalgamation of the individual with God is a form of the synthesis of Nature and Mind within Novalis's concepts of the Last Judgement and Second Coming. ${ }^{1079}$ Although these concepts

\footnotetext{
${ }^{1074}$ Freud X, p. 344.

1075 Novalis 3, p. 41.

1076 Ibid., p. 261.

1077 Ibid., p. 389; see also ibid., p. 242. Similarly: "Unbedingte Vereinigung mit der Gottheit ist der Zweck der Sünde und Liebe. Dythiramben sind ein ächt kristliches Produkt." (a dythiramb is a hymn to Dionysus of lusty, sinful excess) (ibid., p. 653).

1078 Novalis 1, p. 153. Whereas relative love is earthly, absolute love is the love of God (Novalis 2, p. 500). This formula is related to Novalis's understanding of disease: "Thätige Liebe - herein und hineinlieben. Sthenische - Asthenische Liebe. Vollkommene Liebe.” (ibid., p. 587); “[h]albe Kranckheit ist Übel - Ganze Kr[anckheit] ist Lust - und zwar Höhere.” (Novalis 3, p. 389).
}

${ }^{1079}$ See 2.6, p. 63. 
essentially affirm death, ${ }^{1080}$ the origins of the synthesis of Nature and Mind can be found in life itself, an example in Der Zauberberg being the portrayal of life's creation in "Forschungen" (433). This life-affirming aspect to the synthesis of Nature and Mind relates to Novalis's conviction that the Second Coming will initiate a new Golden Age (i.e. an ideal humanity). ${ }^{1081}$ Applied within Der Zauberberg, the synthesis of Nature and Mind would resolve several key antitheses, for example life-affirming and death-affirming Classical and Romantic ideals and their expression as civilisation and barbarism, morality and immorality. ${ }^{1082}$

However, synthesis is not attained in the novel. Naphta claims in the chapter section "Noch jemand" that the opposition of body and soul, Nature and Mind, is the core problematic of humanity (601). This claim strongly reflects Novalis's belief that the original harmony of the world has been lost: "So ist die Welt in der That [nur] eine Mittheilung". ${ }^{1083}$ Novalis's theory anticipates Schopenhauer's conviction that individuality is an illusion caused by the division between Will and representative world. ${ }^{1084}$ The true, divided nature of the world leads Novalis to write: "Der Gegensatz von Leib und Geist ist Einer der Allermerckwürdigsten und Gefährlichsten - Große, historische Rolle dieses Gegensatzes." "1085 Novalis's vision of Golden Age that synthesises these elements is merely an expression of hope for the future; similarly in Der Zauberberg, synthesis is shown to be a goal rather than a reality when, in the chapter section "Schnee", Castorp almost immediately forgets his vision of a balance between life and death (751). ${ }^{1086}$

Also undermining the concept of synthesis in Der Zauberberg is the negation within the primary text of Settembrini's Enlightenment humanism. Settembrini's ideology

\footnotetext{
1080 Ibid.

${ }^{1081}$ Novalis 3, p. 520. See also 2.2, pp. 35-36.

1082 The duality of life and death, civilisation and barbarism, morality and immorality is illustrated by the "Sonnenleute" and the witches from Castorp's snow vision (740-45) (see 2.5, pp. 51-52; 6.3, p. 203).

1083 Novalis 2, p. 595.

${ }^{1084}$ Schopenhauer I, pp. 193, 228.

1085 Novalis 3, p. 682. In a reiteration of Naphta's idea, Mann addresses the glorification of death in the speech "Zum 60. Geburtstag Ricarda Huchs" (1925) as a problem that originates in the polarisation of Nature and Mind (Mann 15.1, pp. 775-76; see also G. Wenzel, op. cit., p. 53).

1086 See 2.6, p. 62. Castorp's vision incidently relates to Novalis and Schopenhauer's acknowledgement of prophetic dreams (Novalis 3, pp. 89, 276; Schopenhauer IV, pp. 290-91).
} 
allegedly renders “de[n] Gegensatz von Gott und Natur hinfällig” (602), an idea concordant with his claim that nature is "selber Geist" (565). ${ }^{1087}$ However, this synthesis is annulled by Settembrini's rejection of the natural world in favour of the intellect, ${ }^{1088}$ which actually affirms the divide between Nature and Mind. Moreover, any positive interpretation of Settembrini's synthesis is negated by its essential similarity to Naphta's death-affirming vision of revolution (607). ${ }^{1089}$ This equivalence of Settembrini's and Naphta's syntheses reflects the interrelation of Christian Romanticism and Enlightenment theory established earlier. ${ }^{1090}$ The negative judgement in Der Zauberberg of the continuation of Christian dogma within the Enlightenment and the $20^{\text {th }}$ century ${ }^{1091}$ in turn suggests that the novel may also negate the concept of synthesis.

Indeed, the rejection of synthesis following its association with death-affirming Christian Romanticism is established by the presentation in Der Zauberberg of an alternative concept: mediation. This concept is explored in the chapter section "Schnee", in which Castorp proposes that humanity mediates between life and death:

Der Mensch ist Herr der Gegensätze, sie sind durch ihn, und also ist er vornehmer als sie. Vornehmer als der Tod, zu vornehm für diesen, - das ist die Freiheit seines Kopfes. Vornehmer als das Leben, zu vornehm für dieses, - das ist die Frömmigkeit in seinem Herzen. (748)

Castorp's hypothesis contradicts his conclusion mentioned earlier that Caritas (life) opposes death (748), and thus calls the related opposition of Caritas and lust into question. ${ }^{1092}$ Indeed, the true interrelation of these forms of love ${ }^{1093}$ is revealed by the narrator to reflect the mediating role of humanity:

\footnotetext{
${ }^{1087}$ See also 2.2, p. 29.

1088 See 6.1, pp. 183-84.

${ }^{1089}$ See 2.6, p. 63.

${ }^{1090}$ See 6.1, pp. 182-85.

1091 See 6.1, p. 189.

1092 See 6.4, p. 204.

1093 See also 5.2, pp. 154-55.
} 
Ist es nicht groß und gut, daß die Sprache nur ein Wort hat für alles, vom Frömmsten bis zum Fleischlich-Begierigsten, was man darunter verstehen kann? Das ist vollkommene Eindeutigkeit in der Zweideutigkeit, denn Liebe kann nicht unkörperlich sein in der äußersten Frömmigkeit und nicht unfromm in der äußersten Fleischlichkeit, sie ist immer sie selbst, als verschlagene Lebensfreundlichkeit wie als höchste Passion, sie ist die Sympathie mit dem Organischen, das rührend wollüstige Umfangen des zur Verwesung Bestimmten, - Charitas ist gewiß noch in der bewunderungsvollsten oder wütendsten Leidenschaft. Schwankender Sinn? Aber man lasse in Gottes Namen den Sinn der Liebe doch schwanken! Daß er schwankt, ist Leben und Menschlichkeit [...]. (907-08) ${ }^{1094}$

The humanity associated with the ambiguity of Eros and Caritas once again refutes Christian dogma by undermining the association of the erotic with evil. In fact, Naphta's attack of marriage on the grounds that love is erotic in the chapter section "Mynheer Peeperkorn (Des Weiteren)" (892) indicates a positive connection between Eros/Caritas and culture. This link parallels Nietzsche's belief that culture is based on the sexual drive: "Unsere Triebe und Leidenschaften sind ungeheure Zeiträume hindurch in Gesellschaftsund Geschlechtsverbänden gezüchtet worden". ${ }^{1095}$ Similarly, Freud conceives of the erotic drive as a constructive urge at the heart of culture, ${ }^{1096}$ and Novalis states: "Tanz - Essen Sprechen - gemeinschaftlich Empfinden und arbeiten - zusammenseyn - [...]. Amor ist es, der uns zusammendrückt. In allen obgedachten Functionen liegt Wollust (Sym[pathie]) zum Grund." ${ }^{1097}$ Novalis's further conviction that morality, too, is a constructive principle of civilisation ${ }^{1098}$ underscores the positive view of Eros/Caritas as the basis of culture.

The mediation of humanity between Eros and Caritas, life and death reflects the nature of morality as an artificial construct, ${ }^{1099}$ and calls to mind the rainbow analogy with

\footnotetext{
1094 Krokowski's lectures introduce this concept of love as ambiguous (193).

1095 Nietzsche KSA 9, p. 487.

1096 Freud VII, pp. 149-50; see also Freud XIV, pp. 461-62. Homosexual urges are particularly suitable for cultural sublimation (Freud VII, pp. 152-53 [see 6.3, pp. 203-04]).

1097 Novalis 3, p. 425; see also Novalis 2, pp. 495, 541. Thomas Mann quotes part of this fragment in "Die Stellung Freuds in der modernen Geistesgeschichte" ("Amor ist es, der uns zusammendrückt") (Mann. "Die Stellung Freuds in der modernen Geistesgeschichte”, op. cit., p. 28). Although Mann's use of this passage to highlight the Romantic basis of Freud's theories fails to recognise the link between Eros and culture made by Novalis, he establishes that the essence of humanity is lustful love in the speech "Von deutscher Republik" (Mann 15.1, p. 550; see also ibid., p. 548).

1098 Novalis 3, p. 250.

1099 See 6.4, pp. 205-06.
} 
which Schopenhauer depicts the species, an ephemeral vision over the raging waterfall of the endless natural cycle of life and death. ${ }^{1100}$ Castorp's vision of mediating humanity in "Schnee" thus starkly opposes the conclusive synthesis of opposites championed by Settembrini and Naphta. Furthermore, the interpretation of moral humanity in Der Zauberberg as innately fragile is intensified by the novel's World War I context and the associated desecration of culture and morality. ${ }^{1101}$ The text of Der Zauberberg consequently appears to present its post-war readers with the message that fragile humanity must be both protected and nurtured.

\subsection{Conclusion}

This chapter has established that life in Der Zauberberg is portrayed as sinful following its essential eroticism. This judgement reflects the Christian denial of sexuality that is revealed within the primary text to have been perpetuated within the Enlightenment and subsequently within $20^{\text {th }}$-century sexual morality. Intertextual connections to the work of Freud and Schopenhauer give the reader insight into the relationship between the denial of Eros in Der Zauberberg and the portrayal of physical and social malaise, as well as into the role of Christian asceticism in causing the disease and decadence prevalent in modern society. However, the pathological power of the mind over the body is challenged in the novel in the antithetical idea that disease undermines the intellect. This intellectual suppression allows the erotic drives expression, and leads to an emphasis on the physical body that debases human beings to an animal level. In turn, animal physicality is linked to an emphasis on visuality and to the devaluation of language. In clear correspondence with the work of Nietzsche and Freud, the text of Der Zauberberg associates the barbarism consequent to this negation of the intellect/language to the degeneration of culture.

The diseased emphasis on the animal body is also reflected in Der Zauberberg in life-negating lasciviousness. Intertextual connections to the work of Novalis, Nietzsche and Freud explain this degenerate heightened libido as not only decadent but also a consequence of repressive sexual morality. Whereas the decadent lasciviousness within the novel is

\footnotetext{
${ }^{1100}$ Schopenhauer II, p. 617. See 4.3, pp. 116-17; 5.1, p. 151 (footnote 761).

1101 The antithesis of war and culture was established in 4.6 (see pp. 138-39); the amorality of the aggressive drives was discussed in 4.6 (see p. 138).
} 
strongly linked to female Eros, homosexuality is shown to positively contribute to culture, and the consequent opposition of decadent female Eros and homosexuality is related within the primary text to a division between the concepts of lust and Caritas. Morality is consequently portrayed, using the examples of Settembrini and Joachim, as a life-affirming construct; however, the artificiality of moral form means that it is easily undermined by the dissolute freedom of disease and Eros. Pathological dissolution is moreover equated within Der Zauberberg with Christian morality, which is subsequently revealed, in affirmation of Nietzsche's philosophy, to be at the heart of social degeneration.

Paradoxically, the dissolution inherent to Eros and disease is linked to the ability of both to enable transcendence, which in turn is shown within the text of Der Zauberberg to be synonymous with the goal of humanity. This process is related to a concept of "from death to life" that is further associated, via parallels to the work of Novalis, to the synthesis of Nature and Mind discussed in chapter two of this thesis. Nevertheless, the concept of humanity as synthesis is negated by the latter's association with the Romantic, Christian affirmation of death. Accordingly, the text of Der Zauberberg presents an alternative concept of humanity as mediation that is illustrated by the ambiguity of the word "love". 1102 This mediation of humanity between Eros and Caritas, Nature and Mind, life and death reiterates the fragile nature of morality. In the context of war, i.e. of aggression antithetical to culture, delicate humanity appears in need of protection and nurture.

\footnotetext{
1102 This concept of mediation indicates that Thomas Mann ultimately sheds the attachment to (Romantic) synthesis noted in the introduction (see p. xiii).
} 


\section{Conclusion}

The quantity of scholarship on Thomas Mann's Der Zauberberg testifies to the complex nature of the novel and to its abundance of themes that lend themselves to critical analysis. It seems that, far from exhausting the book's potential, analysis of Der Zauberberg leads ever further into a mine of fascinating ideas. However, the predominantly source-critical focus of existing Thomas Mann scholarship fails to accurately classify and measure the results of analysis. This is one of the advantages of the newer field of intertextual theory, which I applied within my thesis to the analysis of Der Zauberberg. By amalgamating selected criteria from the taxonomies of Manfred Pfister and Peter Stocker, I was able to qualitatively and quantitatively examine the presence of intertextual parallels within the primary text. For example, I qualified the connections I identified as metatextual (thematic) or palintextual (quotational), and also quantified these by establishing how selective and referential (reminiscent of a particular passage or theme from the intertext), or how communicative (how clearly they are communicated by the primary text) these connections were. Of interest was my discovery that selective metatextual connections are more common in Der Zauberberg than general metatextual links. This suggests that Thomas Mann's montage technique involved, not a general knowledge of the works of other thinkers, but rather a careful choice of ideas from specific paragraphs and fragments. In subchapter 1.4 of this thesis, I stated my objective to acknowledge both intended and unintended intertextual parallels. ${ }^{1103}$ However, the prevalence of selective connections revealed by my analysis indicates that intentional intertextual references within Der Zauberberg predominate.

Although the thesis was fortunate to build on a wealth of existing scholarship, its original focus meant that secondary literature played a relatively minor role. Of particular note, however, is Käte Hamburger's Thomas Mann und die Romantik. Eine problemgeschichtliche Studie (1932). This study explores the Romantic concepts within Novalis's work, a fundament that allowed me to recognise such concepts even within Novalis's reflections on the work of scientific contemporaries. After identifying the

${ }^{1103}$ See p. 18. 
importance of Novalis's theory of stimuli within Der Zauberberg, secondary literature on Novalis's own source of inspiration, Dr John Brown, provided awareness into the importance of Brown's theory for a great many of Novalis's fragments. This is evident, for example, in fragments on life and disease as well as on the relationship between the individual and God. For this insight I am indebted to the outline of John Brown's theories in essays by John Neubauer ("Dr John Brown and early German Romanticism" [1967]), Nelly Tsouyopoulos (“The Influence of John Brown's Ideas in Germany" [1988]) and Thomas H. Broman (The Transformation of German Academic Medicine, 1750-1820 [2002]). In addition, Marcel Zentner's book Die Flucht ins Vergessen (1995) provided invaluable insights into the interrelation of Schopenhauer's philosophy and Freud's psychoanalytic theory.

Following the amount of research on the significance of Nietzsche's and Schopenhauer's philosophies for Thomas Mann's oeuvre, I approached my analysis with the assumption that intertextual links to these two thinkers in Der Zauberberg would predominate. Although this was upheld to a certain extent by my findings, I noted an interesting imbalance within the novel's examination and incorporation of Schopenhauer's and Nietzsche's theories. For example, whereas only a general outline of Schopenhauer's philosophy (the Will to live and its rejection; the theory of reincarnation) is presented within Der Zauberberg, parallels with the work of Nietzsche are both more specific (i.e. often selective and referential), and include a wider range of ideas. Thus, not only do Nietzsche's Kunsttriebe Apollo and Dionysus play an essential role in Der Zauberberg, but also his critiques of decadent morality and art. This focus on specific ideas from the work of Nietzsche suggests that Thomas Mann re-read Nietzsche's work while writing Der Zauberberg. In particular, my analysis suggests that Mann had Nietzsche's Der Fall Wagner close to hand during the novel's inception.

I also found that psychological ideas from the work of Schopenhauer and Nietzsche are "modernised" within Der Zauberberg through their association with Freud's psychoanalytic theory. This insight confirms Dierks' claim that the work of Schopenhauer and Nietzsche form the philosophical base of Der Zauberberg. ${ }^{1104}$ My findings also concur

${ }^{1104}$ M. Dierks. Studien zu Mythos und Psychologie bei Thomas Mann, op. cit., p. 137. See 1.2, p. 10. 
with Käte Hamburger’s following observation from 1932: “[I]n unseren Tagen einer neuen Blüte der Psychiatrie, der Psychoanalyse, der Erforschung der seelischen Bezirke und der durch die Seele bedingten Störungen des Organismus[,] [regt] sich das Interesse für die Krankheitstheorie der Romantik [...] von neuem". ${ }^{1105}$ In subchapter 1.2, I also noted that Hans Wysling identifies similarities between the drive theories of Schopenhauer, Nietzsche and Freud. ${ }^{1106}$ My analysis expands on Wysling's conclusion by demonstrating that these theories developed by Schopenhauer, Nietzsche and Freud are in fact indebted to the stimuli theory of Novalis. ${ }^{1107}$ These findings confirm and elaborate on Dierks' conviction that Thomas Mann's description of Freudian psychoanalysis as "Naturwissenschaft gewordene Romantik" in the essay "Die Stellung Freuds in der modernen Geistesgeschichte" is due to his reception of Novalis and Nietzsche. ${ }^{1108}$

The significance of Novalis's ideas for Der Zauberberg is reflected in the abundance of allusions to his work within the novel. In Der Zauberberg, Novalis's Romantic affirmation of death is linked to Schopenhauer's metaphysics and then reconfigured in the context of culture using ideas from the work of Nietzsche and Freud. ${ }^{1109}$ These findings concur with Dierks' following claim, mentioned in subchapter 1.2 of the thesis and quoted here: "Novalis wird dort [im Zauberberg] vor allem in seinen lebensmetaphysischen Spekulationen an Schopenhauers Willensmystik angeschlossen". ${ }^{1110}$ However, with the exception of this general theme of death-affirmation, my analysis in fact established that the plethora of intertextual connections in Der Zauberberg to the work of Novalis is independent of Schopenhauer's philosophy. Although I approached the thesis assuming that I would predominantly find intertextual links to Novalis's "Geistliche Lieder" and "Hymnen an die Nacht", this was not the case. In fact, my analysis indicated that Thomas Mann was primarily interested in Novalis's fragments, and that this interest led to his

\footnotetext{
${ }^{1105}$ K. Hamburger, op. cit, pp. 63-64 (note 52). See also 6.1, pp. 188-89.

${ }^{1106}$ H. Wysling. “Thomas Manns Rezeption der Psychoanalyse”, op. cit., pp. 208-09; see also ibid., p. 210. See 1.2, p. 10.

1107 See 2.5 , pp. 60-61; 3.1, p. 70; 3.2, p. 75; 5.4, p. 176.

${ }^{1108}$ M. Dierks. Studien zu Mythos und Psychologie bei Thomas Mann, op. cit., p. 147. See 1.2, p. 10.

${ }^{1109}$ See, for example, 2.2, pp. 32-33; 2.4, pp. 41-45.

${ }^{1110}$ M. Dierks. Studien zu Mythos und Psychologie bei Thomas Mann, op. cit., p. 146. See 1.2, p. 10.
} 
recognition of Novalis's preoccupation with Brown's theory of stimuli. The emphasis within Der Zauberberg on Novalis's theory of stimuli, although roughly compatible with Schopenhauer's metaphysics (the Will can be interpreted as a form of stimulus), ${ }^{111}$ is not reflected in Schopenhauer's work in any detail.

In general, the thesis indicated that intertextual correspondences to the work of Novalis, Schopenhauer, Nietzsche and Freud in Der Zauberberg are used in concordance with the message of the primary text. This affirmation of the intertexts' original meaning is complemented in Der Zauberberg by the use of multiple, related ideas from intertexts that lend the messages presented subtle heuristic shades. In the chapter section "Ewigkeitssuppe und plötzliche Klarheit", for example, the themes of temporal division and unity are enriched by an intertextual dialogue between Schopenhauer's concept of Nunc stans and Nietzsche's ewige Wiederkehr that leads to the reader's recognition of a Romantic glorification of death within life. ${ }^{112}$ However, where the primary text expresses concern about modern society, this agreement between the intertexts is abandoned in favour of dialogic confrontation. Specifically, the essential argument within Der Zauberberg that the continued affirmation of Christian Romanticism within $20^{\text {th }}$-century European culture has led to decadence ${ }^{1113}$ - is clearly informed by an intertextual dialogue between the work of Novalis and Schopenhauer on the one hand, and of Nietzsche and Freud on the other. This dialogue draws on Novalis's "Geistliche Lieder" and "Hymnen an die Nacht", on Schopenhauer's Die Welt als Wille und Vorstellung, on Nietzsche's Jenseits von Gut und Böse, Zur Genealogie der Moral, Der Fall Wagner and Ecce Homo, and on Freud's “Die 'kulturelle' Sexualmoral und die moderne Nervosität” and “Zeitgemäßes über Krieg und Tod".

As stated in the introduction, my analysis of life, death, disease and Eros in Der Zauberberg investigated these themes in both simple and then more complex groupings. ${ }^{1114}$ The results of these investigations follow in a summary analysis. Within the examination of

\footnotetext{
${ }^{1111}$ See 3.1, p. 70.

1112 See 4.3, p. 117.

1113 See 2.4, pp. 43-44, 45; 4.3, p. 119; 6.1, p. 189; 6.4, p. 210.

1114 See pp. xii-xiii.
} 
death, for example, I discovered that it is portrayed in Der Zauberberg as a taboo subject linked to the Romantic, Christian view of death as a mystery. The disparity between this conception of death and atheism corresponds within the novel to the views espoused by the characters of Naphta and Settembrini. Whereas Naphta's Christianity leads to his conviction that death is a mystery, Settembrini regards death as a simple physiological necessity. Yet Settembrini's related idea that death is merely an absence of life is criticised in Der Zauberberg as immoral. This implicit affirmation of Christian Romanticism within the novel is subsequently underscored by the insight that Settembrini's view of death as part of life is actually related to Romantic, Christian concepts of death as rejuvenating and transformational.

The atheist conception of death as an absence of life mentioned above leads Settembrini to argue that the fear of death is unfounded. Nevertheless, the instinctual nature of fear means that it is overcome with difficulty, and composure in the face of death is subsequently linked in Der Zauberberg to moral superiority, in referential affirmation of to the views of Schopenhauer. The fear of death is also negated by a belief in an afterlife, as well as by an unconscious belief in immortality. These attitudes towards death express sympathy with the ideals of Christian Romanticism; however, this bias is challenged by Settembrini, who considers Naphta's Romantic, Christian emphasis on death and the afterlife to be "die greulichste Verirrung des Menschengeistes" (305). Similarly, Hans Castorp's own sympathy with death is called into question by the clearly negative association of Naphta's asceticism with the dissolution of culture presented in texts by Nietzsche. The criticism of Christian Romanticism within Der Zauberberg continues in the portrayal of death as a principle of dissolution that opposes the tension of life. This dissolution is illustrated by Peeperkorn's suicide, an act initially associated positively with self-overcoming that is subsequently clarified as death-affirming. Although the apparent dominance of Romantic, Christian death-affirmation in Der Zauberberg is addressed by Castorp's proposed balance between life and death in the chapter section "Schnee", my analysis demonstrated that this balance is negated by Naphta's synthesis of life and death, in which death conquers life in correspondance to the Christian death-affirmation championed by Novalis. 
The nature of life itself is explored in Der Zauberberg according to the message presented in texts by Freud and Novalis that life is the sum of stimuli and an excitable body. Human beings exemplify this sensitivity, and the patients at sanatorium Berghof and their unusual demand for food and oxygen are used in the novel to illustrate the diseased organism's attempt to substitute its lack of energy by absorbing extra stimulus. Crucially, the thesis established that the tuberculosis patients' symptoms and related actions are closely linked to Novalis's concept of the diseased constitution he terms indirect asthenia.

The relationship of the organism to external stimuli continues in an exploration within the primary text of determinism, whereby the organism's response to its environment is shown via intertextual links to the work of Novalis, Schopenhauer, Nietzsche and Freud to be controlled by the stimulus of psychological drives. Of particular note is Freud's death drive, a psychological interpretation of the Romantic concept of Sympathie mit dem Tode that allows Castorp's tendency to affirm death to be interpreted from a $20^{\text {th }}$-century, scientific perspective. The complete determination of the individual by external and internal stimuli and the intertextual relation of this idea to philosophical standpoints in acceptance of fate explains the pronounced passivity that causes Castorp to remain at the sanatorium for seven years.

The dependence of the organism on stimuli is paradoxically accompanied by the ability of stimuli to harm. Texts by Novalis, Nietzsche and Freud indicate that an inability to process stimuli can lead to disease. This idea is investigated within the primary text in cases of physical and psychological trauma that also closely relate to the theories of neurosis in the work of Freud and Schopenhauer. The cause of disease by stimulus is also modified in Der Zauberberg in the idea that disease itself is stimulating. This links disease to life, an idea explored further in the novel in discussions of ambiguous substances and of disease as inborn, i.e. present within life from its inception. However, the pathology of life can potentially be inverted so that disease becomes a means by which health is attained. This idea is traced in Der Zauberberg, via intertextual parallels with the work of Novalis, Schopenhauer and Nietzsche that establish disease as a principle of enhancement, to the creation of life from the inorganic.

The pathological origin of life is linked in Der Zauberberg to the concept of original sin, and the subsequent affiliation of Mind with disease is explained by the reader's 
knowledge of the work of Novalis, Nietzsche and Schopenhauer as something inherently human. This essentially Romantic concept of disease is challenged in the primary text by Settembrini's conviction that disease has a sociological origin. Examining the specific symptoms of lethargy and tension, the novel once again borrows ideas from Novalis's theory of stimuli to present disease as an aberration of the organism's reception of stimuli. Thus, Novalis's understanding of indirect asthenia explains Castorp's lethargic constitution as a phenomenon caused by excessive stimulus, and texts by Nietzsche and Freud further clarify this malady as characteristic of decadent modern society. The pathological apathy at sanatorium Berghof is also linked to temporal distortion. This recalls Schopenhauer's concept of Nunc stans, Nietzsche's concept of ewige Wiederkehr, and Novalis's and Nietzsche's critique of modern temporal and spatial fragmentation, a complex of intertextual relations that is used within the primary text to question the Romantic affirmation of death.

Boredom is further associated with Novalis's concept of indirect asthenia following the lethargic sanatorium patients' desire for the stimulation of entertainment. Entertainment is subsequently criticised within Der Zauberberg as both diseased and decadent, in accordance with strong intertextual links to Novalis's understanding of indirect asthenia and to Nietzsche's critique of decadent art. The diseased patients' enthusiasm for entertainment is complemented in the novel by their attraction to substances that both stimulate and inebriate. These effects are mirrored in a cycle of stimulus and exhaustion initiated by entertainment that progressively undermines the sanatorium patients' health.

Indirectly asthenic, decadent apathy is joined in Der Zauberberg by the antithetical symptom of irritability, which corresponds to Novalis's understanding of direct asthenia. This irritable state is further linked in the primary text to neurosis and decadence following parallels to the work of Freud and Nietzsche. Although a decadent combination of lethargy and irritability is exhibited by Director Behrens and Hans Castorp, a more significant sequence of lethargy followed by irritability is presented in the chapter sections "Der große Stumpfsinn" and "Die große Gereiztheit". This sequence is explained by the work of Novalis as a progression of disease, which is further reflected in Der Zauberberg in acts of aggression and in the outbreak of war (i.e. death). Such conflict opposes culture, and the suggestion in texts by Novalis and Nietzsche that war can enable cultural renewal is negated 
by the novel's criticism of Nietzsche's related concept of barbarism. Only Castorp's release by military conscription and subsequent portrayal as a leader hint that the hope for European culture expressed by the narrator at the conclusion of the novel may be realised.

The relation of Eros to life is explored in Der Zauberberg via the theme of the female body. This erotic female flesh symbolises life in accordance with the role of the female body to nourish a foetus. Although female Eros is initially represented in the primary text by Madame Chauchat, her androgynous figure, poor posture, and presumed infertility negate the procreative function of the female established by Schopenhauer. Accordingly, Castorp's infatuation with Chauchat appears as a form of homosexual attraction grounded in a link between the Romantic affirmation of death and aesthetics. The consequent antithesis of life and aesthetics leads to the interpretation of the female body as repulsive. However, the text of Der Zauberberg subsequently portrays the human body as both aesthetic and erotic, following its division into beautiful exterior and disgusting erotic inner. This division is complicated by the theme of the transfiguration of Eros within art discussed by Schopenhauer, Freud and Nietzsche, with which the novel ultimately negates both female Eros and homosexuality.

With the relation of female Eros to life, the text of Der Zauberberg expands its concurrence with Novalis's theory of stimuli by presenting a link between Eros and the organism's reception of stimuli. This erotic sensitivity is identified as specifically female, in accordance with texts by Novalis, Schopenhauer, Nietzsche and Freud, and is thus part of a gendered duality within which the male symbolises sexual stimulus and the female the receptive erotic body. However, this heterosexual pairing is complicated by the further association of stimulus with God. Although the homoerotic association of man and God follows a Christian preoccupation with Eros and death, these themes are subsequently realigned in Der Zauberberg via the heathen connotations of "Walpurgisnacht". Here, Madame Chauchat is revealed to be not only representative of life and Eros, but also of disease. The consequent interrelation of life, Eros and disease once again reflects Novalis's theory of stimuli, according to a link established between Chauchat's tubercular lymphatic fluid and Novalis's equation of stimuli with liquid. Following Castorp's infatuation with this diseased body, his erotic encounters with Chauchat in the chapter sections 
"Forschungen" and "Walpurgisnacht" indicate, in affirmation of texts by Novalis, Schopenhauer and Nietzsche, that Eros is a destructive power.

The destructive element to Eros is investigated further in Der Zauberberg in the idea that the erotic feelings of pain and pleasure can be elicited by disease. Thus, Wehsal revels in the agony caused by Chauchat's disdain, a form of self-debasement linked to neurosis that is also illustrated by Castorp's homoerotic sensations while being beaten by a fellow schoolboy. This erotic response to pain suggests that Castorp welcomes destructive male erotic stimulus (Chauchat), an example of the death drive from a homoerotic perspective that once again establishes an antithesis of homosexuality and life.

The erotic response to the death drive is portrayed in Der Zauberberg as a repetition of the creation of life from the inorganic. The original sin of life is thus revealed to be its erotic reception of pathological stimulus. Although this is contrasted within the primary text with Settembrini's conviction that Eros is innocent, Settembrini's stance is subsequently revealed to be an illusion, following the concordance between the Christian denial of Eros and the Enlightenment rejection of the body in favour of the mind. This marriage of Christianity and the Enlightenment has implications for $20^{\text {th }}$-century culture, which is shown to harbour remnants of Christian asceticism. The consequent conflict between morality and Eros leads to the transfigured expression of Eros as disease, and parallels with texts by Freud and Nietzsche enrich the reader's interpretation of the novel by suggesting that the physical malaise and decadence at sanatorium Berghof have been caused by Christian sexual morality.

Although the mind is established within Der Zauberberg as the origin of disease, disease itself is revealed to incapacitate the intellect and thereby allow the erotic drives expression. This emphasis on the animal body is subsequently linked to both visuality and to the debasement of language, which, by association, undermines civilisation. A consequent connection between disease and a regression to Nietzschean barbarism is then equated within the novel with decadence. Characteristic of this decadence at the sanatorium is superficial lasciviousness, which, together with the sanatorium patients' assumed infertility, opposes life by negating the serious, procreative function of sexual relations. In addition, the novel reiterates the rejection of female Eros by linking female sexuality 
(including lesbianism) to decadence, while granting homosexuality a constructive social role, in accordance with the views of Freud.

The dissolution of sexual morality by disease is opposed in Der Zauberberg by the moral principle of life and by the related concept of Caritas. However, the artificial nature of morality means that it is easily undermined by disease, which in turn is explained by Nietzsche's philosophy as linked to death-affirming, decadent Christian morality. However, connections to Novalis's work within the primary text indicate that the dissolution associated with disease and Eros enables transcendence, an idea related to the concept of "through death to life" proposed by Castorp in the chapter section "Mynheer Peeperkorn (Des Weiteren)". Yet a related synthesis between Nature and Mind and its equation with humanity is subsequently negated in Der Zauberberg. Instead, the primary text proposes that humanity is an essentially mediating concept, the fragility of which inspires its protection.

In the introduction, I stated my interest in the relation of philosophy, psychology and sociology within Der Zauberberg. ${ }^{1115}$ As previously noted, the individual works of Novalis, Schopenhauer, Nietzsche and Freud exhibit a multifaceted blend of philosophy, psychology and sociology. This is most clearly illustrated by the work of Nietzsche, whose philosophy is focused in a psychological critique of decadent modern culture. However, the novel also stresses specific angles from the intertexts that are then used in combination. I found, for example, that the novel affirms the message of Novalis's biological fragments in conjunction with Freud's discussion of the biological basis of psychology. ${ }^{1116}$ In another example, the equivalence of Hippe and Madame Chauchat both illustrates Novalis's, Schopenhauer's and Nietzsche's non-linear conceptions of time, as well as Freud's specifically psychological concept of the Wiederholungszwang. ${ }^{1117}$ Thus, the text of Der Zauberberg exploits the similarities between the intertexts to build a matrix of associations between the philosophical, psychological and sociological fields. This often begins with an analysis of physical and psychological disease that is then applied to the critique of culture,

\footnotetext{
1115 See pp. xiii-xiv.

1116 See, for example, 3.1, pp. 68-69.

1117 See 3.3, pp. 88-91.
} 
for example in the novel's contextualisation of Novalis's philosophical views of death, disease and Eros within Nietzsche's critique of decadence. ${ }^{1118}$

During the course of my analysis, I was fascinated to discover a strong dialogue in the primary text between not only Catholicism and atheism, but also between these belief systems and the philosophies of Schopenhauer and Nietzsche. The character of Settembrini, for example, is established in Der Zauberberg as an atheist whose views oppose the Christian dogma espoused by Naphta. ${ }^{1119}$ However, the novel mediates between the affirmation and negation of life inherent in these positions by suggesting Nietzsche's concept of amor fati. ${ }^{120}$ Similarly, the antithetical views of death as final or non-final presented in the primary text are amalgamated in parallels to Schopenhauer's concept of death as the end of the individual self but not of the Will. ${ }^{1121}$ The discourse of the novel thus confirms the complexities of the genre. ${ }^{1122}$ Between the philosophies of Schopenhauer and Nietzsche themselves, I found that Schopenhauerian pessimism was negated in the novel in favour of the life-affirmation championed by Nietzsche. ${ }^{123}$ My analysis also revealed a fascinating amalgamation of Christian dogma and biology. In the portrayal of the creation of life in the chapter section "Forschungen", for example, Genesis is reinterpreted in alignment with Novalis's stimuli theory, and life is subsequently presented as a result of God's stimulation by disease. ${ }^{1124}$

The Christian and atheist views of death in Der Zauberberg are inextricably linked to the portrayal of Romanticism and the $20^{\text {th }}$ century. Thus, the intertextual connection between Naphta's dogma and the work of Novalis and Schopenhauer establishes the former's representation of Romanticism and Catholicism, whereas Settembrini's Enlightenment views largely reflect texts by Nietzsche and Freud and are strongly linked

\footnotetext{
${ }^{1118}$ See, for example, 4.3, pp. 118-19; 4.4, pp. 121-22; 4.5, p. 129; 6.3, pp. 197-98.

${ }^{1119}$ See 2.2, pp. 29-30.

${ }^{1120}$ See 2.4, p. 48.

${ }^{1121}$ See 2.2, pp. 32, 33-34.

${ }^{1122}$ See M. M. Bakhtin. "Discourse in the Novel”, op. cit., p. 261.

${ }^{1123}$ My findings thus support the view of Erkme Joseph that Der Zauberberg represents a move away from the philosophy of Schopenhauer to that of Nietzsche (see E. Joseph, op. cit., p. 319).

${ }^{1124}$ See 3.4, p. 98.
} 
to the $20^{\text {th }}$-century society portrayed in the novel. However, my analysis also exposed fundamental similarities between the views of Naphta and Settembrini that suggest a concordance between Enlightenment thought and Romanticism. This was particularly clear in the interrelation of life and death, ${ }^{1125}$ in the related concept of death as transformational (adapted in Schopenhauer and Nietzsche's concept of reincarnation), ${ }^{1126}$ in the concept of a death drive from the work of all four thinkers, ${ }^{1127}$ and in the rejection of Eros. ${ }^{128}$ This relationship feeds into the fundamental argument of Der Zauberberg, mentioned above, that the continued affirmation of Romanticism within the $20^{\text {th }}$ century is the cause of modern decadence. ${ }^{1129}$

My analysis is an addition to existing scholarship that contributes positively to the interpretation of Der Zauberberg. The intertextual criteria of metatextuality, palintextuality, selectivity, referentiality and communicativity first and foremost served to gauge the relative heuristic value of each intertextual connection. This use of intertextual methodology allowed me to identify numerous links within the primary text to the work of Novalis, Schopenhauer, Nietzsche and Freud, and revealed a web of meaning that exceeded my expectations in its complexity and significance. My analysis indicated that knowledge of these intertexts significantly enhances the reader's understanding of Der Zauberberg and its dynamic discussion of life, death, disease and Eros in the context of $20^{\text {th }}$-century culture.

During the process of analysis, I was often confronted with difficult choices as I discovered fascinating intertextual connections that went beyond the scope of the thesis. For example, I touched only briefly on the themes of the sensitive artist and of the aesthetic, ${ }^{1130}$ yet these themes are in fact discussed in depth by Novalis, Schopenhauer, Nietzsche and Freud. In particular, the themes of the artist and disease could be investigated further in another context, following its relation not only to the stimuli theories already examined in this thesis, but also to the discussion of disease in general in the work of

\footnotetext{
1125 See 2.2, pp. 34-36.

1126 See ibid., pp. 33-36.

1127 See 2.5, pp. 60-61.

1128 See 6.1, pp. 183-85.

${ }^{1129}$ See 2.4, pp. 43-44, 45; 4.3, p. 119; 6.1, p. 189; 6.4, p. 210.

${ }^{1130}$ See 4.5 , pp. $131-32 ; 5.1$, pp. $149-54$.
} 
Nietzsche and Freud. Of interest is also the parallel association of the artist with morality in texts by Novalis, Schopenhauer and Nietzsche. Claudia Gremler has investigated Hans Castorp's function as an artist figure in her study of the intertextual relations between Thomas Mann's ouevre and the works of the Danish author Hermann Bang. ${ }^{1131}$ However, the theme of the artist in Der Zauberberg in relation to the constellation of thinkers examined in the present thesis has not yet been the subject of analysis. I propose this as a task for the future that promises to be of significant heuristic value to the further interpretation of Der Zauberberg.

${ }^{1131}$ C. Gremler, op. cit., p. 172. 


\section{Select Bibliography}

\section{Primary sources}

\section{a) Thomas Mann}

Mann, Thomas. Die Briefe Thomas Manns. Regesten und Register, vols. I-V. Hans Bürgin, Hans Otto Mayer and Yvonne Schmidlin (eds.). Frankfurt am Main: S. Fischer Verlag, 1977-1982.

Mann, Thomas. "Die Stellung Freuds in der modernen Geistesgeschichte". In Die psychoanalytische Bewegung, vol. 1. Wien: Internationaler Psychoanalytischer Verlag, 1929, pp. 3-32.

Mann, Thomas. Thomas Mann Briefe, vols. I-III. Erika Mann (ed.). Frankfurt am Main: S. Fischer Verlag, 1978.

Mann, Thomas. Thomas Mann. Gesammelte Werke in Einzelbänden. Leiden und Größe der Meister. Peter de Mendelssohn (ed.). Frankfurt am Main: S. Fischer Verlag, 1982.

Mann, Thomas. Thomas Mann. Gesammelte Werke, vol. XI. Peter de Mendelssohn (ed.). Frankfurt am Main: S. Fischer Verlag, 1984.

Mann, Thomas. Thomas Mann. Große Kommentierte Frankfurter Ausgabe. Werke-Briefe - Tagebücher. Heinrich Detering, Eckhard Heftrich, Hermann Kurzke, Terence J. Reed, Thomas Sprecher, Hans R. Vaget and Ruprecht Wimmer (eds.). Frankfurt am Main: S. Fischer Verlag, 2002.

Mann, Thomas. Thomas Mann. Notizbücher, vols. 1-2. Hans Wysling and Yvonne Schmidlin (eds.). Frankfurt am Main: S. Fischer Verlag, 1991.

Mann, Thomas. Thomas Mann. Schriften und Reden zur Literatur, Kunst und Philosophie, vol. 2. Hans Bürgin (ed.). Frankfurt am Main: S. Fischer Verlag, 1968-1987. 
Mann, Thomas. Thomas Mann. Selbstkommentare: Der Zauberberg. Hans Wysling (ed.). Frankfurt am Main: S. Fischer Verlag, 1993.

\section{b) Novalis}

Novalis. Novalis Schriften. Die Werke Friedrich von Hardenbergs, vols 1-5. Paul Kluckhohn and Richard Samuel (eds.). Stuttgart: W. Kohlhammer Verlag, 1983.

\section{c) Arthur Schopenhauer}

Schopenhauer, Arthur. Arthur Schopenhauer. Sämtliche Werke, vols. I-V. Wolfgang Frhr. von Löhneysen (ed.). Stuttgart/Frankfurt am Main: Suhrkamp Verlag, 1986.

\section{d) Friedrich Nietzsche}

Nietzsche, Friedrich. Friedrich Nietzsche. Kritische Studienausgabe (KSA), vols. 1-15. Giorgio Colli and Mazzino Montinari (eds). München: Deutscher Taschenbuch Verlag, 1999.

\section{e) Sigmund Freud}

Freud, Sigmund. Sigmund Freud. Gesammelte Werke, vols. I-XVIII. Anna Freud, Edward Bibring, Willie Hoffer, Ernst Kris and Otto Isakower (eds.). Frankfurt am Main: S. Fischer Verlag, 2008.

Freud, Sigmund. "Über Coca". In Centralblatt für die gesammte Therapie, vol. 2. Vienna: M. Perles Verlag, 1884, pp. 289-314. http://vlp.mpiwg-

berlin.mpg.de/library/data/lit29488/index_html?pn=13\&ws=1.5; online resource accessed 2 April 2013.

\section{Secondary sources}

Allen, Graham. Intertextuality: the New Critical Idiom. London: Routledge, 2000.

Angelides, Steven. A History of Bisexuality. Chicago: University of Chicago Press, 2001. 
Bade, James. "Ein unveröffentlichter Brief Thomas Manns an Otto Grautoff”. In Jahrbuch der Deutschen Schillergeschellschaft, vol. 39. Stuttgart: A. Kröner Verlag, 1995, pp. 8086.

Bade, James. "The Magic Mountain of Weimar Politics: the Impact of the Assassination of Walther Rathenau on Thomas Mann's Der Zauberberg." In Monatshefte für deutschsprachige Literatur und Kultur, vol. 106, no. 1. Madison: University of Wisconsin Press, 2014, pp. 37-53.

Bakhtin, Mikhail Mikhaĭlovich. "Discourse in the Novel". In Michael Holquist (ed.), Caryl Emerson and Michael Holquist (transl.). The Dialogic Imagination. Four Essays by M. M. Bakhtin. Austin: University of Texas Press, 1981, pp. 259-422.

Bakhtin, Mikhail Mikhaŭlovich. "Epic and Novel”. In Michael Holquist (ed.), Caryl Emerson and Michael Holquist (trans1.). The Dialogic Imagination. Four Essays by M. M. Bakhtin. Austin: University of Texas Press, 1981, pp. 3-40.

Bakhtin, Mikhail Mikhaĭlovich. "From the Prehistory of Novelistic Discourse". In Michael Holquist (ed.), Caryl Emerson and Michael Holquist (transl.). The Dialogic Imagination. Four Essays by M. M. Bakhtin. Austin: University of Texas Press, 1981, pp. 41-83.

Bakhtin, Mikhail Mikhaĭlovich. Problems of Dostoyevski’s Poetics. Caryl Emerson (transl. and ed.). Minneapolis: University of Minnesota Press, 1999.

Barthes, Roland. "The Death of the Author". In Image-Music-Text. Stephen Heath (transl. and ed.). New York: Hill and Wang, 1977, pp. 142-48.

Beharriell, Frederick J. “"Never without Freud': Freud's Influence on Mann”. In Kenneth Hughes (ed.). Thomas Mann in Context. Worchester, Mass.: Clark University Press, 1978. 
Bertram, Ernst. Nietzsche. Versuch einer Mythologie. Berlin: Bondi Verlag, 1919.

Beßlich, Barbara. Faszination des Verfalls: Thomas Mann und Oswald Spengler. Berlin: Akademie Verlag, 2002.

Brandes, Georg. Hauptströmungen der Literatur des neunzehnten Jahrhunderts, vol. 2: Die romantische Schule in Deutschland. Berlin: Reiss Verlag, 1924.

Broman, Thomas H. The Transformation of German Academic Medicine 1750-1820. Cambridge: Cambridge University Press, 2002.

Bynum, William F. “The rise of science and medicine 1850-1913”. In The Western Medical Tradition 1800 to 2000. Cambridge: Cambridge University Press, 2006, pp. 111-240.

Cerf, Steven. "Georg Brandes' View of Novalis: A Current within Thomas Mann's Der Zauberberg”. In Colloquia Germanica, vol. 14. Tübingen: A. Francke Verlag, 1981, pp. $114-29$.

Dierks, Manfred. "Doktor Krokowski und die Seinen. Psychoanalyse und Parapsychologie in Thomas Manns Zauberberg". In Thomas Sprecher (ed.). Das Zauberberg Symposium. Thomas-Mann-Studien, vol. 11. Frankfurt am Main: Vittorio Klostermann Verlag, 1995, pp. 173-96.

Dierks, Manfred. Studien zu Mythos und Psychologie bei Thomas Mann: an seinem Nachlass orientierte Untersuchungen zum 'Tod in Venedig', zum 'Zauberberg' und zur 'Joseph'-Tetralogie. Bern: A. Francke Verlag, 1972.

Dierks, Manfred. “Thomas Mann und die Tiefenpsychologie”. In Helmut Koopmann (ed.). Thomas Mann Handbuch. Frankfurt am Main: S. Fischer Verlag, 2005, pp. 284-300. 
Dierks, Manfred. “Traumzeit und Verdichtung. Der Einfluß der Psychoanalyse auf Thomas Manns Erzählweise". In Eckhard Heftrich and Helmut Koopmann (eds.). Thomas Mann und Seine Quellen. Festschrift für Hans Wysling. Frankfurt am Main: Vittorio Klostermann Verlag, 1991, pp. 111-37.

Eichner, Hans. "Thomas Mann und die deutsche Romantik”. In Wolfgang Paulsen (ed.). Das Nachleben der Romantik in der modernen deutschen Literatur. Heidelberg: Stiehm Verlag, 1969, pp. 152-73.

Finck, Jean. Thomas Mann und die Psychoanalyse. Paris: Société d'Edition 'Les Belles Lettres', 1973.

Frizen, Werner. “Thomas Mann und das Christentum”. In Helmut Koopmann (ed.). Thomas Mann Handbuch. Frankfurt am Main: S. Fischer Verlag, 2005, pp. 307-26.

Frizen, Werner. Zaubertrank der Metaphysik. Quellenkritische Überlegungen im Umkreis der Schopenhauer-Rezeption Thomas Manns. Frankfurt am Main: Peter Lang Verlag, 1980.

Genette, Gérard. Palimpsests: Literature in the second degree. Nebraska: University of Nebraska Press, 1997.

Gibson, Randall W. The Mystery of Death: Toward a Pacifist Ethic. Cambridge: ProQuest UMI Dissertations Publishing, 2008.

Gremler, Claudia. Fern im dänischen Norden ein Bruder: Thomas Mann und Hermann Bang, eine literarische Spurensuche. Göttingen: Vandenhoeck \& Ruprecht Verlag, 2003.

Grimm, Jacob and Wilhelm. Deutsches Wörterbuch (1854-1961). Trier: Trier Centre for Digital Humanities, 2011. http://woerterbuchnetz.de/DWB/; online resource accessed 19 December 2012. 
Grimm, Jacob and Wilhelm. Kinder- und Hausmärchen, vol. 1. Stuttgart: Philipp Reklam Verlag, 1980.

Hamburger, Käte. Thomas Mann und die Romantik. Eine problemgeschichtliche Studie. H. Hecht (ed.). Neue Forschung. Arbeiten zur Geistesgeschichte der Germanischen und Romanischen Völker, vol. 15. Berlin: Junker \& Dünnhaupt Verlag, 1932.

Healy, Róisín. The Jesuit Specter in Imperial Germany. Thomas Brady and Roger Chickering (eds.). Studies in Central European Histories. Boston: Brill Academic Publishers inc., 2003.

Heinze, Carsten. Identität und Geschichte in Autobiographischen Lebensrekonstruktionen. Jüdische und nicht-jüdische Vergangenheitsbearbeitungen in Ost- und Westdeustschland. Wiesbaden: Verlag für Sozialwissenschaften, 2009.

Herwig, Henriette. "Literaturwissenschaftliche Intertextualitätsforschung im Spannungsfeld konkurrierender Intertextualitätsbegriffe". In Roland Posner (ed.). Zeitschrift für Semiotik, vol. 24. Tübingen: Stauffenburg Verlag, 2002, pp. 163-76.

Hinz, Michael. Verfallsanalyse und Utopie. Nietzsche-Rezeption in Thomas Manns 'Zauberberg' und in Robert Musils 'Der Mann ohne Eigenschaften'. Beiträge zur RobertMusil-Forschung und zur neueren österreichischen Literatur, vol. 13. St. Ingbert: Röhrig Universitätsverlag, 2000.

Hofstätter, Peter R. "Einführung”. In Gustav le Bon. Psychologie der Massen. Stuttgart: Kröner Verlag, 1982, pp. XIII-XXXVIII.

Hutcheon, Linda. A Theory of Parody. The Teachings of Twentieth-Century Art Forms. New York: Methuen, 1985. 
Jens, Inge and Walter. "Die Tagebücher". In Helmut Koopmann (ed.). Thomas Mann Handbuch. Frankfurt am Main: S. Fischer Verlag, 2005, pp. 721-41.

Jens, Inge. “Thomas Mann. Auszeichnung durch Krankheit”. In Thomas Sprecher (ed.). Literatur und Krankheit im Fin-de-Siècle (1890-1914). Thomas-Mann-Studien, vol. 26. Frankfurt am Main: Vittorio Klostermann Verlag, 2000, pp. 233-51.

Jequier, Anne M. Male Infertility: A Clinical Guide. Cambridge: Cambridge University Press, 2011.

Jordan, Sven. Das Organische zwischen Naturwissenschaft und Mystizismus. Thomas Manns 'Zauberberg' aus der Perspektive des Kapitels 'Forschungen' betrachtet. Berlin: Wissenschaftliche Hausarbeit zur Ersten (Wissenschaftlichen) Staatsprüfung für das Amt des Studienrats, 1993.

Joseph, Erkme. Nietzsche im 'Zauberberg'. Thomas-Mann-Studien, vol. 14. Frankfurt am Main: Vittorio Klostermann Verlag, 1996.

Koopmann, Helmut. "Die Lehren des Zauberbergs". In Thomas Sprecher (ed.). Das Zauberberg Symposium. Frankfurt am Main: Vittorio Klostermann Verlag, 1994, pp. 5980 .

Koopmann, Helmut. "Doktor Faustus". In Helmut Koopmann (ed.). Thomas Mann Handbuch. Frankfurt am Main: S. Fischer Verlag, 2005, pp. 445-97.

Koopmann, Helmut. "Philosophischer Roman oder romanhafte Philosophie? Zu Thomas Manns lebensphilosophischer Orientierung in den zwanziger Jahren". In Rudolf Wolff (ed.). Aufsätze zum Zauberberg. Bonn: Bouvier Verlag, 1988, pp. 61-88. 
Koopmann, Helmut. "Schlußwort”. In Thomas Sprecher (ed.). Das Zauberberg Symposium. Thomas-Mann-Studien 11. Frankfurt am Main: Vittorio Klostermann Verlag, 1995, pp. 265-68.

Koopmann, Helmut. “Thomas Mann”. In Hartmut Steinecke (ed.). Deutsche Dichter des 20. Jahrhunderts. Berlin: Erich Schmidt Verlag, 1994, pp. 135-57.

Koopmann, Helmut. “Thomas Mann und Schopenhauer". In Peter Pütz (ed.). Thomas Mann und die Tradition. Frankfurt am Main: Athenäum Verlag, 1971, pp. 180-200.

Koopmann, Helmut. "Vorwort". In Helmut Koopmann (ed.). Thomas Mann Handbuch. Frankfurt am Main: S. Fischer Verlag, 2005, pp. XIII-XV.

Kowalik, Jill Anne. “'Sympathy with Death': Hans Castorp's Nietzschean Resentment”. In The German Quarterly. Hoboken, New Jersey: Wiley-Blackwell, 1985, pp. 27-48.

Kristeva, Julia. Desire in Language: A Semiotic Approach to Literature and Art. Thomas Gora, Alice Jardine and Leon S. Roudiez (transl.). New York: Columbia University Press, 1980 .

Kristeva, Julia. Revolution in Poetic Language. Margaret Waller (trans1.). New York: Columbia University Press, 1984.

Kristiansen, Børge. "Thomas Mann und die Philosophie”. In Helmut Koopmann (ed.). Thomas Mann Handbuch. Frankfurt am Main: S. Fischer Verlag, 2005, pp. 259-83.

Kristiansen, Børge. Thomas Manns Zauberberg und Schopenhauers Metaphysik. Bonn: Bouvier Verlag, 1986.

Kurzke, Hermann. Thomas Mann: Epoche-Werk-Wirkung. München: C.H. Beck Verlag, 1997. 
Lehnert, Herbert. "Thomas Mann und die Literatur seiner Zeit”. In Helmut Koopmann (ed.). Thomas Mann Handbuch. Frankfurt am Main: S. Fischer Verlag, 2005, pp. 137-63.

Maar, Michael. Geister und Kunst: Neuigkeiten aus dem Zauberberg. Frankfurt am Main: S. Fischer Verlag, 1997.

Mayer, Hans. “Thomas Manns 'Zauberberg' als Roman der Weimarer Republik”. In Hans Mayer. Ansichten von Deutschland. Bürgerliches Heldenlesen. Frankfurt am Main: Suhrkamp Verlag, 1988, pp. 89-113.

McCarthy, O. R. "The Key to the Sanatoria”. In Journal of the Royal Society of Medicine, vol. 94, no. 8. London: Sage Publications, 2001, pp. 413-17.

McGrath, Alistair E. Christian Theology: An Introduction. Chichester: Wiley-Blackwell, 2011.

Neubauer, John. Bifocal vision: Novalis' philosophy of nature and disease. Chapel Hill: University of North Carolina Press, 1971.

Neubauer, John. "Dr John Brown and early German Romanticism”. In Journal of the History of Ideas, vol. 28, no. 3. Pennsylvania: University of Pennsylvania Press, 1967, pp. 367-82.

Noble, Cecil A. Krankheit, Verbrechen und künstlerisches Schaffen bei Thomas Mann. Europäische Hochschulschriften. Bern: Verlag Herbert Lang \& Cie AG, 1970.

Petersen, Eiko E. Infektionen in Gynäkologie und Geburtshilfe: Lehrbuch und Atlas. Stuttgart: Georg Thieme Verlag, 2003. 
Pfister, Manfred. "Konzepte der Intertextualität”. In Ulrich Broich and Manfred Pfister (eds.). Intertextualität. Formen, Funktionen, anglistische Fallstudien. Tübingen: Max Niemeyer Verlag, 1985, pp. 1-30.

Pütz, Peter. "Krankheit als Stimulans des Lebens. Nietzsche auf dem Zauberberg”. In Thomas Sprecher (ed.). Das Zauberberg Symposium. Thomas-Mann-Studien, vol. 11. Frankfurt am Main: Vittorio Klostermann Verlag, 1995, pp. 249-64.

Pütz, Peter. Kunst und Künstlerexistenz bei Nietzsche und Thomas Mann. Bonn: Bouvier Verlag, 1963.

Pütz, Peter. “Thomas Mann und Nietzsche”. In Peter Pütz (ed.). Thomas Mann und die Tradition. Frankfurt am Main: Athenäum Verlag, 1971, pp. 226-49.

Reed, Terence J. “Thomas Mann und die literarische Tradition”. In Helmut Koopmann (ed.). Thomas Mann Handbuch. Frankfurt am Main: S. Fischer Verlag, 2005, pp. 95-136.

Reents, Edo. Zu Thomas Manns Schopenhauer-Rezeption. Eckhard Heftrich and Hermann Kurzke (eds.). Studien zur Literatur- und Kulturgeschichte, vol. 12. Würzburg: Königshausen \& Neumann Verlag, 1998.

Reich-Ranicki, Marcel. Thomas Mann und die Seinen. Stuttgart: Deutsche Verlags-Anstalt, 1988.

Riffaterre, Michael. "Compulsory reader response: the intertextual drive". In Michael Worton and Judith Still (eds.). Intertextuality: Theories and Practices. Manchester: Manchester University Press, 1990, pp. 56-78.

Rusterholz, Peter. "Vom 'Werk' zu Intertextualität der Stoffe: Friedrich Dürrenmatts Wandlung". In Roland Posner (ed.). Zeitschrift für Semiotik, vol. 24. Tübingen: Stauffenburg Verlag, 2002, pp. 295-305. 
Saariluoma, Lisa. Nietzsche als Roman: Über die Sinnkonstituierung in Thomas Manns 'Doktor Faustus'. Tübingen: Max Niemeyer Verlag, 1996.

Sauereßig, Heinz. "Die Tuberkulose als Paradigma des Lebensgefühls". In Die Medizinische Welt, vol. 33, no. 12. Stuttgart: Schattauer Verlag, 1982, pp. 428-34.

Schader, Brigitte. Schwindsucht - Zur Darstellung einer tödlichen Krankheit in der deutschen Literatur vom poetischen Realismus bis zur Moderne. Frankfurt am Main: Peter Lang Verlag, 1987.

Schößler, Franziska. "Markierte Zitate und Kultur als Intertext: Varianten der Intertextualität in Thomas Manns Roman Königliche Hoheit”. In Roland Posner (ed.). Zeitschrift für Semiotik, vol. 24. Tübingen: Stauffenburg Verlag, 2002, pp. 199-212.

Seidel, George J. Knowledge as Sexual Metaphor. Susquehann: Susquehann University Press, 2000.

Smikalla, Karl. Die Stellung Thomas Manns zur Romantik. Würzburg: Dissertation JuliusMaximilians-Universität, 1953.

Stocker, Peter. Theorie der intertextuellen Lektüre: Modelle und Fallstudien. München: Ferdinand Schöningh Verlag, 1998.

Tsouyopoulos, Nelly. “The Influence of John Brown's Ideas in Germany”. In Medical History, vol. 32, supplement no. 8. Cambridge: Cambridge University Press, 1988, pp. 6374.

Urban, Bernd. "Einleitung". In Sigmund Freud. Der Wahn und die Träume in W. Jensens 'Gradiva'. Frankfurt am Main: S. Fischer Verlag, 2003, pp. 7-44. 
Watson, Peter. The German Genius. London: Simon \& Schuster UK Ltd, 2011.

Weigand, Hermann. The Magic Mountain. A Study of Thomas Mann's Novel Der Zauberberg. Chapel Hill, North Carolina: The University of North Carolina Press, 1965.

Weiniger, Otto. Geschlecht und Charakter: ein prinzipielle Untersuchung. München: Matthes \& Seitz Verlag, 1980.

Wenzel, Georg. Novalis in den Anschauungen von Ricarda Huch, Thomas Mann und Hermann Hesse. Texte aus dem Novalis-Schloß, vol. 2. Schloß Oberwiederstedt: Janos Stekovics Verlag, 1997.

Widdess-Walsch, Peter, Mostacci, Barbara, Tinuper, Paolo, and Devinsky, Orrin. "Psychogenic nonepileptic seizures". In Stefan Hermann and William H. Theodore (eds.). Epilepsy part I. Handbook of Clinical Neurology, vol. 107. Amsterdam: Elsevier BV, 2012, pp. 277-95.

Windisch-Laube, Walter. "Thomas Mann und die Musik”. In Helmut Koopmann (ed.). Thomas Mann Handbuch. Frankfurt am Main: S. Fischer Verlag, 2005, pp. 327-42.

Wolff, Katja. "Dem Tod keine Herrschaft einräumen - Peeperkorn als Humanist.” In Rudolf Wolff (ed.). Aufsätze zum Zauberberg. Bonn: Bouvier Verlag, 1988, pp. 91-113.

Wysling, Hans. "Der Zauberberg - als Zauberberg”. In T. Sprecher (ed.). Der Zauberberg Symposium. Frankfurt am Main: Vittorio Klostermann Verlag, 1994, pp. 43-58.

Wysling, Hans. "Der Zauberberg”. In Helmut Koopmann (ed.). Thomas Mann Handbuch. Frankfurt am Main: S. Fischer Verlag, 2005, pp. 397-422.

Wysling, Hans. "Schopenhauer-Leser Thomas Mann”. In Schopenhauer Jahrbuch, vol. 64. Würzburg: Königshausen \& Neumann Verlag, 1983, pp. 61-79. 
Wysling, Hans. "Thomas Manns Rezeption der Psychoanalyse”. In Benjamin Bennett (ed.). Probleme der Moderne. Studien zur deutschen Literatur von Nietzsche bis Brecht. Festschrift für Walter Sokel. Tübingen: Max Niemeyer Verlag, 1983, pp. 201-22.

Zentner, Marcel. Die Flucht ins Vergessen: Die Anfänge der Psychoanalyse Freuds bei Schopenhauer. Darmstadt: Wissenschaftliche Buchgesellschaft, 1995. 